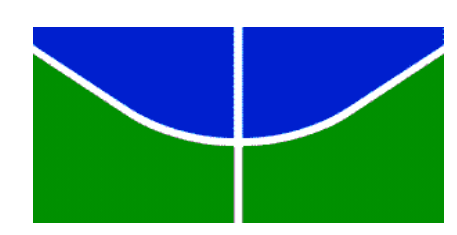

UNIVERSIDADE DE BRASÍLIA

INSTITUTO DE CIÊNCIAS SOCIAIS

DEPARTAMENTO DE SOCIOLOGIA

WEDERSON SANTOS

OS ESQUECIDOS:

FAMILISMO E ASSISTÊNCIA PÚBLICA NA

INIMPUTABILIDADE POR DOENÇA E DEFICIÊNCIA

MENTAL NO BRASIL

BRASÍLIA-DF 
WEDERSON SANTOS

OS ESQUECIDOS:

\section{FAMILISMO E ASSISTÊNCIA PÚBLICA NA INIMPUTABILIDADE POR DOENÇA E DEFICIÊNCIA MENTAL NO BRASIL}

Tese de Doutorado apresentada à Universidade de Brasília como um dos pré-requisitos para obtenção do título de doutor em Sociologia.

Orientadora: Maria Stela Grossi Porto

BRASÍLIA-DF

2014 


\section{WEDERSON SANTOS}

\section{OS ESQUECIDOS: FAMILISMO E ASSISTÊNCIA PÚBLICA NA INIMPUTABILIDADE POR DOENÇA E DEFICIÊNCIA MENTAL NO BRASIL}

Tese de Doutorado apresentada como exigência parcial para a obtenção do título de doutor em Sociologia à comissão julgadora da Universidade de Brasília.

Aprovada em 21 de janeiro de 2015.

BANCA EXAMINADORA

Vicente de Paula Faleiros

Universidade Católica de Brasília

Debora Diniz

Universidade de Brasília

Eurico A. G. Cursino dos Santos

Universidade de Brasília

Cristina Zackseski

Universidade de Brasília 
Dados Internacionais de Catalogação na Publicação (CIP)

Bibliotecário Responsável: Illy Guimarães B. Batista (CRB/DF 2498)

\section{Santos, Wederson.}

Os esquecidos: familismo e assistência pública na inimputabilidade por doença e deficiência mental no Brasil / Wederson Santos. - 2014.

$280 \mathrm{f}$. : il.

\section{Orientadora: Maria Stela Grossi Porto}

Tese (doutorado) - Universidade de Brasília, Departamento de Sociologia, 2014.

1. Saúde mental - Brasil. 2. Assistência social - Brasil. 3. Manicômios judiciários - Brasil. 4. Medidas de segurança - Brasil. 5. Familismo - Brasil. 6. Políticas sociais - Brasil. I. Título.

CDU 616.89:364(81) 
Dedico às famílias dos esquecidos. 


\section{AGRADECIMENTOS}

Agradeço, inicialmente, a toda equipe de pesquisadores da Anis: Instituto de Bioética, Direitos Humanos e Gênero que realizou no ano de 2011 o estudo censitário nos hospitais de custódia e tratamento psiquiátrico do país. Agradeço a Fabiana Paranhos, João Neves, Mayara Araújo, Sandra Costa, Lina Vilela, Miryam Mastrella, Júlia de Albuquerque, Helena Lancelloti, Bárbara Silva, Luciana Stoimenoff, Cássia Castro, Leonardo Lage, Janaína Penalva, além de Marcelo Medeiros, que compuseram a equipe da qual fiz parte e tornou possível realizar a fotografia inédita desta população. Em especial, agradeço à professora Debora Diniz pela dedicada contribuição ao meu processo de formação enquanto pesquisador na área de direitos humanos que, com o seu olhar dedicado e treinado para descortinar as desigualdades do mundo, fez-me acreditar na pesquisa científica como um importante instrumento de luta para superação das injustiças. Agradeço também pela confiança de Debora quando me convidou para ser o supervisor do estudo censitário. Agradeço ao Juiz Bruno Ribeiro, juiz da Vara de Execuções Penais do Tribunal de Justiça do Distrito Federal e Territórios (VEP-TJDFT) e à Raquel Manzini, chefe da Seção Psicossocial da VEP-TJDFT, pela autorização para realização do estudo de caso das medidas de segurança em fase de desinternação no Distrito Federal em 2013. Por meio do agradecimento à Raquel, agradeço a todos os profissionais da VEP que contribuíram com a realização do estudo de caso. Agradeço a assistente social Juliana Lima, da Secretaria de Saúde do Distrito Federal, pela enorme gentileza em facilitar o acesso aos dados relativos ao Programa de Volta para Casa no DF. Agradeço aos queridos amigos Paulo Henrique Pereira, Gislene Vieira, Jamila Zgiet e Lívia Barbosa que, em meio às conversas sobre a vida e sobre nossos sonhos, sempre discutíamos o processo de elaboração dessa tese. Agradeço aos meus queridos alunos do curso de Serviço Social das Faculdades Projeção de Brasília e FACISA de Unaí-MG, pelas constantes reflexões acerca das políticas sociais que me inspiravam. Agradeço aos colegas assistentes sociais do Instituto Nacional do Seguro Social - INSS, em especial às minhas colegas da Divisão do Serviço Social do INSS que, pelos nossos diálogos cotidianos sobre seguridade social, faziam-me ampliar o olhar sobre a temática dessa tese. Agradeço a minha orientadora Maria Stela Grossi Porto que, de forma paciente e dedicada, fazia-me refletir cada momento sobre meu objeto de análise, coleta de dados, escrita e elaboração dos resultados que sustentam esse estudo. Por fim, agradeço aos professores Eurico dos Santos, Cristina Zackseski, Debora Diniz e Vicente Faleiros que participam da banca de defesa da tese. 
“Gostaria que pudéssemos trancar para sempre a pobreza, ao invés desses homens." Luis Buñuel [1950] 


\section{RESUMO}

Esta tese é um estudo com métodos quantitativos e qualitativos de coleta e análise de dados sobre o processo de desinternação dos indivíduos em medidas de segurança que já cumpriram os critérios psiquiátricos e penais para o retorno à liberdade. Medida de segurança é um dispositivo criado no Código Penal de 1940 para garantir tratamento psiquiátrico obrigatório aos indivíduos com doença ou deficiência mental que tenham sido diagnosticados, no momento do crime, como incapazes de entender a ilicitude do ato ou de determinar-se de acordo com essa incapacidade. As medidas de segurança podem ser de tratamento ambulatorial ou de internação; sendo estas últimas executadas em restrição de liberdade e ambas acompanhadas pelos Estabelecimentos de Custódia e Tratamento Psiquiátrico (ECTPs). Em 2011, havia 26 ECTPs no Brasil. De acordo com a publicação A custódia e o tratamento psiquiátrico no Brasil - Censo 201, havia 2.956 indivíduos em medidas de segurança no país em 2011 nos 26 ECTP. Desses, ao menos 25\% (741) não deveriam estar internados por já estarem com a periculosidade cessada, por terem sentença de desinternação, medida de segurança extinta ou internação sem processo judicial. Esses $25 \%$ dos indivíduos em medidas de segurança que já cumpriram os critérios para a desinternação, mas continuam em restrição de liberdade indevida, são denominados nesta tese de os esquecidos dos manicômios judiciários brasileiros. Foi feita uma análise das políticas de saúde mental e de assistência social para avaliar como elas se inter-relacionam com a política de segurança pública no momento da desinternação dos indivíduos em medidas de segurança. A hipótese que guiou a análise empírica nessa tese foi a de que as políticas de assistência social e de saúde mental são estruturadas tendo a responsabilidade de provisão de bem-estar dos indivíduos compartilhada entre o Estado e as famílias. Como os indivíduos em medidas de segurança, principalmente na fase da desinternação, têm relações complexas com suas famílias e muitos deles sem relações com os membros familiares, o fato de as políticas prescindirem do compartilhamento de responsabilidade com as famílias na provisão de bemestar dos indivíduos pode impedir a proteção social deles na fase de desinternação, causando a restrição de liberdade indevida. Foi investigado se há presença do familismo nas políticas de saúde mental e de assistência. Familismo é uma característica das políticas sociais em que a família é vista como um agente que oferta bens e serviços para o bem-estar dos indivíduos, assumindo grande parte das funções das políticas públicas que deveriam ser de responsabilidade do Estado. Foi delineado que, no caso das políticas de saúde mental e de assistência social no Brasil, o familismo manifesta-se de três modos diferentes: o familismo por compartilhamento de responsabilidades, o familismo por transferência do Estado às famílias e o familismo por omissão do Estado. No caso das medidas de segurança em fase de desinternação, esses três tipos de familismo estão presentes nas políticas de assistência social e de saúde mental, sendo capazes de explicar o surgimento dos esquecidos no interior dos manicômios judiciários brasileiros.

PALAVRAS-CHAVES: medidas de segurança; saúde mental; crimes; manicômios judiciários; assistência social; familismo; políticas sociais. 


\section{RESUMEN}

Esta tesis es un estudio, con métodos cuantitativos y cualitativos de recolección y análisis de datos, sobre el proceso de desinternación de individuos con medidas de seguridad que ya cumplieron los criterios psiquiátricos y penales para recuperar la libertad. Medida de seguridad es un dispositivo creado por el Código Penal brasileño de 1940 destinado a garantizar el tratamiento psiquiátrico obligatorio a individuos que padecen una enfermedad o discapacidad mental y que hubieran sido diagnosticados al momento de crimen como incapaces para comprender la magnitud de sus actos ilícitos o para auto determinarse en función de dicha incapacidad. Las medidas de seguridad pueden ser de tratamiento ambulatorio y de internación; siendo estás últimas ejecutadas con restricción de libertad y ambas acompañadas por los Establecimientos de Custodia y Tratamiento Psiquiátrico (FCTRs). En 2011, habia 26 ECTPs en Brasil. De acuerdo con la publicación "A custódia e o tratamento psiquiátrico no Brasil - Censo 2011", había 2.956 individuos con medidas de seguridad en el país en 2011 en los 26 ECTP existentes. De todos ellos, al menos 25\% (741) no deberían estar internados dado que su peligrosidad ya cesó sea porque sobre ellos recayó sentencia de desinternación, porque la medida seguridad se extinguió o porque se ordenó la internación sin proceso judicial previo. Dicho $25 \%$ de individuos con medidas de seguridad que ya cumplieron los criterios de desinternación pero que continúan con su libertad restringida en forma indebida, son denominados en esta tesis como los olvidados de los manicomios judiciales brasileños. Fue realizado un análisis de políticas de salud mental y de asistencia social para evaluar como las mismas se relacionan con la política de seguridad pública llevada a cabo al momento de la desinternación de los individuos con medidas de seguridad. La hipótesis que guió el análisis empírico de esta tesis fue la siguiente: las políticas de asistencia social y de salud mental son estructuradas teniendo la rea de que as políticas de asistencia social e de salud mental son estructuradas para ser responsables de la proveer bienestar a los individuos compartida entre Estado y las familias. Como los individuos con medidas de seguridad, principalmente en la fase de desinternación, tienen relaciones complejas con sus famílias y muchos de ellos non si relaciones con los miembros familiares, el hecho de que las políticas prescindan de compartir la responsabilidad con las familias, en la provisión de bien estar de los individuos, puede impedir la protección social de estos en la fase de desinternación, causando la restricción de libertad en forma indebida. Fue investigado se hay presencia del familismo em las políticas de salud mental y de asistencia. Familismo es uma característica de las políticas sociales en que la família es vista como un agente que oferta bienes y servicios para el bienestar de los individuos, asumiendo gran parte de las funciones de las políticas públicas que deberían ser de responsabilidad del Estado. Fue deliniado que, en el caso de las políticas de salud mental y de asistencia social en Brasil, el familismo se manifesta de tres modos diferentes: el familismo por compartir de responsabilidade entre Estado y llas familias, el familismo por transferencia del Estado a las familias y el familismo por omisión del Estado. En el caso de las medidas de seguridad en fase de desinternación, estos tres tipos de familismo están presentes en las politicas de asistencia social y el de la salud mentale y son capaces de explicar el surgimiento de los olvidados en el interior de los manicomios judiciales brasileños.

PALABRAS-CLAVES: medidas de seguridad; salud mental; crimenes; manicomios judiciales; asistencia social; familismo; políticas sociales. 


\begin{abstract}
This thesis is a study of both quantitative and qualitative methods of data collection and analysis on the suspension of internment process of individuals in security measures that have already met the psychiatric and criminal criteria for returning to freedom. Security measure is a device created in the 1940 Brazilian Penal Code to ensure compulsory psychiatric treatment to individuals with mental illness or disability who have been diagnosed, at the time of the crime, as unable to understand the wrongfulness of the act or determined in accordance with this disability. Security measures can be outpatient treatment and/or hospitalization; the latter being performed on restriction of freedom, both being accompanied and executed by the Custody and Psychiatric Treatment Institutions (ECTPs). According to the 2012 publication The custody and psychiatric treatment in Brazil - Census 2011, there were 2,956 individuals under security measures in the country in 2011 within the 26 existing ECTPs. At least $25 \%$ of those (741) should not be admitted because they are already danger-free, or have a suspension of internment sentence, extinct security measure or detention without judicial process. These $25 \%$ of individuals in security measures that have already met the criteria for suspension but are still in undue freedom restriction, are called in this thesis the forgotten of Brazilian forensic psychiatric hospitals. An analysis of mental health policies and social assistance was done to assess how they interrelate with the public security policy at the time of suspension of internment of individuals in safety measures. The hypothesis that guided the empirical analysis in this thesis was that both welfare and mental health policies are structured according to welfare provision of shared responsibility of individuals between the State and families. As individuals in security measures, especially at the stage of suspension of internment, have complex relationships with their families and many of them have no relationships with family members whatsoever, sharing responsibility policies might prevent their social protection in the suspension of internment phase, causing undue freedom restriction. We investigated whether there was presence of familism in mental health and assistance policies. Familism is a feature of social policies in which the family is seen as an agent that offers goods and services for the well-being of individuals, assuming most of the functions of public policies that should be of State responsibility. It was outlined that, in the case of mental health policies and social welfare in Brazil, familism manifests itself in three different ways: sharing familism, transfer familism and default familism. In the case of security measures in suspension of internment, these three types of familism are present and are able to explain the emergence of the forgotten of Brazilian forensic psychiatric hospitals.
\end{abstract}

KEYWORDS: security measures; mental health; crimes; forensic psychiatric hospitals; social assistance; familism; social policies. 


\section{RÉSUMÉ}

Cette étude collecte et analyse des donnés sur la suspension du processus d'internement, avec mesure de sécurité, (medida de segurança) de personnes qui ont déjà satisfait aux critères psychiatriques et pénaux pour un retour à la liberté. Cet outil permettra de collecter et d'analyser les donnés du processus de désinstitutionnalisation des personnes qui ont été mises en mesure de sécurité. "Mesure de sécurité » est un dispositif créé par le Code pénal de 1940 pour assurer un traitement psychiatrique obligatoire à des personnes atteintes de maladie mentale ou de handicap et qui ont été diagnostiqués comme incapables de comprendre l'illéicité de leur acte ou déterminés par ce handicap au moment du crime. Les mesures de sécurité peuvent être un traitement ambulatoire ou hospitalier ; ce dernier est effectué avec ou sans restriction de liberté par les institutions de dépôt et de traitement psychiatrique (Les ECPTs). En 2011, il y avait 26 ECTPs au Brésil. Selon la publication « La garde et le traitement psychiatrique au Brésil - Recensement de 2011 à 2012 », il y avait 2956 personnes sous le régime «mesures de sécurité » dans les 26 ECPTs du pays en 2011. Parmi ceux-ci, au moins $25 \%$ (741) ne sont plus obligés d'être retenus. Ce sont les cas où ont cessé la dangerosité, la peine d'internement, la mesure de sécurité et la détention sans procédure judiciaire. Ces personnes sont encore dans les mesures de sécurité mais ont déjà atteint les critères de suspension. Par contre, elles sont toujours détenues. Ces personnes sont appelés dans cette thèse de les oubliés des hôpitaux psychiatriques médico-légaux Brésiliens. Une analyse des politiques de santé mentale et d'assistance sociale afin d'évaluer la façon dont ils interagissent avec la politique de la sécurité publique au moment de la suspension de l'internement des personnes dans des mesures de sécurité a été faite. L'hypothèse qui a guidé l'analyse empirique dans cette thèse, c'est que la responsabilité des politiques sociales de la santé mentale est partagée, conformément à la disposition du bien être, entre responsabilité de l'État et des familles. Les personnes détenues par mesure de sécurité, surtout les individus en «suspension d'internement», ont des relations complexes avec leur famille et beaucoup d'entre eux ont rompu es relations familiales. L'absence du partage avec les familles de la responsabilité des politiques pour ces individus en suspension de la phase d'internement, au niveau de la protection sociale, peut empêcher leur protection sociale. Nous avons étudié s'il y avait présence de familialisme dans les politiques de santé et d'assistance. Familialisme est une caractéristique des politiques sociales dans lesquelles la famille est considérée comme un agent qui offre des biens et services pour le bien-être des individus, en supposant que la plupart des fonctions des politiques publiques devraient être de la responsabilité de l'État. Il a été souligné que dans les cas des politiques de santé mentale et de bien-être social au Brésil, cela ne fait que trois formes : ou bien 1) familalisme, 2) familalisme par transfert, 3) familalisme par omission. Dans le cas des mesures de sécurité en suspension d'internement, ces trois types de familialisme sont présents et sont en mesure d'expliquer l'émergence des oubliés à l'intérieur des hôpitaux psychiatriques médicaux légaux brésiliens.

MOTS-CLÉ: mesure de securité; santé mentale; crimes ; institutions judiciaires ; assistance social (publique) ; familisme ; politiques sociales. 


\section{LISTA DE SIGLAS}

ADI Ação Direta de Inconstitucionalidade ATP. Ala de Tratamento Psiquiátrico

BIRD. Banco Interamericano de Desenvolvimento

BPC. Benefício de Prestação Continuada da Assistência Social

CAPs Caixas de Aposentadorias e Pensões

CAPS Centro de Atenção Psicossocial

CNPCP. .Conselho Nacional de Política Criminal e Penitenciária

CRAS Centro de Referência em Assistência Social

CREAS Centros de Referência Especializados em Assistência Social ECA Estatuto da Criança e do Adolescente ECTP. Estabelecimento de Custódia e Tratamento Psiquiátrico EMAD. ..Equipes Multiprofissionais de Atenção Domiciliar

FMI Fundo Monetário Internacional FUNABEM Fundação Nacional do Menor

IAPs. Institutos de Aposentadorias e Pensões

HCTP. Hospital de Custódia e Tratamento Psiquiátrico

IBGE Instituto Brasileiro de Geografia e Estatística

IDH. Índice de Desenvolvimento Humano

INSS Instituto Nacional do Seguro Social IPEA Instituto de Pesquisa Econômica Aplicada

LBA Legião Brasileira de Assistência LOAS Lei Orgânica da Assistência Social LOS. Lei Orgânica da Saúde MDS Ministério do Desenvolvimento Social e Combate à Fome NAF. Núcleo de Atendimento Familiar

PAIF. Serviços de Atenção Integral à Família

PAILI. Programa de Atenção Integral ao Louco Infrator PAI-PJ .Programa de Atenção Integral ao Paciente Judiciário PBF. Programa Bolsa-Família PETI Programa de Erradicação do Trabalho Infantil PNAS Política Nacional de Assistência Social 
PNAD

Pesquisa Nacional por Amostra de Domicílios

PND I

Plano Nacional de Desenvolvimento I

PRONATEC. Programa Nacional de Acesso ao Ensino Técnico e Emprego

RMV. Renda Mensal Vitalícia

SAD. Serviço de Atenção Domiciliar

SRT. Serviços Residenciais Terapêuticos

SNAS Secretaria Nacional de Assistência Social

SUDS Sistema Unificado e Descentralizado de Saúde

SUAS Sistema Único de Assistência Social SUS Sistema Único de Saúde

STF. Supremo Tribunal Federal

TJDFT Tribunal de Justiça do Distrito Federal e Territórios

VEP. Vara de Execuções Penais 


\section{LISTA DE TABELAS}

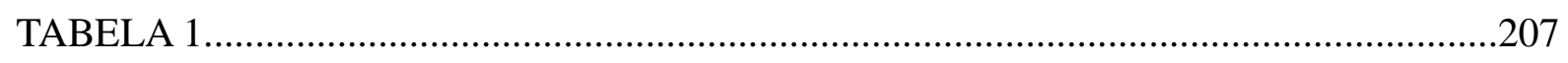

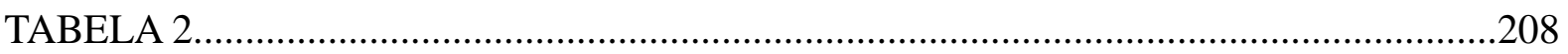

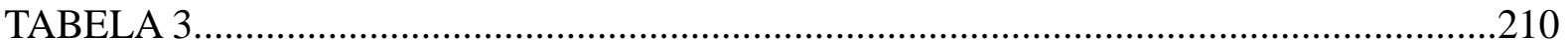

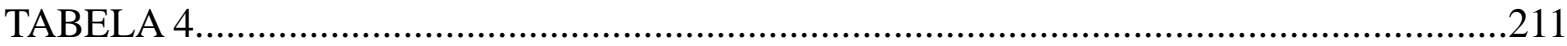

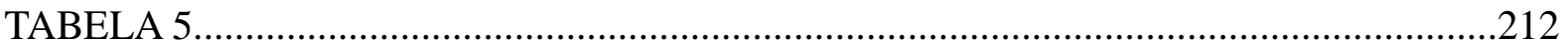

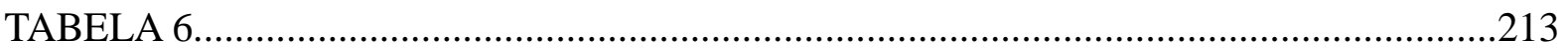

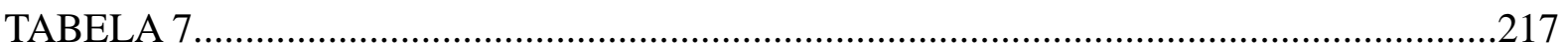

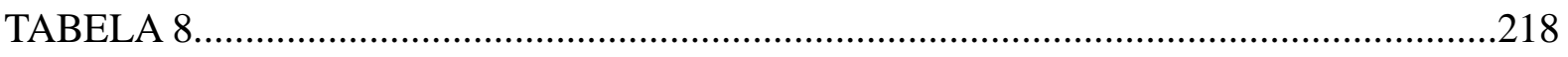

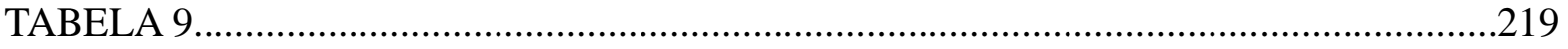

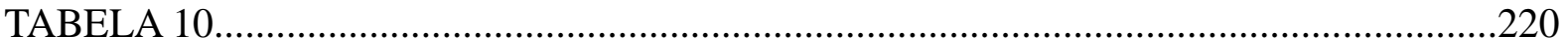

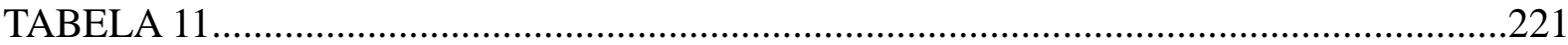

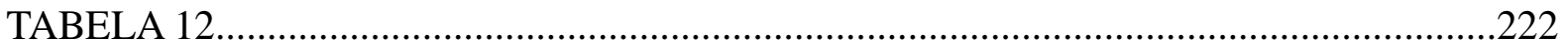

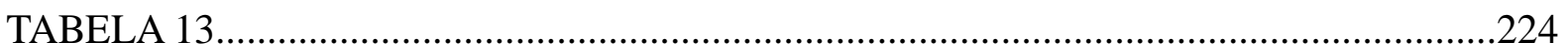

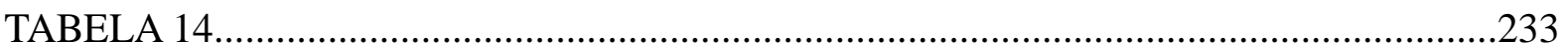

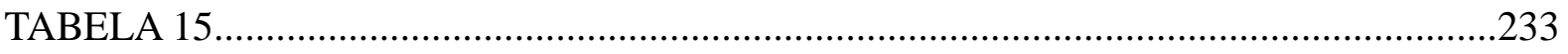

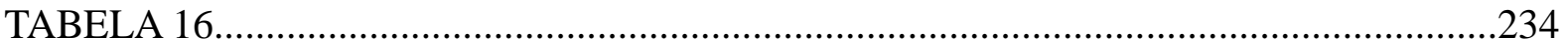

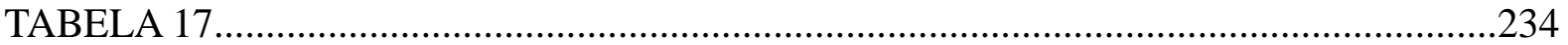

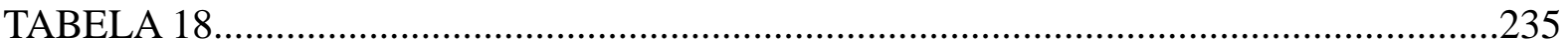

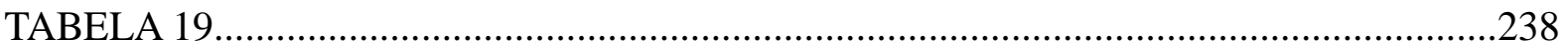

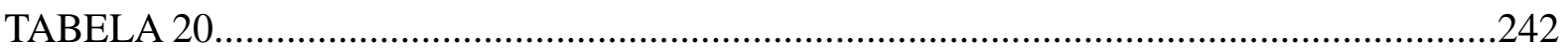

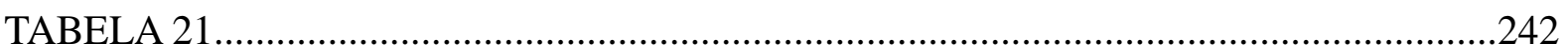

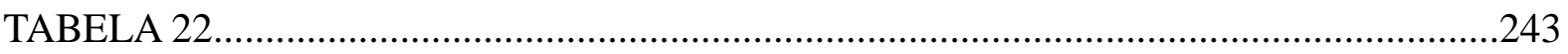

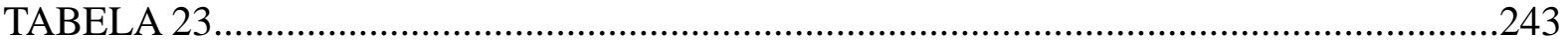

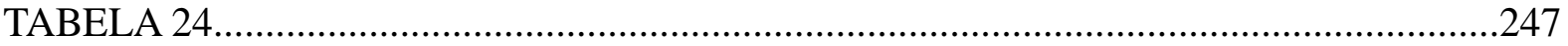




\section{SUMÁRIO}

INTRODUÇÃO

1 OS ESQUECIDOS E O FAMILISMO NAS POLÍTICAS SOCIAIS: DA TUTELA DA ASSISTÊNCIA À CIDADANIA INCONCLUSA.

1.1 Ordenamento familiar e restrição de liberdade: a responsabilidade do Estado compartilhada com as famílias na assistência....

1.1.1 Disciplinas, família e instrumentalização dos membros familiares para o capitalismo.

1.1.2 Liberdade, tutela e cidadania na loucura: o papel da assistência e da saúde mental.

1.2 Governamentalidade e dispositivos de segurança: o espírito do familismo que vai da segurança pública à assistência.

1.3 Estado social no Brasil: a cidadania inconclusa e o papel do Estado no bem-estar social a partir de 1988.

2 PROCEDIMENTOS METODOLÓGICOS: ANÁlise DE POLÍTICA PÚBLICA, GENEALOGIA E ESTUDO DE CASO.

2.1 Fases da pesquisa: análise de política pública e genealogia, dados quantitativos e

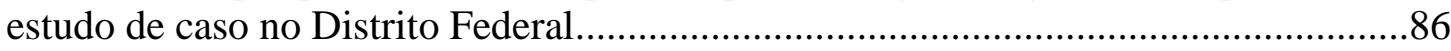

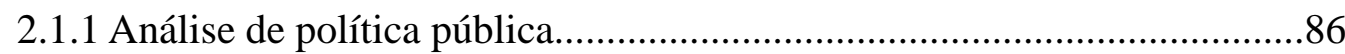

2.1.2 Análise do estudo censitário dos manicômios judiciais...........................89

2.1.3 Estudo de caso no Distrito Federal.........................................................90

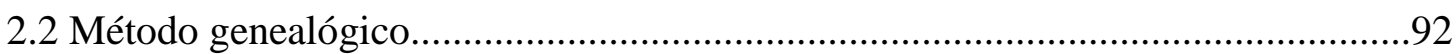

2.3 Análise documental e teoria fundamentada nos dados......................................99

3 FAMILISMO NA ASSISTÊNCIA SOCIAL: UMA GENEALOGIA DAS CONTRADIÇÕES DA ASSISTENCIA COMO POLÍTICA DE SEGURIDADE

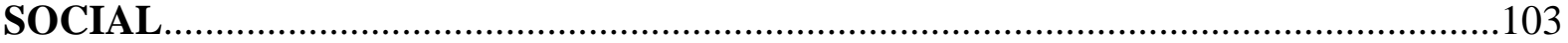

3.1 Entre o discurso das necessidades e a promoção da autonomia: qual o papel da assistência social?.

3.1.1 Assistência como proteção da dignidade: lampejos iluministas em práticas tradicionais................................................................................110

3.2 Assistência, caridade e tutela no Brasil: a genealogia da cidadania pré-fabricada na República inacabada.

3.2.1 Entre as práticas privadas, as necessidades de todos e o papel do Estadopolícia: caridade como paradigma.

3.2.2 Da exclusividade da caridade para a proteção ao trabalho: proteção social como sinônimo de direitos trabalhistas no Brasil do século $\mathrm{XX}$ 121

3.3 Assistência e tutela: pobreza individual versus pobreza familiar na política de assistência social a partir dos anos 1990.

3.3.1 A proteção das famílias no ordenamento político e jurídico préConstituição de 1988

3.3.2 Proteção às crianças, aos idosos e às pessoas com deficiência na Constituição de 1988: o familismo por meio do critério de pobreza familiar e o 
familismo do tipo compartilhamento.

3.4 BPC, Bolsa-Família e Serviço de Atenção Integral à Família (PAIF) nos anos 2000: do ocaso e da tutela ao familismo do tipo transferência e do tipo omissão.

3.5 A assistência social torna-se direito de seguridade social por meio do familismo: o circuito familista.

4 A POLÍtica de SAÚde MENTAL E O FAMILISMO: DA REFORMA PSIQUiÁTRICA AO CIRCUITO FAMILISTA NA SAÚDE MENTAL A PARTIR DOS ANOS 2000

4.1 O nascimento dos asilos: a questão da loucura como caso de polícia e de tutela asilar.

4.2 Assistência como filantropia e punição como assistência: paradoxos nas definições da razão de Estado brasileiro no século XX.

4.3 Acesso universal à saúde e a reforma psiquiátrica: o paradigma da cidadania.

4.4 Lei 10.216 e familismo do tipo transferência: a relação perfeita na política social incompleta.

4.5 Experiências das medidas de segurança em liberdade: os casos de Minas Gerais e Goiás e os limites pelo familismo

4.6 Familismo na saúde mental: o circuito familista e os desafios para a desinternação.

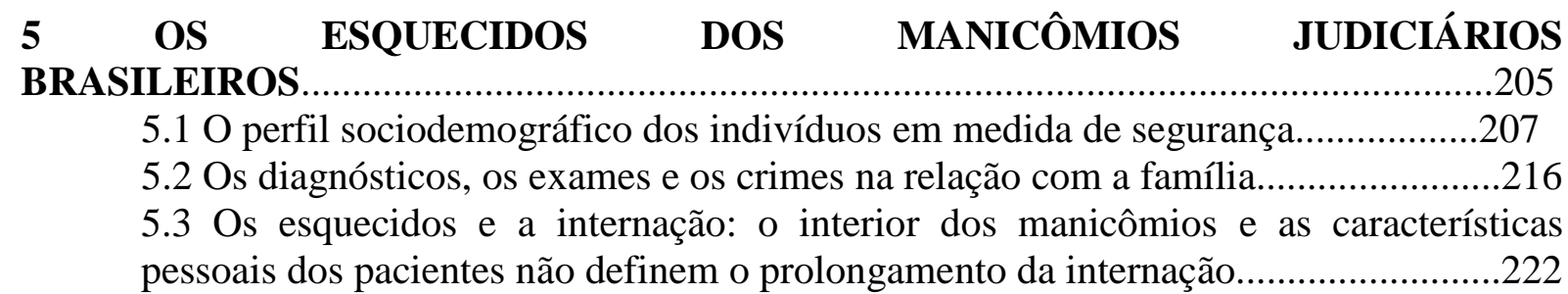

6 ESTUDO DE CASO NO DISTRITO FEDERAL: A EXPRESSÃO DO FAMILISMO NA ASSISTÊNCIA PÚBLICA NA FASE DE

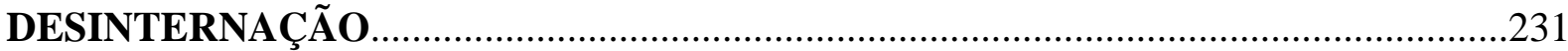

6.1 Características dos indivíduos em desinternação na ATP-DF...............................232

6.2 Extensão dos tempos de internação e itinerário da desinternação..........................244

6.3 Moradia, proteção social e vínculo com a Justiça: as barreiras para a

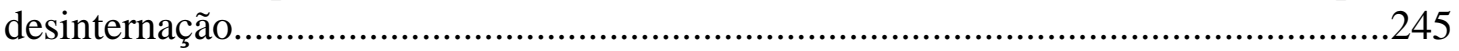

6.4 Políticas sociais e desinternação nas medidas de segurança: o familismo como dispositivo

CONSIDERAÇÕES FINAIS. 254

\section{REFERÊNCIAS BIBLIOGRÁFICAS}

\section{APÊNDICES}




\section{INTRODUÇÃO}

Em 1950, o já famoso cineasta espanhol Luis Buñuel lançou o filme Os esquecidos, abalando o cinema surrealista praticado até então. Laureado com o Prêmio do Festival de Cannes em 1951, o filme é um misto de cinema realista e dramático e tem teor de documentário, na medida em que se baseia em fatos reais e em que conta em sua abertura com uma contextualização a respeito das crianças pobres que moram nas ruas do mundo. A proposta crítica do filme guarda lucidez antecipatória de várias análises acadêmicas que se desenvolveriam nos anos 1960 e 1970 a respeito da relação aparentemente paradoxal, mas inteligível, entre desigualdades sociais, família e instituições disciplinares, como as obras de Michel Foucault, Robert Castel e Jacques Donzelot. Os esquecidos são os meninos delinquentes das ruas da Cidade do México que, ora podem ser vistos por suas existências singulares, ora podem ser resultado de uma engenharia social que se desenvolve a partir da pobreza na relação contraditória com a influência coercitiva de instituições como escola, abrigos correcionais, fábricas e famílias que produzem os destinos incertos desses meninos pobres.

A substantivação da palavra "esquecidos" para o título da obra de Buñuel não pode ser menosprezada. Os "esquecidos" do título se referem aos meninos que foram parar nas ruas por abandono direto de seus familiares. O menino apelidado de "Ojitos", que chora por ter se perdido de seu pai durante um passeio pelo conturbado centro da cidade, aos poucos vai sendo alertado pelos novos companheiros que fora abandonado ali, como tantos outros, de propósito pelo pai. A situação de abandono dos filhos no centro da cidade se dá pela batalha dos pais diante das agruras da pobreza, da família numerosa e da impossibilidade de garantir o sustento de tantos filhos em período de grave pobreza no México. Mas as crianças que fazem da rua seu lar não chegaram a essa situação apenas pelos pais que as abandonaram. Elas também são resultado das relações com suas famílias, dos conflitos do afeto que, em alguns casos, obrigam-nas ainda pequenas a trabalhar para sobreviver - trabalho de rua que, na maioria das vezes, se transforma em pequenas delinquências. De forma secundária, os esquecidos do filme não são apenas as crianças pobres das ruas: são as pessoas com deficiência que pedem esmolas, mães pobres, viúvas, doentes e idosos que travam com a pobreza a luta pela sobrevivência.

Os esquecidos de Buñuel são resultado de muitas camadas explicativas. O cineasta tenta insinuar várias delas, sem determinar nenhuma. Há uma relação que se tenta elucidar e 
várias passagens do filme segundo a qual não somente a pobreza, mas também uma força intrínseca à disciplina do trabalho, ao funcionamento das instituições correcionais, da escola e da dinâmica familiar pode ter influência sobre a situação dos meninos esquecidos das ruas. De um lado, as famílias aparecem como a instituição que oferece seus filhos à correção quando não consegue mais disciplinar os incorrigíveis - como é a cena emblemática na qual a mãe do menino Pedro leva-o para o internato, mesmo não sendo o autor do crime do qual todos o estão acusando. De outro, se há uma ausência quase total do Estado no seu papel de mitigação das desigualdades sociais - a não ser pela presença repressiva da polícia e pela tutela do internato - em determinado momento, Buñuel quer explicitar também que não há mais somente repressão e pena de morte aos delinquentes: diferentemente de outros tempos, agora existem instituições e práticas que buscam corrigir e reformar os meninos delinquentes para devolvê-los ao mundo.

A presente tese é também sobre os esquecidos. Esquecidos diferentes dos de Buñuel, é verdade. Mas não deixam de ter semelhanças com eles, principalmente pelo fato de terem sido abandonados por alguém, por suas famílias, por outros. Os esquecidos de Buñuel foram deixados nas ruas; os desta tese, numa instituição correcional-asilar, os manicômios judiciários. Os esquecidos do título desta tese são os indivíduos com doenças mentais e deficiências mentais que cometem crimes e, mesmo após receberem tratamento psiquiátrico obrigatório como condição para a ressocialização, não conseguem retornar à liberdade. Explicar as razões para esse evento foi o objetivo principal deste estudo, partindo da análise das políticas públicas envolvidas na relação entre loucura e crime, que sempre se constituiu em um desafio em diferentes sociedades - principalmente a partir do século XIX, quando novas instituições e saberes sobre a loucura e a punibilidade passaram a existir, o que modificou as atribuições dos governos perante a questão dos indivíduos loucos que cometem crimes (CASTEL, 1978; FOUCAULT, 2006).

O Brasil, por ter se inspirado tanto em compreensões quanto em respostas europeias ao problema da loucura e das infrações penais, destinou a inimputabilidade aos indivíduos que, comprovadamente doentes ou deficientes mentais, cometem crimes. Ou seja, eles não recebem uma sanção penal pelo crime cometido, mas tratamento psiquiátrico obrigatório por tempo indeterminado, que pode ocorrer com ou sem restrição de liberdade. Por razões a serem exploradas aqui, há indivíduos que permanecem em reclusão mesmo após o cumprimento dos procedimentos psiquiátricos e penais obrigatórios para o retorno à liberdade. Esta tese investiga a fase de desinternação desses indivíduos após terem a periculosidade declarada 
cessada pela psiquiatria e sentenciada pelo juiz, por meio de uma análise das políticas sociais envolvidas nesse momento de retorno à liberdade dos indivíduos que cumpriram medida de segurança.

Desde 1940, o Código Penal brasileiro estabelece o tratamento psiquiátrico obrigatório como medida de segurança imposta aos indivíduos inimputáveis por doença e deficiência mental que cometem crimes (BRASIL, 1940). O cumprimento das medidas de segurança ocorre em Hospitais de Custódia e Tratamento Psiquiátrico (HCTPs) ou em estabelecimentos equivalentes, como Alas de Tratamento Psiquiátrico (ATPs) localizadas em presídios comuns (BRASIL, 1940). As medidas de segurança são de dois tipos: de tratamento ambulatorial e de internação, sendo essas últimas cumpridas em restrição de liberdade. Ambas têm a duração indeterminada, estendendo-se até que a periculosidade do indivíduo seja considerada cessada por perícia psiquiátrica. Periculosidade é um conceito jurídico e penal do Código Penal que aponta a possibilidade de o indivíduo cometer nova infração penal como decorrência de seu estado mental (ALMEIDA, 2005). As perícias são realizadas anualmente depois de encerrado o período mínimo de internação determinado na sentença judicial.

Em 2011, havia 26 Estabelecimentos de Custódia e Tratamento Psiquiátrico (ECTPs) no Brasil: 23 HCTPs e 3 ATPs localizadas em presídios ou penitenciárias (DINIZ, 2012). Nos estados de Acre, Amapá, Goiás, Maranhão, Mato Grosso do Sul, Roraima e Tocantins não havia nem HCTP nem ATP. Os 23 HCTPs estavam localizados em Alagoas, Amazonas, Bahia, Ceará, Espírito Santo, Minas Gerais, Pará, Paraná, Pernambuco, Piauí, Rio de Janeiro, Rio Grande do Norte, Rio Grande do Sul, Santa Catarina, São Paulo e Sergipe. As três ATPs estavam localizadas no Distrito Federal, no Mato Grosso e em Rondônia. Os estados de Minas Gerais, Rio de Janeiro e São Paulo possuíam três HCTPs cada, e os demais 17 estados possuíam um único ECTP. Em 2011, a população total dos 26 ECTPs era de 3.989 indivíduos, entre os quais 2.956 cumpriam medida de segurança e 1.033 estavam em situação de internação temporária, aguardando laudo de insanidade mental, sentença ou julgamento (DINIZ, 2012).

O estudo A custódia e o tratamento psiquiátrico no Brasil-Censo 2011, realizado nos ECTPs pelo Ministério da Justiça e pela Anis - Instituto de Bioética, Direitos Humanos e Gênero, revelou que 25\% (741) dos indivíduos em medida de segurança não deveriam estar internados nos HCTPs ou nas ATPs por já terem cumprido os critérios para a liberdade 
(DINIZ, 2012). ${ }^{1}$ Esses indivíduos estavam em medida de segurança com a periculosidade cessada, ou com sentença de desinternação condicional decretada, ou com a medida de segurança extinta (quando a pena foi cumprida e o juiz declarou extinta a medida); ou estavam internados sem processo judicial, ou ainda já tinham recebido o benefício judicial da alta ou desinternação progressiva (DINIZ, 2012). Isto é, em 2011, 1/4 da população em medida de segurança dos ECTP do país estava indevidamente em restrição de liberdade. A persistência da internação dos indivíduos nos ECTPs, mesmo cumprindo com as exigências para o livramento, é um desafio para as políticas de segurança pública, saúde mental e assistência social.

Os indivíduos com atestado de cessação de periculosidade e com medida de segurança extinta, mas ainda internados nas unidades de custódia e tratamento psiquiátrico, são representantes de um grupo maior que expressa uma série de desafios à execução das medidas de segurança (DINIZ, 2012). Há também pessoas em alguma fase irregular de cumprimento das medidas de segurança, como atrasos na realização anual dos exames de cessação de periculosidade. Das 2.956 medidas de segurança no país, 49\% (1.194) estavam atrasadas na realização anual do exame de cessação de periculosidade (DINIZ, 2012). Dos 353 indivíduos em situação de internação temporária que aguardavam o laudo de sanidade mental, 54\% (192) estavam no HCTP ou na ATP além do prazo de 45 dias estipulado pelo Código Penal. O atraso médio do exame que atesta a insanidade mental era de 10 meses (DINIZ, 2012).

Dados levantados durante o estudo censitário nos ECTPs de 2011, mas ainda não publicados, indicaram algumas das razões da não desinternação de indivíduos que já cumpriram os critérios legais para o livramento, tendo sentença de desinternação e medida de segurança extinta. ${ }^{2}$ Para $67 \%$ (130) dos 194 indivíduos no país com sentença de desinternação, o motivo de permanecerem internados é a ausência de contatos familiares ou de local de moradia. Para 51\% (29) das medidas extintas encontradas nos ECTPs, a não desinternação ocorreu pelos mesmos motivos. Esses dados, levantados de forma exploratória no estudo censitário, indicam caminhos explicativos para a problemática a ser investigada e aprofundada nesta tese. Isto é, há uma relação entre o apoio familiar e a assistência prestada

\footnotetext{
${ }^{1} \mathrm{O}$ autor desta tese compôs a equipe de pesquisadores da Anis - Instituto de Bioética, Direitos Humanos e Gênero que realizou o estudo censitário nos HCTPs e nas ATPs do país em 2011. Foi supervisor do estudo na fase de levantamento de dados em campo, tendo visitado todos os 26 ECTPs. Foi responsável pelas fases de elaboração do instrumento de coleta de dados, pré-teste do instrumento, coleta de dados e supervisão do trabalho de campo, além de ter feito parte da equipe de análise dos dados e da elaboração do relatório final do estudo censitário.

${ }^{2}$ Esses dados foram levantados durante o estudo censitário realizado em 2011 pelo Ministério da Justiça e pela Anis, mas não foram publicados junto aos demais. $\mathrm{O}$ autor desta tese teve autorização para utilização desses dados, que são um importante ponto de partida para as análises aqui realizadas.
} 
aos indivíduos na fase de desinternação que pode ser decisiva para o momento do livramento de quem cumpre uma medida de segurança.

Em um estudo realizado em 2010 no HCTP Heitor Carrilho, no Rio de Janeiro, foi mostrado que um dos principais critérios avaliados pelos peritos psiquiatras para o diagnóstico da cessação da periculosidade era o chamado apoio sociofamiliar (MECLER, 2010). Kátia Mecler sustenta que, diferentemente de um hospital psiquiátrico comum, em um manicômio judiciário a remissão dos sintomas do indivíduo em medida de segurança não é razão suficiente para a alta médica, ou seja, para o livramento dos indivíduos. A despeito da ausência de sintomatologia e da presença de bom comportamento durante a medida de segurança, a falta de apoio sociofamiliar pode levar à perpetuidade da medida de segurança. Os peritos têm compreendido que a família auxilia na assistência ao indivíduo, principalmente para a continuidade do tratamento fora da custódia (MECLER, 2010). Isto é, para a psiquiatria e o direito penal, o apoio sociofamiliar se transforma em uma das condições objetivas que facilitam o retorno ao convívio social, o que pode resultar em obstáculos para o livramento dos indivíduos quando estes não têm esse apoio. Esta tese irá explorar a existência dessa relação e suas consequências.

Tal situação se torna mais complexa porque uma característica das infrações penais cometidas pelos indivíduos com doença ou deficiência mental é a proximidade com suas vítimas. No Brasil, em 27\% (771) das 2.956 medidas de segurança, a vítima foi um membro do grupo doméstico ou familiar dos agressores (DINIZ, 2012). Esse cenário chega a ser mais grave em unidades específicas, como no HCTP de Maceió, em que 67\% das infrações penais cometidas pela população em medida de segurança tinham um membro da família como vítima. No HCTP do Pará, 44\% das vítimas dos indivíduos em medida de segurança eram do grupo familiar dos indivíduos e, no HCTP Barbacena, $43 \%$ das infrações penais cometidas pelos indivíduos em medida de segurança foram cometidas contra um membro da família (DINIZ, 2012). Além disso, em todo o país, 45\% dos indivíduos que cometeram ou tentaram cometer homicídio o fizeram contra um membro de seu grupo familiar ou doméstico (DINIZ, 2012). Essa particularidade das infrações penais que levam a medidas de segurança pode ter consequências diretas para o retorno ao convívio social dos indivíduos pela relação conflituosa com suas famílias.

Desse modo, as relações mantidas entre o indivíduo em medida de segurança e sua família ganham importância por dois motivos. O primeiro deles é que o retorno ao convívio social do indivíduo passa por uma fase de desinternação condicional que exige a continuação 
do tratamento psiquiátrico fora do HCTP ou da ATP. Nesse caso, as condições para manter a cessação de periculosidade são transferidas para fora do HCTP ou da ATP. Há um conjunto de regras que estabelecem atividades, práticas e comportamentos autorizados e proibidos no período de desinternação condicional. O descumprimento dessas regulações para a desinternação condicional pode resultar na reinternação do indivíduo: uma das principais é a não continuidade do tratamento. Em segundo lugar, a autonomia reduzida do indivíduo egresso de HCTP e ATP, seja pela doença, seja pela deficiência mental ou pelo próprio período de internação, faz com que o livramento dependa de assistência ao indivíduo para o desenvolvimento de atividades diárias básicas, e geralmente pressupõe-se que essa atenção será oferecida pelas famílias em razão da ausência de políticas públicas com essa finalidade (MECLER, 2010). O somatório de, no mínimo, esses dois motivos pode revelar um papel importante da relação entre as famílias e os indivíduos em medida de segurança, principalmente no momento da desinternação.

É possível que haja explicações sociológicas, institucionais e sociais diferentes para cada caso de internação indevida nos manicômios judiciários. São situações indevidas e irregulares de uma população talvez das mais vulneráveis socialmente. Por suas características singulares, esse grupo teve um sistema de imputabilidade que, embora diferenciado, produz situações dramáticas: indivíduos esquecidos pelas próprias instituições assistenciais, pela justiça, pelas famílias e pelas ações do Estado. Por motivos distintos, mas com traços que os unem, esse grupo pode ser classificado como os esquecidos do sistema de inimputabilidade penal no Brasil. Esses esquecidos são indivíduos que, por motivos externos ao funcionamento das medidas de segurança - como o apoio e a promoção das condições para o livramento - ou internos à própria execução das medidas - como burocracia ou ineficiências administrativas traduzidas em atrasos - , fazem com que essa população experimente situações de punição com restrição de liberdade mesmo dentro do sistema de inimputabilidade penal.

São esquecidos de um sistema de inimputabilidade montado para controlar indivíduos não pelo que fizeram, mas pelo que são. Em outras palavras, o dispositivo de segurança do tratamento obrigatório volta-se à periculosidade alegada sobre eles, e não aos atos que eles cometeram. Os esquecidos dos manicômios judiciários no Brasil são aqueles que alguns hospitais de custódia e tratamento psiquiátrico denominam de "problema social", como é o caso do HCTP de Salvador (BRASIL, 2010a), ou de "abrigados", como é o do HCTP Heitor Carrilho, do Rio de Janeiro (MECLER, 2010). O fato de algumas unidades terem criado 
termos próprios, como "problema social" ou "abrigados", para se referir aos indivíduos que cumpriram com todas as exigências para o livramento, mas continuam indevidamente em restrição de liberdade, denota a particularidade de tal situação. A combinação entre ausência de ações específicas para favorecer o livramento dos indivíduos e ausência de assistência pública pode levar à mais severa das exclusões: a restrição perpétua de liberdade. Além disso, o caráter híbrido dos manicômios judiciários (CARRARA, 1998), ao mesmo tempo instituições hospitalares e de segurança pública, transforma a situação de dependência institucional dos indivíduos aptos a serem libertos em um limbo para a justiça, para a assistência psiquiátrica, para a assistência social e para a própria responsabilidade familiar no que toca ao apoio a esses indivíduos.

O limbo para os esquecidos é em razão de esses indivíduos não serem reconhecidos como potencial público-alvo das políticas de assistência pública ${ }^{3}$ (tanto da política de saúde mental quanto da política de assistência social), nem somente da política de segurança pública. Se as políticas de assistência social e de saúde mental amadureceram a partir dos anos 2000 e conseguiram alcançar grande parte das situações de vulnerabilidade social ligadas às privações materiais e à necessidade de assistência em saúde mental, para os indivíduos em medida de segurança, tais políticas ainda têm alcance tímido. Os principais programas, benefícios e equipamentos públicos da assistência social e da política de saúde mental não pressupõem as necessidades dos indivíduos que cumpriram medida de segurança como situações a serem atendidas por essas duas políticas. À exceção do Programa De Volta para Casa (BRASIL, 2003), que pode ser destinado aos indivíduos que estiveram por longos períodos internados em ECTP, e de previsões oferecidas em equipamentos de saúde, como os Centros de Atenção Psicossocial (CAPS) (BRASIL, 2002), e de assistência social, como os Centros de Referência em Assistência Social (CRAS) (BRASIL, 2004), não há políticas públicas específicas para os indivíduos em medida de segurança, o que cria obstáculos para a

\footnotetext{
${ }^{3}$ Nesta tese, o termo "assistência pública" será utilizado para designar conjuntamente as políticas de assistência social, previstas na Lei Orgânica da Assistência Social, de 1993, e a política de saúde mental, prevista na Lei 10.216, de 2001. Como se trata de analisar articuladamente o papel dessas duas políticas como direitos do usuário e responsabilidades do Estado para atender demandas da população em sofrimento mental, em especial, aquela que cumpre medida de segurança, o termo "assistência pública" designará sempre as duas ações. Quando for pertinente, as políticas serão nomeadas separadamente como "política de assistência social" e "política de saúde mental". O autor desta tese reconhece o importante debate a respeito da nomenclatura "atenção em saúde" em substituição ao termo "assistência em saúde" e compartilha do entendimento de que atenção à saúde é um termo mais adequado para escapar de reducionismos que possam relacionar assistência em saúde a aspectos meramente de atendimento individual, enquanto atenção à saúde relaciona-se a processos coletivos, da prática da saúde coletiva (MATTA; MAROSINI, 2014).
} 
desinternação condicional. Além disso, é quase automática a compreensão de que a política de segurança pública não tem vocação ou capacidade para atuar de forma isolada nessa fase.

O modelo de inimputabilidade penal para os indivíduos com doença ou deficiência mental foi erguido no Brasil em um momento no qual a atenção em saúde mental e a assistência social estavam assentadas em outras bases. Nos anos 1940, não havia compreensão a respeito da responsabilidade do Estado em atender necessidades básicas dos indivíduos em sofrimento mental, em contraste com os objetivos presentes atualmente tanto na política de saúde mental quanto na política de assistência social (BRASIL, 1993, 2001). O acesso à política de saúde era uma decorrência de direitos trabalhistas, portanto, limitada aos trabalhadores formais, e a assistência social - limitada e esparsa no território nacional estava ligada às práticas caritativas e filantrópicas de iniciativas espontâneas da sociedade civil, que tinha apoio apenas parcial dos governos no financiamento (BOSCHETTI, 2006). No máximo, a assistência pública a indivíduos em sofrimento mental contava com a tutela asilar oferecida pelos manicômios, que apartavam os indivíduos do convívio social e comunitário (AMARANTE, 1994; DELGADO, 1992; ENGEL, 2001).

Esse prisma delineava a atenção aos indivíduos em sofrimento mental que cometessem crimes meramente como um tema da alçada da segurança pública. À medida que o paradigma de atenção à saúde mental foi sendo alterado, a partir dos anos 1990 e 2000, e as políticas de saúde mental e de assistência social foram sendo reestruturadas, passou-se a levantar análises de que a situação das pessoas em sofrimento mental que cometem crimes não é tema de exclusividade da segurança pública. No entanto, a política de saúde mental e de assistência social sobre novas bases a partir dos anos 2000 ainda não foi suficiente para evitar o aparecimento dos esquecidos dos manicômios judiciários.

A palavra "esquecido" tem diferentes significados, o que a torna emblemática para o grupo populacional retratado nesta tese: aquele de quem se esquece frequentemente, aquele a quem não se dá importância ou aquele que foi abandonado, deixado à própria sorte. Os esquecidos desta tese, assim como os de Buñel, são indivíduos plasticamente invisíveis à sociedade, mas carregam o estigma da periculosidade. Os esquecidos dos manicômios judiciários compõem a população dos HCTPs, que, até 2011, sequer tinha sido contada no Brasil. E para existir no imaginário social e nas políticas públicas, primeiramente, uma população precisa ser contada (DINIZ, 2012). Não é objetivo desta tese explicar os motivos do funcionamento indevido dos ECTPs, como as explicações para atrasos e ineficiências do tratamento psiquiátrico, mas investigar as possíveis explicações para a não desinternação 
daqueles indivíduos que já cumpriram todas as etapas para o livramento, em uma interface das políticas de saúde mental, assistência social e segurança pública.

Não se pretende aqui contar a história dos esquecidos, nem a história das instituições que tornaram viável a existência deles. É impossível delinear as existências dos esquecidos apenas por um estudo, seja qual for a abrangência e a metodologia. Não se pretende dissecar as condições de existência ou a totalidade da vida dos esquecidos dos manicômios judiciários. Esses esquecidos têm uma existência própria nas instituições que os encarceram, e são os elementos que sustentam essa existência que se buscará aqui. Os indivíduos esquecidos não são o oposto do sujeito livre com doença mental, pois representam o ponto de inflexão das instituições que esquadrinham suas vidas, as condições de reprodução e permanência delas. $\mathrm{O}$ que pode ser falado dos esquecidos não é uma série de histórias próprias, de encadeamento de trajetórias, de dados que se repetem em um padrão ao mesmo tempo detectável pelos saberes e inteligível para as práticas. O que pode ser falado dos esquecidos é apenas aquilo a partir do quê as instituições, as práticas e os saberes tocam, caracterizam, definem e eternizam.

A existência de homens infames seria totalmente desconsiderada pela memória e pela história humanas se não fosse o ponto de encontro deles com o poder (FOUCAULT, 2003a). Para Foucault, "vidas que são como se não tivessem existido, vidas que só sobrevivem do choque com um poder que não quis senão aniquilá-las, ou pelo menos apagá-las, vidas que só nos retornam pelos efeitos de muitos acasos, eis aí as infâmias das quais eu quis, aqui, juntar alguns restos" (2003a, p. 210). Há muitos outros no Brasil, mas os esquecidos dos manicômios judiciários são os homens infames produzidos pelo dispositivo das medidas de segurança. Sem dúvida, o que alçou à condição de problemática social dos indivíduos loucos que cometem crimes é o seu ponto de encontro com o poder, isto é, a resposta que a sociedade ofereceu ao problema do crime cometido pelo louco, seja pelo encarceramento, seja pelo tratamento, seja por um misto dos dois. É importante saber por que em um determinado momento, em uma dada época e em noções muito precisas de história, política e economia temos a produção dos esquecidos dos manicômios judiciários. Não há outra motivação sociológica para a análise desse fenômeno que não a busca pelas condições de possibilidade de suas existências.

Nesse sentido, o surgimento dos esquecidos dos manicômios judiciários brasileiros tem relação com as instituições, as práticas e os saberes relacionados a eles. Esta tese explicará o surgimento dos esquecidos dos manicômios judiciários não no sentido meramente negativo da abordagem das causas do isolamento e da exclusão, mas por meio da análise de 
práticas, saberes e instituições — isto é, das políticas sociais de assistência social e de saúde mental - que sustentam as condições para que tal grupo populacional tenha surgido. Com esse ponto de partida, esta tese se organiza em três grandes eixos analíticos: um teórico, um genealógico e o outro de análise de política pública. Os três eixos não estão localizados em momentos estanques na tese. Estão mais presentes em um e em outro capítulo, mas, de forma geral, os três eixos perpassam por todos os capítulos para organizar a análise. O eixo teórico busca elucidar a ideia do familismo nas políticas sociais brasileiras, com o objetivo de subsidiar a definição do problema a ser investigado na análise empírica.

O familismo é uma característica das políticas sociais que destina às famílias grande parte da responsabilidade pela provisão de bem-estar social, em vez de essa provisão ser oriunda do funcionamento de políticas públicas mantidas sob responsabilidade do Estado (ESPING-ANDERSEN, 2000). A hipótese investigada nesta tese foi a de que os indivíduos que já cumpriram a medida de segurança permanecem em reclusão indevidamente porque há insuficiência de políticas públicas para lhes oferecer assistência - recaindo sobre as famílias a responsabilidade de atender às suas necessidades - e muitos desses indivíduos não contam com o apoio familiar. Isto é, o familismo nas políticas sociais causa a continuação indevida da restrição de liberdade dos indivíduos em medida de segurança que não têm apoio familiar, ainda que atendam os critérios psiquiátricos e penais para o livramento. Com a finalidade de testar essa hipótese, esta tese investigou como se dá o itinerário de desinternação dos indivíduos em medida de segurança na interface entre as políticas de saúde mental, assistência social e segurança pública. Foi verificado se há uma importância dada pela execução das medidas de segurança às relações mantidas entre os indivíduos e suas famílias, sobretudo, no momento de desinternação dos indivíduos pela ausência ou ineficiência de ações públicas.

O primeiro eixo analítico desta tese busca subsidiar a hipótese do familismo nas políticas sociais e sua centralidade, perante outras hipóteses, para explicar o fenômeno dos esquecidos dos manicômios judiciários. Há importantes estudos que buscam levantar a característica do familismo nas políticas sociais na Europa, na América Latina e no Brasil (ESPING-ANDERSEN, 2000; MIOTO; CAMPOS, 2003; SUNKEL, 2006). O familismo como um traço das políticas sociais pode ser deletério para a efetivação da proteção social no país e para o exercício da cidadania que aposta na efetivação de políticas públicas dedicadas às necessidades básicas dos indivíduos. Há estudos no Brasil sobre a presença do familismo nas políticas sociais e o quanto esse familismo pode ser um obstáculo à efetivação da cidadania e à mitigação das desigualdades sociais (LINS, 2013; MIOTO; CAMPOS, 2003). 
No entanto, não há estudos que relacionem o familismo nas políticas de assistência social e de saúde mental às ações voltadas para os indivíduos em medida de segurança. Tampouco há estudos que investigam se esse traço do familismo nas políticas sociais pode causar restrição de liberdade indevida aos indivíduos em medida de segurança que estão aptos a retornar à liberdade, mas permanecem reclusos por não possuírem contatos e assistência familiar.

No entanto, é possível que haja alegações sobre as limitações dessa hipótese do familismo. Sua abrangência, generalidade e abstração talvez sejam os principais alvos. Podese alegar até mesmo que, antes de testar o familismo nas políticas de assistência social e saúde mental como explicação do surgimento dos esquecidos nos manicômios judiciários, várias outras etapas de funcionamento das medidas de segurança mereceriam atenção analítica. Esta tese não descarta nem menospreza tais possibilidades, pelo contrário: quer incentivar desdobramentos de pesquisa a partir de agora, na medida da análise comprometida com a compreensão que o tema complexo exige para alcançar pontos que não são atingidos aqui. Como o equilíbrio entre a análise geral e a compreensão no nível do enquadramento do específico é o grande objetivo de muitos dos estudos qualitativos nas ciências sociais, falhar nesse empreendimento pode ser causa da ineficiência geral das análises propostas. Este estudo buscou estabelecer uma linha de diálogo entre: 1. os cenários gerais levantados de forma inédita pelo estudo censitário dos manicômios judiciários publicado em 2012; 2. as políticas de assistência social e de saúde mental; e 3. um estudo de caso sobre a fase de desinternação dos indivíduos em medida de segurança no Distrito Federal. Com isso, essa metodologia mista, com métodos quantitativos e qualitativos na coleta e análise dos dados (CRESWELL, 2007), buscou compreender o fenômeno geral do surgimento dos esquecidos, como será demonstrado no capítulo que trata dos procedimentos metodológicos.

Com a hipótese do familismo, visa-se tornar compreensível uma forma de produção de abandono que soa estranha diante dos avanços de determinadas políticas sociais nos últimos anos voltadas à mitigação e superação de privações sociais no Brasil. Se se prestar atenção às respostas do Estado nos últimos anos, no nível da superfície das ações de algumas de suas políticas públicas, serão levantadas ações públicas potencialmente capazes de evitar a situação dos indivíduos que, sem condições de retorno à liberdade, permanecem em reclusão indevida nos ECTPs. Mas há algo dessas ações que pode não fazer efeito para os indivíduos em medida de segurança em fase de desinternação, pelo fato de tais políticas não reconhecerem tais indivíduos como seu público-alvo. Além disso, de modo geral, há poucos estudos sobre a fase de desinternação dos indivíduos em medida de segurança. Este, talvez, seja um dos primeiros 
estudos de abrangência, que se desdobrou a partir de dados da pesquisa A custódia $e$ o tratamento psiquiátrico no Brasil: censo 2011. Se a produção de conhecimento de diferentes campos do saber no Brasil, para tirar o melhor proveito dos dados do estudo censitário, vai indicar que será preciso de estudos gerais, abrangentes e globais e não estudos de caso para testar os diversos universos específicos, ainda é prematuro e só o acúmulo da produção científica dirá.

É importante não apenas dispor de análises capazes de verificar o alcance das políticas sociais na sua efetividade global ou local que poderiam favorecer a proteção dos indivíduos no processo de desinternação dos ECTPs, mas também verificar como e por que as políticas públicas existentes reconhecem ou não esses indivíduos como alvo de suas ações. $\mathrm{O}$ alargamento das ações já existentes para atender os indivíduos em medida de segurança certamente enfrentará impedimentos, e é preciso lançar luz sobre eles durante a análise. Não se está querendo justificar a ideia de que não seja importante avaliar a efetividade das ações, principalmente de assistência social e de saúde mental, para as pessoas em medida de segurança. Na verdade, é preciso também alargar a compreensão no sentido de promover estudos que investiguem os determinantes da ampliação ou diminuição da capacidade das ações da assistência social e dos serviços de saúde mental de alcançar os indivíduos em medida de segurança.

Nesse sentido, este estudo vislumbra, na hipótese do familismo, conjecturas de que não é somente a falta de ações ou a omissão do Estado que poderiam explicar o surgimento dos esquecidos dos manicômios judiciários. Também algo do interior das políticas já existentes, de suas estruturas, de seus porões e suas bases de sustentação, pode explicar por que tais ações são limitadas e não expansivas. É preciso aprofundar na investigação das características e dos princípios das políticas sociais para analisar suas condições e capacidades para ampliação a fim de atender o maior número possível de indivíduos, como aqueles em medida de segurança. Essas medidas são executadas desde 1940, no entanto, políticas robustas de assistência social e de saúde mental estão presentes no Brasil somente a partir dos anos 2000. Há um hiato na própria possibilidade de compreensão da capacidade dessas políticas em atender demandas dos indivíduos em medida de segurança. Para isso, antes de mais nada, pode ser fundamental o olhar para as características estruturantes e definidoras de tais políticas.

O segundo eixo analítico desta tese é o eixo genealógico. Nos termos de Foucault (1977, 2003b), a pesquisa genealógica busca explicar os fatores históricos que originam e 
sustentam as formas atuais das práticas, dos saberes e das instituições que conhecemos. A genealogia seria o empreendimento de buscar, nos escombros do passado, a força que ilumina as arquiteturas do presente. Em outras palavras, a preocupação histórica na genealogia não é uma pesquisa do tipo que visa compreender criticamente os meandros do passado, mas entender as condições históricas de existência através das quais se tornou possível o engendramento das práticas presentes e acessíveis na contemporaneidade. No eixo genealógico desta tese, faz-se uma genealogia nas políticas de assistência social e de saúde mental em busca de traços do familismo presente em tais ações públicas. Houve um amadurecimento incontestável das políticas de assistência social e de saúde mental nas duas últimas décadas no país. Há, em certo sentido, até mesmo um frisson ao comemorar a ruptura dessas políticas com o passado no nível da tecnicidade, da profissionalização e do amadurecimento alcançados por tais ações recentemente. No entanto, a ruptura com o legado dessas duas políticas públicas pode não ter sido total. Ou seja, o fato de que tais políticas não alcançaram ainda os indivíduos em medida de segurança pode evidenciar algo da ruptura incompleta com as ações do passado dessas políticas.

É possível fazer a genealogia do familismo na política de assistência social e de saúde mental, no Brasil, para explicar o aparecimento dos esquecidos dos manicômios judiciários por vários motivos. Em primeiro lugar, porque há uma expectativa de que a família tenha responsabilidade de provisão material, social e afetiva aos indivíduos loucos submetidos às medidas de segurança em fase de desinternação condicional (MECLER, 2010), como os próprios dados levantados pelo estudo censitário e citados anteriormente demonstram. Entretanto, há um impasse para a satisfação dessa expectativa por duas principais conjecturas: 1. a família simplesmente pode não ter condições de receber o indivíduo com transtorno mental em medida de segurança em fase de desinternação, seja pelas vulnerabilidades sociais da família, seja pela própria impossibilidade para o cuidado em função da dinâmica e composição familiar; e 2. a provisão por parte das famílias esbarra na relação conflituosa entre o indivíduo e sua família: a maioria deles cometeu crime contra membros familiares. Ou seja, a recusa em receber os indivíduos desinternados pode resultar da alegação de perigo pelas famílias.

Em segundo lugar, o familismo a ser investigado nas políticas de assistência social e saúde mental pode ser resultado da não substituição da centralidade da família nas provisões de assistência e apoio aos indivíduos. Essa não substituição ou substituição incompleta da família como meio de provisão de bem-estar pode ser resultante do processo parcial de 
amadurecimento das políticas públicas brasileiras, do ponto de vista da responsabilidade do Estado na implementação, manutenção e ampliação delas (MIOTO; CAMPOS, 2003; LINS, 2013). Isto é, os esquecidos dos manicômios judiciários podem ser resultado do familismo presente nas políticas sociais, que, por sua vez, pode decorrer de processos estruturantes da atuação do Estado e dos governos no Brasil. O familismo - com suas motivações, características e consequências — funcionaria como uma espécie de aquário invisível com paredes resistentes que impede que o atendimento das necessidades dos indivíduos seja visto e implementado sob o prisma da responsabilidade do Estado. Fazer a genealogia do familismo na assistência social e saúde mental, no Brasil, é investigar as estruturas de base dessas paredes invisíveis, o que pode auxiliar no desvendamento das características das políticas públicas que as impedem de se desenvolver e se estender para alcançar os indivíduos em medida de segurança.

Em certo sentido, fazer a genealogia do familismo na assistência social e na saúde mental é buscar as pegadas e impressões, revirar as compreensões insuficientes, organizar os trajetos limitados, elucidar as evidências e sinais decifráveis que explicam, mesmo que por um e não por todos os lados possíveis, o processo pelo qual o Estado não conseguiu promover a desfamiliarização (ESPING-ANDERSEN, 2000) nas políticas sociais voltadas aos indivíduos com doenças mentais. Fazer a genealogia do familismo nas políticas de assistência social e de saúde mental é, também, buscar a explicação sobre o surgimento de determinadas ações não planejadas que surgem, inesperadamente, do desdobramento de uma ação planejada. Isto é, não se espera revelar o que está por trás da produção do familismo nas políticas sociais naquilo que seja meramente resultado da ausência total do Estado diante do atendimento de necessidades básicas dos indivíduos. É possível que o familismo nas políticas sociais emirja justamente nas fendas entre as ações públicas, racionais e planejadas já existentes e não meramente pela inexistência delas. É imprescindível levar em consideração esse viés para a formação de um quadro analítico do familismo nas políticas sociais no Brasil.

O terceiro eixo da tese é o da análise de política pública. Esse eixo também não é visto separadamente, mas em total relação com os dois eixos anteriores. Busca-se uma análise do itinerário de desinternação dos indivíduos em medida de segurança por meio do estudo de políticas públicas, tais como de segurança pública, assistência social e de serviços substitutivos de saúde mental, com o intuito de fazer funcionar uma observação do Estado em ação nesse processo de desinternação. A análise de política pública pode ser definida como um conjunto de elaborações sobre conhecimentos produzidos em diversas disciplinas das 
ciências humanas, objetivando examinar e resolver problemas concretos em políticas públicas (DAGNINO, 2000). Ou seja, o conhecimento acerca das políticas públicas vislumbra interpretar as causas e as consequências das atuações dos governos na elaboração, na implementação e no acompanhamento de determinada ação política voltada para resultados, com alocação de recursos e desenhada para longa duração. Desse modo, nesta tese será realizada uma análise de política pública das ações de assistência social e de saúde mental no intuito de avaliar como essas ações alcançam os indivíduos em medida de segurança na fase de desinternação.

Os três eixos analíticos do estudo estão presentes nos seis capítulos que compõem a tese. No primeiro capítulo, será explicitada a ideia do familismo e como ela subsidia a hipótese a ser testada na análise empírica. O que se compreende como familismo nesta tese está exposto de forma germinal nas ideias de Gøsta Esping-Andersen (2000). No entanto, a análise feita nesta tese amplia, no caso das medidas de segurança, essa compreensão clássica do familismo como traços das políticas sociais que poderiam apontar para um recuo do Estado e um aumento de participação das famílias no papel de provisão de bem-estar social aos indivíduos. Pois, como será trabalhado no primeiro capítulo, as medidas de segurança como um dispositivo de segurança voltado para o controle dos indivíduos (FOUCAULT, 1977) - estão baseadas na psiquiatria e no direito penal, que, por sua vez, dependem de um funcionamento bastante peculiar das famílias no que diz respeito ao disciplinamento dos indivíduos. Há, no caso das medidas de segurança, particularidades sobre as atribuições das famílias como instâncias que oferecem os indivíduos às instituições disciplinares, e essas particularidades impulsionam ainda mais a necessidade de investigar o familismo presente nas políticas sociais.

Por outro lado, nos termos de Foucault (1977), as medidas de segurança condensam, sintetizam e traduzem muitos dos traços das políticas públicas sociais no Brasil nos últimos anos: as transformações das funções do Estado no que diz respeito às suas funções de governo na utilização de técnicas, saberes e estratégias com ações racionais voltadas para a população, para os domínios da vida dos indivíduos. Esse saber, denominado por Foucault de “governamentalidade" (2008), é a razão de ser dos governos e explica o que está por trás das ações públicas, estatais e racionais voltadas a um problema específico. As ações da assistência social e da saúde mental a partir dos anos 2000 no Brasil representaram inflexões na governamentalidade das políticas sociais no país, ao assumir novas diretrizes e características que precisam ser investigadas. No primeiro capítulo, portanto, será feito um delineamento da 
problemática que guia esta tese, bem como a explicitação da hipótese a ser testada na análise empírica.

No segundo capítulo, serão demonstrados os procedimentos metodológicos utilizados nesta tese na fase de levantamento e análise dos dados. A metodologia do estudo é do tipo qualitativa e quantitativa, contando com três fases: 1. análise da legislação penal, das leis e políticas de saúde mental e de assistência social para avaliar os limites às garantias dos direitos das pessoas em medida de segurança e o quanto essas ações podem favorecer o processo de retorno à liberdade dos indivíduos no momento da desinternação. A análise dessas políticas terá dois objetivos principais: o primeiro é investigar os traços capazes de demarcar o familismo nas políticas de assistência social e saúde mental. Em segundo lugar, ao analisar a efetividade de tais ações para os indivíduos em medida de segurança na fase de desinternação, investigar o quanto o alcance limitado dessas políticas poderá ser explicado pelo familismo; 2 . análise quantitativa e qualitativa dos dados da publicação A custódia $e$ o tratamento psiquiátrico no Brasil - censo 2011 referentes aos indivíduos que estão indevidamente em restrição de liberdade nos manicômios judiciários, com o objetivo de apresentar um perfil sociodemográfico, psiquiátrico e penal dessas pessoas a fim de mostrar particularidades dessa situação. Essa população não teve seus dados ainda analisados por nenhum estudo, apenas foi apresentado o número total de pessoas internadas indevidamente nos ECTPs e os motivos da internação; e 3. estudo de caso na Vara de Execuções Penais (VEP) do Tribunal de Justiça do Distrito Federal e Territórios (TJDFT) responsável pela execução das medidas de segurança no Distrito Federal, para avaliar os itinerários e desafios da desinternação na interface com as políticas de assistência social e de saúde mental.

No terceiro capítulo, será realizada uma genealogia do familismo na política de assistência social no Brasil. O imperativo ético e de justiça social no combate às privações sociais no Brasil, de alguma forma, sempre esteve presente nos debates públicos, pelo menos a partir da virada do regime imperial para o governo republicano, em fins do século XIX (BOSI, 1996). No entanto, durante quase todo o século XX, combater as privações esteve sob os desígnios da filantropia e da caridade, em que o Estado tinha papel meramente figurativo, quase inexistente. As ações, os benefícios e os programas que compõem a Política Nacional de Assistência Social (PNAS) somente a partir de 2004 assumiram características distintas do que se praticava no país até então. A regulamentação tardia da assistência social como política de seguridade social estabelecida na Constituição Federal de 1988 fez com que, de um lado, ela fosse reflexo das dificuldades de assimilação por parte do governo em assumir sua 
responsabilidade na materialização da assistência como política social que garante direitos fundamentais (BOSCHETTI, 2006; TAVARES, 2008). Por outro lado, a mudança de ação de um conjunto desestruturado e desarticulado de ações esparsas para uma política unificada sob a responsabilidade do Estado - não foi capaz de romper com todas as amarras do passado naquilo que definia e caracterizava as ações de assistência social como ações públicas limitadas de iniciativa espontânea da sociedade por meio da caridade e filantropia.

$\mathrm{O}$ argumento a ser defendido no terceiro capítulo será o de que o amadurecimento da política de assistência social como direito de seguridade social, a partir de 1988, só foi possível porque a responsabilidade de provisão social, material e econômica aos cidadãos foi compartilhada entre o Estado e as famílias. Em oposição ao que comumente se apresenta sobre os avanços da estatização da assistência social a partir dos anos 1990 e, de forma mais incisiva, nos anos 2000, será investigado o quanto esse processo de tecnicidade e profissionalização pública da assistência social, como parte da governamentalidade do Estado brasileiro, se deu porque tal atribuição foi legal, política e publicamente compartilhada com as famílias.

Em um sentido próximo ao realizado com a política de assistência social, no quarto capítulo será feita uma genealogia do familismo na política de saúde mental no Brasil. Os movimentos reformistas da psiquiatria proporcionaram um amadurecimento teórico sobre a questão do asilamento como paradigma de atenção psiquiátrica que esteve presente em todo o século XX no país (DELGADO, 1992). A experiência italiana da desinstitucionalização psiquiátrica, iniciada nos anos 1960 e 1970, foi tomada como referência pelo movimento de reforma psiquiátrica brasileira a partir dos anos 1980. O movimento de contestação do asilamento na assistência psiquiátrica promoveu uma reflexão ampla sobre o processo de institucionalização e chegou a criar estratégias específicas na luta antimanicomial. Essa luta culminou na Lei de Reforma Psiquiátrica, Lei $\mathrm{n}^{\circ} 10.216$, de 2001, que redefine os padrões de tratamento oferecido às pessoas em sofrimento mental de modo predominante em regime aberto, não asilar. Embora as medidas de segurança em restrição de liberdade, desde 1940, precisem ser revistas à luz dos princípios da Lei da Reforma Psiquiátrica, o agendamento do tema no campo da segurança pública e da necessidade de controle impede que esse movimento ocorra (PENALVA, 2007). Nesse sentido, o objetivo do quarto capítulo será o de explorar, por meio do método genealógico, em que medida o familismo se manifesta nas políticas e ações da saúde mental a partir de 2001, e como tais ações interferem no fortalecimento do paradigma não asilar como alternativa na assistência em saúde oferecida 
aos indivíduos com doenças e transtornos mentais. O argumento defendido no capítulo será: o processo de amadurecimento dos serviços em saúde mental em substituição ao paradigma asilar e manicomial, que esteve presente até os anos 1980, ocorreu porque tal responsabilidade do Estado com as políticas públicas foi compartilhada com as famílias. Portanto, as políticas de assistência social e de saúde mental expressam ainda vários traços do passado, como o papel preponderante das famílias na provisão de bem-estar, o que pode impedir que tais ações se desenvolvam ao ponto de alargar sua cobertura.

No quinto capítulo, será realizada uma análise aprofundada do perfil dos indivíduos esquecidos dos manicômios judiciários brasileiros. O perfil sociodemográfico, de diagnóstico e de trajetória penal dos esquecidos não foi analisado separadamente na publicação do estudo censitário em 2012. O objetivo dessa análise aqui será avançar no conhecimento sobre os esquecidos a fim de iluminar as análises posteriores e articulá-las com o estudo de caso realizado na ATP do Distrito Federal. A descrição do perfil dos esquecidos pode ajudar a elucidar muitos dos desafios envolvidos no que diz respeito às políticas sociais a serem efetivadas para essa população no momento da desinternação. Ao descortinar a realidade dos indivíduos esquecidos, será apresentada uma comparação com o perfil dos demais indivíduos em medida de segurança, com o intuito de examinar as duas populações e investigar a fundo as investigações que particularizam os indivíduos esquecidos. Além disso, a apresentação do perfil detalhado dos esquecidos dos manicômios judiciários de todo o país tem o objetivo de gerar novas reflexões, a serem realizadas por meio de outros estudos, que possam dar continuidade às análises aqui apresentadas.

Já no sexto capítulo, será realizado um estudo de caso no Distrito Federal a respeito de como a política de segurança pública atua em conjunto com as políticas de saúde mental e de assistência social no momento da desinternação condicional dos indivíduos em medida de segurança. O objetivo do capítulo será o de evidenciar o quanto as relações estabelecidas com a família dos indivíduos em medida de segurança em fase de desinternação condicional ganham relevância mais pelo familismo presente nas políticas sociais do que pela preponderância da família como ente responsável pelo restabelecimento do convívio social e comunitário do indivíduo. O estudo de caso foi realizado na Vara de Execuções Penais do TJDFT, que é responsável pela execução das medidas de segurança no DF. Não há nada que particularize a ATP do Distrito Federal em relação às das demais unidades da Federação. A escolha da ATP-DF foi no sentido de proporcionar um estudo de caso em profundidade sobre a fase de desinternação dos indivíduos em medida de segurança. Será demonstrado, no sexto 
capítulo, que, para além dos desafios inerentes ao processo de desinternação dos indivíduos em medida de segurança, o familismo nas políticas de assistência social e de saúde mental pode representar empecilhos a essa fase. 


\section{OS ESQUECIDOS E O FAMILISMO NAS POLÍTICAS SOCIAIS: DA TUTELA DA ASSISTÊNCIA À CIDADANIA INCONCLUSA}

A sociologia, a ciência política e o serviço social são três campos do conhecimento que têm como uma de suas preocupações, do ponto de vista do objeto de estudo, analisar as ações do Estado. Claro, há várias outras áreas do conhecimento com essa mesma atribuição. Mas, pelo menos para essas três, a tarefa de analisar o que o Estado tem feito a respeito daquilo que lhe foi delegado fazer ocupa grande parte das razões de ser dessas áreas. Entretanto, dizer que uma área do saber tem esse tipo de preocupação não esclarece muito a respeito da especificidade e do sucesso nos empreendimentos de tal campo. É possível alegar que quase todas as áreas do conhecimento, até mesmo das ciências exatas às artes, tem a ver, em certo sentido, com as explicações das ações do Estado. A produção de conhecimento a partir da tarefa de analisar o Estado, os determinantes de suas ações, bem como a inteligibilidade e as condições de permanência delas, consiste em preocupação central em vários campos do saber - e da sociologia em particular.

Não somente preocupação com a forma como o Estado, por meio de suas ações legais, públicas e racionais, tem conseguido êxito ou fracasso no cumprimento de suas obrigações, mas, principalmente, o que leva uma temática a ser enfrentada por ações de responsabilidade do Estado tem grande importância na produção de conhecimento nas ciências sociais e humanas. Considerando as características do Brasil das últimas décadas, com poucos períodos prolongados de estabilidade democrática no século $\mathrm{XX}$, processos tortuosos na infraestrutura econômica e heranças políticas muitas vezes pouco originais desde a republicanização do país, na virada do século XIX para o XX, verifica-se que as ações do Estado sempre foram terreno fértil para análises das ciências sociais (FAORO, 2007; HOLANDA, 1995). Como um tema é transformado de assunto privado em assunto público, em responsabilidade do Estado e não apenas dos indivíduos, das comunidades ou das famílias, é um dos pontos de partida desta tese.

O estudo A custódia e o tratamento psiquiátrico no Brasil - censo 2011 mostrou que, no Brasil, 25\% (741) dos indivíduos em medida de segurança não deveriam estar internados nos HCTPs ou ATPs naquele ano (DINIZ, 2012). Esses indivíduos estavam em medida de segurança com a periculosidade cessada, ou com sentença de desinternação condicional decretada, ou com a medida de segurança já extinta, ou ainda internados sem processo judicial, ou já tinham recebido o benefício judicial da alta ou desinternação progressiva (DINIZ, 2012). A persistência da internação dos indivíduos nos ECTPs, mesmo cumprindo 
com as exigências para o livramento, é um desafio para as políticas de segurança pública, saúde mental e assistência social. A preocupação em explicar por que tal situação ocorre é o objetivo principal desta tese.

O censo dos HCTPs levantou de forma exploratória que, dos 194 indivíduos com sentença de desinternação decretada que permaneciam internados, para $67 \%$ (130), o motivo da não desinternação era a ausência de contatos familiares ou de local de moradia (DINIZ, 2012). Para 51\% (29) das medidas de segurança extintas, a não desinternação ocorria por esses mesmos motivos (DINIZ, 2012). Se a família tem papel preponderante na fase de desinternação condicional desses indivíduos, a ausência dela pode representar um empecilho. Diferentemente do egresso do sistema penitenciário comum, os indivíduos com transtorno, doença ou deficiência mental necessitam de assistência cotidiana de um modo mais premente. É pelo fato de ainda não ser exatamente problematizado como tema de responsabilidade de ações estatais e dos governos que esse indivíduo pode permanecer no âmbito privado, de responsabilidade das famílias.

O processo de estatização dos problemas individuais e familiares, ao transformá-los em responsabilidades públicas, não se dá de forma cristalina ao ponto de ser possível falar em ações públicas genuína e exclusivamente estatais. Como analisou Jurandir Freire Costa, em sua clássica obra Ordem médica e norma familiar (1979), a formação do Estado brasileiro, no século XIX, passou pela superação dos impasses impostos pelas características centrais dos arranjos familiares em serem os principais fornecedores de proteção e de atendimento das necessidades de seus membros. É muito recente uma clareza maior do papel do Estado nessas situações, o que não significa que padrões de comportamento das ações estatais tenham deixado de compartilhar com as famílias o papel de oferecer assistência aos indivíduos.

A política de assistência social e a política de saúde mental (BRASIL, 1993, 2001) oferecem diretrizes e condições estruturais e legais no tocante ao papel do Estado na oferta de bens, serviços e programas de assistência aos indivíduos com transtorno e doença mental que necessitam de apoio para a recuperação da saúde mental e para o desenvolvimento de sua autonomia. Essas duas políticas já são, em alguma medida, a resposta do Estado a essa demanda dos indivíduos loucos que cometeram crimes e, na fase da desinternação condicional, necessitam de ações para apoiá-los no desenvolvimento de sua autonomia e no retorno à liberdade. Entretanto, com a ausência da efetividade de tais ações, a atividade de assistência das famílias pode ganhar força. 
A característica das políticas públicas em que a responsabilidade pela provisão de bem-estar social é compartilhada com as famílias é denominada de familismo (ESPINGANDERSEN, 1990). De forma resumida, o familismo representa a ausência ou presença limitada do Estado, por meio de suas políticas públicas, no tocante a suas responsabilidades, que são transferidas para as famílias (MIOTO; CAMPOS, 2003). Uma das tarefas principais desta tese foi a de investigar se o familismo está presente no universo das políticas de assistência social e de saúde mental voltadas para os indivíduos com doenças e transtornos mentais. Se a resposta à investigação for afirmativa, como o familismo se manifesta nessas políticas e como ele decorre das afirmações legais e do desenvolvimento histórico das ações estatais e racionais constituir-se-ão em perguntas a serem respondidas com as análises aqui empreendidas. O objetivo deste capítulo é o de explicitar a hipótese central testada na pesquisa que fundamenta esta tese: a de que o familismo nas políticas de assistência social e de saúde mental, no Brasil, leva os indivíduos a permanecerem em restrição de liberdade nos hospitais de custódia, mesmo cumprindo com os critérios para a desinternação.

\subsection{Ordenamento familiar e restrição de liberdade: a responsabilidade do Estado compartilhada com as famílias na assistência}

De modo geral, as explicações da sociologia para as ações do Estado requerem analisar as condições em que determinado comportamento emerge ou em que um padrão específico de ação estatal surge institucional e historicamente para determinar perfis de políticas públicas. A reprodução da vida social é complexa demais, não se deixando apreender, por exemplo, por figuras normativas rígidas, como o direito, o que pode expandir o campo de análise das ciências sociais (HABERMAS, 1997). Jurgen Habermas salienta que há toda uma literatura nas ciências sociais para persuadir o pensamento social contemporâneo de que os próprios mecanismos para a sociabilidade são de natureza não normativa (HABERMAS, 1997). Karl Marx (2004) talvez tenha sido um dos primeiros a aprofundar a ideia de que o funcionamento da sociedade moderna se revela mais pelo conjunto das relações de produção do que pelas regras ditadas pelo direito, pelos regramentos legais ou pelos planos ideais da sociedade.

Michel Foucault $(1977,2005)$ levou adiante a concepção marxista de produção da realidade material ao explicitar um esquema de respostas modernas e racionais, por exemplo, para tratamento e prevenção do crime oriundo da loucura, por meio do poder disciplinar, que envolve não somente as relações de produção, mas as instituições, as ciências e até famílias na 
produção de saberes que levam a práticas de controle dos indivíduos. Em toda a sua produção teórica, Foucault $(1977,2003 a, 2005,2008)$ ressaltou, do ponto de vista metodológico e conceitual, uma quantidade de caminhos diferentes e emaranhados para estabelecer elos entre relações de classes e instituições, entre formação de saberes específicos, instituições e práticas, como no caso do aprisionamento, do saber psiquiátrico e da higiene pública, como um dispositivo de controle dos indivíduos.

O conjunto de meios e instrumentos utilizados para qualquer resposta racional a um determinado problema — como no caso aqui analisado das medidas de segurança no Brasil — pode revelar muitos dos caminhos e descaminhos da sociedade, como suas características econômicas, políticas e culturais. A sociedade brasileira pode ter lançado mão de uma tecnologia nova de punição da loucura, como as medidas de segurança adotadas desde 1940, como resultado de condições sociais estruturais. Isto é, a tecnologia da medida de segurança aparentemente passou a atuar sobre a loucura com uma força bastante superior ao que seria, antes dela, a punição somente pelo crime cometido pelo louco. E não foi porque a loucura criminosa é um perigo que desestabilizaria a sociedade como nunca antes, mas principalmente porque a categoria de louco perigoso surge em um contexto de novos saberes e práticas no conjunto da formação da sociedade brasileira urbanizada e industrializada nas primeiras décadas do século XX (ALMEIDA, 2005; CARRARA, 1998).

Parte das explicações para o surgimento das medidas de segurança no Brasil a partir de 1940 tem relação com o fato de que, pela primeira vez, o louco que comete crimes representou uma ameaça à sociedade: punir a loucura criminosa com reclusão passou a ser requerido como técnica em defesa da sociedade (CARRARA, 1998). A punição à loucura pelas medidas de segurança surge no momento de transição do país agrário para o país urbano e industrial; a loucura, antes incorporada e assimilada pelos arranjos sociais, de repente se transformou em estorvo que precisa ser controlado. Nesse sentido, o dualismo entre individualismo e direitos coletivos, denunciado como falso no plano filosófico por Émile Durkheim (1975), no ensaio sobre o Caso Dreyfus, não só encontra terreno fértil nas ciências sociais como representa, para Habermas, a guinada do pensamento social nas ciências sociais que "mina irrevogavelmente a intervenção prescritivista e racionalista das teorias contratualistas da sociedade, como também a ideia de que o direito em geral constitui uma categoria central da teoria da sociedade" (1997, p. 72). É preciso ater-se ao que as ciências sociais conseguem iluminar no problema indivíduo versus sociedade, sobretudo, em suas 
respostas complexas dadas historicamente e ancoradas em diversos saberes que podem apagar um ou outro dos dois extremos.

É comum atribuir os objetivos da sociologia a um conjunto de elementos capazes de conhecer, descrever e analisar as condições para que seja possível a sociedade moderna existir e se estender ao longo do tempo (GUIDDENS, 2009; OUTHWAITE, 2006). Para Anthony Giddens (2009), a sociologia em seus traços contemporâneos é aquele ramo da ciência social que se concentra sobre as sociedades modernas ou avançadas com a proposta de compreender as condições da agência humana e sua relação com as instituições sociais. Por sua vez, de modo fundante no pensamento sociológico, Max Weber (2000) propôs que toda interpretação, como na ciência em geral, pretende alcançar evidência de modo que a interpretação sociológica da ação racional, ou seja, a ação orientada por um fim, "possui, quanto à compreensão dos meios empregados, um grau máximo de evidência”. O papel da sociologia na compreensão de uma atitude tomada pelo Estado para modificar alguma realidade, por exemplo, encontrará evidência máxima nos meios empregados por ele para atingir o resultado pretendido, o que não significa que as motivações e as consequências da ação tenham importância menor.

O dado apresentado na introdução desta tese a respeito de uma ação racional do Estado brasileiro talvez seja a grande motivação para as investigações e reflexões a serem discutidas nas próximas páginas: em 2011, o primeiro estudo censitário brasileiro realizado nos estabelecimentos de custódia e tratamento psiquiátrico (ECTPs) — os antigos e não desaparecidos manicômios judiciários - mostrou que, dos indivíduos com sentença judicial, um em cada quatro já deveriam estar em liberdade. O primeiro manicômio judiciário do Brasil data de 1921 (CARRARA, 1998). Isto é, foram necessários mais de 90 anos depois da primeira aparição dessa instituição híbrida no país, nos termos de Sérgio Carrara, para que sua população tivesse seu perfil fotografado e para que fossem revelados seus traços mais do que característicos. Esta tese não buscou analisar a eficácia das medidas de segurança; quando trabalha com o resultado de que um quarto das pessoas em medida de segurança dos ECTPs já deveria estar em liberdade, não faz qualquer juízo de valor a respeito do nível de eficácia da aplicação dessas medidas. Apenas anuncia uma inquietação: as evidências surgidas na análise das medidas de segurança como meios para atingir outros fins podem revelar características institucionais singulares. 
Como explicar que um quarto das pessoas em medida de segurança no Brasil já cumpriu os critérios para a liberdade, mas permanece em custódia? Por que, do universo de dados inéditos relevados pelo primeiro estudo censitário dos ECTPs no Brasil, este parece ser um dos mais inquietantes? O ponto de partida é de que as explicações para esse dado são capazes de revelar características não apenas de nossas políticas públicas e sociais dos últimos anos, mas também de nosso Estado em ação nas últimas décadas. Por pelo menos duas razões, esse dado dos indivíduos em medida de segurança presos indevidamente é importante. Em primeiro lugar, pela complexidade das medidas de segurança - tanto pela heterogeneidade das ações em termos de política de segurança pública quanto pela intersetorialidade envolvida na rede de instituições e políticas necessárias para fazer acontecer a desinternação condicional, tais como sistema de justiça e políticas de saúde, de assistência social e de trabalho etc. Em segundo lugar, pelo ponto de contato entre várias ações do Estado direcionadas a esse público, que não mais tem, do ponto de vista jurídico, justificativa para a continuação da custódia. Ou seja, as ações direcionadas a esse público ultrapassam em muito as atribuições da política de segurança pública. Os indivíduos em restrição de liberdade indevidamente estariam nessa situação por fatores que ultrapassam os muros dos manicômios judiciários.

Robert Castel sustentou, em A ordem psiquiátrica: a idade de ouro do alienismo (1978), que é possível descrever a história do hospital psiquiátrico a partir de uma compreensão geral de que o saber interior ao hospital tinha uma relação intrínseca com o mundo exterior no início do século XIX. Ou seja, o poder do hospital psiquiátrico é, antes, uma busca por apoio a um saber específico de toda a sociedade: a higiene pública. O hospital psiquiátrico teve o papel de intensificar a ordem psiquiátrica no seio da sociedade que ergueu um regime não contratual para os indivíduos loucos, que não têm o status jurídico de cidadãos cooperativos e produtivos de uma sociedade fundada na centralidade do trabalho. Castel, em uma análise exterior ao hospital psiquiátrico, estabeleceu as relações de causalidade para a construção do modelo do saber psiquiátrico não só da Europa, mas do mundo.

A obra de Castel inspirará muitas outras reflexões nesta tese. Mas, neste momento, servimo-nos dela apenas para indagar em que medida a situação dos indivíduos em medida de segurança que já cumpriram com os critérios para o livramento, e permanecem em reclusão, pode ser explicada por algo exterior ao funcionamento das medidas de segurança. Em quais pontos de apoio a essa situação é preciso prestar atenção para explicar o abandono à própria sorte dessas pessoas nos hospitais de custódia? Em quais estratégias e funcionamentos do 
sistema de execução das medidas de segurança, da psiquiatria e da justiça — ou exterior a elas - é preciso buscar causalidades e entrelaçamentos para explicar o fato de que não basta cumprir os critérios jurídicos e psiquiátricos para a liberdade? Haveria ainda outros impedimentos para o livramento dos indivíduos em medida de segurança no Brasil? Como é possível passar através das medidas de segurança, pelo funcionamento interior e exterior dos manicômios judiciários, para chegar a outros determinantes centrais da situação dos esquecidos dos ECTPs? O empreendimento para buscar as respostas a tais questionamentos não é uma tarefa simples. Este estudo não pretende explicar todas as possíveis causalidades para esse fenômeno. Mas pretende, em certa medida, caminhar por arranjos e trajetos capazes de anunciar os elementos históricos, políticos, econômicos, culturais e legais das políticas sociais no Brasil que oferecem respostas para as determinações do evento aqui investigado.

Do ponto de vista da sociologia weberiana - o de averiguar as possibilidades de compreensão dos meios para alcançar fins em uma ação racional —, a análise do surgimento dos esquecidos dos manicômios judiciários precisa estar atenta a como a implementação das medidas de segurança está articulada a outros institutos e procedimentos, principalmente na fase de desinternação condicional. A análise da norma, do direito e da psiquiatria não encontra espaço central neste estudo, que examina os meios empregados pelo Estado no itinerário de desinternação dos indivíduos em medida de segurança. No entanto, o diálogo entre o direito e a psiquiatria ocorre na medida em que as medidas de segurança são dispositivos relacionados a essas duas áreas. Embora sejam importantes análises neste sentido, não é central nesta tese julgar a pertinência das medidas de segurança como tecnologia de punição, nem a psiquiatria como uma alegação de saber que delimitará a saúde mental dos sujeitos sob custódia. Os estudos que compartilham de tal ponto de partida crítico a respeito das medidas de segurança estão de acordo com as perspectivas aqui adotadas. No entanto, o empreendimento aqui proposto centrará esforços para analisar quais meios racionais o Estado tem se disposto a utilizar para o livramento dos indivíduos em medida de segurança.

Por outro lado, quando se fala dos esquecidos dos manicômios judiciários, este estudo não pretende também emitir juízo de valor a respeito dos servidores e profissionais diretamente envolvidos na administração dessas instituições. São esses profissionais que cotidianamente compartilham o silêncio e a solidão dos indivíduos esquecidos pelos familiares, pela sociedade e, em certa medida, por outras políticas públicas e sociais. O ponto de partida de que os indivíduos em medida de segurança que permanecem indevidamente em 
restrição de liberdade são um tipo particular de esquecidos socialmente não implica indiferença ou antiprofissionalismo dos servidores dos ECTPs perante tais pessoas. Pelo contrário. A visita a todos os ECTPs do Brasil permite inferir um compromisso dos profissionais dessas instituições com o bem-estar cotidiano das pessoas internadas. $\mathrm{O}$ interesse deste estudo é o de descortinar uma realidade que ultrapassa os limites pessoais de cada agente público do interior desses estabelecimentos em promover a reinserção devida aos indivíduos na fase da desinternação condicional após a cessação da periculosidade.

Além da obra de Castel, os livros O poder psiquiátrico (2006), Os anormais (2001), Vigiar e punir: nascimento da prisão (1977), História da loucura na Idade Clássica (2005) e Segurança, território, população (2008), todos de Michel Foucault, têm influência considerável sobre os caminhos escolhidos para formar um quadro de análise da situação dos indivíduos que cumprem medida de segurança numa instituição híbrida, como são os manicômios judiciários no Brasil. Em seus empreendimentos sobre os estudos do saber psiquiátrico, das tecnologias de punição, do surgimento da sociedade disciplinar na fase contemporânea das sociedades capitalistas e da atuação do Estado diante dos dispositivos de segurança destinados à população, Foucault estabeleceu conceitos-chaves indispensáveis para o tema aqui proposto. As condições de possibilidade de surgimento dos indivíduos esquecidos dos ECTPs podem ser desvendadas por meio de relações intricadas entre discursos de saber e dispositivos de poder que emergem das ações estatais no tocante à temática dos indivíduos loucos que cometem crimes e precisam retornar à liberdade após tratamento psiquiátrico obrigatório sob regime de custódia.

A temática da sociologia do crime se manteve como um campo fértil durante todo o século $\mathrm{XX}$, mas se desenvolveu mais a partir do momento em que o direito especificou o fenômeno do crime a partir da punição (ROBERT, 2007). Philippe Robert (2007) demarca que a sociologia determinou o crime como objeto de estudo por meio do agrupamento de três temas principais: a tipificação, a transgressão e a repressão penal. No entanto, foi com as contribuições de Foucault para o estudo do aprisionamento como objeto sociológico em um panorama de explicação fundamentado em condições estruturantes das sociedades capitalistas modernas que o estudo da prisão, do delinquente, do louco criminoso, da repressão, do disciplinamento da prisão e da psiquiatria ganhou novos contornos para a produção de conhecimento nas ciências sociais. Foucault não só provocou um deslocamento nos estudos da prisão e das tecnologias punitivas, ao articulá-las dentro do espectro de produção de saber/discursos de poder, mas, principalmente, empreendeu um esforço de descrição das 
tecnologias punitivas como fenômenos intrínsecos às sociedades contemporâneas demarcadas pelas instituições disciplinares, que produzem efeitos de sentido específicos sobre os corpos dos indivíduos.

Uma das principais contribuições dos estudos foucaultianos sobre os fenômenos da prisão e da punição foi elucidá-los a partir da lógica de funcionamento das sociedades capitalistas modernas, em seus traços indistinguíveis que ultrapassam a constituição em si da prisão. Ao desvendar que as práticas disciplinares eram inerentes também a outras instituições, como escola, fábrica e exército, Foucault (1977) conseguiu criar uma das chaves explicativas mais intrigantes, no campo das ciências sociais, sobre as sociedades contemporâneas. Ele postulou que as disciplinas servem ao funcionamento das sociedades capitalistas ao criar utilidade aos corpos dóceis, embora as condições que tornaram as práticas disciplinares possíveis ultrapassem as próprias características do ordenamento capitalista. A disciplina das escolas, dos internatos, das Forças Armadas, das fábricas e das prisões funciona desde que esteja engatada a outras instituições de vigilância, como a família e o Estado; tal disciplina se articula, principalmente, a formas de saber específicas capazes de fazer o poder sobre os corpos se estender no tempo, até o momento em que o controle sobre eles não seja mais necessário e a disciplina ocorra naturalmente, de forma virtual, por meio da vigilância contínua. Sendo assim, o saber produzido justifica o poder que põe em ação novos saberes e toda uma série de dispositivos de leis, direitos, regulamentações, práticas para institucionalizar o saber/poder (VEYNE, 2011). Essas premissas são fundamentais para a compreensão do surgimento e da reprodução dos esquecidos dos manicômios judiciários brasileiros.

1.1.1 Disciplinas, família e instrumentalização dos membros familiares para o capitalismo

Cada sociedade elege seus atos puníveis e as consequentes formas de punição. Um conjunto mais ou menos reconhecível de princípios e fundamentações nas sociedades justifica a eleição dos atos puníveis e os sistemas punitivos. Assim como um conjunto de princípios e fundamentações é também responsável por designar aqueles indivíduos que não receberão punição, ainda que cometam atos infracionais. O lugar que a punição ocupa na estrutura social e as formas assumidas por ela podem representar aspectos mais elementares da formação de uma sociedade: seus traços culturais, institucionais, econômicos, históricos e políticos (GARLAND, 2008; RUSCHE; KIRCHHEIMER, 1999). 
Para estabelecer que as escolhas por sistemas de punição correspondem às realidades históricas e materiais, o materialismo histórico tentou de forma inaugural estabelecer algumas premissas gerais por meio dos estudos de Georg Rusche e Otto Kirchheimer (1999). Um dos principais objetivos de Rusche e Kirchheimer (1999) na obra Punição e estrutura social é descortinar os determinantes econômicos e políticos do direito penal e, sobretudo, o papel das instituições penais como instrumentos de domínio de classe, em que a penalidade expressa, simbólica e materialmente, o poder do Estado e suas configurações demarcadas por uma sociedade capitalista. Como não há textos específicos do marxismo sobre castigo e sanção penal, o estudo desses temas deriva do grande empreendimento marxista de inspiração dialética e materialista histórico.

É por meio de uma análise do desenvolvimento histórico das forças produtivas do capitalismo e de como são moldadas as instituições na superestrutura da sociedade que o estudo do direito penal acontece (RUSCHE; KIRCHHEIMER, 1999). Em sua grande parte, a obra Punição e estrutura social é uma narrativa de fatos desde a Idade Média até meados do século XX referentes ao modo como os métodos penais representam os valores e as práticas que organizam a produção material da vida em sociedade. Em contraste, por exemplo, com a perspectiva durkheimiana, que vê o castigo como fato social presente em todas as sociedades, a inspiração marxista de Rusche e Kirchheimer tende a considerá-lo como fenômeno específico determinado por formas históricas concretas. Ou seja, o modo como a sociedade organiza a produção dos meios materiais de sua existência tende a definir o castigo e as sanções penais. Há uma correspondência entre sistema de produção e organização penal.

Ampliando uma perspectiva iniciada em Durkheim de investigar o castigo como fenômeno além de seus conceitos jurídicos e determinantes funcionais ou de finalidade social, a perspectiva marxista sobre o castigo alerta que é preciso examiná-lo para além de seus fins de punição. É preciso localizar o castigo dentro da estrutura social que espelha os princípios gerais de funcionamento do capitalismo. Nesse sentido, é parte importante da obra Punição e estrutura social estabelecer eventos históricos que exemplificam como o sistema penal contemporâneo derivou de ações políticas de controle da vagabundagem, da mendicância, dos desempregados, dos trabalhadores inativos, ou seja, de todos os receptores de ajudas suscitadas pela pobreza. Políticas de controle dessa população, sobretudo seus princípios e técnicas, serviram de molde e foram levadas de uma instituição de controle a outra até se codificarem nos modernos sistemas de penalidade a que se tem acesso. 
A principal contribuição da perspectiva marxista no estudo da punição é apontar o ocultamento dos objetivos das práticas de controle e penalidade em instituições atuais: ou seja, o castigo praticado pelas instituições penais e de controle em sociedades capitalistas serviria para "beneficiar" a sociedade em geral, uma vez que seu interesse de fundo é penalizar os despossuídos, apoiando os interesses da classe dirigente e reafirmando os valores dessa classe. Grosso modo, há uma relação entre excedentes do mercado de trabalho e instituições penais que passam a ser o objeto central de intervenção das administrações penitenciárias em geral.

Foi a perspectiva de inspiração marxista que denunciou que as instituições penais têm um papel importante, embora secundário, de constituição dos valores em torno da força de trabalho para a sociedade capitalista de produção. Em termos marxistas, o castigo presente em sociedades pré-industriais e pré-capitalistas é decodificado, nos sistemas penais atuais, como uma valorização forçada e extenuante do trabalho como dignificante da condição humana, ocultando a exploração do trabalho pelo capital. Por um lado, o trabalho passa de uma condição meramente necessária à organização capitalista para uma condição essencial e principal da vida humana. Por outro, medidas radicais de controle, como poorhouses, workhouses, casas de correção e práticas de assistência social que penalizavam a pobreza, passaram a ser responsáveis por deixar disponíveis os pobres a um mercado de trabalho que explora a mão de obra. O objetivo de Rusche e Kirchheimer é, em grande medida, demonstrar como essa operação se dá e é espelhada nos sistemas penais contemporâneos.

Rusche e Kirchheimer alertam que a ideia de exploração da força de trabalho dos prisioneiros em oposição à forma de o carcereiro lucrar já existia no opus publicum na Antiguidade Clássica, uma punição para as classes subalternas que persistiu nos tempos medievais. Entretanto, o diferencial das instituições de correção e das penalidades acessíveis contemporaneamente é que a punição à vagabundagem e o tratamento dado ao trabalho como dignificante da realização humana passam a ser centrais. Há uma motivação essencial nos métodos de punição do novo modelo de encarceramento: não apenas fazer produtiva a própria instituição de punir, do ponto de vista do "detento ter que trabalhar", mas tornar todo o sistema penal parte do programa capitalista do Estado. Dessa forma, é possível estabelecer conexões que explicam as formas de punição a partir dos contextos políticos, econômicos e sociais que estruturam determinado arranjo social.

No Brasil, por exemplo, o Código Penal de 1940 é a principal referência para estabelecer os procedimentos de punibilidade sobre as infrações penais, além de evidenciar as 
situações, os atos e os indivíduos que não serão objeto de punição. O Código Penal de 1940, com seus pressupostos e objetivos, foi reflexo de ideias que estavam presentes nos debates jurídicos, políticos e sociais no momento de sua elaboração (CARRARA, 1998). Mesmo que, nos últimos setenta anos, tenha havido uma série de mudanças importantes a respeito de por que punir e como punir, os princípios que justificam a punibilidade no país ainda são, em grande parte, oriundos do espírito do Código Penal de 1940.

O indivíduo com doença ou deficiência mental não recebe uma sanção penal comum de restrição de liberdade pelo crime cometido, ou seja, é inimputável. Quando comprovada a doença ou deficiência mental no momento em que o indivíduo cometeu a infração penal, o indivíduo não é punido, mas submetido a um tratamento psiquiátrico obrigatório por tempo indeterminado, que pode ocorrer ou não em restrição de liberdade. A indeterminação da duração da medida de segurança ocorre em razão da cessação da periculosidade, um conceito jurídico psiquiátrico que avalia, conforme as manifestações da doença ou deficiência mental, a possibilidade de o indivíduo voltar a cometer infração penal (PERES; NERY FILHO, 2002). Assim, o tratamento psiquiátrico obrigatório deve levar ao fim da periculosidade e ao retorno do indivíduo ao convívio social, o que só ocorre quando a cessação da periculosidade é atestada por exames psiquiátricos e a saída é autorizada por juiz.

Mesmo como uma espécie de requisito para o tratamento obrigatório, a restrição de liberdade para casos de loucos que cometem crimes é recente na história da legislação penal brasileira (CARRARA, 1998). Antes de 1940, o indivíduo acometido de algum transtorno, deficiência ou doença mental que cometesse crime não recebia uma sentença de reclusão para apartamento do meio social (PERES; NERY FILHO, 2002). O primeiro código do Brasil, o Código Criminal do Império, de 1830, estabelecia que "não se julgarão criminosos os loucos de todos os gêneros, salvo se tiverem lúcidos intervalos e neles cometerem os crimes". Como loucura era sinônimo de ausência de razão, qualquer juiz era capaz de identificá-la sem auxílio de especialistas. O destino do louco que cometesse crimes era o tratamento obrigatório em Santas Casas ou com as famílias, dada a inexistência, naquela época, de asilos no país (ENGEL, 2001; MACHADO et al., 1978).

Entre o tratamento dos loucos que podia ocorrer no interior das próprias famílias durante quase todo o século XIX ou nos manicômios comuns e o tratamento em restrição de liberdade nos manicômios judiciários a partir de 1940, várias instituições e saberes surgiram no Brasil, principalmente para mediar a relação entre o louco infrator e a justiça. De certo modo, essas mudanças destituíram os poderes tradicionais da família sobre seus loucos. Isso 
ocorreu na medida em que houve, no tipo de resposta oferecida, um deslocamento do tema mais para a área de segurança pública e menos para a de assistência médica. Foi na virada do século XIX para o XX que a assistência oferecida aos loucos delinquentes pelas famílias ou pelos asilos começou a ser colocada em suspeição (CARRARA, 1998; ENGEL, 2001). Consequentemente, a necessidade de uma instituição diferenciada ao mesmo tempo da prisão e do hospital psiquiátrico surgiu nos debates públicos (CARRARA, 1998). Mas essa suspeição sobre o papel familiar na assistência e no controle dos loucos pouco tem a ver com a competência em si das famílias. As famílias continuariam a exercer papel importante nessa mediação, embora ocupando novas atribuições.

Essa relação da família com as atribuições de controle dos indivíduos e, mais especificamente, seu papel na transformação dos indivíduos em função das razões do Estado sempre esteve presente na formação política, econômica e socioinstitucional do país (COSTA, 1979). Segundo Jurandir Freire Costa (1979), inicialmente, a consolidação do Estado brasileiro e sua capacidade de interferir nos assuntos privados a fim de assumir atribuições como responsabilidades públicas encontrou nas famílias um dos mais fortes obstáculos à sua consolidação. Essa é uma das análises sobre a formação sócio-histórica e política do Estado brasileiro e vale a pena deter-se nela.

Durante o período colonial, a administração do país isolava-se no litoral e as famílias encontravam-se na zona rural. No final desse período, o surgimento das cidades aproximou esses opositores, o que tornou os conflitos perenes e cada vez mais desafiantes. De um lado, a força tradicional das famílias no suprimento das necessidades dos indivíduos, as relações de reciprocidade e a coesão entre seus membros representava uma ameaça para o reconhecimento, por parte dos indivíduos, do papel jurídico e centralizador do poder do Estado (COSTA, 1979). Por outro, o fortalecimento do Estado dependeu da capacidade dos governos coloniais, dos Impérios e da República Velha de controlar as cidades e as populações e de oferecer condições habitáveis aos centros urbanos.

Seja para conseguir a subordinação militar dos indivíduos, seja para resultar na cooptação deles à centralização do poder do Estado, era preciso sujeitá-los à ordem estatal no período colonial e imperial (COSTA, 1979). Instituições disciplinares, como escola e exército, eram incipientes na capacidade de ordenar os indivíduos e deixá-los à disposição para a lógica de pactuação e sustentação do Estado nacional. Foi com o uso da medicina - mais precisamente da medicina higienista - que a estratégia de fortalecimento do poder estatal fez uso do governo político dos indivíduos (COSTA, 1979). A medicina, em seu braço de 
higienização pública, recebeu a herança da oposição atomizada entre campo e cidade, entre indivíduo e governo, na incumbência de ser uma das estratégias de modernização do Estado brasileiro a partir do século XIX (MACHADO et al., 1978). No entanto, esbarrava frequentemente nos hábitos e costumes que replicavam a tradição familiar e agrária, o que fazia com que os indivíduos não se subordinassem automaticamente aos objetivos civis, políticos e jurídicos dos governos.

Em oposição à medicina tradicional, especulativa e rudimentar dos séculos XVI, XVII e XVIII, a medicina higienista passou a ter melhores instrumentos para atuar sobre a população (COSTA, 1979). Ao mesmo tempo, inseriu-se nas famílias representando o Estado em suas funções públicas de governo, levando adiante o seu principal interesse e desafio até então de controle das populações (COSTA, 1979). A higienização das populações como instrumento de sujeição política dos indivíduos forneceu uma das matrizes da estrutura familiar urbana no Brasil, segundo Jurandir Freire Costa. E, principalmente, dessa estratégia pode ter surgido o padrão de relações entre Estado, família e políticas públicas desde o final do século XIX e durante todo o século XX no país. No entanto, no processo de definição do modelo das famílias, a medicina higienista se dirigia apenas às famílias da elite (COSTA, 1979; ENGEL, 2001). Os escravos, mendigos, vagabundos e loucos eram os casos-limite da infração higienista (ENGEL, 2001). A esses grupos eram destinadas outras ações, mais severas, de apartação e normalização (LOBO, 2008), mas também o ideal da família burguesa que nascia dessa política governamental.

Jacques Donzelot (1973) mostrou como na França do século XIX a sujeição da família à disciplina da fábrica foi importante para a estruturação do capitalismo industrial e, ao mesmo tempo, para o nascimento da centralidade da família na sociedade moderna. Durante a formação do proletariado europeu, no século XIX, as condições extenuantes de trabalho, a habitação precária e o trabalho infantil e dos idosos tornaram cada vez mais frágeis as relações de família e invalidaram a formação da estrutura familiar no processo de urbanização e industrialização europeu. Os empresários, os filantropos, a igreja e os poderes públicos se uniram para reconstituir o tecido familiar da época medieval devastada pela industrialização (CASTEL, 1995; DONZELOT, 1973). As exigências para a formação do Estado moderno tinham acima de tudo a necessidade de um controle demográfico e político da população, voltado para finalidades específicas do processo de industrialização e urbanização.

Esse controle voltado para as famílias tinha o objetivo de disciplinar o cuidado dos filhos, controlar a pobreza e criar os braços disponíveis para o capitalismo industrial nascente. 
A medicina, de um lado, reorientando o papel das mulheres no lar para o cuidado das crianças e da higiene da família e, do outro, a moralização da pobreza, pela atuação da assistência social, filantropia e medicina, subordinaram os indivíduos, seus comportamentos e hábitos para conduzi-los à eficácia da urbanização e industrialização (CASTEL, 1995; DONZELOT, 1973). A normalização e a disciplina passaram a ser instrumentos do Estado no controle das famílias na Europa a partir do século XIX.

Há um lapso temporal entre esses acontecimentos na Europa e no Brasil, dado que a industrialização brasileira só foi ocorrer nas primeiras décadas do século XX (DECCA, 1983). No entanto, esse modelo de relações entre Estado, famílias e medicina é possível de ser verificado no país. A higiene da elite familiar brasileira seguiu esse padrão durante o século XIX e, com o início da industrialização, as medidas normalizadoras e disciplinadoras dos indivíduos se intensificaram (COSTA, 1979; DECCA, 1983; MACHADO et. al, 1978). O sentimento moderno em torno do padrão familiar resultou de um empreendimento da normalização médica da família em estreita correspondência com o desenvolvimento urbano e a criação do Estado nacional brasileiro (COSTA, 1979; MACHADO et al., 1978). A disciplina forjada para as famílias serviu a esse empreendimento, paralelamente ao fortalecimento do padrão familiar burguês no Brasil, inspirado na Europa.

Sobre as disciplinas, Foucault (1977) realiza uma genealogia do poder disciplinar em sua relação com as famílias e, ao que interessa nesta tese, com o saber psiquiátrico. Em Vigiar e punir (1977) e em O poder psiquiátrico (2006), Foucault caracteriza o que ele chama de sociedade disciplinar. As disciplinas são métodos que permitem o controle minucioso das operações do corpo, que realizam a sujeição constante de suas forças e lhes impõem uma relação de docilidade e utilidade. Inaugurando uma nova compreensão da história das ideias nas ciências humanas, Foucault (1977) demonstra que a principal característica das instituições nascidas na modernidade é que elas cumprem funções disciplinares, ao docilizar os corpos, tornando-os úteis ao sistema de produção. Dessa forma, fábricas, escolas, exércitos, prisões, clínicas e manicômios são instrumentos de docilização dos corpos, tornando-os úteis.

As disciplinas são técnicas difundidas em larga escala no século XIX, mas iniciadas em instituições religiosas e militares nos séculos anteriores, tornando-se a forma geral na modernidade do contato sináptico entre o poder político e o corpo individual (FOUCAULT, 1977). Para Foucault (1977), não é possível analisar o funcionamento da psiquiatria limitando-se à instituição asilar, pois é a partir do poder disciplinar que se compreende o 
mecanismo psiquiátrico. Desse modo, as disciplinas seriam táticas, ou seja, maneiras de fazer o poder funcionar sempre articulado ao saberes.

Foucault (1977) contrasta o poder disciplinar da época moderna ao poder de soberania predominante no período medieval. Poder de soberania era uma relação de poder predominante durante toda a Idade Média, por relações absolutistas, nas quais havia uma vinculação do soberano com os súditos numa extensão de poder assimétrico, na confiscação de produtos e na aquisição, pelos senhores, de valores produzidos pelos servos. O poder de soberania era caracterizado com uma marca de anterioridade fundadora, ou seja, a relação de soberania se estabelecia a partir de um ato originário, como um direito divino, uma conquista, uma vitória, um ato de submissão ou um juramento de fidelidade, principalmente num ato firmado em que o soberano concedia privilégios, ajuda e proteção. Outro traço do poder de soberania é que ele era atualizado ou reforçado por cerimônias e rituais: relatos, sinais, gestos, hábitos, obrigações de cumprimento, sinais de respeito e insígnias são constitutivos de um arsenal que garante a perpetuação fortalecida do poder de soberania (FOUCAULT, 1977). Um efeito desse tipo de poder é que as relações de soberania não são destinadas a um corpo individual, mas a uma multiplicidade que está acima da individualidade, tais como os súditos, agrupamentos familiares e camponeses.

Em contraste ao poder de soberania, o poder disciplinar é uma apropriação do tempo e do corpo dos indivíduos. No poder disciplinar, não há meramente uma apropriação para fins de confisco de produtos e valores em relações assimétricas, como se dava na Idade Média entre os soberanos e os súditos, entre os senhores feudais e os camponeses (FOUCAULT, 1977). Se o poder de soberania tem o olhar voltado para o passado, para os laços que garantiram a sua existência originária, o poder disciplinar tem o olhar voltado para o futuro, para o momento em que o corpo sujeitado funcionará sem a vigilância da disciplina, em que a vigilância será não mais que virtual, em que as disciplinas se tornarão um hábito (FOUCAULT, 1977). Por conseguinte, o que garante o poder disciplinar, o seu perpetuamento, é o exercício progressivo, as técnicas disciplinares e de vigilância voltadas para o aperfeiçoamento contínuo do controle dos corpos.

Ao contrário do poder de soberania — que só intervinha violentamente nos momentos de punição para fazer valer sua força desproporcional, para evidenciar seu poder absoluto no poder disciplinar, o par formado pela vigilância e punição se dá desde os primeiros momentos, antes do aparecimento do primeiro ato que levará à punição. Isto é, em sociedades de predomínio do poder disciplinar, uma característica fundante é a ação precoce desse poder, 
por meio de um jogo de vigilância, recompensas e aprendizados, em uma série de instituições infrajudiciárias surgidas para fazer o poder disciplinar funcionar nos corpos antes de a punição severa ocorrer nos meios judiciários (FOUCAULT, 1977).

De acordo com Foucault (1977), para a acumulação do capital, foi preciso a acumulação dos homens cuja técnica de distribuição das singularidades, para retirar a eficácia produtiva máxima de seus corpos, deveu-se às disciplinas. As disciplinas consistem em maximizar a utilização possível dos homens não para usar todos eles no capitalismo. É exatamente para não utilizar todos, para não ampliar ao máximo o mercado de trabalho que recorre à força dos corpos, que as disciplinas organizam as disposições dos indivíduos (FOUCAULT, 1977). Portanto, uma das funções principais do poder disciplinar é realçar a eficácia desses corpos produtivos, criando mecanismos institucionais de vigilância e disciplina contínuas.

No entanto, a hierarquização dos corpos, das habilidades e das práticas corporais tão presentes no poder disciplinar faz surgir, ao mesmo tempo, os corpos impossibilitados de classificar, hierarquizar e disciplinar. Há indivíduos que não se submetem às disciplinas. Estes serão o resíduo, o irredutível, o inclassificável, que gera constantemente a necessidade de novas instituições, saberes e práticas capazes de recuperar esses corpos inassimiláveis pelas disciplinas (FOUCAULT, 2006). O desertor é o inassimilável dos exércitos, o débil mental é o inassimilável das escolas, o delinquente é o inassimilável das instituições punitivas, e assim por diante. E, principalmente, para Foucault (2006), o doente mental é uma espécie de resíduo de todos os resíduos, é o caso-limite dos inassimiláveis: é inassimilável por todas as instituições disciplinares.

Nessa necessidade de recuperar os indivíduos que não se submetem às disciplinas, o surgimento de instituições disciplinares ocorre de modo infinito (FOUCAULT, 2006). É o caso do sistema educacional que inventa instituições para recuperar aqueles não assimilados pela disciplina da escola, é o caso das instituições punitivas que criam ramificações de recuperação dos delinquentes que não foram assimilados e recuperados pela disciplina da prisão. É nesse sentido, na teoria foucaultiana, que a família exerce papel fundamental. Nas palavras de Foucault, a família "é em todo o caso uma espécie de cela dentro da qual o poder que se exerce não é, como se costuma dizer disciplinar, mas, ao contrário, é um poder do tipo soberania" (2006, p. 79). No funcionamento da família, é possível verificar vínculos de compromisso e dependência, vínculos contratuais ou de propriedade, ou compromissos afetivos estabelecidos no casamento ou no nascimento, cuja referência ao ato anterior de 
fundação da família dá solidez a ela. Essas características fazem da microfísica de poder presente nas famílias a característica de poder de soberania, e não do tipo disciplinar.

A família seria um elo entre os indivíduos e os dispositivos disciplinares. Ela mesma não funciona como dispositivo disciplinar, pois liga os indivíduos às instituições e práticas responsáveis por retirar dos corpos a força máxima para o disciplinamento e os comportamentos que cumprem expectativas específicas do ordenamento social. No caso dos indivíduos em medida de segurança, o papel da família é estruturante para fazer o louco que comete crimes circular entre os aparelhos disciplinares: desde as primeiras tentativas de remeter o indivíduo à disciplina das escolas, dos exércitos, dos sistemas de assistência em saúde, sejam manicomiais ou em meio aberto, e dos aparelhos de polícia, no caso da perturbação da ordem, até o ingresso nos sistemas punitivos, como delegacias, penitenciárias e manicômios judiciários.

Entretanto, Foucault destina à família o modelo de microfísica de poder de soberania, não no sentido de relegar à instituição familiar resquícios do poder de soberania do Antigo Regime, o que seria um contraste evidente nas sociedades atuais regidas pelo poder disciplinar. O fato de a microfísica da soberania funcionar no interior das famílias não é porque, porventura, teriam sobrado resquícios do poder e das práticas da soberania do período medieval. Ao contrário, um poder de soberania diferenciado está na constituição familiar atual justamente por ela ser uma engrenagem essencial ao sistema disciplinar (FOUCAULT, 2006). É a família, como instância de coerção do tipo soberano, que torna seus membros disponíveis aos sistemas disciplinares. Ela define quando, como e por que seus membros serão transferidos aos sistemas disciplinares.

De algum modo, a família forte e soberana da idade medieval foi transformada pelos saberes e técnicas da sociedade moderna, industrial e capitalista que se intensificou a partir do século XIX (FOUCAULT, 2006). O resultado foi que se destinou à família uma microfísica de soberania que complementa e reforça as funções das instituições disciplinares (FOUCAULT, 2006). Em sociedades como as atuais, regidas pela microfísica disciplinar, a família não foi dissolvida pela disciplina: o poder das famílias sobre seus membros, na verdade, se intensificou no sentido de ter se concentrado e limitado ao mesmo tempo em que assumiu o papel central de disponibilizar, aos sistemas disciplinares da educação, do trabalho, do militarismo e das instituições corretivas e punitivas, os indivíduos a serem disciplinados e docilizados. 
Para Donzelot (1973), essa mudança na atribuição das famílias se deu na virada do período medieval para a era industrial, em que a busca pela harmonia entre a ordem das famílias e a nova ordem estatal no capitalismo foi mais um produto de conveniência tática do que de aliança estratégica. A percepção da desagregação dos membros da família em razão da nova ordem urbana e industrial era diferente para as famílias e para o Estado. Para as famílias, os desafios enfrentados pelos novos tempos era em razão dos filhos adulterinos, dos menores rebeldes, das moças que se transformavam em prostitutas nas cidades nascentes, onde não tinham emprego, da pobreza e dos demais inimigos da honra das famílias. Já para o Estado, era ao desperdício de força de trabalho, aos indivíduos inutilizáveis ou inúteis que se precisava responder com estratégias de recuperação da força requerida pelo capitalismo industrial (DONZELOT, 1973). Nesse sentido, os hospitais gerais, as workhouses, os conventos e os hospícios serviram de base estratégica para uma série de intervenções corretivas sobre a vida familiar, com uma mobilização estatal, filantrópica e religiosa que buscou reorganizar a família popular em função dos imperativos econômicos e sociais (DONZELOT, 1973). Foi, portanto, desde o final do século XIX que esse padrão de relação entre forças estatais, filantrópicas e religiosas estabeleceu laços entre assistência social e trabalho no sentido de recuperar os braços para o capitalismo industrial. Foucault aprofundou esse modelo analítico ao tentar introduzir a genealogia do poder disciplinar.

Ao longo do século XIX, a família, uma espécie de reduto do poder de soberania, foi submetida a esse empreendimento de readequação de suas funções de acordo com a ordem econômica e social imposta pelo capitalismo industrial. Uma das consequências desse empreendimento foi a função adquirida pelas famílias de, apesar de se localizar externamente ao sistema disciplinar, responder às instituições disciplinares por meio da produção e reprodução de seus membros familiares. A família é uma instância de solidez de sociedades do tipo disciplinar (FOUCAULT, 2006). Foucault mostra que, ao lado dessa função, e também na empreitada de recuperar as famílias e seu papel de submeter seus membros aos sistemas disciplinares, surge uma série de instituições durante o século XIX que terão por função combater o enfraquecimento da família.

O surgimento de abrigos para crianças, idosos e loucos, bem como de instituições corretivas para os jovens delinquentes, os novos papéis da filantropia e a emergência da assistência social passarão a ter por função primordial constituir uma rede de instituições disciplinares que substitui a família, ao mesmo tempo em que a fortalece (FOUCAULT, 2006). O funcionamento dessas instituições ocorre em sintonia com as atribuições da família, 
a ponto de, quando uma dessas instituições falha no cumprimento de suas funções, é às famílias que os indivíduos inassimiláveis pelas instituições disciplinares retornam. Portanto, as instituições disciplinares docilizam os sujeitos, mas os reforçam e refamiliarizam, isto é, criam condições para que eles retornem às famílias sem constituir uma ameaça a elas. No caso da psiquiatria, a função dos manicômios nada mais é do que uma empreitada institucional para restabelecer as condições de o indivíduo se refamiliarizar. No momento em que o indivíduo louco representa uma ameaça à coesão familiar, as famílias o entregam a esses dispositivos disciplinadores, que têm como finalidade o sujeito normalizado, docilizado e útil.

1.1.2 Liberdade, tutela e cidadania na loucura: o papel da assistência e da saúde mental

Na Europa, na virada do século XVIII para o XIX, o fim do Antigo Regime e o surgimento de valores que fundavam a Idade Moderna trouxeram elementos novos para as respostas dadas ao tema da loucura nos países europeus. Robert Castel (1978) analisa o caso francês, mas pontua que a realidade francesa se assemelha à de vários outros países. A partir do século XIX, a resposta psiquiátrica foi montada em conjunto com uma prática assistencial asilar para os alienados: a psiquiatria não decorreu de uma evolução e especialização da ciência médica, mas de uma consequência da assistência pública para normalizar indigentes, pobres, desempregados, vagabundos e loucos (CASTEL, 1978). De repente, a sociedade do contrato, fundada nos direitos e deveres entre cidadãos livres e iguais e, principalmente, sujeitos produtivos, se viu desafiada pelo tema da loucura, em que os indivíduos acometidos de enfermidades mentais não se enquadravam nos pressupostos do indivíduo esclarecido, produtivo e independente do Iluminismo - em outras palavras, do projeto liberal-burguês. Isto é, o louco não tinha a capacidade de reciprocidade e produtividade necessária para as trocas com a coletividade que sustentam o contrato na sociedade moderna.

Castel demonstra que a Revolução Francesa que rompeu com o Antigo Regime, com o poder tradicional monárquico, rompeu também com o equilíbrio do controle dos comportamentos desviantes, antes operado pelo poder real, principalmente pelo mecanismo das lettres de cachet (CASTEL, 1978). As lettres de cachet representavam a autorização do rei para determinar a restrição de liberdade de indivíduos que precisavam de internamento por motivo de loucura. Foi a partir desse movimento que se construiu, aos poucos, uma política direcionada à loucura que culminaria na lei francesa de 1838, que instituiu o regime de tratamento dos alienados. Esse novo modelo regulador da loucura substituiu o poder real pelo 
da justiça e da administração; ao mesmo tempo, centralizou no asilo o corpo de profissionais, técnicas e saberes do controle da loucura como doença. Assim, o saber psiquiátrico como alienismo nasceu simultaneamente ao nascimento do asilo para receber o louco.

Para Castel (1978), a psiquiatria exerce a função de administrar a loucura transformando-a numa questão, acima de tudo, técnica. $\mathrm{O}$ alienismo e seu modelo de internação "representaram a versão medicalizada da concepção segregativa da assistência" (CASTEL, 1978, p. 273). O papel que a psiquiatria exerceu, ao longo do século XIX, respondeu à própria lógica da sociedade contratual, que anuncia o louco como incapaz, como irresponsável, como refratário à lógica do trabalho — portanto, como alguém que precisa ser protegido, tutelado. A psiquiatria oferece, por meio da técnica asilar, a possibilidade de administrar os inassimiláveis, os desajustados, os loucos, sujeitando-os às normas de uma sociedade produtiva constituída de indivíduos racionais e aptos para a produção. Mas, para essa sujeição ocorrer, a tutela dos loucos por meio do asilo antecipou em quase cinquenta anos a assistência pública aos pobres como proteção no capitalismo gerador de pauperismo (CASTEL, 1978). A tese de Castel é que essa antecipação foi pelo fato de o louco representar uma ameaça à sociedade contratual.

No caso brasileiro, o hospício foi criado pelo Decreto Imperial de 1841 e inaugurado em 1852 (ENGEL, 2001). Embora inspiradas na experiência francesa, onde a origem histórica da psiquiatria era decorrência da constituição do asilo, as respostas aos problemas colocados pela loucura no Brasil foram resultado do regime monárquico (ENGEL, 2001). O tema da proteção ao louco se colocava dentro de um enquadramento da caridade aos desvalidos, do isolamento dos loucos arruaceiros que ameaçavam a ordem pública, fazendo uso de práticas caritativas, longe ainda de decorrer de um contrato social de afirmação de proteção ao indivíduo incapaz para a ordem do trabalho e para a ordem burguesa (ENGEL, 2001). Para Pedro Gabriel Delgado (1992), o desafio colocado pela loucura à sociedade do contrato, no Brasil, só poderia se configurar a partir do Decreto de 1903, que criou o regulamento da assistência a alienados, no início do período republicano. Desse modo, assim como na França, a assistência aos loucos antecipou a assistência pública aos pobres — no caso brasileiro, também em quase cinquenta anos —, dado que as ações da assistência social foram estruturadas a partir da criação da Legião Brasileira da Assistência Social, em 1942 (SANTOS, 1979).

Delgado (1992) buscou demonstrar como ocorreu a articulação entre a psiquiatria e o direito para a determinação da cidadania na loucura no Brasil. Seu trabalho foi profundamente 
marcado pelos princípios e valores que orientaram a luta antimanicomial no país, que iniciou no final dos 1970, cresceu nos anos 1980 e 1990 e culminou com a aprovação da chamada Lei da Reforma Psiquiátrica em 2001, a lei 10.216 (BRASIL, 2001). O objetivo de Delgado (1992) foi o de percorrer historicamente e investigar como saberes e práticas da psiquiatria e da justiça dialogaram para estabelecer ou não o estatuto de cidadania dos loucos, principal reivindicação do Movimento da Reforma Psiquiátrica. É possível apreender da obra do autor que a afirmação dos direitos dos loucos contemporaneamente não pode prescindir de uma investigação de como saberes dialogaram em diferentes momentos históricos, acompanhando as mudanças das respostas dos governos, da psiquiatria e da justiça à questão da loucura e às práticas da tutela, da assistência, da interdição e da punição aos indivíduos loucos.

O dispositivo da interdição, comumente empregado em casos de loucos considerados, principalmente, por suas famílias como incapazes de gerir a própria vida, ganhou uma análise profunda na obra de Delgado. Por meio da análise de documentos históricos, leis e peças judiciais, ele concluiu que a interdição por motivos psiquiátricos serve para outras finalidades sociais, além da proteção das pessoas incapazes de cuidar ou de gerir suas vidas (DELGADO, 1992). Uma série de regulações de interesses familiares, administrações de bens e recursos dos loucos, restrição à participação na riqueza familiar, ou seja, exemplos extremos de violação de direitos fundamentais dos loucos fundamenta grande parte das interdições a pedido dos familiares. Delgado articula essas consequências da interdição ao modelo de tutela do indivíduo louco predominante no Brasil até os anos 1980. É da ausência do reconhecimento da cidadania do indivíduo louco que o paradigma da tutela estrutura a relação entre justiça e loucura, destituindo do indivíduo louco o status de cidadão (DELGADO, 1992). Em busca da desregulamentação desse modelo da tutela, o Movimento da Reforma Psiquiátrica buscou articular novas respostas à questão da loucura, promovendo a cidadania do indivíduo louco.

Tanto para Castel quanto para Delgado, a tutela que, por um lado, promove assistência aos sujeitos improdutivos, mas por outro, restringe a participação do indivíduo louco na vida social é decorrência de um modelo assistencial psiquiátrico montado em torno do asilo para responder ao impasse do indivíduo louco improdutivo que não faz parte da sociedade do contrato (CASTEL, 1978; DELGADO, 1992). A assistência psiquiátrica que tem como predomínio o modelo manicomial, voltado para a apartação social dos loucos como modalidade profilática das agruras do sofrimento mental, gera consequências deletérias para a vida do indivíduo, conforme demonstrado pelos autores. O efeito da tutela nesse modelo é o 
paternalismo, que institui uma relação institucional de dominação para controle dos loucos, mas sob a prerrogativa da assistência necessária e benfeitora.

Castel (1978) conclui seu livro dizendo que é depois do modelo do asilo e da tutelarização que surge a psiquiatria tal como conhecemos contemporaneamente, que considera a loucura como uma doença e que busca nas manifestações dos transtornos uma lesão constitutiva, aproximando-se assim da medicina com tendências organicistas. Por sua vez, Delgado conclui seu livro apontando que a reforma psiquiátrica se empenhou no Brasil para reverter essa tutelarização que destitui o status de cidadania e impossibilita o desenvolvimento de uma vida social com sentido na loucura; para isso, abriu os portões dos manicômios, oferecendo assistência psiquiátrica em serviços de base comunitária e de não apartação social.

Estabelecer uma analogia para compreender as instituições disciplinadoras e normalizadoras da sociedade atual não deve significar "dissimular o antagonismo de princípio entre o direito de punir e o dever de dar a assistência" (CASTEL, 1978, p. 38). A relação entre família, psiquiatria, justiça e indivíduo louco sempre esteve às voltas com os desafios da garantia da cidadania na loucura, cujo experimento do asilo é o melhor exemplo da resposta que inviabiliza a participação do louco na vida cotidiana da comunidade. No Brasil, a Lei 10.216, de 2001, buscou promover alternativas para a assistência médica diferentes das da resposta asilar (BRASIL, 2001). Por outro lado, o direito à assistência social firmado na Constituição Federal de 1988 visa à garantia de necessidades básicas aos indivíduos, independente de sua capacidade produtiva (BRASIL, 2004b). Entretanto, em meio à assistência social e à política de saúde mental no modelo antimanicomial, a assistência aos indivíduos com doença ou deficiência mental que cometem crimes ainda figura primordialmente como da alçada da segurança pública.

A família, portanto, é a instituição que engatará os seus membros nos sistemas disciplinares para fins de docilização dos corpos e maximização de sua utilidade. No caso do louco, a disciplina psiquiátrica servirá também para refamiliarizar o indivíduo para que a convivência não se constitua em ameaça à dinâmica familiar. Por outro lado, o fenômeno da tutelarização foi a resposta ao anacronismo provocado pela loucura nas sociedades modernas do tipo contratual: o sujeito improdutivo precisa ser protegido, inclusive, para fazer valer os valores dessas sociedades (CASTEL, 1978). A assistência social, como nas palavras de Foucault, que "tem por função constituir uma espécie de tecido disciplinar que vai substituir a 
família" (1974, p. 105) cumpre a função de garantir proteção às necessidades do indivíduo improdutivo em uma sociedade pautada por produção, individualismo e independência.

No Brasil, a assistência social é hoje um tema comumente tratado como uma reivindicação na esfera dos direitos, em especial dos direitos humanos e sociais. No entanto, a história da assistência social nem sempre foi abordada nessa perspectiva. Durante quase todo o século XX, a assistência era matéria privada, filantrópica ou de práticas caritativas da igreja católica. Apenas a partir dos anos 1980 a ideia da assistência como política pública começou a se estabelecer até ser firmada na Constituição Federal de 1988 como direito de seguridade social (BOSCHETTI, 2006; TAVARES, 2008). Foi estabelecida a assistência social como componente da seguridade social, ao lado da saúde e da previdência social. Além disso, foi garantida no artigo 203 da Constituição uma renda mensal às pessoas idosas e deficientes que, em razão da pobreza, não pudessem manter sua sobrevivência ou tê-la suprida pelo grupo familiar. A norma constitucional assinalada no artigo 203 foi regulamentada pela Lei Orgânica da Assistência Social, em 1993 (BRASIL, 1993).

No entanto, os avanços da assistência social nos últimos anos, principalmente a partir de 2004, não foram capazes de desonerar o papel das famílias na provisão de bens e serviços ligados à assistência e ao cuidado de seus membros (PEREIRA, 2006a). São comuns situações de cuidado de crianças, pessoas com deficiência, pessoas com doença mental e idosos atendidos exclusivamente pela atuação das famílias (DINIZ; SQUINCA; MEDEIROS, 2006). Sem atenção de políticas sociais, a assistência e o cuidado oferecido pelas famílias, mais especificamente pelas mulheres, é um fenômeno que aprofunda as desigualdades no interior das famílias e fragiliza a autonomia de quem oferece o cuidado e de quem o recebe. No caso dos indivíduos em medida de segurança, a situação se agrava pelas dificuldades das famílias em oferecer cuidados específicos que a situação exige, além do fato de os crimes cometidos por esses indivíduos serem, em muitos casos, contra membros de seu grupo familiar, o que pode ser um obstáculo para o retorno do indivíduo a esse ambiente.

\subsection{Governamentalidade e dispositivos de segurança: o espírito do familismo que vai da segurança pública à assistência}

No momento em que, nos fins do século XIX, a assistência oferecida pelas famílias aos indivíduos loucos que cometem crimes foi destituída e ficou a cargo do Estado brasileiro a responsabilidade por guardar e cuidar deles, novos saberes e práticas surgiram e se articularam. A República brasileira, iniciada em 1889, decretou o novo Código Penal em 
1890. Nele, não eram criminosos os que possuíam "imbecilidade nativa e enfraquecimento senil", ou seja, aqueles que se achassem, nos termos do código, "em estado de completa privação de sentidos e de inteligência no ato do crime" (PERES; NERY FILHO, 2002). A mudança foi que os loucos passaram a ser inimputáveis e seus atos de infração não eram mais considerados crimes. O Código Penal da República estabeleceu também o local para onde os loucos que cometessem infrações seriam destinados para a segurança do público: os hospícios de alienados, recém-criados em algumas das maiores cidades do país.

O conceito amplo de loucura como "completa privação de sentidos e inteligência" passou a receber críticas na virada do século XIX para o XX, pois os crimes dos alienados eram apontados como os mais perigosos tanto por psiquiatras quanto por políticos e juristas (BARRETO, 2003; CASTRO, 1894; PERES; NERY FILHO, 2002). Tais críticas ressoavam principalmente a necessidade de delimitar o sentido da loucura e o papel dos médicos peritos para defini-la. Além disso, ganhou força a ideia de que os manicômios não eram suficientes para os loucos que cometessem crimes, surgindo a necessidade de alas penais dentro dos hospitais psiquiátricos (CARRARA, 1998). Cinquenta anos depois, no Código Penal de 1940, o louco passou a ser isento de pena desde que, por "doença mental, desenvolvimento retardado ou incompleto estivesse inteiramente incapaz de entender o caráter criminoso no momento do ato ou de determinar-se de acordo com este entendimento". Desse modo, o Código de 1940 inaugurou as medidas de segurança.

É importante compreender que, às críticas do direito, da nascente psiquiatria e do Código Penal de 1890, o Código Penal de 1940 respondeu cinquenta anos depois. Uma das principais críticas ao antigo Código Penal dizia respeito à definição de imputabilidade com base na doutrina clássica do livre-arbítrio. Era muito criticado por juristas o fato de o Código Penal de 1890 ter-se utilizado apenas do critério de responsabilidade moral para determinar a inimputabilidade penal (BARRETO, 2003; CASTRO, 1894; PERES; NERY FILHO, 2002). Por exemplo, no caso dos crimes cometidos pelos loucos, como havia ausência de livrearbítrio pela doença mental, não havia responsabilidade jurídica pelo crime. O que os críticos apontavam era que, mesmo ausente o livre-arbítrio, deveria haver outros critérios para a imputação penal, como a "defesa social” para a proteção da sociedade dos atos criminosos (BARRETO, 2003; CASTRO, 1894). Surgia assim a ideia de que a sociedade tinha o direito de se proteger do louco que comete crimes.

A crítica da psiquiatria ao antigo Código Penal era de que o artigo que determinou a inimputabilidade em razão da loucura desconsiderou a noção de loucuras parciais, de loucuras 
sem delírio; noções estas já crescentemente adotadas pela psiquiatria europeia e conhecidas por especialistas no país na época (MOREIRA; PEIXOTO, 2001; CARRARA, 1998). Essa desconsideração pelo texto do Código Penal de 1890 fez surgir em seus críticos, incluindo os juízes, algo a que o próprio direito penal resistiu durante muito tempo: a necessidade de perícia médica como auxiliar ao diagnóstico da loucura em casos de crime (PERES; NERY FILHO, 2002). Inicialmente, os juízes reivindicavam perícia médica, sem ser psiquiátrica, uma vez que a psiquiatria ainda se consolidava no país como um campo do conhecimento. Foram principalmente a essas duas lacunas no antigo Código Penal, uma relacionada ao direito e outra à psiquiatria, que as medidas de segurança por tempo indeterminado fixadas pelo critério de periculosidade responderam no texto do Código Penal de 1940.

Em pouco mais de cinquenta anos, a resposta do direito penal e da medicina à questão dos loucos que cometiam crimes se modificou do mero tratamento em asilos e nas famílias para o tratamento por tempo indeterminado que pode ocorrer em restrição de liberdade. Nessa modificação, três novidades apareceram: os casos dos loucos que cometem crimes passaram a ser o único momento no direito penal em que os juízes não são os principais agentes que decidem o destino dos infratores, pois a responsabilidade do louco pelo ato criminoso é determinada com base em avaliação psiquiátrica que liga o crime à doença mental. O Novo Código Penal de 1940 especificou as atribuições dos juízes, que passaram a ser os responsáveis por buscar no histórico dos delinquentes as motivações para os atos criminosos; porém, nos crimes cometidos por loucos, os juízes têm o auxílio dos psiquiatras (PERES; NERY FILHO, 2002).

A segunda novidade no direito penal sobre a punibilidade da loucura foi a noção de periculosidade, inexistente até então no direito penal brasileiro, aparecendo no artigo 78 do Código Penal como a probabilidade de o criminoso voltar a delinquir. Mas, junto da periculosidade dos loucos, o artigo 78 especificou que os perigosos eram também os indivíduos condenados por crime cometido em estado de embriaguez, por álcool ou substância de efeitos análogos, os reincidentes em crime doloso e os condenados por crime que hajam cometido como filiados a associação, bando ou quadrilha (BRASIL, 1940). No caso do louco, a periculosidade é avaliada por perícia médica para determinar a duração da medida de segurança.

A terceira novidade foi a destinação dos manicômios judiciários como o local para cumprimento das medidas de segurança. Existentes juridicamente desde 1903, mas efetivamente em funcionamento em 1920 para os "degenerados" criminosos, os manicômios 
judiciários se constituíram em uma instituição híbrida da justiça e da psiquiatria para tratamento dos inimputáveis em restrição de liberdade (CARRARA, 2010). Curiosamente, os manicômios surgiram como destinação para os loucos que cometem crimes antes mesmo de ter sido estabelecido no Código Penal, o que só ocorreu em 1940. A primeira vez que se mencionaram na legislação os manicômios judiciários foi em 1903, na Lei da Assistência Médico-Legal a Alienados (CARRARA, 1998; ENGEL, 2001). Essas três novidades no Código Penal de 1940 tinham estreita relação, por um lado, com o fortalecimento do saber psiquiátrico no Brasil e a crescente reivindicação, por esse campo, do tema da loucura e do crime como sendo de sua alçada científica (CARRARA, 1998); e, por outro, com mudanças dentro do direito penal sobre o tema da loucura e do crime, principalmente por influência de debates na área da criminologia que ocorriam na Europa.

O que permitiu essa série de mudanças em pouco mais de cinquenta anos na legislação penal brasileira sobre o caso dos loucos que cometem crimes? É possível explorar que a legislação penal estabelecida em 1940 recebeu influências de experiências e de anseios presentes na sociedade, principalmente sobre a necessidade de postular princípios que protegessem sua própria constituição como corpo social, dado o momento de formação da sociedade urbana, industrial e capitalista (COSTA, 1979; CUNHA, 1986). Desse modo, com o texto do Código Penal de 1940, foi possível chegar ao fim de uma disputa travada desde o final do século XIX por juristas e psiquiatras que postulavam que defender a sociedade da loucura estava acima de deixar o louco isento de punição pelo crime cometido, como era desde o primeiro Código Penal brasileiro, de 1830 (PERES; NERY FILHO, 2002). Na Lei de Execuções Penais de 1984, a periculosidade deixou de ser um princípio para determinar o afastamento de qualquer indivíduo do meio social. Porém, ainda ficou restrita aos inimputáveis por doença ou deficiência mental, devendo ser avaliada a fim de investigar as condições de retorno ao convívio social do indivíduo em medida de segurança.

Os anseios sociais que resultaram na criação das medidas de segurança dizem respeito a uma forma diferenciada de compreender o tema da loucura. Pois, da segunda metade do século XIX até as primeiras décadas do século XX, esse tema ganhou sensibilidade social no país. Surgiram várias instituições destinadas à internação dos loucos, todas elas concentradas na parte mais desenvolvida do país, nas regiões Sul e Sudeste: o Hospício Pedro II, na então capital Rio de Janeiro, inaugurado em 1852, o Hospital Psiquiátrico São Pedro, em Porto Alegre, fundado em 1884 e inaugurado em 1903, a Colônia Agrícola de Juquery, em São Paulo, em 1898, e o Hospital Colônia de Barbacena, em Minas Gerais, em 1903 (ENGEL, 
2001; MACHADO et al., 1978). O louco e sua liberdade passaram a ser uma ameaça à ordem social, antes mesmo de cometerem um crime. Em uma passagem da História da loucura na idade clássica, Foucault assinala que o tema da loucura como sensibilidade social surgiu na Europa "aproximando-se do crime, da desordem, do escândalo, ele pode ser julgado, como estes, pelas formas mais espontâneas e mais primitivas dessa sensibilidade" (2005, p. 143), o que não foi diferente no Brasil.

O Código Penal de 1940 sofreu algumas alterações pela Lei de Execuções Penais de 1984, inclusive, no que dizia respeito às medidas de segurança. Entretanto, os princípios gerais de definição e aplicação da não punição aos crimes cometidos por loucos continuam sendo aqueles definidos em 1940 (PERES; NERY FILHO, 2002). Isso significa que a periculosidade, aquilo que determina a duração das medidas de segurança para todos os casos, é ainda hoje o dispositivo capaz de manter a restrição de liberdade dos loucos criminosos no Brasil. Enquanto o Novo Código Penal permitiu uma espécie de deslocamento da penalidade ao crime para a penalidade ao criminoso, com a adoção da doutrina da "defesa social" (BARRETO, 2003), no caso dos loucos, esse deslocamento se deu em outro sentido, já que não havia antes a figura do louco delinquente passível de ter seu crime responsabilizado. $\mathrm{O}$ Código Penal de 1940 inaugurou a não punição, o controle da loucura, com a invenção das categorias da periculosidade e da responsabilidade penal.

O surgimento da periculosidade no Código Penal de 1940 tem ainda uma consequência relevante para o futuro do indivíduo em medida de segurança. É que a volta ao passado do louco por um perito psiquiatra, para estabelecer a relação entre a loucura e o crime, não visa apenas revelar as motivações do crime, mas explicar o crime em si. Essa volta ao passado do louco tem uma diferença essencial em relação ao movimento dos juízes, que vão ao passado do criminoso para explicar a delinquência. A psiquiatria vai ao passado para demonstrar que, nas pequenas discrepâncias, nos surtos cotidianos, nas anormalidades mentais presentes em seu histórico, o louco anuncia a semelhança com o crime que cometeu em função de seu estado mental (FOUCAULT, 2001). Assim, o crime poderá ser considerado inteligível pelos juízes se, nos fragmentos de loucura anteriores evidenciados pela psiquiatria, o louco apresentar alguma incoerência em seu comportamento. E, então, o exame psiquiátrico reconstitui o histórico da insanidade do louco para encaixá-la na cena do crime (FOUCAULT, 2001).

O psiquiatra não analisa o louco para determinar a responsabilidade jurídica pelo ato criminoso - papel este dos juízes. Mas constata se existem anomalias mentais transpostas ao 
comportamento do louco para que, assim, possam ser relacionadas com o crime investigado. Para não assumir o papel dos juízes de apontar a responsabilidade penal, o elemento que o psiquiatra oferece para o julgamento são as condutas irregulares explicadas pela doença e deficiência mental, e é sobre elas que a medida de segurança para tratamento obrigatório irá atuar. Só assim o crime cometido pelo louco pode ser inimputável, e o louco ser passível de tratamento e correção. Ao oferecer à justiça o histórico de loucura do criminoso, isto é, o quanto seu comportamento anormal pode elucidar o crime cometido, a psiquiatria fornece algo mais que as motivações para a prática do crime: disponibiliza a periculosidade como sintoma da loucura, o que não necessariamente tem relação direta com o crime cometido, mas pode oferecer indícios de qualquer comportamento perigoso.

Como a duração da medida de segurança depende da cessação da periculosidade, a relação entre a psiquiatria e o direito no Código Penal de 1940 criou uma situação original: punição a um elemento não previsto no código porque está localizado, sobretudo, no futuro. Primeiro, porque a punição não diz respeito ao crime, nem busca no passado do criminoso a motivação do ato. A responsabilidade penal sobre a qual o controle da periculosidade ocorre diz respeito ao histórico de insanidade do louco. Em segundo lugar, a periculosidade não vai explicar apenas o crime em si, mas será desvendada, a partir do diagnóstico de loucura, da capacidade do louco de, sendo perigoso, praticar qualquer crime. Ou seja, a restrição de liberdade não é o requisito para o tratamento obrigatório ou a expiação do crime julgado, mas um efeito de defesa da sociedade voltado para o futuro e para a probabilidade de o louco voltar a cometer crime.

O conceito da periculosidade, que fez erguer uma estrutura de proteção à sociedade contra as ameaças que o louco pode trazer para todos, estabelece uma ligação direta entre o tema da loucura e o da segurança pública. Ainda hoje, qualquer tentativa de buscar respostas por meio de políticas públicas para proteção de direitos aos indivíduos em sofrimento mental que cometem crimes deverá dialogar com o instituto da periculosidade. Mesmo quando a proteção de necessidades básicas por meio da assistência social e de políticas de assistência em saúde mental nos últimos anos parece oferecer novas possibilidades, ainda é desafiante o fato de a temática dos indivíduos em sofrimento mental que cometem crimes permanecer na alçada quase exclusiva da segurança pública. Nesse sentido, a relação entre as medidas de segurança de indivíduos em fase de desinternação e o papel das famílias como entes responsáveis por lhes oferecer proteção perpassa dialeticamente por essa problemática da defesa da sociedade. 
A utilização da doutrina da defesa social em substituição à do livre-arbítrio para justificar o afastamento do louco que comete crimes se deu porque tanto juristas quanto psiquiatras denunciavam que os crimes mais violentos eram justamente aqueles cometidos por inimputáveis que permaneceriam em liberdade (ALMEIDA, 2005; CARRARA, 1998). No entanto, é fácil perceber que o que a psiquiatria passou a oferecer à prática judiciária como explicação para esses crimes não foi somente a possibilidade de ir ao histórico do louco perigoso que comete os crimes mais atormentadores, mas a de julgar as discrepâncias, as anormalidades, os comportamentos bizarros transformados em indícios colados ao histórico do indivíduo louco, que se torna, então, perigoso. O direito penal passa a ter como objeto de julgamento não mais o crime, mas o indivíduo perigoso (FOUCAULT, 2010b). Não mais o louco, porque ele é inimputável. Não mais sequer aquilo que o sujeito praticou. Para Foucault (2010b), uma consequência surpreendente da adoção da periculosidade pelo direito penal é que o direito passa a atuar sobre aquilo que o sujeito é em razão de sua doença ou deficiência mental: sua periculosidade, seu risco de cometer nova infração.

O crime, na virada do século XIX para o XX, tornou-se uma aposta importante para a psiquiatria se estabelecer como campo do conhecimento no Brasil. E essa aposta, o controle da loucura no caso de crimes, serviu positiva ou produtivamente para a criação de um novo saber dentro da loucura. Até 1940, os juízes poderiam ou não utilizar-se de uma perícia médica para auxiliar em decisões permeadas por complexidades que escapavam ao seu julgamento. Mas, a partir do Código Penal de 1940, a possibilidade da perícia médica deu lugar à compulsoriedade da perícia psiquiátrica nos casos de insanidade mental (ALMEIDA, 2005; CARRARA, 2010). Se a psiquiatria tornou-se tão importante a partir das primeiras décadas do século $\mathrm{XX}$, não foi somente porque ela aplicava uma nova racionalidade médica às doenças da mente. Foi também porque funcionava como uma forma de higiene pública (FOUCAULT, 2010a). E são inúmeros os achados de pesquisa no Brasil que confirmam tal empreitada (CARRARA, 2010; COSTA, 1979; CUNHA, 1986; MACHADO et al., 1978, PORTOCARRERO, 2002).

A psiquiatria no Brasil, nas primeiras décadas do século passado, conseguiu autonomia e se revestiu de prestígio e autoridade no caso da loucura e dos crimes cometidos pelo fato de ter se inscrito no âmbito de uma medicina concebida como reação aos perigos inerentes ao corpo social. Para a sociedade, o controle da loucura criminosa inventada pela medida de segurança servia como uma engenharia de não punição que apostava na transformação dos indivíduos perigosos, em seu tratamento. Controlar o louco que comete 
crimes com o tratamento obrigatório em restrição de liberdade tornou-se, entre as novas técnicas de controle e dos indivíduos, um conjunto de procedimentos orquestrados para modificar os infratores (FOUCAULT, 2010a). Passou a ser a humanização do presídio via tratamento, a racionalização da punição via vigilância constante, com isolamento parcial ou total a depender do tipo de loucura.

O resultado dessa racionalidade é que o controle da periculosidade passa a agir não mais sobre o crime cometido pelo louco, mas sobre o próprio criminoso: ou seja, sobre aquilo que o torna criminoso, seus motivos, aquilo que o move, seus traços patológicos e seus instintos (FOUCAULT, 2010a). Ao mesmo tempo em que reivindica o direito de se proteger, a sociedade oferece como contrapartida ao louco a justificativa da transformação dele e do perigo como sintoma de sua doença. Os crimes sem motivo, os crimes dos inimputáveis, sempre foram grandes desafios para o aparelho judiciário. Ao resolver o problema de ligação psicológica entre o louco e o crime sem razão, a mecânica punitiva de controle da periculosidade ganha melhores condições de se firmar na sociedade brasileira. Pois a psiquiatria passa a auxiliar o direito penal não somente para avaliar as motivações do sujeito, como acontece nos crimes sem razão, mas também para oferecer a racionalidade do ato, o conjunto das relações que ligam o ato aos interesses, mesmo que desrazoados, aos cálculos, às inclinações incontroláveis do sujeito, aos comportamentos decorrentes da loucura.

O modo como o conceito de periculosidade foi adotado no direito penal brasileiro trouxe duas consequências para a relação entre os indivíduos em medida de segurança e suas famílias. Em primeiro lugar, no tocante ao período considerado no direito penal como de desinternação condicional para esses indivíduos, os peritos médicos têm, cada vez mais, levado em consideração a relação entre o paciente e suas famílias para decretar a desinternação (MECLER, 2010). Dada a ausência de políticas de saúde mental e de assistência social específicas para essa população, a atribuição de cuidado e responsabilidade pelo indivíduo em medida de segurança tem sido transferida às famílias. Em segundo lugar, nem sempre a relação entre os indivíduos e suas famílias permite essa passagem automática da internação em ECTP para a liberdade condicional, tendo a família como agente responsável por garantir assistência e cuidado a esses pacientes para que, inclusive, haja a continuação do tratamento.

A partir dos anos 1940, deparamo-nos com várias características que tornam emblemático o saber dos governos no Brasil em sua resposta aos indivíduos com transtornos mentais que cometem crimes. O país experimenta seus primeiros anos de idas e vindas no 
processo de construção de um Estado-providência (BOSI, 1996). No entanto, esse Estadoprovidência vai dizer respeito essencialmente à classe trabalhadora, que passa a ter um conjunto de proteções e garantias ligadas ao mundo do trabalho, ao ponto de a cidadania peculiar no Brasil poder ser classificada, até o final dos anos 1970, como cidadania regulada, nos termos de Wanderley Guilherme dos Santos (1979). Nesse sentido, o Estado-providência ou Estado social brasileiro tinha um alcance bastante limitado em suas prerrogativas da garantia de direitos sociais. Aos indivíduos em medida de segurança, o Estado apenas oferece um dispositivo inédito que oscila entre tecnologia punitiva e assistencial por meio do tratamento psiquiátrico obrigatório nos manicômios judiciários.

Por último, o papel de provisão social e material para cobrir as privações decorrentes dos acasos da existência continua a cargo das famílias ou de iniciativas espontâneas da sociedade por meio da caridade e filantropia. O processo de modernização, burocratização e centralização do Estado, um dos anseios da população e de Getúlio Vargas a partir dos anos 1930, enfrentará constantes desafios no amadurecimento da administração pública (BOSI, 1996). Nesse sentido, a constituição de um saber específico que sustentaria o poder de governo no Brasil em tempos modernos ainda encararia entraves. Segundo Foucault (2008), para ocorrer a constituição do poder de governo, o poder familiar precisa ser destravado, ultrapassado, superado. É preciso destituir das famílias a força capaz de organizar a economia dos indivíduos e oferecer a eles o que é necessário a sua sobrevivência. O processo pelo qual o Estado passa a ser o ente responsável pela economia da família e da busca incessante pelo atendimento progressivo às suas necessidades não se deu de forma automática e natural no mundo nem no Brasil.

A obra Segurança, território, população faz parte do conjunto de aulas ministradas por Foucault no Collège de France em 1978 (FOUCAULT, 2008). O objetivo principal do livro foi o de apresentar uma das últimas fases dos trabalhos do autor, a denominada sociedade de segurança ou biopolítica. Nessa fase, Foucault atribui grande importância ao "poder sobre a vida", à ação sobre o homem como espécie ou população e não mais como corpo, corpo sujeitado, corpo docilizado, como foi nos estudos anteriores, em que ele caracterizou a chamada sociedade disciplinar. Em Vigiar e punir, por exemplo, as disciplinas são os métodos que permitem o controle minucioso das operações do corpo, que realizam a sujeição constante de suas forças e lhes impõem uma relação de docilidade/utilidade. Agora, Foucault busca mostrar em que consistem algumas tecnologias de segurança, entendendo que 
cada uma delas resulta, em boa parte, da reativação e da transformação de técnicas jurídicolegais e disciplinares.

Para isso, Segurança, território, população tem uma premissa fundamental: a de que o poder não se funda em si mesmo e não se dá a partir de si mesmo. O poder não é uma substância, um fluido, algo que decorreria de outro algo. Mas é importante admitir que ele é um conjunto de mecanismos e de procedimentos que tem como função manter justamente o poder. Nessa obra, portanto, Foucault parte da ideia de que segurança é uma maneira de acrescentar, de fazer funcionar, além dos mecanismos propriamente de segurança, as velhas estruturas da lei e da disciplina. Nesse sentido, a análise dessas relações de poder pode se abrir para algo como a análise global de uma sociedade. Foucault busca primordialmente caracterizar a governamentalidade, tema cuja aula principal já havia sido publicada no Brasil na coletânea Microfísica do poder.

$\mathrm{O}$ que vem a ser governamentalidade? Na obra, em alguns momentos aparece apenas com o sentido de "a arte de governar" e, em outros momentos, há uma definição mais específica:

o conjunto constituído pelas instituições, os procedimentos, análises e reflexões, os cálculos e as táticas que permitem exercer uma forma bem específica, embora muito complexa, de poder que tem por alvo principal a população, por principal forma de saber a economia política e por instrumento técnico essencial os dispositivos de segurança (FOUCAULT, 2008, p. 25).

A principal hipótese de Foucault, então, é a de que o Estado foi gradativamente governamentalizado, conduzido à preeminência de um tipo de poder que podemos chamar de governo (ou governamento) e que se impõe sobre todos os outros tipos de poder, como o de soberania ou o de disciplina.

Foucault (2008) faz uma distinção entre três grandes tipos de poder: o poder soberano, o disciplinar e o biopoder. Mas eles não são dissociados. Não há algo como a era do legal, a era do disciplinar e a era da segurança. Foucault ressalta que o que muda é apenas o "dominante" em cada contexto histórico. Ou seja, o que muda é o sistema de correlação entre os mecanismos jurídico-legais, os mecanismos disciplinares e os mecanismos de segurança. De forma esquemática, os dispositivos de segurança, objeto do livro do autor, podem ser caracterizados por seus espaços de segurança, por seu tratamento do aleatório e por sua forma específica de normalização. Desse modo, correlacionam-se a técnica de segurança e a população através de um meio ou instrumento. O meio passa a ser compreendido como um 
campo de intervenção em que se procura atingir uma população, em vez de indivíduos como sujeitos de direito ou corpos como organismos objeto de ação da disciplina.

$\mathrm{Na}$ sociedade de soberania, o poder do soberano é exercido sobre um território. $\mathrm{Na}$ sociedade disciplinar, o poder das instituições é exercido sobre os espaços disciplinares. Já na sociedade biopolítica ou de segurança, o poder acontece em uma relação poder-espaço, ou seja, é exercido no controle dos fluxos, da circulação, não do homem como indivíduo ou corpo, mas do homem como espécie, tendo o objetivo de controle da população. Desse modo, "população" tem uma importância central para Foucault na medida em que se estabelece a relação com o poder, com o biopoder. Segundo o autor, a questão das populações emergiu nos séculos XVI e XVII, principalmente por meio da economia e da estatística, em uma busca estatal pelo controle das populações que diz respeito à reprodução, natalidade, mortalidade e circulação. Com a emergência da questão da população, há uma série de dispositivos de segurança criados para garantir padrões de reprodução e algum direcionamento na circulação da população.

Foucault localiza que, a partir do século XVII, ocorre o processo de governamentalização do Estado. Há diversas lutas e dimensões forjadas por táticas de governo para permitir o que deve estar no âmbito do Estado. Dessas lutas, há três fases: o Estado de Justiça, nascido numa territorialidade feudal que diz respeito a uma sociedade da lei, estruturada por jogos de compromissos, acordos e litígios; o Estado Administrativo, nascido numa territorialidade fronteiriça, nos séculos XV a XVI, correspondendo a uma sociedade de regulamentos e disciplinas; e o Estado de Governo, que não é definido apenas por uma territorialidade ocupada, mas por uma massa da população. Essas três fases são os fundamentos do que Foucault conceitua como governamentalidade. É um percurso que se inicia nos princípios do pastoreio cristão, passa por transformações até atingir um instrumento específico, a polícia, para chegar a configurações contemporâneas com técnicas diplomáticomilitares.

É apresentada por Foucault uma constituição dos saberes e das práticas da polícia. Ele localiza a polícia, surgida no século XVII, como um aparelho destinado a fazer as forças do Estado crescerem, mantendo ao mesmo tempo uma boa ordem interna. Valores como a bondade e a conservação do modo de viver e de uma estrutura de comodidade estão presentes na constituição desse mecanismo utilizado para a segurança das populações. Ao polícia nasce com o objetivo não só de garantir a existência da sociedade civil, mas de bem assegurá-la. $\mathrm{Ou}$ seja, para Foucault, comércio, cidade, regulamentação, disciplina são os elementos mais 
característicos da prática da polícia no século XVII. Em outras palavras, o Estado tem a seu encargo uma sociedade civil, e é a gestão dessa sociedade que ele deve assegurar. Há um projeto da polícia direcionado a uma correlação com a razão do Estado.

O objetivo fundamental da governamentalidade é de utilizar dos mecanismos de segurança ou da intervenção do Estado para garantir a segurança dos fenômenos naturais que são os processos econômicos ou os processos intrínsecos à população. De um lado, há uma série de mecanismos que são do domínio da economia, do domínio da gestão da população, e que têm por função fazer crescer as forças do Estado; de outro lado, existe certo aparelho e certo número de instrumentos que vão garantir que a desordem, as irregularidades, os ilegalismos, as deliquências sejam impedidos ou reprimidos. A eliminação da desordem passa a ser a função da polícia. Assim, a noção inicial ou a função inicial da polícia do século XVII se altera profundamente, se marginaliza e adquire o sentido puramente negativo que conhecemos atualmente. Se, no século, XVII, a polícia era um instrumento que fazia crescer as forças do Estado, agora, terá de referir-se a um domínio de naturalidade que é a economia. Terá de administrar populações, terá de organizar um sistema jurídico de respeito às liberdades.

É em razão desse poder/saber que a governamentalidade busca dar conta dos princípios de atuação dos governos. Governamentalidade refere-se então ao conjunto de instituições, procedimentos, cálculos e táticas que "permitem exercer uma forma bastante específica e complexa de poder, que tem por alvo a população, por forma principal de saber a economia política e por instrumentos técnicos essenciais os dispositivos de segurança", (FOUCAULT, 2008, p. 50), que dão conta da força motriz que origina as ações dos governos. Há, em certo sentido, uma tendência que em todo o Ocidente conduziu incessantemente, durante muito tempo, à preeminência desse tipo de poder, que se pode chamar de governo, sobre todos os outros — de soberania, de disciplina etc — e ao desenvolvimento de uma série de aparelhos de governo e de um conjunto de saberes. As medidas de segurança, assim como as polícias, constituem um dispositivo desses aparelhos que estruturam o poder dos governos, mas não só elas. Por outro lado, as políticas de assistência e de saúde mental também representam aparelhos específicos que têm por alvo as populações e por finalidade uma forma de produção de poder dos governos sobre os indivíduos em seu conjunto, visando à garantia do atendimento de provisões ligadas às privações e às demandas por assistência em saúde.

É sobre a investigação dessa forma específica de governo, sobre o modo como o Estado brasileiro se governamentalizou no que diz respeito aos indivíduos loucos que 
cometem crimes, que esta tese se estrutura. De forma esquemática, a presença do familismo nas políticas sociais pode demonstrar que o Estado brasileiro não assumiu, ou assumiu de forma incompleta e peculiar, a governamentalidade em suas ações. Nesta tese, a volta por trás do Estado ou ao fundo dele, no sentido de organizar as características que determinam seus efeitos de governamentalidade, testará, com a hipótese do familismo, os entraves e destravamentos do processo de desfamiliarização das políticas sociais no Brasil.

Por sua vez, o familismo é um conceito de Gøsta Esping-Andersen (2000) para designar a característica das políticas econômicas e sociais dos Estados pós-Segunda Guerra Mundial que destinam às famílias grande parte da responsabilidade sobre a provisão de bens e serviços ligados ao bem-estar social; bens e serviços estes que deveriam ser promovidos pelas políticas públicas e sociais sob a responsabilidade dos Estados. O grau de desfamiliarização das provisões oferecidas pelas políticas socais é análogo ao conceito de desmercadorização, também de Esping-Andersen, utilizado para designar aqueles Estados que conseguiram assumir grande parte da responsabilidade pelas provisões de bem-estar social aos cidadãos, diminuindo a atuação dos mercados nessa função (ESPING-ANDERSEN, 2000). Os regimes familistas de bem-estar social acabam por transferir às famílias o papel de cobrir os riscos sociais para enfrentar as situações de insegurança da população (CASTEL, 2005), o que pode implicar a incapacidade de reduzir desigualdades e injustiças sociais históricas de determinada sociedade.

Os regimes familistas tendem a florescer em sociedades com doutrina católica arraigada (SUNKEL, 2006). A centralidade da família em uma sociedade tende a ser favorecida por doutrinas religiosas, mas não somente por isso (ESPING-ANDERSEN, 2000; SUNKEL, 2006). O modo como a família varia em importância entre as instituições de determinado arranjo social limita a interferência pública por meio de políticas sociais para combater privações sociais (CASTEL, 2005). Mas é preciso analisar os países caso a caso para determinar as causas e consequências do familismo (ESPING-ANDERSEN, 2000). Para Esping-Andersen, é comum os textos que analisam os Estados de bem-estar social suporem que as responsabilidades assistenciais das famílias foram efetivamente desfeitas pelo advento dos Estados de bem-estar social modernos, surgidos a partir da Segunda Guerra Mundial (ESPING-ANDERSEN, 2000). Entretanto, as provisões, principalmente aquelas de caráter assistencial que ocorrem no interior dos domicílios e são destinadas aos indivíduos, continuam sendo oferecidas em conjunto pelas famílias e, em menor grau, pela atuação do Estado por meio de políticas sociais. 
Grande parte das cargas assistenciais demandadas pelos cidadãos continua atendida pelas famílias. Poucos países conseguiram alcançar significativamente uma desfamiliarização na provisão de bem-estar social aos indivíduos. Os primeiros países que ampliaram os bens e serviços destinados às famílias — de forma particular a atenção à infância, às pessoas com deficiência e aos idosos no próprio domicílio - foram Dinamarca e Suécia, nos anos 1960, e Noruega, Finlândia, Bélgica e França, nos anos 1970 (ESPING-ANDERSEN, 2000; PRINZ, 2003; SPOSATI, 2004). Por outro lado, países como Alemanha, Itália e Espanha destinam importantes ações de proteção à infância por meio de ações de assistência e educação para crianças entre 3 e 6 anos, descarregando a responsabilidade de cuidado das famílias (ESPING-ANDERSEN, 2000; PRINZ, 2003). As principais ações da maioria dos países europeus que criaram importantes políticas públicas voltadas ao bem-estar social da população a partir dos anos 1950 - caracterizando a chamada Era de Ouro do Welfare-State europeu - ficaram restritas às transferências de renda para combate à pobreza, às proteções à infância e à velhice e a melhorias para qualificação da mão de obra para ingresso no mercado de trabalho. A assistência social voltada aos indivíduos no interior das famílias continua uma situação sem atenção por parte das políticas públicas na vasta maioria dos países.

Além da assistência social, outra política pública que deveria acolher as pessoas que cumprem medida de segurança é a de saúde mental, inaugurada com a Lei da Reforma Psiquiátrica, a Lei 10.216, de 2001. Essa lei cria condições jurídicas e de aparato normativo às políticas públicas de assistência em saúde capazes de atender às particularidades das pessoas em sofrimento mental. Ela tem sido cada vez mais apontada como uma possibilidade para orientar a aplicação das medidas de segurança como alternativa à internação em HCTPs (BARROS-BRISSET, 2010; BRASIL, 2010b; SILVA, 2010).

De acordo com o paradigma de atenção psicossocial expresso na Lei 10.216, a atenção psiquiátrica deve ser estruturada de forma a oferecer assistência integral à pessoa portadora de transtornos mentais, incluindo serviços médicos, de assistência social, psicológicos, ocupacionais e de lazer em meio aberto (BARROS-BRISSET, 2010). Por meio de serviços de assistência psicossocial comunitários próximos às residências dos pacientes, da instalação de equipamentos públicos para moradia dos pacientes, denominadas residências terapêuticas, e das políticas de transferência de renda com o objetivo de promover a inclusão social dos pacientes com transtorno mental, a Lei 10.216 criou condições efetivas para garantia de cidadania da população em sofrimento mental em um paradigma não asilar. Esse novo modelo, quando comparado ao tratamento que também é finalidade na aplicação das medidas 
de segurança, lança perguntas sobre o quanto a execução penal dessas medidas respeita as garantias constitucionais de individualização da pena e proibição de pena perpétua, enfim, os direitos fundamentais das pessoas em sofrimento mental no país, tendo por marco a Reforma Psiquiátrica.

Em 2004, por influência da Lei 10.216, de 2001, o Conselho Nacional de Política Criminal e Penitenciária (CNPCP) estabeleceu, por meio da Resolução 5, que as medidas de segurança passariam a ser executadas em HCTPs, tendo a lei antimanicomial como diretriz orientadora (BRASIL, 2004a). Segundo a resolução, "a atenção prestada aos pacientes inimputáveis deverá seguir um programa individualizado de tratamento, concebido por equipe multidisciplinar que contemple ações referentes às áreas de trabalho, moradia e educação e seja voltado para a reintegração sócio-familiar” (BRASIL, 2004a, p. 2). Além disso, naqueles estados onde não houvesse HCTPs, os pacientes deveriam ser tratados na rede de serviços do SUS. Em julho de 2010, o mesmo CNPCP publicou a Resolução 4, ampliando a incorporação das diretrizes da Lei 10.216 para orientar a aplicação das medidas de segurança em todo o país (BRASIL, 2010b). Segundo essa resolução, o cumprimento das medidas de segurança deve ocorrer "de modo antimanicomial, em serviços substitutivos em meio aberto" (BRASIL, 2010b, p. 2). No entanto, o caráter diretivo das resoluções do CNPCP não é capaz de superar automaticamente o modelo manicomial de aplicação das medidas de segurança para seguir os princípios estabelecidos pela Lei 10.216.

Em que medida o familismo está presente em tais ações e quais os impactos do familismo no processo de governamentalização das ações do Estado brasileiro? É a esse questionamento aparentemente generalista demais que a hipótese do familismo pode acrescentar camadas explicativas para o processo de investigação a respeito do que está por trás do surgimento dos esquecidos dos manicômios judiciários. De 1940 a 2011, há poucas novidades no que diz respeito ao funcionamento das medidas de segurança. No entanto, há uma série de novos arranjos, novas experimentações, dispositivos e táticas nas políticas sociais que podem auxiliar no momento da desinternação dos indivíduos em medida de segurança. É a esse momento externo aos manicômios judiciários, mas ligado a ele, que se destinarão esforços nesta tese para uma análise da constituição de nossas políticas públicas. A hipótese do familismo pode ser considerada geral demais para os objetivos aqui propostos, mas corresponde a uma investigação dos princípios e das forças fulcrais às políticas sociais que podem revelar muito da história da governamentalização do Estado brasileiro. 


\subsection{Estado social no Brasil: a cidadania inconclusa e o papel do Estado no bem-estar social a partir de 1988}

Houve uma grande expectativa a respeito da Constituição Federal de 1988, seja pelo seu ineditismo no tocante aos elementos da cidadania a ser garantida a partir dali, seja por sua promulgação ocorrer após um longo período de restrição democrática que o país atravessou desde 1964, com o Golpe Militar e a interrupção de muitos direitos individuais e políticos. A assistência social foi a última das políticas componentes da seguridade social a ser regulamentada, em 1993 — cinco anos após a promulgação da Constituição Federal de 1988 (BOSCHETTI, 2006). Esse atraso para regulamentar a assistência social pode ser reflexo da resistência em assimilá-la como direito social. Destacar o modo como se deu essa recepção à assistência como direito de seguridade ganha relevância, uma vez que havia expectativas em torno da seguridade social em oferecer respostas às históricas situações de pobreza e desigualdade social no país (BOSCHETTI, 2006; BUCCI, 2006). O longo período de ditadura militar e o quadro socioeconômico de pobreza e desigualdade social fizeram com que a Constituição de 1988 não somente comportasse objetivos relacionados à reafirmação democrática (BUCCI, 2006), mas estabelecesse diretrizes para a composição de uma estrutura de políticas públicas para a promoção do bem-estar social à população - marcadamente pobre e com renda historicamente distribuída de forma desigual entre seus estratos (DRAIBE; AURELIANO, 1989; IPEA, 2006; TORRES, 2008).

Para Maria P. Dallari Bucci (2006), em sociedades com menor tradição de garantia de liberdades individuais e menos desenvolvidas do ponto de vista das condições socioeconômicas da população, como no Brasil, a afirmação de direitos sociais como aconteceu na Constituição Federal de 1988 só faz sentido se estiver associada a um conjunto de garantias equivalentes ao que permitiu que os direitos individuais, civis e políticos se transformassem em referencial jurídico do Estado de direito. Essas características aumentam a pressão e a responsabilidade pela materialização dos preceitos constitucionais, no sentido de que os direitos sociais funcionam como instrumentos de proteção contra as privações sociais e, ao mesmo, como meios para garantir igualdade e liberdade a todas as pessoas (CASTEL, 2005; HERRERA, 2008). É nesse sentido que os objetivos fundamentais do Estado democrático brasileiro estabelecidos na Carta de 1988 dizem respeito não somente ao restabelecimento dos valores democráticos, mas também às aspirações de criação de condições para superação da profunda desigualdade socioeconômica do país (BUCCI, 2006). 
A partir dos anos 2000, uma abrangente estrutura de políticas públicas e sociais passou a orientar a rede de proteção social em todo o território nacional, com o objetivo de garantir às pessoas o acesso a bens sociais essenciais que suprissem as necessidades humanas básicas (IPEA, 2006; MENDONÇA, 2008; VAITSMAN; ANDRADE; FARIAS, 2009). Antes mesmo da formulação da Política Nacional de Assistência Social (PNAS), aprovada em 2004, responsável por organizar a disponibilização das políticas, dos programas e dos benefícios da assistência social, desde 1998, com o respaldo da Lei 9.533, criou-se a possibilidade de o Estado brasileiro conceder apoio financeiro aos municípios que instituíssem programas de garantia de renda mínima associados a ações socioeducativas para crianças e adolescentes (BRASIL, 1997).

Desse modo, no final da década de 1990, por meio de políticas de transferência de renda e de combate à pobreza e a situações de violação de direitos de crianças e adolescentes, começavam a se esboçar algumas das diretrizes que orientariam as medidas de proteção social expressas na PNAS em 2004. Em estudo publicado em 2004, Maria Ozanira Silva, Maria Carmelita Yazbek e Geraldo di Giovanni realizaram um levantamento até aquele ano e descobriram que existiam 45 iniciativas de políticas de transferência de renda espalhadas no território nacional sob garantia de diversas esferas de governo. Políticas de transferência de renda articuladas a outras situações de privação que não somente à pobreza passaram a dar o tom do sistema de proteção social brasileiro a partir dos anos 2000 (IPEA, 2006).

A PNAS foi estruturada em 2004 tendo como objetivos cinco tipos de segurança social: acolhida, renda, convivência, desenvolvimento de autonomia e sobrevivência a riscos circunstanciais (BRASIL, 2004). Nos últimos anos, o perfil de efetivação da assistência social ganhou novos contornos no país, seja pelo aumento do financiamento público para gastos específicos com a assistência, seja pelo aumento considerável do número de pessoas atendidas (IPEA, 2006; MENDONÇA, 2008; VAITSMAN; ANDRADE; FARIAS, 2009). A assistência passou a ser estruturada de modo a se articular com as políticas de segurança alimentar e nutricional, o sistema educacional e o combate à violação de direitos básicos de crianças e adolescentes (IPEA, 2006; VAITSMAN; ANDRADE; FARIAS, 2009). O sistema de proteção social brasileiro, que desde os anos 1930 vincula-se ao trabalho, sobretudo, como medidas securitárias garantidas aos trabalhadores do regime formal (BOSCHETTI, 2006; DRAIBE; AURELIANO, 1989; SANTOS, 1979), teve os objetivos e alcances ampliados nos últimos vinte anos, principalmente pelas diretrizes demarcadas na Constituição e pela execução da PNAS. 
Foi preciso o direito à assistência ser explicitado na legislação constitucional para que a mudança de compreensão ganhasse contornos objetivos por meio da estruturação de políticas públicas que materializariam o direito social. Apenas recentemente constatou-se o esforço da política de assistência para estabelecer uma rede de proteção social pública que resguardasse as pessoas de situações de privação resultantes da pobreza, desigualdade social e violação de direitos básicos (IPEA, 2006; SILVA; YAZBEK; DI GIOVANNI, 2004; VAITSMAN; ANDRADE; FARIAS, 2009). Desse modo, o direito à assistência social é efetivado por várias frentes, desde a proteção a violações de direito sofridas por crianças, adolescentes, mulheres, idosos e pessoas com deficiência e a articulação da assistência com outras políticas públicas até a disponibilidade de benefícios de transferência de renda com os objetivos de combater a pobreza e reduzir as desigualdades sociais.

A estruturação da política, a garantia e o aumento do financiamento nos últimos anos, bem como o alcance maior do público atendido, são alguns avanços verificados na história recente da assistência social como ação pública (IPEA, 2006; SOARES et al., 2006; VAITSMAN; ANDRADE; FARIAS, 2009). Entretanto, a pobreza extrema, a desigualdade social e as recorrentes violações de direitos fundamentais continuam a fazer parte de um contingente significativo da população que deveria ser coberto pela assistência social para a efetivação da cidadania e dos direitos humanos (IPEA, 2006). Não é plausível pressupor a assistência social como única política responsável por reverter esse cenário, tampouco tratá-la como uma das responsáveis por criar condições para valorizar a cidadania e garantir os direitos humanos a toda a população.

A assistência social é compreendida por Marcelo Leonardo Tavares (2008) como direito social prestacional e essencial devido ao seu estreito relacionamento com os fundamentos do Estado democrático de direito, especialmente, a dignidade da pessoa humana. A garantia da dignidade humana exige que a assistência social assuma um plano de prestações sociais que garantam um padrão mínimo de satisfação das necessidades básicas às pessoas impossibilitadas de manterem sua sobrevivência; padrão este abaixo do qual a uma pessoa não pode se localizar, pois a dignidade humana ficaria comprometida (TAVARES, 2008). Até a Constituição Federal de 1988, o sistema de proteção social brasileiro era ligado estritamente ao direito ao trabalho, por meio de benefícios previdenciários, e às políticas de saúde que exigiam contribuições prévias dos trabalhadores (SANTOS, 1979; BOSCHETTI, 2006). Além disso, a assistência social era composta por medidas esparsas e desarticuladas da responsabilidade do Estado, pois contavam apenas com a atuação de instituições religiosas e 
da sociedade civil por meio da filantropia, sendo o Estado mero auxiliar na elaboração do arcabouço legal e, parcialmente, no financiamento das ações (BOSCHETTI, 2006). A assistência percorreu um longo caminho para que, embasada em um texto constitucional, fosse compreendida como direito fundamental que a tornasse necessária de efetivação independente de outras garantias e objetivos sociais (LEIVAS, 2006; TAVARES, 2008; PULIDO, 2008; SARMENTO, 2008).

O cenário da assistência social a partir da última Constituição Federal tornou-se inovador não somente pela estruturação nos anos recentes de políticas públicas e sociais que criam condições para a materialização do direito social, mas também pelo modo como o acesso ao direito à assistência passou a ser reivindicado pelas pessoas a quem ela seria destinada e como instrumento de fortalecimento da democracia. A ideia democrática nasceu na Grécia Antiga com a aspiração de que o tipo de governo para tomar as decisões políticas de determinada sociedade seria aquele em que o poder seria exercido do povo para o povo. $\mathrm{O}$ regime democrático simbolizaria uma aspiração dos desejos humanos em torno dos valores da igualdade, liberdade e justiça garantidos a todos os cidadãos (GOYARD-FABRE, 2003). Mas, à medida que as sociedades cresceram e as relações sociais se tornaram complexas, ficaram latentes os desafios ao ideal democrático grego de que todos os cidadãos teriam igual poder de influência direta sobre os rumos das decisões coletivas. E, hoje, a existência de governos democráticos na maioria das sociedades contemporâneas poderia sugerir o triunfo inconteste dessa escolha sobre as demais formas de governo.

Entre o consenso moderno em torno dos ideais democráticos e as condições que permitem que a quase totalidade das sociedades contemporâneas experimente algum tipo de regime democrático, existe uma demonstração não menos importante a ser feita a respeito dos dilemas das democracias. Isto é, com abordagens distintas, mas densas, Platão e Aristóteles foram os primeiros a apontar as fragilidades e até mesmo os desafios que o regime democrático poderia representar para as aspirações humanas e a necessidade de solucionar seus conflitos políticos (GOYARD-FABRE, 2003). E esses desafios estão presentes em configurações democráticas contemporâneas. Acredita-se que o regime democrático endossaria o individualismo, podendo também criar barreiras à concretização da ideia do ser humano como sujeito livre, uma vez que a necessidade do igual respeito e consideração por todos aniquilaria a possibilidade de liberdade para muitos (GOYARD-FABRE, 2003). Ou seja, paralelamente ao fato de que os governos democráticos se expandiram de forma 
vigorosa, sobretudo, a partir de meados do século XX, algumas premissas democráticas passaram a ser apresentadas com cautela.

Nas democracias contemporâneas, o princípio clássico de que o povo deve governar para o povo foi substituído pelo ideal de que a fonte do poder político, a fonte da governamentalidade, nos termos de Foucault, passe a ser constituída pela vontade do povo (GOYARD-FABRE, 2003). Essa mudança é significativa e acompanhou as transformações estruturais das sociedades, bem como o crescimento das cidades e do próprio papel dos Estados constitucionais. No entanto, a força da vontade popular como capaz de interferir no rumo das decisões coletivas possui distintas manifestações por uma intricada teia de instituições e relações sociais que devem, entre outros objetivos, abarcar a vontade popular de forma indireta por representação ou por meio da participação direta nas decisões políticas. Os ideais que sustentam a democracia têm de ser construídos moral, jurídica e politicamente por meio da fragmentação do poder público e da distribuição das responsabilidades e capacidades governamentais a órgãos distintos, para que haja o controle mútuo e recíproco dos Poderes Legislativo, Executivo e Judiciário (KOLM, 2000). Essa distribuição das atribuições dos poderes, associada à afirmação dos direitos fundamentais de cada indivíduo submetido às normas constitucionais da sociedade, implica a materialização dos princípios do direito inegociável dos cidadãos à igual liberdade e dignidade humana — hoje, objetivos principais dos Estados democráticos de direito (HERRERA, 2008).

A democracia tanto como regime político quanto como ideal acerca da realização das potencialidades humanas favorece, de modo geral, as condições que permitem às sociedades solucionar seus conflitos éticos e políticos (GOYARD-FABRE, 2003). Entre eles, a regulamentação dos conflitos de interesses que emergem não só da convivência coletiva, das propostas de satisfação das necessidades humanas básicas, dos interesses pessoais e das oportunidades sociais como também da discussão sobre como deve ser promovido o acesso aos recursos materiais finitos pelos indivíduos em uma sociedade produtiva (FLEISCHACKER, 2006; GOYARD-FABRE, 2003). Apesar de a justiça ser o princípio ou a virtude moral surgidos ainda na Grécia Antiga como responsáveis por oferecer elementos para a proposição da solução para tais conflitos (DWORKIN, 2005; KOLM, 2000), a ideia de que a estrutura de distribuição de recursos materiais para a satisfação das necessidades humanas básicas deve ser uma questão de justiça é um conceito recente e assumiu contemporaneamente contornos singulares (FLEISCHACKER, 2006). De acordo com Samuel Fleischacker (2006), essa ideia pode ser percebida no longo processo histórico que acompanhou o desenvolvimento 
dos valores da democracia e da justiça distributiva, segundo os quais todas as pessoas têm o direito inegociável a uma parcela equitativa dos recursos materiais e bens sociais como satisfação das necessidades básicas (DWORKIN, 2005; GOYARD-FABRE, 2003).

O conceito de justiça distributiva pode ser atribuído a Aristóteles (2000), que sugeriu que uma maior distribuição de status político era pretendida como forma de igualar as condições de vida e promover justiça de modo geral nas sociedades (MAFFETTONE; VECA, 2005). Promover a igualdade de status político sem dúvida é fundamental para a proposta justa de qualquer estrutura distributiva de uma sociedade, mas o desenvolvimento do paradigma de justiça distributiva mostrou que igualar outras esferas da vida também passou a ser visto como reivindicação básica de justiça (FLEISCHACKER, 2006). Da proposta aristotélica até os dias atuais, o desenho de uma estrutura distributiva justa de bens materiais às pessoas passou a ser pretendido de forma a incorporar propostas mais específicas a fim de eliminar o máximo possível as carências materiais (FLEISCHACKER, 2006). As pessoas ganharam um direito fundado na justiça à proteção contra as privações materiais. Incorporar a eliminação da pobreza tornou-se o aspecto inovador na compreensão do paradigma moderno de justiça distributiva em comparação com a noção clássica (FLEISCHACKER, 2006). Pois em uma democracia, os ideais de liberdade, igualdade e autonomia individual não são possíveis de materialização sem a mitigação ou eliminação por completo da pobreza e das desigualdades socioeconômicas, que podem ter impactos significativos na redução das capacidades humanas (SEN, 2000).

O paradigma da justiça distributiva passou a oferecer diretrizes para a ação pública, possibilitando fornecer às pessoas o que lhes é devido. Mas sua importância está em que é possível estabelecer parâmetros para designar o modo a partir do qual a sociedade garante um padrão de justiça a todas as pessoas, partindo do equacionamento entre a finitude dos recursos e as necessidades humanas ilimitadas. Como os recursos são finitos, não é possível dividir tudo a todos de modo a igualar as posições, preferências e necessidades (PULIDO, 2008; SEN, 2001). É preciso estabelecer um ponto a partir do qual seja plausível extrair métodos para que a estrutura distributiva dos recursos opere a fim de atingir objetivos predeterminados (FLEISCHACKER, 2006; SEN, 2001). Na proposta aristotélica da distribuição da justiça distributiva, o mérito seria a característica relevante para considerar um indivíduo como merecedor de uma alteração na distribuição do status político (ARISTÓTELES, 2000; MAFFETTONE; VECA, 2005). É de pouco depois de meados do século XX a sugestão de 
que alguma distribuição de bens é preferível e devida a todos os seres humanos, como um princípio de justiça e de igual consideração (FLEISCHACKER, 2006).

Com a Constituição de 1988, tais características compuseram o sistema de seguridade social no Brasil (BOSCHETTI, 2006). Nesse sentido, os direitos sociais compreendidos como direitos fundamentais assumem duas características interessantes quando se analisa o fenômeno da governamentalidade no tocante às políticas públicas que buscam materializar direitos sociais. Em primeiro lugar, a sua finalidade voltada para a população tem o caráter de vinculação aos princípios democráticos, como justiça social, garantia dos direitos humanos e proteção da dignidade humana, ao buscar combater as desigualdades sociais. Em segundo lugar, a tarefa de provisão social nem sempre se dá de forma simples por meio de uma centralização automática do papel do Estado em tal atribuição. É comum comemorar os avanços das políticas de assistência social a partir de 2004 e dos serviços substitutivos de saúde mental a partir de 2001. Entretanto, tais avanços esbarram em limites que requerem análise. A limitação da cobertura, a persistência de algumas desigualdades sociais e as dificuldades em atuar nos elementos estruturais que rompem com o ciclo da reprodução das vulnerabilidades - tais como desafios em ter uma política de educação robusta, incremento de formação e qualificação para uma maior qualidade no mundo do trabalho, investimentos em tecnologias sustentáveis que agregam valor às cadeias produtivas — são exemplos que refletem na baixa capacidade das políticas sociais em promover incrementos a longo prazo nos padrões de bem-estar social.

Além disso, há uma série de situações e eventos que ainda carecem de cobertura das políticas de assistência social e dos serviços substitutivos de saúde mental (e não é apenas ao nível de cobertura), do ponto de vista da natureza e finalidade das ações que omitem situações específicas, como o caso aqui analisado dos indivíduos em medida de segurança. É importante a análise do nível de efetividade de tais ações para os indivíduos em medida de segurança, seja de forma geral, em todo o país, seja de forma local, em determinadas regiões de abrangência de um ECTP. No entanto, a investigação de por que ações da política de assistência social e de saúde mental não alcançam os indivíduos em medida de segurança não pode prescindir de uma análise da natureza, dos princípios e da configuração histórica de tais ações. O frisson de muitas das análises atuais em torno dos avanços da assistência social e da política de saúde mental que romperam, respectivamente, com o legado da caridade e do asilamento psiquiátrico pode apagar os determinantes dessas políticas sociais que explicam seu alcance limitado aos indivíduos em medida de segurança no presente (CAMPELLO; 
NERI, 2013; MENDONÇA, 2008; VAITSMAN; ANDRADE; FARIAS, 2009). O familismo pode revelar por que ações da assistência social e dos serviços substitutivos de saúde mental não alcançam os esquecidos dos manicômios judiciários, dado que representa, nas políticas sociais, um dos impedimentos à governamentalização das ações do Estado brasileiro. 


\section{PROCEDIMENTOS METODOLÓgICOS: ANÁLISE DE POLÍTICA PÚBLICA, GENEALOGIA E ESTUDO DE CASO}

O materialismo histórico é a corrente de pensamento que trata a produção da existência humana como resultante dos determinantes históricos e materiais (MARX, 2004). Os eventos não são fatos isolados, mas fatos singulares, dependentes da dialética da totalidade (COELHO, 2013). Nesse sentido, as políticas sociais são elementos imersos nas contradições inerentes a um Estado capitalista e dependem, para seu escopo, dos determinantes históricos e materiais da realidade a que se destinam. As políticas sociais têm como principal atribuição a concretização de direitos sociais para atender às necessidades que, no sistema capitalista, constituem a força desencadeadora da conquista da cidadania e das mudanças ao mesmo tempo em que contribuem para a manutenção do modo de produção capitalista (PEREIRA, 2014). Para Potyara Pereira (2014), as políticas sociais se impõem como uma ação pública complexa que não condiz com a ideia pragmática de mera provisão, ato governamental, receita técnica ou decisão tomada pelo Estado e alocada verticalmente na sociedade.

A apreensão da política social, nessa perspectiva, exige um esforço aprofundado de conhecimento dos seus movimentos, tendências e relações (FALEIROS, 1986; PEREIRA, 2014). Para tanto, a análise das problemáticas a respeito das respostas que o Estado lhes oferece tem de levar em consideração este ponto de partida: as políticas sociais, ao mesmo tempo em que desencadeiam mudanças para ampliação da cidadania dos sujeitos, são influenciadas pelas contradições inerentes à estruturação da sociedade capitalista. Nas palavras de Jaques Deleuze (2000), é a história que define as condições para a produção do sujeito, e este, ao se produzir, reproduz a história. Ou seja, “cada formação histórica vê e faz ver tudo o que pode em função das suas condições de visibilidades, assim como diz tudo o que pode em função das suas condições de enunciado" (DELEUZE, 2000, p. 87). O conteúdo de política social, desse modo, depende das forças materiais e históricas que definem suas bases de sustentação.

A partir disso, qual seria o método apropriado para analisar o surgimento, o desenvolvimento e a maturação de determinada política social, sendo capaz de captar as contradições que fazem parte do jogo de forças no interior de um Estado capitalista e na sua relação dialética com as demais forças e instituições presentes na sociedade? A investigação científica sobre o surgimento e desenvolvimento das políticas sociais, ao reconhecer os seus aspectos contraditórios, abre uma série de possibilidades de análise. Essas possibilidades enriquecem a investigação, mas também tornam desafiante a apreensão das políticas sociais. 
É comum haver afirmações no sentido de que, pelas contradições inerentes a uma sociedade capitalista, as políticas sociais são funcionais ao capitalismo (BEHRING; BOSCHETTI, 2008; PERISSINOTTO, 2010). Isto é, ao ampliar as noções de cidadania experimentadas pelos sujeitos beneficiados pela ação pública, as políticas sociais são malefícios por contribuírem para a manutenção das condições de reprodução das desigualdades no interior da sociedade capitalista, ao invés de buscar eliminar as condições que impedem a instalação de uma sociedade fundada em outras bases materiais. Entretanto, ao afirmar que uma política social é funcional ao capitalismo, não há nenhuma explicação a respeito das contradições que constituíram a natureza das relações de tal política, bem como suas possibilidades e limites para a manutenção e expansão das mesmas. Grande parte das explicações do tipo funcional pode decorrer, inclusive, do marxismo e foi contestada, principalmente pela corrente denominada de marxismo analítico (COHEN, 1989; ELSTER, 1982; ROEMER, 1982).

O projeto do marxismo analítico consiste essencialmente na rejeição dos pressupostos do marxismo tradicional a respeito da atuação do Estado, das políticas públicas, do caráter político assumido por determinados representantes da classe dominante etc. Para os autores dessa corrente teórica, é preciso, primeiro, rejeitar as pretensões dos marxistas à especificidade metodológica e, segundo, fazer a crítica de muitos dos seus procedimentos científicos (PERISSINOTTO, 2010). Na verdade, segundo os marxistas analíticos, em especial Jon Elster, o grande problema metodológico do marxismo "tão grande a ponto de impedi-lo de fazer ciência é exatamente seu método, baseado em termos gerais em declarações do tipo funcional sem capacidade explicativa" (PERISSINOTTO, 2010, p. 2). De forma resumida, o que os marxistas analíticos passaram a criticar é que grande parte das alegações, por exemplo, feitas pela análise marxista tradicional a respeito das políticas gestadas pelo Estado é que elas são benéficas à classe dominante. Entretanto, como assinala Renato Perissinotto (2010), o marxismo analítico defende que a explicação do tipo funcional não é uma explicação; é tão somente uma alegação.

Há uma infinidade de alegações sobre as políticas sociais ou sobre o comportamento do Estado como fenômenos funcionais à reprodução da dominação de classe e da manutenção das condições de desigualdade entre os indivíduos na sociedade capitalista (PERISSINOTTO, 2010). Isso quer dizer que, ao afirmar que uma política social é benéfica para alguma ação do Estado capitalista porque auxilia nas condições de reprodução das desigualdades de uma sociedade, está se inferindo que essa é a razão da existência e manutenção de tal política. Essa 
afirmação não é totalmente verdadeira e comprovável. Se as políticas sociais têm como efeito imprevisível ou incontrolável o benefício da classe dominante, de outra ação do Estado ou da própria sociedade em suas contradições, nada a respeito da natureza ou das relações constitutivas da política social e suas dinâmicas foi dito.

Para Jon Elster, há uma fraqueza lógica nesse tipo de inferência funcional porque "a questão está em como explicar um fenômeno a partir de outro que acontece depois. Deve haver uma explicação para um fenômeno no momento de sua ocorrência; não pode ser necessário esperar pelas consequências para só então poder explicá-lo" (1982, p. 46). Ou seja, explica-se insatisfatoriamente a causa das limitações das políticas sociais pelo efeito trazido para a sociedade. Nas explicações do tipo funcional, as investigações a respeito das relações estruturantes das políticas sociais e de seu caráter expansivo ou limitado ocorrem equivocadamente pelos seus efeitos na sociedade e não pelos fenômenos que a gestaram.

Numa passagem dos escritos de Karl Marx, o autor assinala o seguinte:

O que é a sociedade, qualquer que seja a sua forma? O produto da ação recíproca dos homens. Os homens podem escolher, livremente, esta ou aquela forma social? Nada disso. A um determinado estágio de desenvolvimento das faculdades produtivas dos homens corresponde determinada forma de comércio e consumo. A determinadas fases de desenvolvimento da produção, do comércio e do consumo correspondem determinadas formas de constituição social, determinada organização da família, das ordens ou das classes, numa palavra, uma determinada sociedade civil. A uma determinada sociedade civil corresponde um determinado estado político, que não é mais que a expressão oficial da sociedade civil. [...] É supérfluo acrescentar que os homens não são livres para escolher as suas forças produtivas — base de toda a sua história -, pois toda força produtiva é uma força adquirida, produto de uma atividade anterior. Portanto, as forças produtivas são o resultado da energia prática dos homens, mas essa mesma energia é circunscrita pelas condições em que os homens se acham colocados, pelas forças produtivas já adquiridas, pela forma social anterior, que não foi criada por eles e é produto da geração precedente. $\mathrm{O}$ simples fato de cada geração posterior deparar-se com forças produtivas adquiridas pela geração precedente cria na história dos homens uma conexão, cria uma história da humanidade. [...] As suas relações materiais formam a base de todas as relações $(2009$, p. 245$)$.

Essa longa citação dos escritos de Marx dá uma dimensão de sua perspectiva sobre a análise das relações sociais. Ela norteia este estudo na medida em que pode delimitar o quadro de análise a partir do qual as políticas de saúde mental e de assistência social conformam um cenário específico no Brasil a partir dos anos 1990 e 2000. Essas duas políticas serão examinadas a fim de buscar explicações para a emergência dos indivíduos esquecidos dos manicômios judiciários no momento em que essas políticas adquirem novas formas e novas bases, guardando, entretanto, laços com determinantes do passado. 
A gênese de um fenômeno não pode ser explicada de modo funcional porque é equivocado do ponto de vista lógico: as causas devem ser anteriores ao fenômeno que se pretende explicar (PERISSINOTTO, 2010). Para escapar dos reducionismos das explicações do tipo funcional e continuar assumindo os pressupostos acerca das políticas sociais como instâncias localizadas e significadas a partir das contradições inerentes ao modo de produção capitalista, é preciso dispor de metodologias de investigação capazes de superar procedimentos que reforçam as explicações do tipo funcional. Tais investidas não são simples. Neste estudo, buscar-se-á reafirmar a perspectiva de que as políticas sociais não superam as manifestações da questão social introduzida pelo capitalismo. No máximo, podem criar barreiras na medida em que ampliam as mudanças sociais decorrentes das políticas sociais que materializam direitos de cidadania.

Partindo dessas ideias para explicar o que está por trás da emergência dos esquecidos dos manicômios judiciários brasileiros, a metodologia de estudo que embasou a análise empírica desta tese foi do tipo misto, com métodos qualitativos e quantitativos de levantamento e análise de dados. Utilizou-se a técnica de análise de política pública, o método genealógico e um estudo de caso com três fases. No primeiro momento, foi realizada uma análise da legislação e das políticas de assistência social e de saúde mental a fim de avaliar os limites às garantias dos direitos das pessoas em medida de segurança e o quanto essas ações podem favorecer ou não o processo de desinternação dos indivíduos. Essa análise investigou os traços capazes de demarcar o familismo nas políticas de assistência social e saúde mental. Desse modo, ao analisar a efetividade de tais ações para os indivíduos em medida de segurança na fase de desinternação, verificou-se o quanto o alcance, limitado ou não, dessas políticas pode ser explicado pelo familismo. Em segundo lugar, foi feita uma análise quantitativa e qualitativa dos dados da publicação A custódia e o tratamento psiquiátrico no Brasil - censo 2011 referentes aos indivíduos que estavam indevidamente em restrição de liberdade nos manicômios judiciários, com o objetivo de apresentar um perfil sociodemográfico, psiquiátrico e penal dessas pessoas e mostrar particularidades dessa situação. Essa população específica ainda não teve seus dados analisados por nenhum estudo, apenas foi apresentado, no censo de 2011, o número total de pessoas internadas indevidamente nos ECTPs e os motivos da internação. Por último, foi realizado um estudo de caso na Vara de Execuções Penais do Tribunal de Justiça do Distrito Federal e Territórios (TJDFT) responsável pela execução das medidas de segurança no Distrito Federal. Avaliaramse, nesse momento, os itinerários e desafios da desinternação na interface com as políticas de 
assistência social e saúde mental.

\subsection{Fases da pesquisa: análise de política pública e genealogia, dados quantitativos e estudo de caso no Distrito Federal}

\subsubsection{Análise de política pública}

A primeira fase da pesquisa foi uma análise das políticas de assistência social e saúde mental, a fim de investigar a capacidade dessas políticas em auxiliar a justiça e a administração penal no momento da desinternação dos indivíduos em medida de segurança. Há benefícios da política de saúde mental destinados às pessoas em sofrimento mental, como os Serviços Residenciais Terapêuticos e o auxílio-reabilitação De Volta para Casa, que busca criar autonomia e prover necessidades básicas dos indivíduos em sofrimento mental que tenham laços familiares rompidos (BRASIL, 2000, 2003). Por algum motivo, essas políticas não são efetivas para os indivíduos que cumpriram medida de segurança. Por isso, foi feita uma análise dessas políticas a fim de levantar seus desafios de materialização no caso dos indivíduos que cumpriram medida de segurança.

No caso da política de assistência social, também há benefícios e ações destinadas especificamente aos indivíduos em sofrimento mental e às suas famílias que poderiam criar condições efetivas de garantir necessidades básicas àqueles em medida de segurança na fase de desinternação. Exemplo disso é o Benefício de Prestação Continuada da Assistência Social (BPC), voltado para pessoas com deficiência física, intelectual (mental) e sensorial que vivem na extrema pobreza (BRASIL, 2011b). O BPC é um benefício assistencial de transferência de renda no valor de um salário mínimo garantido às pessoas mensalmente, de acordo com previsão constitucional expressa no artigo 203 (BRASIL, 1988). Neste estudo, analisou-se esse benefício e demais programas, serviços e benefícios da assistência social na perspectiva de diagnosticar os desafios de sua efetivação para as pessoas que cumpriram medida de segurança.

Análise de política pública pode ser definida como um conjunto de elaborações sobre conhecimentos produzidos em diversas disciplinas das ciências humanas, objetivando analisar e resolver problemas concretos em políticas públicas (DAGNINO, 2000). Ou seja, o conhecimento acerca das políticas públicas vislumbra interpretar as causas e as consequências das atuações dos governos na elaboração, na implementação e no acompanhamento de determinada ação política voltada para resultados, com alocação de recursos e desenho para 
longa duração. Nos Estados Unidos, essa vertente de pesquisa em ciência política começou a se instituir já no início dos anos 1950, em ambiente influenciado pelo keynesianismo sob o rótulo de policy science (DAGNINO, 2000; FREY, 2000). Já na Europa, em particular na Alemanha, a preocupação com determinados campos de políticas e ações públicas tomou maior delineamento a partir do início dos anos 1970, com a ascensão da social-democracia. No caso brasileiro, a análise de políticas públicas só foi ganhar espaço, ainda que de maneira incipiente e frágil, no decorrer dos anos 1990 e 2000 (FREY, 2000).

Um modelo de análise de políticas públicas não pode desconsiderar alguns aspectos da sociedade, tais como processos políticos, estabilidade institucional e perfis históricos das ações estatais e governamentais, com o objetivo de atentar para uma teia de fatores que determinam a configuração dos perfis de tais políticas. Assim, é imprescindível delimitar o espaço e o alcance dos conhecimentos produzidos por meio da análise de políticas públicas. A análise de política pública está preocupada, sobretudo, com o que, como e por que o governo toma alguma atitude, geralmente, na tentativa de aperfeiçoar um tema, ou de prevenir algum aspecto indesejado (DAGNINO, 2000; HALL; TAYLOR, 2003). Esse tipo de análise visa, ainda, compreender se a gerência de tal ação aponta na direção de alguma determinação de alocação de poder, além da alocação de recursos destinados à garantia de direitos já assegurados pela sociedade (BUCCI, 2006). Em síntese, a análise de política revela quase sempre as características sociais, políticas e históricas presentes na relação da sociedade com o Estado (DAGNINO, 2000; FREY, 2000).

A análise de uma política pública impõe desafios que estão além da descrição e compreensão dos resultados da ação do Estado, pois se trata de um questionamento, sobretudo, acerca das bases da democracia (MÜLLER; SUREL, 2002). De modo geral, uma análise de políticas públicas costuma ser dividida em três fases sucessivas — formulação, implementação e avaliação - que conformam um ciclo que se realimenta (DAGNINO, 2000). Contudo, uma corrente denominada social analysis possui uma categoria classificada de ciclo da política (policy cycle), que divide a análise de política de forma mais abrangente, em cinco etapas: 1. percepção e definição de uma questão a ser enfrentada por meio de uma ação específica; 2. agenda setting, ou seja, o modo como determinado tema ascende ao patamar de questão com urgência de intervenção de uma ação estruturada e racionalizada; 3. elaboração de um programa e da decisão; 4. implementação da política; 5. avaliação da política e eventual correção das ações (FREY, 2000). Todavia, esse modelo de análise recebeu constantes críticas, sobretudo, pela simplificação de processos tidos como mais complexos e 
pela pouca teorização dos processos políticos sobre os quais se tornava possível uma análise de política - ainda que, para muitos teóricos e especialistas em análises de políticas, tais críticas se revelassem frágeis e não abalassem a força analítica da modalidade social analysis (FREY, 2000).

Segundo Renato Dagnino (2000), existem variedades de tipos de análises de políticas públicas, que por sua vez possuem distintas características e procedimentos metodológicos. Estudo de elaboração, estudo de resultados, estudo de conteúdo, avaliação de políticas e impacto, defesa de processo de elaboração e defesa de políticas são alguns exemplos. Para a presente pesquisa sobre a capacidade das políticas de assistência social e de saúde mental contribuírem na fase de desinternação dos indivíduos em medida de segurança, será feito uso, principalmente, da modalidade estudo de conteúdo de política pública. Nessa modalidade, é possível gerar conhecimentos após a análise da gênese e a explicação do desenvolvimento de determinada política pública, isto é, descrever como ela foi implementada e quais os resultados e limites encontrados, os atores envolvidos no acompanhamento, o estágio de implementação em que ela se encontra, as barreiras na implementação e as alternativas para solucioná-las etc. (DAGNINO, 2000). Ter clareza sobre tais fases permite melhor localizar o objeto do presente estudo.

As análises das políticas de assistência social e saúde mental foram realizadas por meio do estudo de decretos, portarias, leis, atos normativos internos e notas técnicas que dizem respeito a programas, benefícios ou serviços da assistência social e da política de saúde mental voltadas para a população em medida de segurança. Aqui se compreende política de saúde mental basicamente como o conjunto de ações formado por programas, serviços e benefícios criados com o Movimento da Reforma Psiquiátrica e com a Lei 10.216, de 2001, e voltados para a atenção psicossocial da população em sofrimento mental. E entende-se a política de assistência social principalmente como os serviços, benefícios e programas criados com a Lei Orgânica da Assistência Social (LOAS), de 1993, a Política Nacional de Assistência Social, de 2004, e o Sistema Único de Assistência Social, de 2005. Há um conjunto de benefícios e serviços voltados a pessoas com deficiência, pessoas com doença ou transtorno mental, pessoas que vivem na pobreza e pessoas que possuem incapacidade laborativa; e há algumas poucas ações de assistência social e de saúde mental voltadas especificamente para as pessoas egressas dos ECTPs que cumpriram medida de segurança. É diante dessa lacuna das duas políticas que esta tese buscará respostas para a situação daqueles 
indivíduos que já cumpriram os critérios para o livramento, mas permanecem internados nos ECTPs.

\subsubsection{Análise do estudo censitário dos manicômios judiciais}

Na segunda fase da pesquisa, foi realizada uma análise quanti-qualitativa dos dados do estudo A custódia e o tratamento psiquiátrico no Brasil - censo 2011, conduzido pelo Ministério da Justiça e pela Anis - Instituto de Bioética, Direitos Humanos e Gênero e publicado em 2012 (DINIZ, 2012). Esse censo teve o objetivo de levantar três tipos de informação sobre a população que vivia nos 26 ECTPs do país: informações sociodemográficas, informações sobre diagnósticos e informações do itinerário penal dos indivíduos antes e durante o cumprimento das medidas de segurança. Esse foi um estudo inédito no Brasil com essa população, cujo perfil pôde então ser delineado para fins de adequação das políticas públicas voltadas a essas pessoas.

Os dados do censo nesta tese dizem respeito às pessoas que continuavam vivendo nos ECTPs apesar de já terem cumprido todos os requisitos jurídicos para sua desinternação: os esquecidos. A análise aprofundada dos dados dessa população teve o objetivo de mostrar um perfil nacional desses indivíduos. Embora seja importante esse perfil, o estudo censitário publicado em 2012 não levantou informações sobre por que tais situações acontecem. No quinto capítulo desta tese, serão apresentados e contrastados os dados da população que já deveria estar em liberdade com os dados dos demais indivíduos em medida de segurança.

Os dados analisados dos dois grupos foram: faixa etária, sexo, situação conjugal, cor/raça, escolaridade, profissão, situação da internação, crime cometido, recidiva, crime contra a família, tempo de internação, total da população nas duas situações por ECTP, quantidade de internações por paciente e diagnóstico psiquiátrico. $\mathrm{Na}$ publicação do estudo censitário, em 2012 (DINIZ, 2012), esses dados não estavam desagregados. Houve a categorização do público geral entre pessoas em medida de segurança e pessoas em situação de internação temporária. Na sequência, contabilizaram-se os indivíduos em situação de restrição de liberdade indevida por já terem cumprido os critérios para a desinternação. A análise aprofundada desse universo, bem como o contraste aos demais em medida de segurança, pode ser importante para o conjunto das reflexões abordadas nesta tese, principalmente no que diz respeito a fornecer subsídios para a testagem da hipótese central da pesquisa. 
Comparar as duas populações (os esquecidos e as demais pessoas em medida de segurança dos manicômios judiciários) quanto aos perfis sociodemográficos, de itinerário penal e das condições de saúde pode oferecer subsídios para aprofundamentos a respeito da realidade desses indivíduos. Essa comparação, por um lado, descortina a realidade dos esquecidos com o intuito, inclusive, de favorecer estudos futuros a respeito de traços distintos dessa parcela da população dos manicômios judiciários. Por outro, elucida em que medida os traços característicos da população dos esquecidos podem influenciar essa situação de permanência em restrição indevida de liberdade.

\subsubsection{Estudo de caso no Distrito Federal}

A apresentação dos dados gerais da população dos esquecidos dos manicômios judiciários ganha mais relevância desde que uma metodologia de análise permita aprofundar os dados em conjunturas específicas. Com esse objetivo, foi conduzido, em 2013, um estudo de caso na Ala de Tratamento Psiquiátrico do Distrito Federal (ATP-DF), que é um dos ECTPs do país e teve seus dados levantados no censo. O objetivo do estudo de caso para compor esta tese foi aprofundar a análise da fase de desinternação dos indivíduos em medida de segurança. Na ATP-DF, em 2011, ao menos 17\% (14) dos 62 indivíduos em medida de segurança não deveriam estar internados por terem a periculosidade cessada ou por terem sentença de desinternação ou medida de segurança extinta, ou ainda por terem sido internados sem processo judicial (DINIZ, 2012).

Um estudo de caso representa a estratégia de pesquisa mais adequada quando se tenta responder a questões do tipo "como" e "por que", sobretudo quando o pesquisador tem pouco controle sobre os acontecimentos e o foco da investigação são fenômenos contemporâneos inseridos no contexto da vida cotidiana (YIN, 2005). Para Robert K. Yin (2005), o estudo de caso permite uma investigação para preservar 1. as características holísticas, ou seja, há um enfoque teórico que pretende estudar os diversos aspectos da realidade como um todo e 2. as características significativas dos acontecimentos da vida cotidiana. Essa estratégia de pesquisa vem sendo muito utilizada em áreas como psicologia, sociologia, ciência política, serviço social, administração e economia (YIN, 2005).

Para Stake (1994), os estudos de caso mostram-se valiosos ao acrescentar entendimento, ampliar a experiência e aumentar a convicção sobre um tema. Um ponto importante é que um estudo de caso é recomendado com a mixagem de outras metodologias 
na pesquisa qualitativa, como se faz nesta tese. Fases anteriores de levantamento de dados indicaram caminhos a serem investigados durante o estudo de caso. A escolha do Distrito Federal para realizar o estudo de caso se deveu à possibilidade de empregar essa metodologia em profundidade. A ATP-DF não tem nada que a particularize perante os demais 25 ECTPs do país. O tamanho de sua população se aproxima da média dos 26 ECTPs, de acordo com o estudo censitário apresentado em 2012 (DINIZ, 2012). Além disso, a possibilidade de realizar um trabalho de campo mais cuidadoso - pois, seria possível o retorno constante ao campo em função do Distrito Federal ser o local de residência do pesquisador responsável pela tese - pode produzir uma análise aprofundada das políticas de assistência social e de saúde mental na fase de desinternação no Distrito Federal, dado que, no estudo de caso, "a coleta de dados deve ser revisada repetidamente" (GRAY, 2012, p. 211), em um campo que permita essa coleta pormenorizada. Além disso, "os estudos de caso se beneficiam com o desenvolvimento anterior de uma posição teórica para ajudar a direcionar o processo de coleta e análise de dados" (GRAY, 2012, p. 201), pois tentam estabelecer relações causais entre os fenômenos investigados e não apenas descrever uma situação (GRAY, 2012).

No estudo de caso, tanto a hipótese quanto as perguntas de pesquisa devem estar relacionadas a pesquisas anteriores (GRAY, 2012). Nesta tese, estudos prévios e fases anteriores de levantamento e análise de dados, como foi a de análise de política pública no campo da assistência social e de saúde mental, antecederam à fase de estudo de caso na ATPDF. Em termos de coleta de dados, o método do estudo de caso requer o uso de múltiplas fontes, o que pode incluir entrevistas estruturadas e semiestruturadas, análise documental e observações de campo (GRAY, 2012), como também ocorreu neste estudo. Todas essas formas de coleta de dados foram utilizadas no estudo de caso no Distrito Federal.

David Gray (2012) classifica em quatro os tipos de estudo de caso: estudo de caso único e holístico, estudo de caso múltiplo e holístico, estudo de caso único e combinado e estudo de caso múltiplo e combinado. O estudo de caso desta tese foi do tipo múltiplo e holístico. Nele, há uma única unidade de análise definida (os indivíduos em medida de segurança em fase de desinternação), mas o estudo envolve casos múltiplos na relação com a totalidade do fenômeno observado. Nesse sentido, o estudo de caso se aproxima de um estudo do tipo experimentação, em que se faz uma tentativa de replicar as análises para conclusões de um experimento em vários casos, a fim de emprestar sustentação contundente a um conjunto de proposições (GRAY, 2012). 
Foram analisados 40 processos de indivíduos em medida de segurança da ATP-DF, sendo 23 processos de medidas de segurança extintas e 17 de medidas de segurança em processo de desinternação. Todos eram referentes ao ano de 2013. A pesquisa de campo ocorreu entre 5 de novembro de 2013 e 30 de janeiro de 2014. Foi elaborada uma ficha eletrônica de registro das informações com a finalidade de armazenar os dados coletados dos processos ou dossiês analisados (Apêndice B). A ficha continha 30 quesitos, entre questões objetivas e qualitativas para recuperação de informações sobre a fase de desinternação dos indivíduos. A inclusão de processos de medidas de segurança já em fase de extinção e de desinternação teve o objetivo de enriquecer a análise do itinerário da desinternação, desde os momentos iniciais até sua conclusão, assim como daqueles casos das medidas já extintas.

No estudo de caso na ATP-DF, três técnicas de levantamento de dados foram utilizadas:

1. análise documental dos dossiês dos indivíduos em medida de segurança. O conceito de dossiê é utilizado para designar uma pasta de informações que agrupa um conjunto de documentos sobre uma ação, evento ou pessoa e constitui uma unidade de arquivamento (BRASIL, 2003; CUNHA, 2008). Os dossiês possuem nomes diferentes nos ECTPs do país, como "pastas de informações”, "processos", "prontuários jurídicos”, “papeletas” ou, simplesmente, "arquivos". Os dossiês da população da ATP-DF agrupam os documentos contendo informações a respeito do andamento da execução da medida de segurança ou da situação de internação temporária do indivíduo, tais como despachos, exames de sanidade mental, exames de cessação de periculosidade e comunicações da defesa. Os dossiês arquivam também as comunicações institucionais entre o ECTP, as Varas de Execuções Penais e as delegacias, além de conterem cópias de peças dos processos judiciais, no caso das medidas de segurança, tais como investigação policial, autos de prisão, inquérito, habeas corpus, livramentos, denúncias, sentenças e recursos;

2. mapeamento da rede socioassistencial e psicossocial que permite o acompanhamento dos indivíduos em medida de segurança em situação de desinternação no DF;

3. por último, entrevistas com os profissionais da Vara de Execuções Penais (VEP) responsáveis por promover a articulação das ações e iniciativas capazes de 
auxiliar os indivíduos no momento da desinternação. Foram realizadas cinco entrevistas com cinco profissionais: uma assistente social, um psicólogo e três analistas judiciários com formação em direito.

As técnicas de levantamento de dados no estudo de caso da ATP-DF estão de acordo com o que indica Gray (2012). Para esse autor, uma das técnicas mais importantes de estudo de caso é o levantamento de evidências em documentação ou arquivo. Nesse tipo de técnica de levantamento de dados, a análise documental ou de arquivos tem como ponto forte o fato de ser um levantamento estável, por poder ser revisada repetidamente. Além disso, é uma técnica não invasiva - não criada como resultado do estudo de caso - , isto é, os arquivos, documentos e processos analisados já existiam antes da pesquisa. A técnica de levantamento de dados em processos da VEP-DF, que continham detalhes precisos, permitiu um levantamento mais exato, com cobertura ampla de tempo e dos contextos analisados, como foi o acompanhamento de processos relativos a um ano de itinerário de desinternação dos indivíduos em medida de segurança.

\subsection{Método genealógico}

É atribuído às pesquisas em que Foucault se dedica à análise das formas de poder o período genealógico, a exemplo das obras Vigiar e punir, Os anormais e $O$ poder psiquiátrico. À diferença do que ocorre na fase da arqueologia do autor, como na obra $A$ arqueologia do saber (2000), Foucault não escreveu uma obra metodológica a respeito do método genealógico (CASTRO, 2009). Há uma série de princípios metodológicos para abordar a análise do poder na perspectiva genealógica, que se encontra principalmente em Vigiar e punir (1977), e serão esses princípios que guiarão o método genealógico empregado nesta tese. A passagem da fase da arqueologia para a da genealogia nos escritos de Foucault é uma ampliação do campo de investigação para incluir de maneira mais precisa o estudo das práticas não discursivas, ou seja, para analisar o saber em termos de estratégias e táticas de poder (CASTRO, 2009).

Para Foucault (1977, 2003b), a pesquisa genealógica busca explicar os fatores históricos que têm a capacidade de dar origem e sustentação às formas atuais das práticas, dos dispositivos, dos saberes e das instituições que conhecemos. Nesta tese, a genealogia foi empregada na análise de conteúdo (DAGNINO, 2000) das políticas de assistência social e de 
saúde mental a fim de investigar como, no desenvolvimento dessas políticas, emergiram fenômenos que fizeram com que tais ações encontrassem barreiras para a ampliação para os indivíduos em medida de segurança, mesmo quando alterações recentes no arcabouço das duas políticas parecem anunciar avanços em suas concepções contemporâneas.

A partir dos anos 2000, tanto a política de assistência social quanto a de saúde mental promoveram - cada uma a seu modo - uma ruptura com determinantes históricos que faziam com que suas ações assumissem perspectivas conservadoras no tocante à promoção da cidadania dos indivíduos. Nos anos 1990 e 2000, a assistência social e a política de saúde mental passaram a se assentar sobre novas bases, o que permitiu ampliar sua cobertura. No entanto, cada uma esbarrou também em limitações e parece não ter conseguido se desvencilhar de todos os princípios e valores tradicionais que influenciaram na limitação de suas práticas no passado e, de forma persistente, continuam a delineá-las no presente.

Utilizar o método genealógico como estratégia para analisar o conteúdo das políticas de assistência social e de saúde mental teve o objetivo de descortinar os determinantes históricos essenciais das características que, ainda hoje, podem ter influência sobre as duas políticas públicas. O método genealógico é um empreendimento que busca nos escombros do passado a força que ilumina as arquiteturas do presente (VEYNE, 2011). Em outras palavras, a preocupação histórica na genealogia não busca compreender criticamente os meandros do passado, mas entender as condições históricas de existência pelas quais se tornou possível o engendramento das práticas acessíveis na contemporaneidade.

Nesta tese, buscou-se realizar uma genealogia nas políticas de assistência social e de saúde mental em busca de traços do familismo nessas duas ações. Compreender as contradições inerentes à formulação e execução das políticas sociais é investigar seus meandros, suas conjecturas do passado que refletem, nos perfis do presente, as condições de possibilidade de emergência do status atual de determinada ação pública. O método genealógico aqui utilizado buscou oferecer forças explicativas para o modo como as políticas de assistência social e de saúde mental se inter-relacionam com as demandas das pessoas em sofrimento mental que, na fase da desinternação condicional das medidas de segurança, necessitam de assistência pública para a tomada de decisão, para o atendimento de suas necessidades básicas e, consequentemente para a promoção da autonomia dos indivíduos em sofrimento mental.

Para Foucault (1977, 2003b), toda sociedade, como construção histórica, tem seu suporte em práticas discursivas que a atravessam, criando as possibilidades para que surja 
uma formação discursiva própria, porém inter-relacionada com o macrocontexto. Para tanto, a apreciação dos conceitos de acontecimento, série, regularidade e condições de possibilidade se faz necessária na perspectiva foucaultiana. Segundo Foucault (1977), o acontecimento é o conjunto de forças presentes no meio que possibilitam a emergência de determinada prática, em substituição à criação ou ao ponto de origem de outra. Por sua vez, a noção de série relaciona a análise em relação ao tema como multiplicidades determináveis historicamente, em substituição à unidade de uma obra como continuidade e estabilidade. Paralelamente à noção de série, a regularidade estabelece que são regras do campo onde as singularidades se distribuem e se reproduzem, em substituição à originalidade, evitando recorrer à ideia de originalidade centrada em um indivíduo. Por fim, a noção de condições de possibilidade são alternativas abertas no campo como resultado das relações de força que definem as opções de emergência, em substituição à ideia de significação (FOUCAULT, 1977).

$\mathrm{Na}$ relação entre acontecimento, série, regularidade e condição de possibilidade, o método genealógico busca o desenvolvimento histórico dos saberes, das práticas e dos dispositivos, ou seja, a explicação dos fatores que interferem na sua emergência, permanência e adequação ao campo discursivo, defendendo sua existência como elementos incluídos em um dispositivo político. Na análise das políticas de assistência social e de saúde mental, ficam demarcados os momentos em que o acontecimento, a série, a regularidade e a condição de possibilidade estão presentes nas rupturas e continuidades que as duas políticas experimentaram, a partir dos anos 2000, no que diz respeito à presença do familismo. Isso se deu mesmo quando essas duas políticas passaram a se estruturar em novas bases na perspectiva da ampliação de seu alcance, agora, de modo articulado à garantia dos direitos de cidadania dos indivíduos.

A genealogia estuda a formação de saberes, práticas, dispositivos e instituições para caracterizar tal formação ao mesmo tempo dispersa, descontínua e irregular (FOUCAULT, 1977, 2003b). Para Edgardo Castro (2009), a genealogia não opõe a multiplicidade concreta dos fatos à unidade abstrata da teoria. Não chega a ser um empirismo ou um positivismo no sentido ordinário do termo. O método genealógico tenta, antes de qualquer coisa, fazer oposição aos saberes locais, descontínuos, desqualificados, não legitimados, contra a instância teórica, unitária, que pretende filtrá-los, hierarquizá-los, ordená-los em nome de um conhecimento verdadeiro (CASTRO, 2009). Nesse ponto, Foucault entende a genealogia como uma atividade de investigação trabalhosa, que procura os indícios nos fatos desconsiderados, desvalorizados e mesmo apagados pelos procedimentos da história 
tradicional, na busca da confirmação de suas hipóteses. A genealogia escuta a história, prestando atenção a seus acasos e suas descontinuidades, pois, se há algo a decifrar, algum segredo a desvendar, é que as coisas não têm essência, ou melhor, a suposta essência foi deliberadamente construída com base em situações específicas, contextualizadas histórica e socialmente (FOUCAULT, 1977). Para Foucault (2003b), a própria razão nasceu do acaso, da paixão dos cientistas, de sua busca incessante de verdade, de suas discussões fanáticas, enfim, de sua vontade de saber e de sua necessidade de suprimir as paixões. O que dá forma a todas as coisas emergentes não é uma suposta identidade baseada na origem, mas a discórdia na relação entre as coisas (FOUCAULT, 2003b).

Cabe salientar que o método genealógico não busca avaliar o passado em nome de uma nova verdade, mas de uma análise dos dispositivos enquanto atravessados pela vontade de verdade. Isto é, visa entender como certa definição de um saber ou de uma prática que teve uma origem qualquer atravessa o tempo metamorfoseando-se ao ponto de entrar em um dispositivo que faz dela uma realidade (VEYNE, 2011). A genealogia seria o estudo das formas de poder “[...] na sua multiplicidade, nas suas diferenças, na sua especificidade, na sua reversibilidade: estudá-las, portanto, como relações de força que se entrecruzam, que remetem umas às outras, convergem ou, ao contrário, se opõem [...]” (FOUCAULT, 2003, p. 71). O que a genealogia se propõe é desenvolver uma concepção não jurídica do poder, do saber, das práticas e dos dispositivos. Ou seja, não se pode dar conta do poder e das práticas se eles são caracterizados como algo que diz respeito fundamentalmente à lei e à repressão.

Para Foucault, as pretensões do método genealógico seriam,

em relação ao projeto de inscrição dos saberes na hierarquia do poder próprio da ciência, uma espécie de empreendimento para desassujeitar os saberes históricos e torná-los livres, isto é, capazes de oposição e de luta contra a coerção de um discurso teórico unitário, formal e científico (FOUCAULT, 2003b, p. 11).

A crítica de Foucault (1977) segue em duas direções: a primeira diz respeito às teorias dos filósofos do século XVIII, que definem o poder como direito originário que se cede para constituir a soberania e que tem como objeto o contrato social; a segunda, às teorias que fazem a crítica do abuso do poder, caracterizando não somente o poder por transgredir o direito, mas o próprio direito por ser um modo legal de exercício da violência do Estado. Nesse sentido, o Estado teria o papel central de realizar a repressão, isto é, o poder como uma espécie de violência legalizada. Foucault está preocupado principalmente com o caráter 
positivo dos efeitos de poder, com aquilo que ele é capaz de produzir, mais do que com aquilo que ele é capaz de aniquilar.

Em Vigiar e punir, Foucault (1977) afirma ser preciso evitar sempre descrever os efeitos do poder em termos negativos: 'ele exclui', ele 'reprime', ele 'recalca', ele 'censura', ele 'abstrai', ele 'mascara', ele 'esconde'. De fato, o poder produz. Produz realidade, produz domínios de objetos e rituais de verdade. O indivíduo e o conhecimento que dele se pode ter se originam nessa produção. Temos que admitir que o poder produz saber (e não simplesmente favorecendo-o porque serve a ele ou aplicando-o porque é útil); que poder e saber estão diretamente implicados; e que não há relação de poder sem a constituição correlata de um campo de saber, nem saber que não suponha e não constitua, ao mesmo tempo, relações de poder.

Essas relações de poder-saber não devem ser analisadas a partir de um sujeito de conhecimento que seria ou não livre em relação ao sistema de poder; é preciso considerar, ao contrário, que o sujeito que conhece, os objetos a conhecer e as modalidades de conhecimento são outros tantos efeitos fundamentais do poder-saber e de suas transformações históricas. Nas palavras de Foucault (1977, p. 228-229), o objetivo de seu trabalho foi "mostrar como o acoplamento entre uma série de práticas e um regime de verdade forma um dispositivo de saber-poder”. Resumindo, não é a atividade do conhecimento que produziria um saber, útil ou arredio ao poder, mas principalmente o poder-saber, os processos e as lutas que o atravessam e o constituem que determinam as formas e os campos possíveis do conhecimento.

Em período posterior, Foucault (2003b) priorizaria as práticas sobre as teorias, saindo de uma posição contemplativa de discursos ao introduzir a genealogia como um modo de problematizar as práticas sociais de dentro. $\mathrm{O}$ autor sinaliza que "a genealogia [...] se opõe à pesquisa de origem [...], o genealogista necessita da história para conjurar a quimera de origem" (FOUCAULT, 2003b, p. 16 e 19). Não há uma finalidade na história, assim como não há uma origem; os acontecimentos emergem ao acaso das forças, e não de uma intenção ou determinação prévia. Foucault defende que o genealogista precisa ter o cuidado de escutar a história em vez de acreditar na metafísica. Se fizer isso, o que ele aprende? "Que atrás das coisas há 'algo inteiramente diferente': não seu segredo sem data, mas o segredo que elas são sem essência, ou que sua essência foi construída peça por peça a partir de figuras que lhe eram estranhas" (FOUCAULT, 2003b, p. 16 e 19).

A genealogia é entendida como análise da proveniência e história das emergências, dos acontecimentos. A proveniência não funda, não aponta para uma continuidade, não é uma 
categoria de semelhança (FOUCAULT, 2003b). Perguntar pela proveniência de um indivíduo, de um sentimento ou de uma ideia não é descobrir suas características genéricas para assimilá-los a outros, nem mostrar que neles o passado ainda está vivo, muito menos encontrar o que pôde fundá-lo; é, na verdade, buscar suas marcas diferenciais, repertoriar desvios e acidentes de percurso, apontar heterogeneidades sob o que se imagina conforme a si mesmo. A emergência, por sua vez, não se confunde com o termo final de um processo. A pesquisa da proveniência "não funda, muito pelo contrário: ela agita o que se percebia imóvel, ela fragmenta o que se pensava unido; ela mostra a heterogeneidade do que se imaginava em conformidade consigo mesmo" (FOUCAULT, 2003b, p. 22). Ao indagar sobre a emergência de um órgão ou de um costume, não se trata de explicá-los pelos antecedentes que os teriam tornado possíveis, mas de mostrar o ponto de seu surgimento; não cabe compreendê-los a partir dos fins a que se destinariam, mas detectar certo estado de forças em que aparecem. Para Foucault,

\begin{abstract}
a genealogia não pretende recuar no tempo para restabelecer uma grande continuidade para além da dispersão do esquecimento; sua tarefa não é a de mostrar que o passado ainda está lá, bem vivo no presente, animando-o ainda em segredo, depois de ter imposto a todos os obstáculos do percurso uma forma delineada desde o início. Nada que se assemelhasse à evolução de uma espécie, ao destino de um povo. Seguir o filão complexo da proveniência é, ao contrário, manter o que se passou na dispersão que lhe é própria: é demarcar os acidentes, os ínfimos desvios — ou ao contrário as inversões completas -, os erros, as falhas na apreciação, os maus cálculos que deram nascimento ao que existe e tem valor para nós; é descobrir que na raiz daquilo que nós conhecemos e daquilo que nós somos - não existem a verdade e o ser, mas a exterioridade do acidente (2003b, p. 22).
\end{abstract}

Desse modo, a tarefa do genealogista é promover um corte entre uma suposta relação determinista entre a coisa e a palavra que a nomeia, problematizando as relações de saberpoder que produziram realidades, saberes e subjetividades, um modo de ser, de sentir e de pensar (FOUCAULT, 2003b). As relações de poder não poderiam funcionar se não estivessem ancoradas em regimes de verdade; se não fossem imanentes à produção, à acumulação, à circulação e ao funcionamento de um dispositivo e de um discurso. Não há possibilidade de exercício do poder sem certa economia dos discursos de verdade que funcione dentro e a partir dessa dupla exigência. Somos submetidos pelo poder à produção da verdade e só podemos exercê-lo por meio da produção da verdade (FOUCAULT, 1977). Essencialmente, o objetivo nesta tese, ao fazer uma genealogia das políticas de assistência social e de saúde mental para um estudo de conteúdo de ambas, é investigar quais foram as 
forças engendradas pelas respostas públicas e estatais para transformar a assistência social em direito de seguridade social e, por outro lado, suportar a desinstitucionalização depois do desmonte do modelo manicomial no país, a partir de 2000, e como tais forças seriam capazes de atender as pessoas em medida de segurança.

Para colocar a pergunta em outros termos: como a desinstitucionalização, do lado da saúde mental, e a garantia das necessidades básicas, do lado da política de assistência social, encontraram-se e emaranharam-se com o ainda frágil papel do Estado brasileiro para assumir tais responsabilidades, tornando possíveis as mudanças de paradigma dessas políticas, embora dentro dos limites das razões de Estado, isto é, da governamentalidade de nosso Estado? A partir dos anos 2000, a política de saúde mental e a política de assistência social passaram, com o olhar no futuro, a relacionar-se com a perspectiva de cidadania, vinculando-se, no novo momento histórico, ao arcabouço jurídico do Estado democrático de direito. No entanto, com os pés no passado, as duas políticas promoveram revoluções conservadoras para levar adiante esse novo giro de perspectiva em direção ao objetivo de se vincularem à promoção da cidadania. Porque, dependendo da frágil governamentalidade assumida pelo Estado brasileiro a partir dos anos 2000, romper com as amarras do passado depende do jogo de forças cotidiano no interior das políticas públicas e na sua relação com as demais instituições e práticas sociais, que possuem anseios díspares a respeito do papel das políticas sociais. A fim de captar tais nuanças na política de saúde mental e na política de assistência social, o método genealógico pareceu oferecer interessantes subsídios para uma análise das trajetórias históricas e contemporâneas dessas duas importantes ações do Estado voltadas para as pessoas em medida de segurança na fase de desinternação.

\subsection{Análise documental e teoria fundamentada nos dados}

Os dados levantados na pesquisa foram analisados de dois modos. Em primeiro lugar, os dados relativos ao estudo censitário nacional publicado em 2012, sobre o perfil da população em medida de segurança, foram contrastados aos dados do perfil da população em medida de segurança que tem condições de desinternação, mas permanece internada indevidamente. Houve análises pontuais em períodos determinados concomitantemente à coleta de dados dos processos da VEP, para fins de teste dos dados e das análises. Mas a análise final qualitativa dos dados ocorreu somente ao final da coleta em todos os dados. Os dados relativos à trajetória das políticas de assistência social e de saúde mental foram 
analisados em uma matriz de direitos de cidadania e direitos humanos, à luz das técnicas de análise de conteúdo de política pública (DAGNINO, 2000). No momento da análise dos dados, foi utilizada a técnica da teoria fundamentada, cujas etapas de sistematização foram: leitura integral dos dados; análise dos dados dos processos analisados; registro em formulário dos dados fechados; microanálise dos dados abertos; contração dos dados abertos; codificação; vocabulário controlado; classificação; sistematização e análise (STRAUSS; CORBIN, 2008).

O levantamento dos dados somente teve início após a validação do instrumento pela etapa de pré-teste. Dessa forma, as análises concomitantes ao trabalho de campo ocorreram depois do pré-teste, uma vez que a análise dos dados favorecer a recuperação das evidências em etapas subsequentes. As informações resultantes da análise dos dados do estudo censitário de 2011, dos processos de medidas de segurança em fase de desinternação da VEP e das políticas de saúde mental e de assistência social foram lidas e analisadas na íntegra.

A ficha de registro de informação (Apêndice A) elaborada para realizar a análise documental dos processos da VEP era composta de 30 quesitos a serem recuperados nos processos: número do processo, comarca do processo, cidade/estado de nascimento, data de nascimento, cor/raça, conjugalidade, profissão, diagnóstico, local de moradia, crime, data do crime, data da prisão, crime contra a família, grau de parentesco com a vítima, data da sentença, período da internação determinado na sentença, data da internação, quantidade de exames de cessação de periculosidade realizados, data da cessação da periculosidade, data da sentença de desinternação, local de moradia durante a desinternação, ocorrência de trabalho articulado entre a equipe da VEP e rede socioassistencial e de saúde mental, acesso a benefícios de transferência de renda, reinternação, tipos de acompanhamento de saúde durante a internação e data da extinção da medida de segurança. Essas informações sobre o itinerário de desinternação foram recuperadas por meio de perguntas fechadas e abertas e pré-definidas para analisar os dados dos processos. Foi realizada uma fase de pré-teste com três processos para aperfeiçoamento da ficha de registro de informações. Após a fase de pré-teste, o instrumento foi finalizado e deu-se início ao levantamento de dados.

$\mathrm{Na}$ etapa de análise dos dados do tipo qualitativo, fez-se uso da teoria fundamentada (STRAUSS; CORBIN, 2008). Por teoria fundamentada entende-se a técnica ancorada na formulação de teoria a partir dos dados levantados no estudo. Como salienta David Gray (2012), a abordagem de estudo de caso também pode gerar dados que ajudem a desenvolver teoria, já que esta tese conta com a metodologia de um estudo de caso para levantamento 
parcial dos dados a serem analisados utilizando a técnica da teoria fundamentada. Nesse método qualitativo, coleta de dados, análise e teoria mantêm uma completa conjugação que deve estruturar as fases da pesquisa, desde o desenho do instrumento até o momento final da apresentação dos resultados (STRAUSS; CORBIN, 2008).

Entre os tipos possíveis de análise dos dados para a formulação da teoria fundamentada, foi feita a microanálise dos dados. O procedimento da microanálise é uma proposta da teoria fundamentada para uma estratégia inicial de aproximação e apropriação dos dados pelo pesquisador. Ou seja, a microanálise é um tipo de análise detalhada dos dados linha por linha, frase por frase ou trecho por trecho dos documentos analisados, necessária no começo de qualquer estudo a fim de gerar categorias iniciais e, sobretudo, sugerir relações entre as categorias (STRAUSS; CORBIN, 2008).

Há críticas sobre as técnicas da pesquisa qualitativa que tentam desqualificá-la pela facilidade em favorecer que as percepções do pesquisador se sobreponham ao que os dados sugerem (CHARMAZ, 2009). No procedimento da microanálise, a centralidade assumida pelos dados permite que eles provoquem os pressupostos teóricos do pesquisador (STRAUSS; CORBIN, 2008). Nesse sentido, o processo de codificação surge como um modo de focar a análise dos dados naquilo que também emerge inesperadamente da empiria. No momento da microanálise, perguntas gerais e perguntas específicas guiaram o processo de análise. Ao fazer a análise microscópica, os fatos, as ações e os resultados foram conceituados e classificados com base em suas relações.

Esse é um tipo de abstração, redução e relação entre os dados que permite a diferença entre codificação teórica e codificação descritiva (CHARMAZ, 2009; STRAUSS; CORBIN, 2008). A codificação dos dados seguiu dois procedimentos essenciais: a análise foi guiada fazendo perguntas aos dados e também fazendo comparações entre eles (STRAUSS; CORBIN, 2008). As perguntas aos dados são do tipo sensíveis, permitindo uma sintonia entre o analista e aquilo que os dados indicam; teóricas, para favorecer que a codificação dos dados evidencie o processo, bem como a variação e conexão entre eles; práticas ou estruturais, para consolidar a direção da amostragem no desenvolvimento da estrutura da teoria resultante; e orientadoras, para guiar as análises dos documentos (STRAUSS; CORBIN, 2008). Além do guia de perguntas aos dados, foram feitas comparações teóricas entre eles, permitindo não só a comparação incidente entre os dados para classificá-los, mas também comparações teóricas para estimular a análise sobre propriedades e dimensões da amostragem dos dados qualitativos. 
Após a codificação dos dados, eles foram agrupados segundo suas propriedades evidentes, em outras palavras, conforme as similaridades e diferenças apresentadas em suas relações (CHARMAZ, 2009; STRAUSS; CORBIN, 2008). Essa fase de classificação permite não apenas a codificação de fatos, ações e resultados em um modo descritivo, mas também a incidência dos resultados dimensionalmente a partir da identificação e inter-relação das propriedades dos dados. Propriedades são características ou atributos, sejam eles gerais ou específicos, dos dados. Por sua vez, dimensões representam a localização de uma propriedade ao longo de uma linha ou de uma faixa de dados agrupados (STRAUSS; CORBIN, 2008). Essas categorias são importantes para guiar a seleção dos dados, ou seja, definir quais foram centrais e quais foram considerados periféricos.

O projeto de pesquisa que fundamentou esta tese foi submetido a um Comitê de Ética em Pesquisa (CEP) da Universidade de Brasília. Os cuidados éticos requeridos para pesquisas com seres humanos foram tomados durante todas as fases do estudo, seguindo todas as recomendações do CEP. As normas estipuladas pelo Conselho Nacional de Saúde, por meio da Resolução 196, de 1996, foram atendidas tanto na elaboração do projeto quanto na execução das fases de levantamento e análise dos dados. Ao CEP, foi solicitada dispensa do Termo de Consentimento Livre e Esclarecido, em razão de grande parte do levantamento de dados se tratar de análise documental. Será mantido o anonimato de todos os sujeitos da pesquisa envolvidos em todas as fases do estudo, e de forma alguma serão divulgados dados que firam a confidencialidade de quaisquer informações pessoais. 


\section{FAMILISMO NA ASSISTÊNCIA SOCIAL: UMA GENEALOGIA DAS CONTRADIÇÕES DA ASSISTÊNCIA COMO POLÍTICA DE SEGURIDADE SOCIAL}

Em 1988, a assistência social passou a integrar a política de seguridade social no Brasil. Como direito a quem dela necessitasse e responsabilidade do Estado, a assistência social representou um importante mecanismo de combate às desigualdades e privações sociais a partir dos anos 1990. De legislações infraconstitucionais capazes de oferecer suporte à materialização do direito social a uma série de novos equipamentos públicos para ofertar serviços sociais, a assistência social passou a estabelecer uma aproximação entre as ações públicas e as demandas históricas por proteção social. Com um processo iniciado no período da Constituinte da década de 1980, para atender aos anseios da sociedade em torno das atribuições dos governos na mitigação das desigualdades, a centralidade da assistência como ação pública, racional e legal criou condições para que as situações de desigualdade social não significassem automaticamente diminuição da capacidade dos cidadãos de experimentar liberdade, igualdade e autonomia. A partir dos anos 2000, os impactos da política de assistência sobre a situação da pobreza e das privações começaram a ficar mais evidentes (MEDEIROS; BRITTO; SOARES, 2007; VAITSMAN; ANDRADE; FARIAS, 2009).

Foi lento o processo pelo qual a assistência social deixou de ser meramente uma ação espontânea da sociedade, por meio da filantropia e da caridade, para se transformar em uma política pública de responsabilidade do Estado (BOSCHETTI, 2006). Esse lento processo tampouco se vê, nos dias de hoje, totalmente desligado dos fatores e das características históricas que o determinaram. A assistência social como política pública ainda convive com um universo de ações esparsas ligadas à caridade e a iniciativas privadas, individuais ou coletivas, que tornam tênues os limites entre a exclusividade pública e a possibilidade da iniciativa espontânea da sociedade civil. Talvez a convivência paralela entre esses dois mundos da assistência nem teria como deixar de existir até aqui, nem terá no futuro. No entanto, o rompimento com o legado do passado da assistência não diz respeito apenas ao universo das iniciativas espontâneas de caridade da sociedade civil. O modo como políticas de bem-estar podem ser oferecidas pelo mercado e o grau de participação de terceiros na oferta de serviços e benefícios ligados à assistência social podem representar limites à configuração da assistência como direito de seguridade e responsabilidade pública por meio de ações estatais. 
No caso da participação do mercado na oferta de serviços de bem-estar social, o modo como o Estado se retrai ao abrir espaço para a busca individual no mercado de serviços sociais pode significar o fenômeno que Esping-Andersen (1991, 2000) denomina de mercadorização das políticas de bem-estar social. Isto é, o grau de participação dos governos como incentivadores e responsáveis por materializar ações de serviços e políticas voltadas à promoção do bem-estar social aos cidadãos pode deixá-los dependentes de suas condições em pagar por tais serviços quando o Estado não enseja a desmercadorização da oferta de produtos e bens que promovem o bem-estar social (ESPING-ANDERSEN, 1991, 2000). As funções dos governos são transferidas aos mercados, que passam a ter o monopólio ou a centralidade na oferta dos serviços e programas. Consequentemente, a limitação do acesso intensifica os níveis de desigualdade e acentua as situações de privação quando os cidadãos não dispõem de meios para financiar serviços e programas privados de bem-estar social.

Semelhantemente ao processo de mercadorização dos serviços e das políticas de bemestar social quando o Estado transfere aos mercados a responsabilidade em materializá-los, o papel das famílias pode ser preponderante quando há retração dos governos na responsabilidade de ofertar políticas sociais. Familiarização ou familismo é o processo pelo qual a configuração da oferta de bem-estar social tem ampla participação das famílias, ao passo que o papel dos Estados é diminuído (ESPING-ANDERSEN, 1991, 2000). Descrever o grau de mercadorização ou de familiarização das políticas de bem-estar social é trabalho inócuo nas ciências sociais se não estiver vinculado às investigações capazes de explicar os aspectos que tornaram possíveis tais configurações. A literatura comparativa sobre a análise contemporânea dos Estados de bem-estar social encontra em Esping-Andersen lições imprescindíveis para o estudo da configuração das políticas sociais em qualquer país. No entanto, tais lições precisam caminhar ao lado de investigações que consigam elucidar os fenômenos por trás daquilo capaz de promover a desmercadorização ou desfamiliarização das políticas sociais em um ambiente específico.

O imperativo ético e de justiça social no combate às privações sociais, de alguma forma, sempre esteve presente nos debates públicos no Brasil, pelo menos, a partir da virada do regime imperial para o governo republicano em fins do século XIX (BOSI, 1996). Dessa forma, durante quase todo o século XX, combater as privações esteve sob os desígnios da filantropia e da caridade, em que o Estado tinha papel meramente figurativo, quase inexistente. Somente a partir de 2004 as ações, os benefícios e os programas que compõem a Política Nacional de Assistência Social (PNAS) assumiram características completamente 
distintas em relação ao que era praticado no país até então. A regulamentação tardia da assistência social como política de seguridade social estabelecida na Constituição Federal de 1988 e na Lei Orgânica da Assistência Social, de 1993, fez com que ela fosse reflexo das dificuldades dos governos em assumir sua responsabilidade na materialização da assistência como política social que garante direitos fundamentais (BOSCHETTI, 2006; BRASIL, 1993; TAVARES, 2008). Por outro lado, a mudança de ação, partindo de um conjunto desestruturado e desarticulado de ações esparsas para uma política unificada sob a responsabilidade do Estado, não foi capaz de romper com todas as amarras do passado naquilo que definia e caracterizava as ações de assistência social como limitadas e emaranhadas nas ações amplas de iniciativa espontânea da sociedade por meio da caridade e filantropia.

O objetivo deste capítulo é o de recuperar historicamente a constituição da política de assistência social, buscando os traços de familismo nessa trajetória. Ao percorrer a genealogia do familismo na política de assistência social, busca-se demonstrar que o presente da assistência não recepciona todas as rupturas com o passado da prática secular da caridade e filantropia no país que circunscrevia as ações coletivas de assistência. O argumento a ser sustentado no capítulo é o de que o processo de amadurecimento da política de assistência social como direito de seguridade social, a partir de 1988, só foi possível porque a responsabilidade de provisão social aos cidadãos foi compartilhada entre o Estado e as famílias. A ruptura da assistência social como prática de caridade ocorreu, embora os laços com forças e determinantes do passado ainda possam persistir. Em oposição ao que comumente se advoga sobre os avanços da estatização da assistência social a partir dos anos 1990 e, de forma mais incisiva, nos anos 2000, será investigado o quanto esse processo de tecnicidade e de profissionalização pública da assistência social, como parte da governamentalidade do Estado brasileiro, se deu porque tal atribuição foi legal, política e publicamente repartida com as famílias em níveis de transferência para as famílias, compartilhamento de responsabilidade com as famílias e omissão do Estado a depender dos programas, dos benefícios e das ações da política de assistência social.

\subsection{Entre o discurso das necessidades e a promoção da autonomia: qual o papel da assistência social?}

Antes de iniciar uma análise da relação das famílias com a prática dos governos em oferecer serviços de assistência social, é importante situar o debate da natureza da assistência 
social como política pública. Em sociedades democráticas contemporâneas, há pouca ou nenhuma discordância sobre a responsabilidade dos Estados em prevenir e combater as privações sociais indesejadas que as pessoas possam experimentar. As situações de privação social podem variar em causas, consequências e duração, entre outras características, tendo impacto sobre a capacidade das pessoas para desfrutarem da liberdade e também do desenvolvimento socioeconômico de seu país (SEN, 2000, 2001). A renda comprometida de uma família com cinco filhos jovens, cujo provedor negro e analfabeto está desempregado há dois anos; uma mãe pobre e sem ensino superior que abandonou o emprego para cuidar do filho com leucemia; um aposentado de 60 anos com diagnóstico de esquizofrenia que agride fisicamente os familiares em razão do transtorno mental; uma adolescente com deficiência física com dificuldades no desempenho escolar e uma mulher de meia-idade sem profissão que sofre violência sexual há dez anos do marido de quem ela quer se divorciar são exemplos de que as pessoas podem vivenciar graus variados de privação social, pois são eventos que impactam a autonomia na tomada de decisão e estão muito além do controle de cada um (SEN, 2000, 2001). São essas situações que, embora diferenciadas em termos de privação implicam níveis semelhantes de desigualdade e opressão experimentadas pelas pessoas, que o Estado deve atender por meio de políticas públicas e sociais.

As respostas para prevenir e combater as situações de privação social semelhantes às citadas acima podem não ser simples. Elas não são necessariamente situações a serem enfrentadas pela política de previdência social, saúde, política de trabalho e educação. Há algo de suas vulnerabilidades que remete à necessidade de uma política de assistência social, com ações que promovam o apoio para proteção da autonomia de cada um ao garantir satisfação das necessidades às pessoas. Embora muitas vezes haja apelo incontroverso pela intervenção do Estado nessas situações, as alternativas por meio de políticas públicas e sociais variam em princípios, objetividade e eficácia bem como em especificidade de cada política para proteger as pessoas das situações de privação. São muitos os exemplos em que uma combinação de princípios políticos plurais com valores da social-democracia, ambos com valorização de padrões de bem-estar social, aplicados às ações dos Estados, busca oferecer, em muitos países, respostas para que as situações de privação social não signifiquem comprometimentos mais efetivos do direito à igualdade e ao desfrute da liberdade pelas pessoas (CASTEL, 2005; ESPING-ANDERSEN, 1991; HERRERA, 2008). A assistência social está no rol de tais políticas e guarda uma especificidade diante das situações de privação social. 
No Brasil, a atuação do Estado perante as demandas sociais só foi adquirir mais objetividade e controle por parte dos governos a partir dos anos 1930, o que, somado ao processo tardio de urbanização e industrialização e a poucos períodos de continuidade democrática, fez emergir um quadro de graves desigualdades e vulnerabilidades sociais que permanecem latentes ainda hoje (BOSI, 1996; BUCCI, 2006; DRAIBE; AURELIANO, 1989; SANTOS, 1979). No caso do atendimento das necessidades básicas como garantia de um mínimo existencial a todas as pessoas, o país só foi encontrar respostas mais articuladas sob responsabilidade do Estado com a Constituição Federal de 1988 (BOSCHETTI, 2006; LEIVAS, 2008; TAVARES, 2008), quando esta transformou a assistência social em direito social que promove a garantia das necessidades básicas àqueles que a ela recorrerem.

A história da assistência social no Brasil, a partir de 1988, passou a ser orientada pelo princípio do atendimento às necessidades básicas como garantia dos mínimos sociais sob responsabilidade do Estado (PEREIRA, 2000; REIS; PESTANO, 2006). Afirmada como direito de seguridade social e efetivada por meio de uma rede de políticas públicas e sociais, a assistência social se corporificou em uma das principais estratégias de combate à pobreza e às desigualdades sociais no país nos últimos vinte anos (MEDEIROS; BRITTO; SOARES, 2007; VAITSMAN; ANDRADE; FARIAS, 2009). No entanto, ela não é apenas destinada aos estratos mais pobres da população. Existem situações de privações sociais ligadas às experiências de infância, velhice, gênero, violência, deficiência, doenças e doença mental, por exemplo, independentemente do nível de renda, que reduzem a autonomia das pessoas na tomada de decisões.

Essas situações ganharam contornos mais significativos na esfera das desigualdades sociais nos últimos anos e passaram a ser compreendidas como temas necessários de cobertura da assistência social (BRASIL, 2004b). Se o direito à assistência social não é apenas uma garantia de proteção das pessoas em situação de pobreza, é necessário compreendê-lo em uma conceituação e especificidade capaz de revelar seus objetivos, sua natureza e suas propriedades. As situações de vulnerabilidade e privações sociais revelam que as pessoas têm o direito de fazer uso da assistência, assim como preconizado na Constituição de 1988. É comum descrever que a importância moral e ética dos objetivos da assistência social reside em seu caráter de política de seguridade responsável pela provisão das necessidades básicas (BRASIL, 1993; PEREIRA, 1996, 2006b). Entretanto, ao definir a assistência social nesses termos, é possível que haja deslocamento do enfoque em torno de seus objetivos como meios e como finalidade. 
Isto é, o dever do Estado diante da assistência social implica que necessidades básicas devem ser garantidas a todas as pessoas independentemente de contribuições prévias ao sistema de seguridade social, numa orientação do papel do Estado como promotor da justiça distributiva e da garantia do bem-estar social aos cidadãos (DRAIBE; AURELIANO, 1989; FLEISCHACKER, 2006; NUSSBAUM, 2006). No entanto, o atendimento de necessidades básicas deve significar a garantia de bens, recursos e estratégias amparadas por políticas públicas e sociais que funcionam como meios para alcançar outros fins sociais (SEN, 2001). Nesse sentido, o atendimento das necessidades básicas não se encerra em si mesmo, ao prover carências materiais ou recursos sociais básicos, mas deve ser um meio transitório para outras finalidades sociais que promovam a igualdade, a liberdade e a proteção à dignidade humana.

As privações sociais experimentadas pelas pessoas que suscitam o imperativo do atendimento das necessidades básicas geralmente estão relacionadas a outras características individuais e sociais que impedem uma vida com liberdade e autonomia. Por exemplo, não é apenas em razão da pobreza que as pessoas não acessam bens sociais e materiais, ficam desempregadas ou ainda se alimentam de maneira insuficiente, situações de privação que gerariam a necessidade de uma política de transferência direta de renda (SEN, 2001). Independentemente do nível de renda, as pessoas têm diminuídas as condições efetivas de viver uma vida com liberdade e bem-estar em decorrência de doenças, deficiência, baixo nível de escolaridade ou moradia em regiões que oferecem poucas oportunidades no mercado de trabalho. É a partir dessas considerações que os objetivos da assistência social não podem ser compreendidos como de atendimento finalístico às necessidades básicas para combater as privações materiais e sociais; há muitas situações de privação em que o atendimento às necessidades básicas se mostra insuficiente para a proteção da autonomia das pessoas e seu consequente desfrute da liberdade.

Além disso, ao mesmo tempo em que uma rede de proteção social se efetivou no Brasil nos últimos vinte anos, com o objetivo de estruturar a política de assistência social, esse direito de seguridade social tem sido cada vez mais compreendido como aquele que protege as pessoas que não fazem parte da sociedade produtiva por algum motivo de inabilidade ao trabalho, como pessoas com deficiência ou alguma doença, idosos, adolescentes, crianças e desempregados (SANTOS, 2006, 2008, 2010; SOARES, 2006). Essa compreensão restrita da assistência é incompatível com os princípios constitucionais que embasam o direito individual à assistência social, embora encontre apoio nas diretrizes orientadoras da política social assinaladas na LOAS, aprovada em 1993 (PENALVA; DINIZ; 
MEDEIROS, 2010). Definir as pessoas que devem ser atendidas pela assistência social como aquelas que, por alguma razão, estão ou são desprovidas da capacidade para o trabalho traz duas consequências. Primeiro, dificulta o atendimento das necessidades básicas a todos que delas precisam, já que não é somente a incapacidade para o trabalho que gera a obrigação desse atendimento. Em segundo lugar, impede que a seguridade social seja estruturada tendo a proteção à dignidade humana, à cidadania ou à autonomia como princípios constitucionais orientadores do direito social ao priorizar os valores sociais do trabalho para orientar a política de assistência social.

Ao compreender a assistência como política de proteção social para aquelas situações resultantes além dos motivos da pobreza e da incapacidade para o trabalho, é necessário buscar os princípios básicos capazes de sustentar politicamente o objetivo e a especificidade desse direito (REIS; PESTANO, 2006). As bases fundamentais do Estado democrático brasileiro estão presentes na Constituição Federal de 1988, o que indica que os fundamentos para uma especificação dos objetivos da assistência social se encontram na carta constitucional. Desse modo, a dignidade humana constitui um dos princípios basilares do Estado em tratar cada indivíduo como detentor do igual direito à liberdade, ou seja, o valor moral da dignidade exige que cada pessoa seja tratada como um fim em si mesmo e não como um meio para o fim de outro alguém. ${ }^{4}$ A dignidade humana está relacionada com um conjunto de elementos para que uma pessoa consiga ser e fazer tudo aquilo que importa para uma vida plena do ponto de vista ético, desenvolvendo as capacidades humanas que endossam um ideal de vida boa para essa pessoa (NUSSBAUM, 2006). Embora central para o direito da assistência social, o princípio da dignidade humana pouco esteve presente como fundamento na regulamentação da política de assistência social na LOAS, em 1993, cinco anos após a proclamação da constituição.

A assistência social é uma proteção à possibilidade de exercício da autonomia dos indivíduos. É uma resposta a situações de privação social decorrentes de infortúnios incontroláveis pelos sujeitos que reduzem sua autonomia. Em uma sociedade demarcada pelos

\footnotetext{
${ }^{4}$ Martha Nussbaum (2006) concebe uma noção de dignidade humana aristotélica-marxista que se aproxima das concepções aqui defendidas. Nussbaum (2006) elabora uma concepção de dignidade humana a partir das ideias inspiradas por Aristóteles a respeito da condição do ser humano como animal político, ao mesmo tempo em que se inspira nas ideias de Karl Marx que concebe o ser humano enquanto ser social que se realiza por necessitar de um conjunto variado de necessidades vitais. Essa concepção de dignidade humana pode servir como inspiração para as ações do Estado que devem tratar os indivíduos como fins em si mesmos na medida em que consegue prover as condições necessárias aos indivíduos para o desfrute deles dessa noção de dignidade humana. A utilização do conceito de dignidade humana aqui, não busca reafirmar idealismos, apenas tem a pretensão de demarcar atribuições importantes dos governos ao implementar políticas sociais para a promoção dessa noção de dignidade humana.
} 
valores do trabalho produtivo, tem-se a expectativa de que a autonomia dos sujeitos decorra da vinculação a essa sociedade produtiva, e o mundo do trabalho funciona como uma proteção social automática aos indivíduos pertencentes a esse mundo, como ocorreu no Brasil até os anos 1980 (SANTOS, 1979). No entanto, as privações sociais não resultam unicamente das inadequações dos sujeitos desprovidos da capacidade laboral em uma sociedade estruturada em torno do trabalho. Há situações de privação material e social, inclusive, para aqueles que fazem parte do mundo do trabalho. Na medida em que os infortúnios se localizam em causas que ultrapassam a questão social introduzida pelo capitalismo, as respostas para enfrentá-los têm de ser complexas. Não significa que o capitalismo não tenha intensificado ou criado novas situações de infortúnios que levam a privações sociais e que a assistência social não tenha que ser sensível a esse cenário.

\subsubsection{Assistência como proteção da dignidade: lampejos iluministas em práticas tradicionais}

Do ponto de vista jurídico, os objetivos da assistência social a serem materializados no Brasil a partir dos anos 1990 têm relação com os princípios estabelecidos no texto constitucional de 1988 (TAVARES, 2008). Do ponto de vista político, têm a ver com os direcionamentos a serem dados para a formulação de respostas estatais e governamentais para a superação de situações de vulnerabilidade e privação social, cujas origens são diversas e fazem parte da formação sócio-histórica, política e cultural da sociedade brasileira (BUCCI, 2006; LOBO, 2008). Do ponto de vista histórico, têm a ver com o modo como uma ação secular já existente que oferece apoio a indivíduos com autonomia reduzida precisa se deslocar das iniciativas espontâneas da sociedade, por meio da caridade, para uma prerrogativa do poder público (BOSCHETTI, 2006). Esses três pilares definem os traços contemporâneos da assistência social, bem como orientam a análise sobre os pontos que representam o continuísmo com práticas passadas que podem ter impacto no perfil da política atualmente. Isto é, a assistência social é uma ação pública componente de uma doutrina política que reconhece o atendimento de necessidades básicas como um requisito essencial para a garantia de direitos fundamentais e de uma sociedade que prima pela justiça e autonomia dos cidadãos (NUSSBAUM, 2006; PEREIRA, 1996). Essa foi a principal mudança introduzida pela entrada da assistência social como componente da política de seguridade social (BOSCHETTI, 2006; TAVARES, 2008). Todavia, é preciso prestar atenção no modo como essa guinada da assistência social amparada em valores políticos específicos encontra recepção para uma eficiência na materialização de seus objetivos. 
As doutrinas políticas que reconhecem a assistência social como instrumento garantidor de direitos fundamentais partem da ideia de que as necessidades corporais, inclusive as necessidades por assistência, cuidado e apoio para a autonomia, formam parte da sociabilidade inerente à condição humana (NUSSBAUM, 2006; PEREIRA, 2006b). Ou seja, a necessidade de assistência é um aspecto da dignidade humana e não algo que vá de encontro a ela (NUSSBAUM, 2006). Uma decorrência dessa compreensão é que não se pode derivar a noção de dignidade humana e outros valores políticos fundamentais de uma sociedade apenas do fato de os indivíduos serem produtivos e independentes. Uma sociedade que valoriza a dignidade humana pressupõe que os indivíduos precisam de tais proteções básicas independentemente de serem ou não produtivos ou de contribuírem com seu trabalho para o desenvolvimento da sociedade (NUSSBAUM, 2006). Isto é, a sociedade cultiva valores e estabelece leis para o convívio compartilhado entre os indivíduos por compromissos mútuos variados, dos quais a produtividade e a capacidade para o trabalho são apenas um dos requisitos e não a finalidade principal. Essas são noções essenciais para a compreensão da assistência social como política de seguridade social que materializa direitos fundamentais.

$\mathrm{Na}$ história da justiça distributiva no mundo ocidental, nem sempre foi possível descrever a assistência social como ação pública de responsabilidade do Estado que visa à proteção da autonomia dos indivíduos (FLEISCHACKER, 2006; PEREIRA, 2008). Até mesmo ao acompanhar o desenvolvimento histórico do papel dos governos em implementar políticas públicas para combater injustiças sociais, leva-se um tempo para encontrar com a assistência social como responsabilidade governamental por meio de ações de redistribuição de bens materiais e recursos sociais. A assistência social, junto de outras ações públicas, nasce como responsabilidade dos Estados somente quando valores em torno de princípios de justiça distributiva passam a orientar os papéis dos governos em países no mundo europeu, principalmente no século XVIII, após a Revolução Francesa (FLEISCHACKER, 2006). É da mudança de atitude dos governos em relação às necessidades dos pobres que as políticas de promoção de bem-estar social ganham status diferenciado lentamente a partir do século XIX e, de forma mais incisiva, no pós-Segunda Guerra Mundial, e passam a representar, inclusive, uma espécie de métrica capaz de avaliar o quanto os países são justos (ESPING-ANDERSEN, 1991).

A presença de ações voltadas para livrar as pessoas da situação de miséria é tão antiga na Europa quanto a própria existência da pobreza. As ações coletivas de combate à pobreza antecedem até mesmo a constituição de muitos Estados Nacionais europeus, o que remete as 
inquietações com a pobreza a um passado tão remoto que aproxima a assistência mais das vocações comunitárias em cuidar de seus integrantes do que das vocações políticas dos governos (CASTEL, 1995). Isto é, para o universo da pobreza, pelo menos desde o século XIV, há ações voltadas para algum projeto incentivado pela Igreja Católica capaz de abranger um território e amenizar o sofrimento das pessoas da paróquia diante das agruras da miséria. Em 1351 na Grã-Bretanha, por exemplo, no reinado de Eduardo III, em pleno período da Peste Negra, uma medida para combater a escassez de braços para trabalhar nas fazendas deu início a uma imbricada relação entre disciplina para o trabalho, combate à pobreza e institucionalização da assistência por meio do Statute of Labourers (CASTEL, 1995; PEREIRA, 2008). Essa medida instituiu salários, abrigou os pobres e proibiu a perambulância de pessoas em busca de melhores ocupações, isto é, a chamada "vagabundagem". O teor dessa e de outras Leis dos Pobres era muito mais punitivo que protetivo (CASTEL, 1995). As práticas caritativas da Igreja Católica permaneceriam entre as ações coletivas destinadas aos pobres nos quatro séculos seguintes como principal instância de regulação da pobreza, embora o objetivo nunca tenha sido de fato varrer das terras europeias as situações de miséria.

As práticas e as instituições de caridade não visavam o combate à pobreza como uma medida de justiça. Mas, principalmente, tinham o objetivo de provocar um enquadramento nos limites dos saberes eclesiais como técnica e como discurso místico para as explicações dos fenômenos sociais ligados à miséria, à fome e às doenças (FOUCAULT, 2006). Os saberes religiosos durante a Idade Média precisavam dar ordenamento ao mundo por meio de explicações para a pobreza, ao mesmo tempo em que se oferecia um lugar aos pobres e se amenizava suas necessidades. A caridade cumpriria esse duplo papel: ao explicar a origem da pobreza como desígnio divino, as instituições de caridade pregavam a libertação dos pobres e dignificavam quem praticava a caridade por uma medida curiosa, mas eficiente, de distinção entre os cristãos ricos caridosos e os pobres sem sorte e pecadores (FLEISCHACKER, 2006). Em outras palavras, a caridade não tinha uma função somente para quem dela necessitava: ser caridoso era um importante atributo para diferenciação e prestígio no mundo dos católicos.

Apenas com o processo revolucionário francês do final do século XVIII, as doutrinas políticas e filosóficas assumiriam a ideia de que a proteção das pessoas da miséria deveria ser desenhada na perspectiva do direito a viver livre da pobreza (FLEISCHACKER, 2006). Para esse deslocamento da prática secular da caridade para um direito a viver livre da miséria, eram necessários quatro movimentos: o primeiro era o de que a responsabilidade dessa ação precisaria ser transferida da Igreja para os poderes públicos. Depois, os pobres precisariam ser 
vistos, antes de tudo, como seres humanos portadores do direito a viver em um mundo onde a pobreza fosse tida como imerecida e injustificada. O terceiro movimento era o de que combater a pobreza tinha de significar uma ação pública vinculada à ideia de dignidade humana nascida com a Revolução Francesa, isto é, uma ação de combate à pobreza precisaria estar amparada na busca pelo igual direito à liberdade, como um direito humano e como tratamento dos indivíduos como fins em si mesmos e não como meios para outros fins. $\mathrm{O}$ quarto movimento era o de que as ideias de combate à pobreza precisariam entrar no rol das defesas e lutas políticas que encampariam tal reivindicação a ser legitimada nos movimentos sociais pelo fim do Antigo Regime e por melhorias nas condições de vida dos trabalhadores e dos cidadãos de modo geral. Para Samuel Fleischacker (2006), o primeiro movimento foi provocado pelas ideias de Jean-Jacques Rousseau, o segundo movimento, por Adam Smith, o terceiro, pelas fecundas ideias de Immanuel Kant, e o quarto, pelas ideias do revolucionário francês Graco Babeuf — quatro dos principais teóricos da Revolução Francesa.

Essas fecundas ideias provavelmente estiveram por trás da concepção da Lei de Speenhamland, de 1795, na Inglaterra (PEREIRA, 2008). Essa medida inglesa distinguiu-se das demais Leis dos Pobres existentes até então por não vincular exclusivamente ao mundo do trabalho as proteções aos pobres. Isto é, pela primeira vez, uma lei promovia a garantia de mínimos de subsistência para, inclusive, trabalhadores e não mais somente os absolutamente incapazes para o trabalho. Até então, as leis dos pobres puniam severamente aqueles que, embora tivessem capacidade para o trabalho produtivo, não o faziam por algum motivo. Já as medidas de assistência estavam restritas àqueles totalmente incapazes para o trabalho, como crianças, idosos, doentes e deficientes (CASTEL, 1995). A Speenhamland Law foi, portanto, a primeira medida de assistência social que reconheceu a necessidade de intervenção pública para melhoria das condições de vida dos trabalhadores, para além das proteções que a economia de mercado poderia oferecer.

Os avanços introduzidos com essa medida no final do século XVIII durariam apenas até 1834, quando a Poor Law Amendment Act, conhecida como a Nova Lei dos Pobres, aboliu a proteção pública aos trabalhadores na extrema miséria (PEREIRA, 2008). A Nova Lei dos Pobres introduziu aspectos liberais de não intervenção do Estado na economia de mercado, que perduraria por todo o século XIX, deixando novamente a prática da assistência a cargo das instituições de caridade. No entanto, a ideia de resguardar os indivíduos da pobreza como proteção da dignidade por meio de ações públicas já tinha sido lançada no imaginário social, filosófico e político da Europa. 
Se, na Europa, a partir da Revolução Francesa, ficou evidente a ideia de que a proteção contra a pobreza significava a responsabilidade do Estado em promover o igual direito das pessoas a melhores condições socioeconômicas, nos Estados Unidos da América, em 1875, a decisão de um juiz da Suprema Corte reconheceu de forma inaugural que o "auxílio aos pobres - o cuidado que se deve dedicar àqueles que são incapazes de cuidar de si próprios está entre os objetos inquestionáveis do dever público" (FLEISCHACKER, 2006, p. 119). Já no início do século XX, Noruega, Suécia e Finlândia instituíram auxílios aos pobres como proteções mínimas, dando origem às assistências compulsórias de responsabilidade dos governos (CASTEL, 1995). Apesar disso, todas as medidas de assistência aos pobres que surgiram no final do século XIX e início do século XX destinavam-se aos incapazes de se manter, de se sustentar ou de trabalhar, até mesmo nas defesas dos revolucionários franceses (FLEISCHACKER, 2006). De modo geral, o combate à pobreza se transformou definitivamente em uma prerrogativa menos controversa no que diz respeito ao papel dos Estados. Entretanto, era a garantia de proteção aos incapazes de se manter por meio do trabalho.

Somente com a Declaração Universal dos Direitos Humanos, em 1948, foram afiançadas as proteções contra as privações materiais desvinculadas da lógica da incapacidade para o trabalho, ou seja, como direito de todas as pessoas. Pela primeira vez, em um ordenamento jurídico internacional, foram estabelecidos os direitos ao seguro social e aos bens econômicos, sociais e culturais indispensáveis à dignidade de cada pessoa e ao livre desenvolvimento de sua personalidade, além das proteções contra o desemprego e do direito a alimentação, vestuário, habitação e cuidados médicos. Paralelamente à Declaração Universal dos Direitos Humanos, ocorriam na Inglaterra medidas amplas de orientações ao papel dos governos na promoção de bem-estar social, conhecidas como o Plano Beveridge, ou modelo beveridgiano. Esse plano estabeleceu como direitos universais o acesso à saúde, à educação, a políticas previdenciárias amplas e a políticas de combate à pobreza vinculadas à lógica da cidadania (PEREIRA, 2008). Enfim, a partir de meados do século XX, ganhou força a perspectiva de combate à pobreza independentemente da participação dos indivíduos no mercado de trabalho.

No cenário brasileiro, as concepções revolucionárias a respeito do papel dos poderes públicos no combate à pobreza chegariam de forma mais incisiva ao ordenamento jurídico apenas no final do século XX (BOSCHETTI, 2006; BUCCI, 2006; TAVARES, 2008). O modo como as concepções jurídico-filosóficas se acoplariam à ideia política de que combater 
a pobreza seria uma medida de promoção da justiça social levaria anos para se desgarrar da exclusividade das práticas caritativas da Igreja Católica e das ações espontâneas da sociedade por meio da filantropia no Brasil. A presença marcante da caridade nos séculos XVII, XVIII, XIX e em boa parte do século XX, em solo brasileiro, deixaria marcas profundas no paradigma de atuação dos governos para atendimento das necessidades básicas das pessoas por meio da institucionalização da assistência como promoção de bem-estar social. A relação entre os governos e as famílias como agentes de proteção social definiria funções sobrepostas aos dois entes, mesmo quando o ordenamento jurídico teria recepcionado a ideia de combate à pobreza como prática de proteção da autonomia dos indivíduos ligada à concepção iluminista da dignidade humana. A tutela introduzida pelas práticas da caridade destinara às famílias um lugar fundamental na proteção social que, inclusive, represava o papel dos governos na medida em que as famílias ocupariam as funções de proteção social dos indivíduos mesmo com a presença de políticas públicas do Estado.

\subsection{Assistência, caridade e tutela no Brasil: a genealogia da cidadania pré-fabricada na República inacabada}

A história da assistência social no Brasil como uma ação coletiva, embora não estatal e não totalmente pública, remonta ao período colonial. Para Lilia Ferreira Lobo, a ideia de que o "Brasil era uma terra conquistada e precisava de habitantes" (2008, p. 255) incentivou a vinda de pessoas para a colonização do país, ao mesmo tempo em que expurgou os chamados vagabundos, criminosos de todas as espécies e homens brancos de má qualificação da metrópole portuguesa. Desde o início, o processo de colonização brasileiro foi demarcado pela exportação da metrópole portuguesa de homens sem posses, delinquentes e até mulheres “erradas" (ARAÚJO, 1993, p. 122) como estratégia de povoamento, fortalecimento e expansão das terras conquistadas. Por outro lado, o banimento do território do reino português servia ao ideal de limpeza, higienização e correção das cidades europeias, cujos sujeitos incômodos e perigosos, agora, desafiavam a paz da metrópole mais do que no período medieval; era preciso expurgá-los para as colônias por meio das naus dos degredados (LOBO, 2008).

Desse caldo de desgarrados e incômodos surgiu a necessidade das primeiras medidas de combate à vagabundagem, de proteção ao pauperismo e de disciplinamento ao trabalho por meio de práticas caritativas dos jesuítas no Brasil Colônia. A militância dos pertencentes à Companhia de Jesus representava a vivacidade da Igreja Católica e suas práticas por meio do 
espírito missionário de evangelização dos povos recém-chegados e dos povos indígenas já presentes em terras brasileiras (LOBO, 2008). As práticas, mais do que as palavras, davam um lugar aos condenados ao degredo (LOBO, 2008). Aos delinquentes da metrópole, aos indigentes, aos indígenas, às prostitutas, aos ciganos e até aos escravos africanos, a Companhia de Jesus destinava um lugar. Esse lugar poderia ser, e certamente era, subalternizado, mas tinha o papel de organizar esses tão diferentes grupos de expurgados e de coordenar as ações privadas de caridade no país. A orientação de ações direcionadas a esses grupos, além de ações para os doentes e deficientes, deu origem a práticas de correção e tutela que atravessariam mais de quatro séculos no Brasil. Tais ações foram capazes de determinar alguns padrões direcionados aos desclassificados, aos sem posse de todos os gêneros e aos incapazes da Colônia, do Império e da Velha República. Dessa forma, a prática da caridade seria estendida, de certo modo e com poucas diferenças, até tempos presentes.

Com o processo mais intenso de urbanização em meados do século XIX, a pobreza, que antes estava dissipada nos limites das propriedades rurais e, de certa forma, amenizada por tal represamento, foi sendo cada vez mais transformada em uma ameaça para as poucas cidades já existentes. Mesmo lento — no final do século XVIII, as cinco principais cidades abrigavam não mais que $5,7 \%$ da população do país (COSTA, 1979) —, o processo de urbanização, de repente, passou a exigir uma maior vigilância sobre os banidos do reino português, os escravos expulsos da África, os poucos ex-escravos já existentes, os índios desterrados e os pobres e rurícolas sem posses. Para estes, foi ficando clara a necessidade de ações mais específicas e direcionadas, a depender do tipo de público, individualizando ações e racionalizando, na medida do possível, práticas da administração portuguesa (LOBO, 2008). Ou seja, a organização das vilas urbanas nascentes exigia também uma organização de sua população por meio da ocupação de espaços demarcados para cada grupo.

As Santas Casas de Misericórdia ocuparam na Europa e também no território brasileiro o principal papel de amenização da pobreza, de cuidados paliativos em saúde e de prática e tratamento moral tanto para buscar a cura quanto para aliviar os necessitados da indigência. Em 1552, já existiam cerca de 12 Santas Casas de Misericórdia espalhadas pelo Brasil Colônia. Em 1584, José de Anchieta sinalizou que "em todas as Capitanias há Casas de Misericórdia, que servem de hospitais, edificados e sustentados pelos moradores da terra com muita devoção, em que se dão muitas esmolas, assim em vida como em morte, e se casam muitas órfãs, curam enfermos de toda a sorte [...]" (ARANTES, 1995, p. 194). A proliferação das Santas Casas de Misericórdia no território colonial fez ganhar peso a ideia da pobreza 
como problema a ser enfrentado, ainda que um problema mais moral do que propriamente uma injustiça social imerecida que era preciso eliminar (LOBO, 2008). Não somente, mas principalmente, as Santas Casas foram as principais instituições de caridade responsáveis por socorrer os pobres, indigentes e escravos desgarrados durante o período entre o Brasil Colônia e o início da republicanização do país, no final do século XIX.

A caridade praticada pela Igreja Católica e a filantropia de diversas associações assumiram, então, papel primordial para oferecer respostas a essa organização necessária dos grupos desordeiros e perigosos que compunham os cenários das primeiras cidades no país (LOBO, 2008). Como a explicação da natureza da pobreza estava ligada ao pecado ou ao castigo divino, cabia às instituições de caridade diferenciar entre aqueles que eram incapazes para o trabalho ou os autênticos trabalhadores indigentes e os verdadeiramente desocupados. Para responder ao temor do perigo representado pelos "vagabundos", a administração pública oferecia a punição severa. Por sua vez, a caridade abençoava e purificava os inválidos e trabalhadores indigentes; ao mesmo tempo, santificava quem praticava as ações e administrava as obras de caridade (LOBO, 2008). Essa, talvez, seja uma característica indelével do paradigma da caridade no Brasil Colônia, no Império e também no século XX, que destinava um lugar subalternizado aos desclassificados, mas, ao mesmo tempo, reforçava e dignificava com prestígio social aqueles que eram caridosos (LOBO, 2008). Certamente, uma das consequências dessa característica é de que promover a cidadania ao combater a pobreza por meio de ações de responsabilidade predominantemente governamental só seria uma ideia política razoável no final do século XX e início do XXI no país. As amarras da caridade impediram por séculos o amadurecimento da compreensão de que combater a pobreza fosse uma medida de justiça social.

O paradigma de enfrentamento à pobreza introduzido pela caridade no Brasil Colônia deixou marcas difíceis de superar nos anos seguintes. A caridade praticada pela Igreja Católica nunca descreveu a pobreza como um problema de desigualdade, e a sociedade colonial e imperial nunca questionou a pobreza como um problema social a ser combatido e eliminado em nome da justiça social. Se a caridade purificava a pobreza, assentando-a como pecado e posterior libertação divina, a sociedade colonial e imperial a denunciava como perigo à ordem das cidades e ao desenvolvimento do país. Segundo Lobo (2008), na década de 1850 uma medida foi tomada para minimizar a mendicância, separando os diversos tipos de mendigos com medidas de disciplina para o trabalho: a adaptação do Matadouro de Santa Luzia para o estabelecimento de albergues de mendigos inválidos. A partir de 1854, “a polícia 
pode encaminhá-los, então, a locais diferentes: os inválidos para o albergue, doentes para as Santas Casas, vadios válidos para a Casa de Correção e, em 1852, loucos para o Hospício de Pedro II" (LOBO, 2008, p. 328). Desse modo, o binômio tão presente no Brasil Colônia, no Império e na Velha República - caridade/libertação de almas e pobreza/perigo social introduziria, no século XX, barreiras essenciais ao desenvolvimento da ideia de que o combate à pobreza deveria ser visto como um imperativo ético e de promoção da justiça social.

Não era só a centralidade do papel moral presente na caridade que dificultava o entendimento do combate à pobreza como responsabilidade do Estado. A caridade tinha uma perspectiva comercial e lucrativa desde o início no Brasil. Na Colônia e no Império, a administração no Brasil sempre transferiu para a iniciativa privada a prática da assistência, seja aquela voltada para a saúde, seja a de combate à pobreza (LOBO, 2008). Foi assim com o repasse de recursos para as Santas Casas de Misericórdia, que ainda hoje sobrevivem por meio dessa lógica. Foi assim também com o repasse de recursos para entidades filantrópicas nos séculos XIX e XX no tocante à proteção social em casos de infância, velhice, doença e deficiência. A lógica empresarial e a busca desenfreada pelo lucro impressionam quando se observa que, em 1853, as Santas Casas de Misericórdia eram mais lucrativas e acumulavam um patrimônio equivalente a quase o dobro do patrimônio do Banco do Brasil. Já em 1882, elas detinham patrimônio superior ao capital somado de todas as indústrias metalúrgicas (LOBO, 2008). Essa característica tão marcante para a prática da assistência dificilmente seria superada nos anos subsequentes em governos republicanos e democráticos no Brasil.

3.2.1 Entre as práticas privadas, as necessidades de todos e o papel do Estado-polícia: caridade como paradigma

Ao lado do problema do controle dos perigosos, pobres desocupados e indigentes da colônia e do Brasil imperial, estava a necessidade de ordenamento das cidades, pela constituição do poder de polícia e do recrutamento para as forças militares (COSTA, 1979; MACHADO et al., 1978). A partir da segunda metade do século XVIII, o Brasil Colônia necessitava cada vez mais de braços para o ordenamento policial e a formação de uma força militar capaz de combater invasões estrangeiras que ocorriam do norte ao sul do país. Essa necessidade começou a direcionar para a população indigente, devassa e revoltosa o papel de defender as terras coloniais. Isto é, a população começou a ser alvo de práticas para o recrutamento militar e o espaço da cidade foi sendo transformado conforme os interesses de 
segurança pública da administração portuguesa (COSTA, 1979). Era preciso controlar os arruaceiros e civilizar os povos incultos para a urbanização, ao mesmo tempo em que a cidade passava a ser lugar estratégico de defesa, regeneração e constituição do poder policial e militar (LOBO, 2008). Como a cidade representava, alegadamente, o legalismo e a ordem, em oposição ao banditismo e ao perigo do interior rural, a militarização de seus moradores cumpria o duplo papel de ordenamento, por meio das práticas morais, e de aliciamento e fortalecimento da administração pública, que se legitimava perante a massa amorfa e incrédula da população indiferente às exigências das burocracias legalistas do Brasil Colônia (COSTA, 1979; MACHADO et al., 1978).

O poder policial teria duas grandes ações voltadas para a população. A primeira seria a contínua busca de indivíduos para a formação do corpo militar e policial das cidades coloniais. Não foi de uma estratégia governamental, técnica e burocrática robusta que resultou a militarização necessária para a defesa das terras da Colônia. Ela nasceu, na verdade, da cooptação da população pobre como única alternativa para formação do corpo de defesa dos interesses da sociedade colonial (COSTA, 1979; MACHADO et al., 1978). Por outro lado, na medida em que o corpo policial e militar foi formado no Brasil por meio da cooptação da população pobre, a relação da administração pública portuguesa deu os primeiros passos para um espírito peculiar de tratamento da questão social que estaria presente por séculos: o combate à pobreza, antes de ser uma questão de direito de quem experimenta a pobreza, é um problema de polícia. Entre a prática de caridade como questão moral e a prática de polícia como necessidade da administração portuguesa, a relação do Estado com a pobreza não encontrou possibilidade de ascender à temática na esfera da justiça social.

Desse modo, a tríade caridade, filantropia e polícia deu origem a um sem-número de práticas e instituições com o objetivo de destinar um lugar aos indesejáveis. Desde o início da administração pública no país, era tênue a linha que separava a higienização das cidades da punição à indigência injustificada pela vagabundagem. Essa nebulosidade fez nascer no Brasil a ideia de que a institucionalização dos necessitados nem sempre veio atrelada à prática da assistência como proteção social, mesmo que limitada (LOBO, 2008). Isto é, albergues e abrigos para pobres, instituições e orfanatos para crianças, asilos, hospitais e hospícios para velhos e loucos, internatos especiais para cegos, surdos e outros deficientes fizeram emergir no Brasil o encarceramento dos pobres. Com isso, introduziu-se um traço definitivo das respostas públicas para as agruras da pobreza: o encarceramento dos indesejáveis, de um lado, e a prática de polícia e moralização voltadas para a higienização das famílias, de outro, 
fizeram com que os governos se legitimassem como detentores de um saber/poder sobre as famílias (COSTA, 1979; MACHADO et al., 1978). Esse saber/poder influenciava, principalmente, como as famílias deveriam gerir suas vidas e a de seus membros, por meio dos saberes da medicina social, para atender às demandas do aparato militar e policial e para internalizar os valores sociais em torno do trabalho. A polícia, a higienização e a tutela do internamento, portanto, passaram a representar as bases do padrão de intervenção governamental para dissimular o universo da pobreza e criar as condições para que a urbanização e a industrialização ocorressem ao lado de um amadurecimento da administração pública na virada do século XIX para o XX.

Segundo Lobo, a cidade no Brasil, na virada do século XIX para o XX, desenvolveu novas exigências, produziu novas práticas e, ao mesmo tempo, reinventou o saber/poder da administração pública por meio de

novas disciplinas para enfrentar o urbano: a medicina social, o higienismo, a sociologia, a psicologia, a estatística, novas práticas de intervenção, - o deslocamento do olhar dos problemas específicos e pontuais para a cidade como um todo, - que não deixará de esquadrinhá-la nos mínimos detalhes, que desconfiará das multidões e das aglomerações, da proximidade, num mesmo espaço de ricos e pobres, palacetes e cortiços, patrões e operários, prostituas e desocupados. A cidade não seria mais o cenário das práticas sociais como os "dramas" da caridade dos tempos da Colônia. Ela era o próprio campo das intervenções de um saber científico, neutro, e verdadeiro, que legitimava a norma e impunha uma ordem neutralizada e universal. Campo de exercício das disciplinas, não apenas nas separações dos espaços institucionais (asilos, prisões, hospitais, fábricas, escolas), na reconstrução da arquitetura do meio urbano e de seus serviços públicos, como também no mundo privado das moradias, dos hábitos, das rotinas familiares. Formas de um poder ao mesmo tempo de controle maciço sobre as populações e individualizador das condutas, que produziria almas urbanizadas [...] (2008, p. 302).

Embora longa, a citação é importante: consegue precisar a dimensão dos desafios postos ao Brasil no processo de urbanização e industrialização a partir do século XX. A aproximação entre a administração pública e as demandas sociais produziu um conjunto de práticas e saberes que alterava profundamente o papel dos governos no enfrentamento das situações de privação social experimentadas pelos indivíduos e pelas famílias.

Por outro lado, a purificação pela pobreza que a caridade entronou por séculos desde o período medieval na Europa e que foi trazida ao Brasil pelos jesuítas deu lugar à purificação pelo trabalho num país cada vez mais urbanizado no século XX (LOBO, 2008). Isto é, houve um redirecionamento para o modo como o poder público passaria a lançar luz sobre os 
problemas sociais: não era mais a caridade que abençoava e purificava os pobres; era o trabalho que os libertava. As ações públicas no século $\mathrm{XX}$ assumiram duas grandes distinções: uma primeira, em que a proteção ao mundo do trabalho com as primeiras iniciativas de previdência social introduziu a cidadania, mesmo que limitada, no Brasil ao proteger essencialmente os trabalhadores, a partir de 1923 (SANTOS, 1979); e uma segunda, em que a assistência social se fortaleceu inicialmente como prática privada. No entanto, aos poucos, seria auxiliada pelo poder público, a partir dos anos 1940, por meio da Legião Brasileira de Assistência (LBA), em que o Estado passou a financiar iniciativas de caridade por meio de intervenção nas situações de pobreza e abandono. Embora tenha havido cada vez mais intervenção do poder público entre 1942 e 1988, o Estado exerceu papel apenas secundário na organização e expansão da assistência social como política pública até a aprovação da LOAS, em 1993.

Assim, a configuração complexa da questão social no mundo e no Brasil trouxe a denúncia do antagonismo do sistema capitalista marcado pelo pauperismo generalizado e pelos problemas sociais e de saúde dos trabalhadores e suas famílias provenientes da contradição capital/trabalho. Nesse sentido, o despertar para a questão social introduziu as lutas trabalhistas como possibilidades de ampliação das proteções sociais e melhorias nas condições de vida dos trabalhadores e de suas famílias. Situações degradantes de habitação, alimentação, renda e, sobretudo, trabalho bem como o desenvolvimento da consciência política da classe trabalhadora gerariam, no final do século XIX no mundo e apenas durante o século XX no Brasil, o início das políticas sociais (PEREIRA, 2014). No entanto, as políticas sociais como principal atribuição de concretização de direitos sociais para atender necessidades que, no sistema capitalista, constituem a força desencadeadora da conquista da cidadania e das mudanças (PEREIRA, 2014) encontrariam um conjunto de barreiras ao longo do século XX ao se emaranharem com o espírito da caridade, da filantropia e da relação entre poder público e famílias no compartilhamento de responsabilidades para proteção social dos indivíduos.

3.2.2 Da exclusividade da caridade para a proteção ao trabalho: proteção social como sinônimo de direitos trabalhistas no Brasil do século XX

Com a industrialização e urbanização mais presentes a partir das primeiras décadas do século XX, intensificou-se a necessidade de proteção social voltada para situações de privações na vida dos trabalhadores. O ordenamento para o mundo industrial e urbano 
colocou em xeque os próprios limites do trabalho como instância de melhoria das condições de vida dos trabalhadores e suas famílias. A ideia tão propalada nos anos anteriores de que o trabalho dignificava foi colocada sob suspeita na medida em que o mundo do trabalho se transformou numa das principais instâncias de degradação da vida humana. $\mathrm{O}$ cultivo de valores sociais em torno do trabalho, a própria punição e a correção da chamada vagabundagem durante quase três séculos engendraram a disciplina para o trabalho necessária para trazer os braços a serem usados na produção agrícola, na fábrica e no comércio urbano cada vez mais crescente no país. No entanto, as longas jornadas de trabalho, as péssimas condições nas fábricas, o trabalho de crianças e de idosos e mulheres em condições inadequadas, além das baixas remunerações, incitaram os trabalhadores a reivindicar melhorias. Aos poucos, a aglomeração dos operários no universo das indústrias fez crescer a força coletiva necessária à organização dos trabalhadores para canalizar as reivindicações por meio de paralisações e greves (SANTOS, 1979). Nas décadas de 1910 e 1920, um conjunto de paralisações organizadas pelos trabalhadores abalou as rígidas estruturas do mundo capitalista industrial e urbano que se estabelecia no país.

Das várias reivindicações postas durante os movimentos grevistas surgiram as primeiras iniciativas de garantias e direitos ligados ao trabalho (SANTOS, 1979). Segundo Wanderley Guilherme dos Santos (1979), a proteção aos acidentes de trabalho, a garantia de pensões e aposentadorias em algumas empresas, a redução na jornada de trabalho e a proibição do trabalho infantil, entre outras medidas, moldaram as primeiras iniciativas de proteção social no Brasil. Embora limitadas ao mundo do trabalho, essas primeiras políticas sociais conseguiram reorientar o papel dos governos para afiançar políticas públicas voltadas para a melhoria das condições de vida das famílias. Com a promulgação da Lei Eloy Chaves, em 1923, apareceram as primeiras iniciativas legais de organização de uma rede de previdência social para os trabalhadores, as Caixas de Aposentadorias e Pensões (CAPs), a cargo das empresas (BOSCHETTI, 2006; SANTOS, 1979). As CAPs se transformavam nas medidas embrionárias para proteções ao mundo do trabalho e viriam a se materializar no sistema previdenciário brasileiro ao longo do século $\mathrm{XX}$.

As primeiras medidas de proteção ao mundo do trabalho cumpriram o papel de amenização das situações degradantes dos trabalhadores no complexo industrial-urbano nascente no Brasil nas primeiras décadas do século XX (SANTOS, 1979). No entanto, a regulação das situações ligadas ao mundo do trabalho e a consequente proteção a determinadas privações e injustiças a que os trabalhadores estavam submetidos tinha uma 
vinculação também com os objetivos da administração pública na mudança que se esperava do papel do Estado brasileiro diante das demandas por intervenção surgidas com o advento do século XX (BOSI, 1996). Os experimentos republicanos na virada do século XIX para o XX e o sem-número de medidas adotadas na administração pública após a Proclamação da República no Brasil, em 1889, não deram conta do déficit em relação à modernização do aparelho do Estado e da burocracia necessária para corresponder ao dinamismo do processo de urbanização e industrialização brasileiro.

Para Alfredo Bosi (1996), as reivindicações por melhorias nas condições de trabalho e a necessidade de modernização do aparelho do Estado resultariam numa dinâmica própria para a formação de um Estado-Providência completamente vinculado ao mundo do trabalho, em que se dependia da intervenção estatal para direcionar os rumos do desenvolvimento econômico e social do país. Embora com atraso em relação aos demais países do mundo em termos de industrialização e modernização da economia, no Brasil, essa dinâmica na interrelação entre proteção ao mundo do trabalho, modernização do aparelho estatal e intervenção maciça do Estado na economia para estimular a produção impactaria de forma decisiva o sistema de proteção social erguido ao longo do século XX.

No ensaio A arqueologia do Estado-Providência: sobre um enxerto de ideias de longa duração, Bosi (1996) analisa o modo como o desenvolvimento técnico e econômico brasileiro nas primeiras décadas do século $\mathrm{XX}$, no que tange à modernização do Estado centralizador, foi influenciado por ideias positivistas de Augusto Comte presentes nos partidos políticos republicanos - principalmente com a Revolução de 1930, que promoveu a chegada de Getúlio Vargas, do Partido Republicano Rio-Grandense, ao cargo de presidente da República. Para Bosi (1996), o grupo político capitaneado por Vargas interferiu no processo de acumulação da burguesia nascente no Brasil. Essa interferência, ao lançar mão do binômio tributação/isenção, serviu para o processo de socialização dos serviços públicos no país de modo a articular a modernização do aparelho do Estado com o tratamento dado à questão social, ou seja, ao atendimento das demandas da classe operária com a finalidade de incorporar os trabalhadores às benesses da sociedade moderna.

Dessa diretriz, surgiu um padrão histórico de formulação de políticas públicas no Brasil: as formulações pioneiras de ações para materializar garantias sociais e trabalhistas fizeram com que os indivíduos fossem concebidos antes como objetos de regulação estatal do que como sujeitos de direitos (BOSI, 1996; SANTOS, 1979). Nada muito original se comparado com o padrão de atuação da administração portuguesa, que cooptou a população 
pobre para a formação da força militar no Brasil no período colonial. Como consequência, essa dinâmica delineou concepções frágeis acerca da dignidade e da liberdade individuais como objetos de proteção na arquitetura do Estado de bem-estar social no Brasil. Alimentadas da disputa entre as oligarquias agrárias enfraquecidas e do referencial do positivismo social, as políticas públicas no Brasil caracterizaram-se pela centralidade da figura do trabalhador como cidadão tutelado, criando um ambiente de progresso econômico e social hostil aos princípios da dignidade, da autonomia e das liberdades individuais (BOSI, 1996; RIOS; SANTOS, 2008). Desse modo, a proteção social no Brasil materializou-se de forma limitada aos trabalhadores, que passaram a ter acesso a benefícios e direitos previdenciários ao fazerem parte do mercado formal de trabalho, com exceção de seus dependentes, que também ganharam acesso a serviços e assistência em saúde. Ao mesmo tempo, os trabalhadores protegidos legitimaram e deram a base de sustentação do governo getulista para se manter por 15 anos no poder.

O Estado modernizou-se com uma economia dinâmica para além da cafeicultura e da pecuária, que encontraram em Getúlio Vargas um representante à altura desse dinamismo. Também os trabalhadores da cidade e das indústrias se viam representados politicamente por ele. No entanto, a articulação entre desenvolvimento econômico e social por meio de medidas de redução das desigualdades sociais ficou limitada a um sistema de proteção social exclusivo ao universo dos trabalhadores. Das amarras dessa cobertura limitada é que a assistência social teria de se livrar, no final do século XX, para compor a concepção de seguridade social necessária à formação de um Estado-Providência ou Estado Social que tivesse como principal objetivo o alcance da justiça social para todos os cidadãos e cidadãs.

Em 1907, a população do Brasil era de 20 milhões de pessoas e havia 3.258 indústrias, com uma população de trabalhadores por volta de 150.841 (SANTOS, 1979). Treze anos depois, em 1920, a população brasileira passava dos 30 milhões de habitantes. Por sua vez, os estabelecimentos industriais tinham atingido a marca de 13.336 indústrias e o total de trabalhadores chegou a 275.512 (SANTOS, 1979). Em 1940, $42 \%$ da População Economicamente Ativa (PEA) era assalariada e 30\% da PEA não tinha registro formal de trabalho, ao passo que o desemprego atingia por volta de 7\% da população (SILVA, 2011). No que diz respeito à cobertura previdenciária, em 1960, 23\% da PEA era formada por segurados da previdência social, o que correspondia a 7,4\% dos trabalhadores, com seus respectivos dependentes, que faziam uso de proteções previdenciárias (SILVA, 2011). Esses números revelam que, embora avançada em termos de princípios, a cobertura previdenciária 
era limitada. Além disso, como a previdência social tinha limites na cobertura da população total do país, havia um quadro alarmante de desproteções, privações materiais e vulnerabilidades sociais na vida da maioria da população, que não recebia nenhum tipo de proteção previdenciária nem tinha acesso aos serviços de saúde se não estivesse trabalhando.

A assistência médica era reservada aos contribuintes das CAPs e dos Institutos de Aposentadorias e Pensões (IAPs), a partir de 1933, que eram organizados por categorias profissionais e com manutenção de responsabilidade do Estado (SANTOS, 1979). O acesso à assistência médica era condicionado à contribuição direta dos trabalhadores. Mas essa característica não lhe conferia o caráter de seguro social, uma vez que não significava o repasse de um benefício previdenciário em espécie. Desse modo, assistência médica era considerado assistência social no universo das proteções aos trabalhadores (BOSCHETTI, 2006). Isto é, o que se compreendia como assistência social como prestação aos trabalhadores era um conjunto de ações e medidas de assistência e serviços médicos (BOSCHETTI, 2006). Após a inclusão dos termos "assistência" e "previdência" na Constituição Federal de 1934, as legislações de alguns IAPs passaram a implementar direitos designados como auxílios, em um caráter tipicamente assistencial, tais como auxílio-doença, auxílio-maternidade, bonificação de $20 \%$ sobre os salários de trabalhadores cujas esposas não trabalhavam, auxílio-reclusão, auxílio-funeral e auxílio-moradia (BOSCHETTI, 2006). Além disso, o texto constitucional deixou clara a distinção entre seguros e auxílios: de um lado, ficaram estabelecidos como seguros o seguro-saúde, o seguro-invalidez, o seguro-velhice e o seguro-morte; de outro, os auxílios ficaram restritos aos auxílios-natalidade e auxílio-funeral. Essa distinção entre seguros e auxílios perdurou até a Constituição Federal de 1988, quando os auxílios-natalidade e funeral passaram definitivamente a ser benefícios garantidos pela assistência social e materializados por tal política.

Nos seus primeiros anos, a previdência social brasileira, apesar de dominada pela lógica do seguro, não tinha tal característica como exclusiva. Ainda que de forma pontual, a previdência começou a comportar benefícios orientados pela lógica assistencial para serem concedidos aos trabalhadores. Tais benefícios passaram a constituir uma ampliação da proteção social, o que tornou tênues as diferenças no interior do sistema previdenciário entre ações de assistência e de previdência. Nesse sentido, nos anos 1970, a criação de um benefício previdenciário para pessoas com deficiência e idosos pobres, a Renda Mensal Vitalícia (RMV), e a instituição da Aposentadoria Rural para os trabalhadores rurais, que não exigia a contribuição para sua concessão, esfumaçaram ainda mais os limites entre o sistema 
previdenciário securitário e os princípios assistenciais fundamentais para alargar a cobertura da proteção social aos trabalhadores no Brasil (BOSCHETTI, 2006). Se, do interior do sistema de previdência social, os limites entre previdência e assistência poderiam ser nebulosos, a estruturação da Legião Brasileira de Assistência (LBA), nos anos 1940, não deixou dúvida de que a materialização da assistência social ainda não encontrava recepção nas prerrogativas do poder público. Isto é, a responsabilidade de materialização e expansão da assistência social ficaria a cargo da LBA por longos anos. A LBA contava apenas com o repasse de orçamento público para financiar as ações. Mas a estrutura, a elaboração de diretrizes e a execução de ações coletivas ainda estavam a cargo sobremaneira das instituições de caridade.

No interior do sistema previdenciário, com o passar dos anos os benefícios assistenciais cresciam mais em princípios do que em cobertura como medida de alargamento da proteção aos trabalhadores (BOSCHETTI, 2006). Essa curiosa reinvenção dos limites da lógica do seguro do sistema previdenciário para ampliações capazes de alargar a proteção social aos trabalhadores tinha duas causas e duas consequências. A primeira causa poderia ser creditada ao estrangulamento natural que o sistema previdenciário sofria ao ter sido estruturado primordialmente na lógica do seguro. Isto é, aos poucos, a lógica do seguro que materializava benefícios previdenciários em espécie se tornaria insuficiente para todas as necessidades dos trabalhadores. A segunda possível causa foi a de que o universo de vulnerabilidades sociais tão presentes na sociedade brasileira provocaria os limites da rede de cobertura da previdência social. Ao testar a elasticidade da rede previdenciária lato sensu com a introdução de benefícios previdenciários voltados para a população de baixa renda (como a Renda Mensal Vitalícia), benefícios não contributivos (como a aposentadoria rural) e serviços não necessariamente previdenciários (como a assistência médica), a proteção social previdenciária buscou dar respostas às questões latentes de desigualdades sociais históricas do Brasil.

Como consequência, essa sutil metamorfose interna à previdência no que diz respeito à sua lógica do seguro teve um papel conservador: as mudanças no alargamento da proteção social que poderiam ser afiançadas às demais pessoas estavam limitadas aos trabalhadores do regime formal de previdência. Por fim, as ações de assistência social voltadas para os trabalhadores tiveram o efeito reverso ao não suscitar nos debates públicos a necessidade de ampliação de tais medidas para a população de modo geral, retardando o processo de 
transformação da assistência como direito de todas as pessoas, independente de sua vinculação ao trabalho, e acima de tudo como responsabilidade do Estado.

Paralelamente ao surgimento de ações assistenciais dentro do sistema previdenciário, a rede de assistência social sustentada pelas instituições da LBA crescia em número e importância a partir dos anos 1940 no Brasil. Entre 1945 e 1964, a LBA, com corpo próprio de funcionários e dotada de estrutura administrativa, expandiu-se para todo o país: estava presente em 90\% dos municípios brasileiros em 1945 (BOSCHETTI, 2006). Desde a sua criação, em 1942, o financiamento da LBA era oriundo das contribuições previdenciárias de empregados e empregadores. Em 1945, ela passou a contar com recursos apenas dos empregadores e a receber, além disso, doações particulares. Desse modo, as ações da LBA tinham características singulares: eram de iniciativas tecnocráticas, não eram asseguradas em marcos legislativos, não dispunham de um orçamento definido de forma clara e objetiva e, apesar de serem implementadas majoritariamente por funcionários do corpo da instituição, podiam ser executadas também por grupos voluntários que praticavam a caridade e a benevolência (BOSCHETTI, 2006). Para que se tenha uma noção do crescimento e da presença das instituições da LBA, na qualidade de principal ação que oferecia assistência aos pobres, em 1981, mais 8 milhões de pessoas foram atendidas por algum dos oito maiores programas da entidade (SPOSATI, 1985). Em 1984, a LBA contava com mais de 8 mil funcionários distribuídos em seus mais de 2 mil equipamentos assistenciais, tais como creches, centros sociais e abrigos, além de repassar recursos para mais de 6 mil entidades filantrópicas que também executavam algum tipo de programa de assistência social (SPOSATI et al., 1985).

Em 1985, no primeiro ano da Nova República, após o fim do regime militar, a publicação do primeiro Plano Nacional de Desenvolvimento (PND I) traria inovações para a prática da assistência social no Brasil. O PND I anteciparia muitas iniciativas e, especialmente, princípios que estariam contidos nas políticas sociais criadas a partir da Constituição Federal de 1988. A busca pela universalização da saúde, a seletividade dos benefícios previdenciários, a descentralização da gestão das políticas sociais e a integração e racionalização de diversos programas assistenciais foram a tônica do PND I e incentivaram os debates a respeito da construção da seguridade social na Constituinte (BOSCHETTI, 2006). Como componente do PND I, o Ministério da Previdência e Assistência Social elaborou o Plano Nacional de Assistência Social. 
Esse foi o primeiro momento em que a assistência social foi reconhecida institucionalmente como política pública (BOSCHETTI, 2006). Era o Ministério da Previdência e Assistência Social que financiava, por meio da Secretaria de Assistência (SAS), da LBA e da Fundação Nacional do Menor (Funabem), todas as ações públicas, filantrópicas e caritativas de assistência social. O Plano Nacional de Assistência Social teve a característica política e histórica do reconhecimento da assistência social como política pública, mas também a importância técnica de inseri-la em um planejamento estratégico de desenvolvimento social no qual ela passaria por análises técnicas e acompanhamento por parte dos gestores governamentais. Eram os primeiros passos do reconhecimento da assistência como possibilidade na estrutura da administração pública, embora a Política Nacional de Assistência Social do PND I tenha logrado pouco ou nenhum êxito.

Ao final dos anos 1980, a trajetória da assistência social, enfim, encontraria condições políticas, estruturais e jurídicas para a expansão de cobertura para todas as pessoas que dela necessitassem. A vinculação com as prerrogativas para fortalecimento do Estado republicano, de um lado, e a existência de um ordenamento jurídico capaz de recepcionar a assistência na sua dimensão de política de seguridade social, de outro, passaram a levar a sério a concepção de dignidade humana como fundamento do Estado democrático de direito em um momento de reabertura democrática a partir de 1985, após mais de duas décadas de regime militar no país (TAVARES, 2008). Desse modo, a assistência como componente da seguridade social encontraria no texto constitucional promulgado em 1988 o amparo jurídico e político para se assentar na perspectiva da promoção da cidadania. Até então, o sistema de proteção social brasileiro estava amparado na proteção aos trabalhadores ao ponto de restringir a experiência da cidadania no país ao universo do trabalho (SANTOS, 1979). Em seu estudo clássico, Cidadania e justiça: as políticas sociais na ordem brasileira, Santos (1979, p. 75) afirma que as raízes da cidadania no país

encontram-se, não em um código de valores políticos, mas em um sistema de
estratificação ocupacional, e que, ademais, tal sistema de estratificação
ocupacional é definido por norma legal. São cidadãos todos aqueles
membros da comunidade que se encontram localizados em qualquer uma das
ocupações reconhecidas e definidas em lei.

Isto é, a relação que o Estado estabeleceu com a sociedade para a mediação dos conflitos sociais em busca da amenização das situações de privação material, ao longo do século XX, foi dependente da estruturação das proteções legais limitadas ao mundo formal do trabalho. Sendo assim, a promoção da cidadania se constituiu num processo inacabado no 
Brasil, onde as tarefas do Estado na promoção da justiça social lançavam mão de políticas sociais redistributivas limitadas.

A República inacabada no Brasil (FAORO, 2007) e uma espécie de cidadania préfabricada, até o final dos anos 1980, deixaram de fora um contingente enorme da população que não desfrutara das benesses de uma sociedade capitalista de economia cada vez mais diversificada e urbanizada, mas ainda não tinha enfrentado efetivamente a desigualdade social estruturante das relações sociais no país. O traço característico das mediações dos conflitos sociais produzidos pela intervenção do Estado na economia era que se concediam direitos trabalhistas, sociais e coletivos em períodos de ditaduras e regimes militares, como no Estado Novo, de Getúlio Vargas, e depois, a partir do regime militar de 1964 (DRAIBE; AURELIANO, 1989). Esse modelo de intervenção estatal serviu para envolver a classe trabalhadora e para dissimular as forças políticas contestadoras que não levariam adiante os conflitos e as reivindicações políticas por melhorias nas condições de vida da população em geral. Decorrente desse modelo de cooptação de classes ao conceder direitos sociais, é latente, ainda no início do século XXI, uma cidadania incompleta no Brasil, em que a sociedade é profundamente demarcada por desigualdades e injustiças.

Para reformular o modelo de cidadania no Brasil, a estruturação da política de seguridade social a partir da Constituição de 1988 enfrentaria grandes desafios. O baixo crescimento econômico e as altas taxas de desemprego e inflação, acentuadas durante toda a década de 1980, impulsionaram ainda mais os debates durante o período da Constituinte no que dizia respeito à urgência de a Constituição Federal incorporar elementos capazes de enfrentar as graves situações de desigualdade acumuladas ao longo do século XX. As históricas situações de desigualdade social no Brasil - que remetem a uma abolição da escravidão inconclusa (LOBO, 2008), a um processo tardio de urbanização e industrialização e a uma modernização do aparelho do Estado que reproduziu e ampliou desigualdades ao fazer uso da prática tutelar dos trabalhadores (BOSI, 1996) - impactaram nas diversas dimensões necessárias para converter a avançada concepção de seguridade social estabelecida no texto constitucional de 1988 em práticas efetivas de reparação de injustiças sociais nos anos subsequentes.

Pela primeira vez, o ordenamento jurídico e político destinava ao Estado o papel central na elaboração de medidas de redução das desigualdades sociais. Entretanto, as expectativas criadas a respeito das políticas sociais no Brasil a partir dos anos 1990 não impediram o encontro com velhos paradigmas, modelos históricos ultrapassados e diretrizes 
conservadoras a respeito do enfrentamento das situações de privação material. As amarras do passado e o espírito conservador das práticas privadas de assistência que se arrastaram por séculos no Brasil continuariam influenciando a atuação do Estado no enfrentamento das consequências da questão social, o que não afastaria de vez a fragilidade da assistência social de modo a transformá-la em instrumento que refletisse os valores republicanos e democráticos de garantia da dignidade humana.

\subsection{Assistência e tutela: pobreza individual versus pobreza familiar na política de assistência social a partir dos anos 1990}

Durante o processo da Constituinte, no final dos anos 1980, começaram a ser delineados os desafios para a materialização da assistência social como política de seguridade. A dificuldade de assimilação, por parte de gestores e das classes políticas, da assistência como política de responsabilidade dos poderes públicos suscitaria uma série de reveses nos debates durante a construção das propostas para a seguridade social (BOSCHETTI, 2006). A análise de que o sistema de proteção social brasileiro até então havia se esgotado, em razão da cidadania restrita ou regulada (SANTOS, 1979), levaria cada vez mais à necessidade de rediscussão da ampliação das políticas sociais brasileiras como potencializadoras de universalização do acesso a bens sociais com condições concretas de exercício da cidadania. Se as proteções aos trabalhadores, espinha dorsal do limitado Estado-Providência brasileiro até o final dos anos 1970, em breve teriam de agregar um conjunto de ampliações para a proteção social, os princípios e as estruturas que a assistência social comportaria para promover a cidadania passaram a ser essenciais na esfera dos debates políticos.

O modelo de cidadania amparado na proteção ao trabalhador tutelado deveria se deslocar em direção à promoção da cidadania que vinculasse os indivíduos às possibilidades de exercerem uma vida protegida, como sujeitos de direitos, com garantia das necessidades básicas e com plena capacidade de gozo de uma vida livre de privações materiais e sociais, independente de sua participação no mundo do trabalho (BOSCHETTI, 2006; CASTEL, 1995; SANTOS, 1979). Os primeiros desafios para tal mudança surgiram quando da elaboração das comissões da Constituinte responsáveis pela organização dos debates e das propostas teóricas, filosóficas e políticas para formulação da seguridade social no texto constitucional. A volta a esse período emblemático da história recente do país parece enunciar características fundamentais da relação do Estado com as famílias nas formas de proteção social no Brasil, principalmente o modo como a estruturação da política de assistência deveria 
enfrentar os comportamentos restritivos e conservadores do poder público derivados dessa relação.

A Constituinte se organizou em duas comissões e seis subcomissões para elaboração da proposta a respeito dos direitos sociais, a partir dos quais a seguridade social faria parte do texto da Constituição Federal (BOSCHETTI, 2006). As duas comissões eram as seguintes: 1. Da Ordem Social e 2. Da Família, Educação, Cultura, Esportes, Ciência e Tecnologias de Comunicação. Dentro dessas duas comissões, havia as seguintes subcomissões: 1.1. Dos Direitos dos Trabalhadores e Servidores Públicos, 1.2. De Saúde, Seguridade e Meio Ambiente, 1.3. Dos Negros, Populações Indígenas, Pessoas Deficientes e Minorias, 2.1. Da Educação, Cultura e Esporte, 2.2. Da Ciência e Tecnologia e da Comunicação e 2.3. Da Família, Menor e Idoso.

O debate em torno da assistência social não ganhou comissão nem subcomissão específica na Constituinte, mas fez-se presente em algumas das comissões e subcomissões correlatas (BOSCHETTI, 2006). Além disso, curiosamente, apesar de as comissões terem iniciado os trabalhos com audiências públicas, a assistência social foi a única temática que não contou com essa modalidade de trabalho coletivo para fundamentar as discussões em torno das propostas. Como analisa Ivanete Boschetti (2006), as entidades e os especialistas que participaram dos debates no período da Constituinte sobre a proposta da assistência social ficaram divididos nas subcomissões, nas discussões sobre a família, a infância, as pessoas idosas e as pessoas portadoras de deficiência. Boschetti infere disso que uma das razões dessa divisão é o que comumente se compreende como o objeto de proteção da assistência social, que

indica a histórica clivagem existente entre os trabalhadores capazes e aqueles tidos como incapazes de trabalhar. O debate sobre a assistência social é, portanto, associado a essa categoria de miseráveis, ou seja, dos incapazes de assegurar a própria sobrevivência em função das impossibilidades físicas e mentais (ou decorrentes da idade), e, sobretudo, em função de sua condição socioeconômica (2006, p. 148).

A arguta análise de Boschetti encontra várias evidências históricas, na evolução do desenvolvimento das ações públicas ou privadas voltadas para a assistência social, que descrevem essa política de forma limitada, como se ela se destinasse a oferecer proteção apenas àqueles incapazes de manter sua sobrevivência (CASTEL, 1995; DONZELOT, 1973; PEREIRA, 2006b). Todavia, o fato de não ter havido na Constituinte uma subcomissão específica para a discussão da assistência social e de esta ter ficado no bojo das temáticas família, infância, pessoas idosas e pessoas portadoras de deficiência pode indicar também 
outra característica singular do caso brasileiro: a responsabilidade de proteção social dos indivíduos é historicamente compartilhada entre o Estado e as famílias. Essa relação é tão forte que nem mesmo o debate da Constituinte a respeito da construção das novas bases para a assistência foi capaz de abalar.

É claro que a discussão da assistência social como política de seguridade social tem a ver com as temáticas da família. É possível argumentar que, do mesmo modo, os subgrupos temáticos, tais como os de crianças, idosos e pessoas com deficiência, têm estreita relação com a instituição familiar. Essa proximidade justificaria a diluição da discussão da assistência nos debates da Constituinte em meio às demais temáticas relacionadas à família. No entanto, não é apenas a aproximação temática que pode explicar o fato de a discussão da assistência social ter acontecido com os temas da família. Uma histórica justaposição entre o papel das práticas privadas de caridade, a filantropia e as responsabilidades da família na proteção social dos indivíduos dificulta o movimento de o Estado assumir a promoção da assistência como prerrogativa da esfera das responsabilidades públicas. Sendo assim, há experiências nas quais ficaram evidentes as articulações entre Estado e família na função de proteção social dos indivíduos, como resultante de ações públicas ou conjunturas políticas, culturais e sociais específicas do cenário brasileiro. Do interior das práticas de caridade e filantropia, voltadas seja para as situações de privação materiais, seja para educação, assistência em saúde, abrigo ou alimentação, entre outras, o Estado sempre relegou às famílias a responsabilidade inicial de proteção social dos indivíduos.

Essa não é uma exclusividade do caso brasileiro, pois também se identificou nos países europeus (DONZELOT, 1973; ESPING-ANDERSEN, 1991) e nos demais países latino-americanos (SUNKEL, 2006). As instituições e práticas de proteção social aos indivíduos como responsabilidade do Estado foram montadas onde a família não estava ou não podia estar presente. O Estado intervém desde que a instituição familiar não esteja cumprindo primeiramente com as suas funções de proteção, apoio, tutela, assistência e cuidados dos indivíduos. Essa relação - tanto quanto a relação entre assistência e disciplina para o trabalho e a concepção de que a assistência é a que protege somente os incapazes — é determinante para compreender a estruturação histórica das práticas de caridade como proteção social dos indivíduos no Brasil e os desafios da assistência como política pública a se expandir ao superar esse modelo a partir dos anos 1990. 
3.3.1 A proteção das famílias no ordenamento político e jurídico pré-Constituição de 1988

Antes de analisar as consequências da metodologia utilizada no período da Constituinte - em que se discutiu a assistência junto às demais temáticas da família — e os impactos dessa escolha para os anos subsequentes, vale investigar o panorama no qual, do ponto de vista jurídico e constitucional, o Estado brasileiro estabeleceu suas relações com a família na proteção social dos indivíduos. Ao analisar os textos constitucionais anteriores à Constituição Federal de 1988 e o espírito jurídico e político de cada época, desde a Constituição do Império de 1824, passando pelas de 1891, 1934, 1937, 1945 e 1967, verificase uma característica marcante que as particulariza: em seus textos proclamados, sempre houve um descompasso entre os objetivos e princípios declarados e as condições culturais e institucionais em recepcionar tais inovações jurídicas (GONÇALVES, 2009). Isto é, os traços culturais, políticos e históricos do Brasil em cada época das declarações constitucionais sempre entravam em contradição com o espírito das perspectivas jurídicas ensejadas em cada Constituição. Isso se deveu à importação de valores jurídicos dos países europeus, sem levar em consideração as particularidades históricas brasileiras (GONÇALVES, 2009). Além disso, uma das principais características da elaboração dos textos constitucionais anteriores foi a não participação da sociedade nos debates acerca de sua elaboração. No Brasil, a participação democrática da sociedade na elaboração da Carta Constitucional só aconteceria no período da Constituinte do final dos anos 1980.

Como decorrência desse padrão das constituições anteriores, era de se esperar o afastamento entre os princípios declarados nos textos constitucionais e a realidade brasileira para a qual o ordenamento jurídico se dirigia. Por um lado, a assimilação da população a respeito dos valores constitucionais ou da "consciência jurídica" impediria quaisquer avanços no que diz respeito ao aperfeiçoamento dos valores jurídicos e políticos presentes na sociedade brasileira (GONÇALVES, 2009). Por outro, as repetidas elaborações de Constituições sem a participação da população aumentavam a distância entre as prerrogativas constitucionais e a realidade a que elas se destinavam. Se era comum esse procedimento na elaboração das Constituições anteriores, mais afastadas ainda estavam as práticas de intervenção privadas ou coletivas das instituições de caridade. Ou seja, pouco ou nada havia de relação entre o ordenamento jurídico que dizia respeito ao papel do Estado em atender às necessidades básicas da população e as práticas de caridade institucionalizadas como medidas morais e paliativas de amenização da situação de privações. 
Esse é um dos motivos pelos quais a organização da assistência social como política de seguridade social no período da Constituinte no final dos anos 1980 era tão desafiante. A participação democrática na elaboração do texto constitucional e, entre as várias temáticas, da seguridade social precisaria romper com traços do passado, dirigir-se a um futuro imprevisível e ainda estar articulada com o espírito da época. Isto é, deveria buscar atender a todos os anseios da sociedade naquele período de reabertura democrática e responder a dívidas históricas no que dizia respeito a como os governos assumiam a responsabilidade de promover justiça social por meio de políticas sociais reparadoras de desigualdade. Se, de um lado, a caridade sempre amenizou as situações de pobreza, miséria e abandono, de outro, essas ações não tinham vinculação com o ordenamento jurídico brasileiro. Havia uma expectativa de que essa vinculação ocorresse na Constituição Federal a ser promulgada em 1988.

O modo como o texto constitucional anunciaria a relação entre o papel do Estado e das famílias na proteção social dos indivíduos seria emblemático no sentido de que, pela primeira vez, seria explicitada a responsabilidade específica de cada um e aquelas responsabilidades comuns a ambos. Por vários motivos, a Constituição Federal de 1988 foi inaugural para afirmar e criar condições efetivas para o exercício da cidadania no Brasil. O compartilhamento de responsabilidades entre Estado e família na proteção social dos indivíduos como condição para o funcionamento das políticas sociais certamente foi uma dessas novidades.

Entre o período colonial, o período imperial e os primeiros anos da Velha República, as proteções às famílias se limitavam ao universo das ações de caridade para combater privações sociais e proporcionar um incremento de serviços paliativos de assistência em saúde. Já no decorrer das primeiras décadas do século XX, as proteções aos trabalhadores por meio de direitos e garantias previdenciárias alargaram os serviços de proteção social às famílias. Embora a relação entre Estado e família até a Constituição de 1988 fosse marcada pela prática da caridade e limitada às proteções aos trabalhadores e a seus dependentes, no final dos anos 1930, começou a surgir uma série de debates a respeito do modo como o Estado getulista deveria proteger de forma mais abrangente a família brasileira diante de seu suposto enfraquecimento devido aos processos de urbanização e industrialização instaurados no país nas primeiras décadas do século XX (SCHWARTZMAN, 1980).

Não é uma tarefa simples acessar o espírito da época, por meio dos debates políticos, para descortinar os trajetos e as escolhas políticas a fim de determinar os rumos dos governos 
ao afiançar leis que protegessem a família nessa perspectiva. Desse modo, os debates em torno do projeto de lei de um Estatuto da Família proposto em 1939 por Gustavo Capanema, ministro da Educação durante o Governo Vargas, é emblemático (SCHWARTZMAN, 1980). A análise do estatuto pode fazer aparecer os posicionamentos políticos e morais a respeito de como o Estado e a família deveriam se articular para a proteção social dos indivíduos naquele momento de modernização do aparelho do Estado, de industrialização e de expansão de direitos sociais.

De acordo como Simon Schwartzman (1980), a década de 1930 foi representativa de um intenso movimento de mobilização católica por meio de lutas políticas que buscavam restaurar um conjunto de práticas e valores cristãos alegadamente enfraquecidos ou ameaçados. Foi nesse período de mobilizações católicas e de uma intensa aproximação e participação da Igreja em muitos setores do governo do Estado Novo getulista que nasceu a proposta do Estatuto da Família (SCHWARTZMAN, 1980). Desde a Proclamação da República, em 1889, o catolicismo não figurava como a religião oficial do Estado brasileiro. No entanto, a declaração de secularismo e laicidade não impedia a atuação de grupos católicos para fazer valer seus princípios. Pelo contrário, a separação entre Igreja e Estado em 1889 incentivava tal ativismo católico. Para Schwartzman (1980), foi dessa separação entre a Igreja e o Estado declarada na virada do século XIX para o XX que certo ativismo católico passou a colocar na pauta de debates políticos várias temáticas religiosas travestidas de conotações seculares em nome da proteção à família.

Alegava-se que a proposta do Estatuto da Família contribuiria para a discussão de alternativas para pensar a administração pública por meio de uma política demográfica de aumento das taxas de natalidade, o que contribuía para o mercado de trabalho, o desenvolvimento social e econômico do país, as arrecadações etc. Todavia, no fundo, o conteúdo da proposta do Estatuto da Família visava reforçar valores católicos em torno do casamento, do pátrio poder, do não incentivo à entrada das mulheres no mercado de trabalho para se dedicarem aos cuidados do lar, e dos casamentos legítimos, entre outras ações voltadas para o fortalecimento da família católica (SCHWARTZMAN, 1980).

O Estatuto da Família tinha como objetivo incentivar a criação de medidas que facilitassem os casamentos legítimos, tais como a consideração do casamento religioso como casamento civil, os incentivos de empréstimos para habitação a homens casados e os abonos para as situações de maternidade, além de abonos salariais para famílias de prole numerosa (SCHWARTZMAN, 1980). Além disso, o Estatuto defendia a criação de assistência na área 
privada, assistência à infância e à adolescência. Para além dessas proteções explícitas às famílias, havia proteções ao próprio homem como chefe de família: propunha-se, no Estatuto da Família, o incentivo a preferências para que homens casados entrassem no funcionalismo público, além de restrição à participação da mulher em empregos privados e públicos (SCHWARTZMAN, 1980). Diante de tantos aspectos doutrinários conservadores do catolicismo, a reação de Getúlio Vargas foi de muita reticência com o projeto de seu ministro da Educação. Ao pedir pareceres de assessores sobre a proposta, recebeu respostas contrárias à aprovação do projeto, mas com justificativas impressionantes. O parecer que fundamentou a decisão de Vargas contra o Estatuto não foi exatamente porque o presidente discordava do conteúdo do Estatuto da Família, mas porque foi constatado que grande parte das principais reivindicações do Estatuto da Família já estavam contempladas em outras legislações em vigor, tais como as trabalhistas, previdenciárias, de educação, de apoio à infância etc.

Para Shwartzman, "a legislação não passaria pelo fato de que o Governo Vargas preferia sempre a legislação pragmática e casuística à legislação doutrinária e ideológica" (1980, p. 74). A contra-argumentação de Capanema ao parecer contrário de Vargas ao projeto do Estatuto foi a de que, embora o ministro concordasse que muitas das reivindicações estivessem mesmo em outras legislações já em vigor, a proposta do Estatuto da Família era a de fortalecer tais iniciativas dispersas no ordenamento jurídico até então ao organizá-las em um único regulamento. O Decreto 3.200, de 1941, aprovado e assinado por Getúlio Vargas, retirou boa parte do conteúdo ideológico da proposta inicial de Capanema e, ao mesmo tempo, outras medidas de assistência à família foram criadas, tais como o Departamento Nacional da Criança, ligado ao Ministério da Justiça, e a própria LBA, em 1942, que inicialmente era ligada ao mesmo ministério (BOSCHETTI, 2006). Se o Estatuto da Família com seu conteúdo ideológico não foi aprovado, qual seria a importância desse documento para a genealogia do familismo nas ações de assistência social no Brasil? O estatuto simboliza os ideais políticos nesse momento inaugural de atuações do Estado brasileiro perante as proteções sociais, principalmente no que diz respeito às motivações e as convicções políticas e filosóficas sobre a divisão de responsabilidades entre Estado e família na proteção social dos indivíduos.

A proposta do Estatuto da Família do Estado Novo getulista é emblemática não pelo que a discussão do Estatuto conseguira materializar na conversão do projeto em lei efetiva, mas, sobretudo, naquilo que ele conseguiu organizar e suscitar no debate político acerca do que já era levado a cabo para fortalecer a família como instituição importante na sociedade 
brasileira modernizada, urbanizada e industrializada do século XX. Ao lado dessa proteção à família, surgiu uma série de ações de assistência, tanto dentro do sistema previdenciário, como já salientado anteriormente, quanto na própria formatação das ações de assistência no interior da LBA, tendo como objetivos centrais a refamiliarização do sujeito, a sua proteção para torná-lo familiarizado, ou seja, com condições de convívio com a família (FOUCAULT, 2006). Essas ações de refamiliarização dos sujeitos são explícitas na obrigação das famílias de mandar seus filhos para a escola, de vaciná-los, de enviá-los para o exército e depois para o mercado de trabalho. Aparecem, também, na proteção-punição aos adolescentes que cometem crimes e serão cuidados pela Funabem. Portanto, a novidade do estatuto não estava no ato inaugural de estabelecer o padrão de atuação do Estado em parceria com as famílias para proteger os indivíduos. Isso já estava em curso no Brasil. A novidade foi esse despertar de uma consciência política, moral e governamental naquilo que diz respeito à inteligibilidade dos governos em assumir que a refamiliarização dos indivíduos já fazia parte de várias ações públicas e privadas de outras instituições e também de direitos afiançados pelo Estado.

Parece haver um contrassenso em afirmar o quanto a discussão em torno do Estatuto da Família pode representar um exemplo de reforço do espírito do familismo no Brasil. Pois, se o Estado está incentivando políticas para a proteção da família, isso seria o oposto do familismo como uma prática em que as famílias assumem a responsabilidade de provisão das necessidades dos indivíduos. Entretanto, as ações do Estado direcionadas ao reforço das famílias explicitadas na discussão sobre o Estatuto da Família na Era Vargas não estavam exatamente relacionadas à proteção social dos indivíduos em prestações materiais de responsabilidade do Estado para alguma situação de privação. Eram medidas em sua maioria direcionadas a direitos trabalhistas, ao papel dos homens e das mulheres no que dizia respeito a um conjunto de proteções e relações tanto com a instituição casamento quanto com os cuidados no interior das famílias, o patrimônio e o mundo do trabalho. As ações de apoio à autonomia dos indivíduos desvinculadas do mundo do trabalho, ao oferecer atendimento às necessidades para livrar as pessoas das privações, ainda não faziam parte das discussões públicas.

Ao solicitar o reforço da família, a discussão em torno do Estatuto da Família impeliu o Estado a oferecer respostas às demandas familiares ou a reforçar que tais demandas já estivessem sendo atendidas por outras ações legais. Para o mundo do trabalho e o reforço de papéis masculinos e femininos nas dinâmicas familiares, o Estado se movimentou. Mas, quanto às proteções sociais voltadas ao atendimento de necessidades básicas, o Estado 
transferiu para a iniciativa privada ou deixou a cargo das famílias tais atribuições, que estariam presentes até os anos 1990, quando da regulamentação da assistência social na LOAS em 1993 após o preceito constitucional assinalado na Constituição de 1988 (BOSCHETTI, 2006). O que as discussões em torno do Estatuto da Família evidenciam é que, no universo do Estado capitalista, jamais a formulação de políticas sociais para atendimento de necessidades básicas dos indivíduos ocorreria sem enfrentar os entraves em torno do compartilhamento de responsabilidade entre o Estado e as famílias nessas atribuições.

As motivações e convicções presentes na proposta do Estatuto da Família de 1939 permaneceriam praticamente inabaláveis no imaginário político até o final dos anos 1980. Nesse ínterim, basta lembrar a importância das reivindicações das famílias brasileiras que levaram ao golpe militar de 1964 e a duração da ditadura por mais de duas décadas no Brasil, tendo o apoio da família tradicional, principalmente de matriz católica, durante todo o regime de restrição democrática (FAUSTO, 2001). Já no período da Constituinte, o reforço da relação entre assistência e família apareceu mais uma vez pela discussão da assistência social nas temáticas das subcomissões da Constituinte relacionadas à família. Na Constituinte, o objetivo das discussões políticas não era apenas elaborar a proposta de uma assistência social com abrangência capaz de ir além das práticas da caridade, mas superar tais características ao oferecer mais que proteções exclusivas aos trabalhadores.

A discussão da elaboração da assistência social no quadro mais geral da seguridade social na Constituinte deveria enfrentar também estratégias para desfamiliarizar as políticas de bem-estar social e não promover o familismo, como inicialmente a discussão da assistência na comissão e nas subcomissões de família resultaria. Era desse cenário de mais de quatro séculos de caridade e de relações conservadoras do Estado na proteção social no Brasil que o período da Constituinte deveria partir para elaborar a proposta de articulação da assistência no universo da seguridade social. O descompasso nos debates filosóficos e jurídicos no Brasil era cada vez mais latente no que diz respeito às atribuições dos governos em desenhar, financiar e materializar políticas de bem-estar social que, aos poucos, provocassem a desfamiliarização das políticas sociais, isto é, a diminuição da participação das famílias nas provisões sociais (ESPING-ANDERSEN, 1991). Certamente, tratar da construção da política de assistência em temáticas correlatas às da família criaria obstáculos potentes na discussão dos princípios e objetivos a estruturarem a assistência social numa perspectiva de desfamiliarização das políticas sociais. 
Para o texto da Constituição de 1988, a definição da especificidade da assistência social como direito de seguridade social precisava se articular não só com os objetivos que estruturariam o Estado democrático de direito, tais como os fundamentos da cidadania e da dignidade, como também com os objetivos fundamentais republicanos de erradicação da pobreza e das desigualdades (BRASIL, 1988). Principalmente, a assistência precisaria se afastar de práticas tradicionais que pudessem impedir o cumprimento de tais objetivos republicanos. A discussão da estruturação da assistência social dentro da temática geral da família tinha grandes chances de impedir esses rompimentos com práticas tradicionais e restritivas de proteção social. Pela primeira vez, a sociedade civil participaria da elaboração do texto constitucional e, consequentemente, da definição do sistema de seguridade social. Entretanto, a discussão da assistência atrelada à discussão das temáticas familistas poderia reforçar o histórico compartilhamento das responsabilidades do Estado com as famílias na proteção social dos indivíduos e não buscar alternativas para superá-lo. O que estava em jogo nesse cenário era como as políticas sociais materializadas pelo Estado levariam a sério o fundamento da dignidade humana, ou seja, o tratamento do Estado a todos os indivíduos como fins em si mesmos. Tratar da assistência junto da temática da família retardaria esse processo, uma vez que o direito pensado nessa lógica poderia ser traduzido como um direito das famílias e não dos indivíduos.

Com esses desafios, os debates durante a Constituinte e, mais adiante, na regulamentação da assistência social, com a elaboração da Lei Orgânica em 1993, teriam de dialogar com forças históricas que delinearam o sistema de proteção social no Brasil. Segundo Geraldo Di Giovanni (1998), a proteção social, mesmo quando capitaneada por forças do Estado, não tem essa via como exclusiva, pois ainda concorre com pelo menos dois tipos principais: o primeiro tipo de proteção social é aquele em que predominam as práticas tradicionais, baseadas nos valores da solidariedade, fraternidade, caridade e filantropia, práticas desenvolvidas tendo como principais instituições a família e as redes de vizinhança, por meio de ações religiosas e das mais diversas entidades de ajuda mútua. Em segundo lugar, encontram-se os sistemas de proteção social estruturados nas trocas realizadas nas práticas econômicas. Nesse sistema, o acesso a serviços de proteção social se dá de forma individual ou coletiva por intermediações de mercados, envolvendo pagamentos às prestações de serviços, ou seja, as práticas comerciais estão no cerne do acesso às proteções sociais (DI GIOVANNI, 1998). Essas três modalidades de proteção social - em que o Estado é o elemento-chave, em que a família e as instituições de caridade são elementos-chave e em que 
as proteções encontram no mercado o elemento-chave - não são excludentes entre si no contexto das sociedades. Ao contrário, coexistem nos diversos países e, a depender de fatores econômicos, históricos, culturais e políticos, entre outros, uma modalidade pode ter predominância em relação a outra, tendo impacto na proteção ou desproteção dos indivíduos.

3.3.2 Proteção às crianças, aos idosos e às pessoas com deficiência na Constituição de 1988: o familismo por meio do critério de pobreza familiar e o familismo do tipo compartilhamento

As discussões sobre os direitos das crianças e adolescentes, os direitos dos idosos e os direitos das pessoas com deficiência foram incisivamente influenciadas pela discussão da assistência atrelada às temáticas da família no período da Constituinte (MIOTO; CAMPOS, 2003). Não só materializado no texto constitucional, mas se espraiando para a LOAS, aprovada em 1993, para o Estatuto da Criança e do Adolescente (ECA), aprovado em 1990, e para o Estatuto do Idoso, tardiamente aprovado em 2004, o espírito do familismo influenciaria explicitamente o paradigma de mediação entre o Estado e as famílias na provisão de bemestar social na virada do século XX para o XXI. Os traços de familismo na política de assistência social voltada para crianças, idosos e pessoas com deficiência não decorrem exclusivamente do fato de que, desde o período da Constituinte, a discussão da assistência social veio atrelada às temáticas desses subgrupos da família. $\mathrm{Na}$ verdade, houve uma continuação histórica de procedimentos no que diz respeito às ações do poder público em lidar com as temáticas da família. Essa continuação fez com que tais ações, mesmo elaboradas em ambiente favorável à expansão da proteção social pela participação democrática no período da Constituinte, encontrassem dificuldades em se desvencilhar de padrões históricos no comportamento político que limitavam a cobertura da assistência ao destinar parte das responsabilidades às famílias.

Não era tarefa simples para os debatedores do período da Constituinte enfrentar as forças do passado. Era preciso um redesenho da assistência social na perspectiva dos direitos. Para tanto, os constituintes precisariam fragilizar a ideia da assistência como prática privada que buscava amenizar as situações de miséria por meio da caridade durante séculos no Brasil, além de superar a centralidade da família como primeira entidade responsável pela provisão de bens materiais aos indivíduos. Nesse sentido, a assistência social ainda dialogaria constantemente, nos primeiros anos da década de 1990 e a partir dos anos 2000, com essas forças do passado. É possível falar em impedimentos ideopolíticos e morais presentes em uma sociedade de predomínio católico, como é a brasileira, o que dificultava às forças políticas, 
durante os debates da Constituinte, perceber a assistência na perspectiva dos direitos e não na perspectiva moral de ajuda aos mais necessitados (PEREIRA, 1996). Essa ruptura necessária com o passado não viria no cenário das discussões políticas para a promulgação da Constituição. Não viria nem mesmo com a criação de leis infraconstitucionais nos anos subsequentes que materializariam a setorialidade da política de assistência social para os diversos públicos aos quais a política estava destinada.

No texto constitucional, o capítulo VII é reservado para os direitos de proteção das famílias, das crianças, dos adolescentes, dos jovens e dos idosos (BRASIL, 1988). Foi a partir desse capítulo que se aprovou o ECA, em 1990, o Estatuto do Idoso, em 2004, e o Estatuto da Juventude, em 2013. É nesses estatutos que os direitos desses três grupos são detalhados, bem como as formas de exercê-los e garanti-los. No que diz respeito ao texto constitucional, vale destacar a explicitação, no artigo 227, de que "é dever da família, da sociedade e do Estado assegurar à criança, ao adolescente e ao jovem, com absoluta prioridade, o direito à vida, à saúde, à alimentação, à educação, ao lazer, à profissionalização, à cultura, à dignidade, ao respeito, à liberdade e à convivência familiar e comunitária [...]” (BRASIL, 1988). Para além da importância dos deveres assinalados no texto constitucional, o que é mais emblemático nesse artigo é a preponderância da família sobre a sociedade e o Estado, no tocante à proteção à criança, ao adolescente e ao jovem, como assinalado no artigo 229 da Constituição: “os pais têm o dever de assistir, criar e educar os filhos menores, e os filhos maiores têm o dever de ajudar e amparar os pais na velhice, carência ou enfermidade" (BRASIL, 1988).

No caso dos idosos, para combater a prática do asilamento indevido pelas famílias, no parágrafo primeiro do artigo 230 ficou estabelecido que "os programas de amparo aos idosos serão executados preferencialmente em seus lares" (BRASIL, 1988), prerrogativa que seria reforçada em 2004, com a aprovação do Estatuto do Idoso (BRASIL, 2004). Porém, como exigência positiva, esse artigo acabou por transferir para as famílias a responsabilidade do cuidado dos idosos, mesmo sem aludir àquelas famílias que não podem fazê-lo. Desde o texto constitucional, há uma preponderância sobre o papel da família na proteção social de crianças, adolescentes, jovens e idosos em comparação às responsabilidades do Estado. Essa interpretação só seria forçosa e equivocada caso, nos anos subsequentes, não houvesse desdobramentos para confirmar esse familismo nas práticas de proteção social. O que se verifica, porém, é o aprofundamento dessas transferências de responsabilidade do Estado para as famílias nas provisões materiais e sociais de seus membros à medida que as políticas setoriais vão sendo criadas (MIOTO; CAMPOS, 2003; MIOTO; LIMA, 2006). 
Já no ECA, o poder familiar foi não só criado, como restaurado e aumentado no que diz respeito às provisões oferecidas pelas famílias às suas crianças e seus adolescentes. Isto é, o ECA não teve o papel de destituir o poder familiar perante crianças e adolescentes, mas de instaurá-lo, regulá-lo, potencializá-lo, na medida em que uma série de ações e políticas foram destinadas ao poder público para garantir proteções e assistência, mas sem privar as famílias do poder. Nos artigos 19, 22 e 23, por exemplo, é possível verificar uma precisa conclusão a respeito da prioridade dada no ECA ao direito de a criança e o adolescente permanecerem no convívio familiar. No artigo 19, ficou estabelecido que é direito das crianças e dos adolescentes serem criados e educados na própria família ou, na impossibilidade desta, numa família substituta. A destituição do pátrio poder, uma prática recorrente até então, em que a impossibilidade da família de sustentar os filhos resultaria na destituição do poder familiar e na consequente transferência da criança e do adolescente para um instituição de abrigo, deixou de existir. A partir de então, para garantir a permanência da criança na família, esta deve obrigatoriamente ser incluída em programas oficiais de auxílio e de assistência social, tais como de transferência de renda.

Em todos esses casos sobre os direitos das crianças e dos adolescentes, assim como no dos idosos, é bastante significativa a instauração de uma modalidade de proteção social necessária às crianças, aos adolescentes e aos idosos, mas por meio de um compartilhamento de responsabilidade entre o Estado e as famílias. Esse compartilhamento não seria prejudicial se houvesse a presença maciça de políticas públicas e sociais que garantissem os direitos básicos das crianças, dos adolescentes, dos jovens e dos idosos. Todavia, o que se percebe, na década de 1990 e nos anos 2000, é ausência de ações públicas robustas voltadas para esse público, o que faz com que as famílias assumam responsabilidades de proteção além daquelas previstas no ordenamento legal.

Para os direitos das pessoas com deficiência, o traço mais característico do familismo na estruturação da assistência no texto constitucional ficou a cargo da previsão feita no artigo 203, inciso V, da Constituição, sobre a "garantia de um salário mínimo de benefício mensal à pessoa portadora de deficiência e ao idoso que comprovem não possuir meios de prover à própria manutenção ou de tê-la provida por sua família, conforme dispuser a lei” (BRASIL, 1988). Esse artigo constitucional foi regulamentado pela LOAS, aprovada em 1993, dando origem ao Benefício de Prestação Continuada da Assistência Social (BPC). O BPC é destinado tanto às pessoas com deficiência quanto às pessoas idosas na extrema pobreza, o 
que significa que, para a concessão do benefício, o requerente deve viver em família cuja renda per capita não ultrapassa 1/4 de salário mínimo (BRASIL, 2011b).

Embora regulamentado na LOAS, em 1993, o BPC só foi efetivado em 1996 e, hoje, constitui um dos principais programas de transferência de renda de combate à pobreza e às desigualdades em vigor no Brasil (CAMPELLO; NERI, 2013; MEDEIROS; BRITTO; SOARES, 2007; VAITSMAN; ANDRADE; FARIAS, 2009). Segundo dados do Ministério do Desenvolvimento Social e Combate à Fome, em fevereiro de 2014, mais de 2,1 milhões de pessoas com deficiência e mais de 1,8 milhão de pessoas idosas recebiam o BPC (BRASIL, 2014b). Pelo fato de exigir que a provisão de manutenção e sustento do requerente do BPC, para ensejar o direito ao benefício, não seja apenas do próprio indivíduo, mas de sua família, o benefício tem um caráter mais familista do que propriamente de um direito individual à assistência social.

É sabido que a proteção social do BPC não se resume ao repasse mensal no valor de um salário mínimo às pessoas idosas e às pessoas com deficiência. Principalmente após 2004, com a criação da Política Nacional de Assistência Social, os beneficiários do BPC são inseridos em programas de acompanhamento pelos equipamentos da rede socioassistencial, como os Centros de Referência em Assistência Social (CRAS) e os Centros de Referência Especializados em Assistência Social (CREAS), bem como nos Serviços de Atenção Integral à Família (PAIF) (BRASIL, 2011b). Isso significa que a proteção aos beneficiários do BPC se estende desde o repasse da renda mensalmente até a cobertura de uma rede de segurança social que promove a integração das pessoas na vida social e comunitária, além de prever situações de agravos e riscos sociais (BRASIL, 2011b).

Entretanto, essa possibilidade de proteção ampliada aos beneficiários do BPC não afasta a restrição da cobertura do benefício pelo critério de renda per capita familiar de 1/4 de salário mínimo, nem pelo fato de que o benefício só será concedido desde que a família não tenha condições de garantir as provisões para manutenção do indivíduo. Na porta de entrada do benefício, a necessária avaliação da possibilidade de a família manter o indivíduo significa um compartilhamento de responsabilidade da proteção social das pessoas idosas e das pessoas com deficiência entre o Estado e as famílias que afasta o teor do benefício da sua vinculação com a promoção da dignidade humana e da cidadania, como se esperava da política de assistência social na década de 1980. Isto é, apesar de representar um importante direito, inclusive, expresso no texto constitucional, o preceito do artigo 203 que resultaria no BPC não 
é para todas as pessoas idosas e com deficiência na extrema pobreza, mas somente para aquelas pessoas idosas e com deficiência cujas famílias não consigam prover sua manutenção.

Para Maria Paula Dallari Bucci (2006), em sociedades com menor tradição de garantia de liberdades individuais e menos desenvolvidas socioeconomicamente, como no Brasil, a afirmação de direitos sociais como aconteceu na Constituição de 1988 só faz sentido se estiver associada a um conjunto de garantias equivalentes ao que permitiu que os direitos individuais, civis e políticos se transformassem em referencial jurídico do Estado democrático de direito. Essas características aumentam a pressão e a responsabilidade pela materialização dos preceitos constitucionais, no sentido de que os direitos sociais funcionam como instrumentos de proteção contra as privações sociais e, ao mesmo, podem ser descritos como meios para proteger a igualdade, a liberdade e a autonomia das pessoas (CASTEL, 2005; HERRERA, 2008). É nesse sentido que os objetivos fundamentais do Estado democrático brasileiro estabelecidos na Carta constitucional de 1988 dizem respeito não somente ao restabelecimento dos valores democráticos, mas também às aspirações relativas à criação de condições para superação da profunda desigualdade socioeconômica do país (BUCCI, 2006). Quando a regulamentação da assistência social criou as possibilidades de compartilhamento de responsabilidade com as famílias, o Estado abriu brechas para que a assistência social não se desgarrasse de vez de práticas tradicionais que ofereciam meros recursos paliativos ao anunciar combater as situações de pobreza e desigualdades sociais.

Estabelecer a exigência de que, primeiro, será avaliado se a família tem condições de prover o sustento do indivíduo para depois conceder o direito ao benefício assistencial afasta as possibilidades de delineamento da assistência como política de proteção da dignidade humana, por não tratar os indivíduos como fins em si mesmos. Somado a isso, levar em consideração o restritivo critério de $1 / 4$ de salário mínimo per capita por família reforça o caráter familista do benefício em um momento em que a assistência social precisaria alcançar voos maiores na sua articulação com os objetivos republicanos das garantias factuais de políticas públicas baseadas nos fundamentos da dignidade e da cidadania. Avaliar primeiramente se a família tem condições de prover o sustento dos indivíduos para depois afirmar o direito à assistência enfraquece tanto o fundamento da dignidade quanto o da cidadania. Essa exigência, inicialmente do BPC, estende-se a todos os benefícios assistenciais introduzidos com as políticas de transferência de renda materializados no final dos anos 1990 e início dos anos 2000 no país (SILVA; YASBEK; DI GIOVANNI, 2004). O caráter familista 
pelo critério de renda familiar e pela expectativa de proteção inicial das famílias será o traço principal da assistência social no Brasil a partir dos anos 2000.

A pobreza familiar previamente avaliada como critério concessório do benefício assistencial impede a compreensão da assistência social como direito individual básico protetor da dignidade e da cidadania. Nesse sentido, o acompanhamento dos impactos que o critério de renda da legislação do BPC poderia trazer para o sistema de proteção social brasileiro e para a garantia do direito fundamental da assistência social, na sua articulação com a cidadania e dignidade, não passou despercebido pelas instituições de controle social, jurisdicional e democrático no país.

Desde a regulamentação da LOAS, projetos de lei, arguições jurídicas e estudos acadêmicos problematizaram a focalização do BPC pelo critério de pobreza familiar e a ameaça à compreensão da assistência social como direito fundamental (PENALVA et al., 2010). Os questionamentos sobre os critérios de elegibilidade do BPC no Judiciário começaram antes mesmo da promulgação da LOAS, em dezembro de 1993 (BOSCHETTI, 2006; BRASIL, 1993). Em novembro de 1993, foi impetrado no Supremo Tribunal Federal (STF) o Mandado de Injunção 448, que exigia a regulamentação do artigo 203, inciso V, da Constituição Federal de 1988, que daria origem ao benefício assistencial (PENALVA et al., 2009; STF, 1993). A demora da regulamentação do artigo 203 por meio da promulgação da LOAS cinco anos depois da Constituição de 1988 motivou o mandado de injunção. Logo após a aprovação da LOAS e o estabelecimento das diretrizes que regulamentariam o BPC, em 1995, foi proposta a Ação Direta de Inconstitucionalidade (ADI) 1.232, que levantava a tese da inconstitucionalidade do critério de renda per capita familiar de 1/4 de salário mínimo como limite para que uma pessoa deficiente ou idosa se tornasse elegível ao benefício (STF, 1999). Desde então, o Judiciário passou a ser responsável por constantes questionamentos a respeito de como o BPC tem sido operacionalizado, como uma espécie de guardião da política pública, e também de como esse benefício tem materializado direitos sociais.

A ação de controle de constitucionalidade questionava que, ao definir o limite de $1 / 4 \mathrm{de}$ salário mínimo para a concessão do repasse mensal, a legislação do benefício assistencial apontava "a incompatibilidade das disposições transcritas com o art. 203, V, da Constituição Federal" (STF, 2009), o que poderia excluir outros possíveis sujeitos elegíveis ao BPC. Embora, no texto constitucional, o BPC fosse um direito voltado para idosos e pessoas portadoras de deficiência pobres que seria regulamentado de acordo com lei infraconstitucional, a assistência social ficou estabelecida na Constituição como direito de 
seguridade social não contributivo destinado a quem dela necessitasse. Ou seja, o texto constitucional expressou que o repasse mensal seria regulamentado por lei específica, no caso a LOAS, mas o teor da ADI compreendeu que a especificação de quem seriam as pessoas pobres atendidas pelo BPC, na lei infraconstitucional, poderia provocar uma controvérsia em relação ao estabelecido na Constituição sobre para quem seria a assistência social. Após três anos, a ADI foi julgada improcedente pelos ministros do Supremo Tribunal Federal por maioria de votos, em 27 de agosto de 1998.

É papel das instâncias legislativas e executivas definir os aspectos que serão levados em consideração no momento de decidir quais características individuais e sociais são imerecidamente injustas e, portanto, carentes de prevenção ou remoção por meio de políticas públicas e sociais. Essa tarefa dos poderes Executivo e Legislativo não é simples, sobretudo, em um ambiente democrático. Mas os representantes desses dois poderes, que são eleitos democraticamente pelas maiorias, possuem legitimidade para tais decisões. E, uma vez tomadas as decisões de forma transparente e democrática, a própria política pública tem de contar, em seu desenho, com instrumentos que deixem espaço para constantes adequação e revisão, mesmo depois da política implementada.

O desenho de qualquer política pública ou social deve, portanto, incorporar: 1. quais desigualdades injustas devem ser prevenidas ou removidas, 2. como repará-las por meio do que será ofertado e 3. quanto de recursos públicos será destinado a elas. Cada política pública tem objetivos específicos e é avaliada em termos de razoabilidade, eficiência e eficácia (BUCCI, 2006). Diferentes temas ascendem ou não ao patamar de necessidade de intervenção pública orientada a objetivos específicos, o que pode ser resultado de diferentes pressões políticas e sociais ou da própria conformação dos governos e da sociedade dispostos a acatar ou não tais pressões (ROCHA, 2005). O processo de revisão judicial de uma política pública ocorre legitimamente quando todas essas fases são previstas no desenho e escopo das políticas, mas por algum motivo não são cumpridas.

Três anos depois da decisão do STF no caso da ADI 1.232, os juízes federais da $4^{\mathrm{a}}$ Região recolocaram na pauta das discussões judiciais o critério de pobreza do BPC, dessa vez, reinterpretando a decisão da suprema corte, ao reforçar a ideia de que a avaliação da pobreza familiar para concessão do BPC deve ser utilizada apenas como um dos parâmetros e não como limite acima do qual seja possível excluir beneficiários. Mas os juízes da Região Sul não estavam solitários na reinterpretação da ADI 1.232 dada pelo STF. Após a decisão do STF, os juízes de outras regiões do país continuaram a se pronunciar pela insuficiência do 
critério de pobreza de 1/4 de salário mínimo, deixando para cada juiz a possibilidade de levar outros fatores em avaliação para determinar a elegibilidade da pessoa ao BPC (TAVARES, 2008). Assim, a Súmula 6 da $4^{\text {a }}$ Região foi cancelada em 7 de julho de 2006 (JUSTIÇA FEDERAL DA $4^{\mathrm{a}}$ REGIÃO, 2009), mas durante sua vigência serviu para problematizar o critério de pobreza e fundamentar decisões processuais envolvendo o BPC.

O fato é que a reinterpretação da decisão do STF quando julgou a ADI 1.232, como demonstra a Súmula 6 da $4^{\text {a }}$ Região, não estava restrita aos limites da Justiça Federal da Região Sul e a ideia ganhou força em várias regiões do país. Juízes federais em outras unidades da Federação seguiam orientações semelhantes às dos juízes da Região Sul, o que provocou constantes reclamações do Instituto Nacional do Seguro Social (INSS), instituição que executa o benefício assistencial, perante o STF, informando-o sobre o descumprimento por juízes federais da decisão da suprema corte na ADI 1.232 (PENALVA et al., 2010; TAVARES, 2008). Em fevereiro de 2008, no Recurso Extraordinário 567.985, de relatoria do ministro Marco Aurélio de Mello, em que o INSS reclamava à suprema corte sobre a concessão do BPC nas instâncias primárias da Justiça a idoso com renda familiar per capita de 1/2 salário mínimo, o STF reconheceu a existência de Repercussão Geral a respeito do critério de pobreza para o benefício assistencial. Em abril de 2013, a ação de Repercussão Geral foi julgada e declarada procedente, tornando, portanto, inconstitucional o critério de um 1/4 de salário mínimo (STF, 2013).

A decisão do STF afastou o critério objetivo de 1/4 de salário mínimo para concessão do benefício assistencial, alterando-o para 1/2 salário mínimo e equiparando-o com outros benefícios assistenciais, como o Bolsa Família, que, desde o final dos anos 1990, leva em consideração a pobreza como renda familiar de 1/2 salário mínimo. A decisão do STF devolveu a responsabilidade para o Poder Legislativo, que deve reformular o artigo da Lei 12.435, de 2011. Além disso, passou a desconsiderar que a renda de um beneficiário do BPC possa incidir sobre a renda familiar de outro requerente. Isto é, até essa decisão do STF, ao contabilizar a renda familiar de uma pessoa idosa ou de uma pessoa com deficiência para a concessão de um segundo BPC para a mesma família, se o critério de renda ultrapasse 1/4 de salário mínimo, o benefício não era concedido. Essa alteração era uma reivindicação antiga e objeto de constantes processos judiciais.

Uma análise mais detalhada desse momento da judicialização do BPC no Brasil nas últimas duas décadas está em minha dissertação de mestrado, publicada em 2009 (SANTOS, 2009). Esse conjunto de análises e reflexões é trazido para a discussão do familismo na 
assistência social com dois principais objetivos: o primeiro deles é evidenciar o quanto o Poder Judiciário esteve atento a todo o processo de execução da política de assistência social a partir dos anos 1990. Por meio do acompanhamento da execução do BPC, guiando-se principalmente pelos princípios constitucionais, da dignidade humana e da cidadania, para rever a execução do BPC, o Poder Judiciário conseguiu alterar, inclusive, alguns parâmetros de operacionalização da política assistencial (SANTOS, 2009). Essa perspectiva, em grande medida, elucida o quanto a ideia da assistência social como direito humano fundamental tem se institucionalizado cada vez mais no ordenamento político, legislativo e judiciário no Brasil.

O segundo motivo para trazer esse histórico de judicialização do BPC é o de ressaltar que, embora as atuações e decisões do Poder Judiciário tanto na concessão quanto no controle de constitucionalidade do BPC tenham sido efetivas e vanguardistas no que diz respeito à ampliação do critério de renda para alargar a proteção social do BPC, a atuação judicial não problematizou a lógica familista desse critério. Isto é, o debate em quase duas décadas sempre foi no sentido de estender o limite do critério de renda per capita familiar, e não de questionar a lógica familiar como critério de concessão. As preocupações do Poder Judiciário sempre incidiram sobre o maior limite da renda que as famílias poderiam ter para fazer jus ao benefício, não questionando se esse critério poderia representar uma ameaça para a materialização do direito fundamental. O BPC está sendo analisado aqui não só pela sua importância no universo dos benefícios assistenciais de transferência de renda desde os anos 1990, mas, principalmente, porque é um benefício assistencial com potencial para ser efetivado às pessoas com transtornos mentais oriundas dos Estabelecimentos de Custódia e Tratamento Psiquiátrico, público-alvo desta tese.

Dispor de ações voltadas para a proteção social das famílias não é o mesmo que familismo ou familiarização da proteção social. Não são todas as práticas que protegem as demandas familiares e que livram os indivíduos das privações materiais e sociais por meio de proteções amplas às famílias que resultarão em familismo na proteção social. De um lado, não só os indivíduos têm demandas por necessidades a serem atendidas, mas também as famílias precisam ser atendidas em suas demandas integrais. De outro, o direcionamento das ações públicas não pode se dar no sentido de reforçar a responsabilidade familiar pelas provisões, eximindo o Estado, com suas políticas públicas, do papel de atender as necessidades básicas de todas as pessoas. Em nenhum momento se pretende eliminar ou levantar suspeitas sobre o papel e os deveres das famílias no que diz respeito ao cuidado dos indivíduos e das formas coletivas de superação de situações de privação. A análise dos traços do familismo na 
assistência social busca evidenciar o quanto os padrões presentes nas políticas públicas podem reforçar graus de opressão e desigualdade quando reforçam a transferência de responsabilidade da proteção social do Estado e dos governos para as famílias.

Como será discutido na seção seguinte, a política de assistência social não se resume ao BPC. Há um conjunto de ações, benefícios e programas que materializam serviços sociais numa estrutura ampla da política de assistência social, o Sistema Único de Assistência Social (SUAS), criado em 2005 por decreto presidencial e afiançado legalmente pela Lei 12.435, aprovada em 2011. Embora avançada em termos de princípios e cobertura, a Política Nacional da Assistência Social também não conseguiu se desvencilhar dos traços de familismo em suas ações, principalmente por forças legais que compartilham ou transferem para as famílias a responsabilidade pela provisão material e social dos indivíduos. A análise da Política Nacional de Assistência Social é capaz de elucidar os traços de familismo na política de assistência que ganhou força no período da Constituinte e que continua representando um desafio para a ampliação da proteção social brasileira na perspectiva dos direitos de cidadania.

\subsection{BPC, Bolsa Família e o Serviço de Atenção Integral à Família nos anos 2000: do ocaso e da tutela ao familismo do tipo transferência e do tipo omissão}

A reescritura da assistência social amparada na seguridade social não foi capaz de se converter em resultados objetivos na implementação das ações da assistência social em seguida da expressão constitucional em 1988. O preceito constitucional da assistência social no artigo 203 da Constituição Federal levaria cinco anos para ser regulamentado e apenas em 1993 a Lei Orgânica da Assistência Social foi aprovada (BOSCHETTI, 2006). Essa demora na regulamentação não representou o último entrave para a materialização e expansão da assistência social como política de seguridade. A assistência social ainda enfrentaria uma série de reveses na formatação da política, pois os ambientes político e econômico no Brasil, hostis a essa formatação, fizeram com que a assistência social não se desvinculasse de determinantes históricos do passado. A partir do momento em que a história da assistência social começava a ser recontada, agora no âmbito da articulação com as demais políticas de seguridade e proteção social, o cenário econômico de intensa instabilidade pelo baixo crescimento econômico acumulado desde a década perdida dos anos 1980 e as altas taxas de desemprego e inflação, além dos escândalos políticos do governo do presidente Fernando Collor de Melo (1990-1992), que começaram exatamente na pasta da política de assistência social, tornaram 
os descaminhos da assistência tortuosos para seu amadurecimento e desenvolvimento nos anos 1990.

Não foram apenas os descaminhos internos do cenário brasileiro que impactaram na política de assistência social, que se arrastou ao longo dos anos 1990 antes de decolar com a importância de que a política de seguridade necessitaria. As profundas reestruturações produtivas no capitalismo internacional, para responder às sucessivas consequências da crise econômica global do final dos anos 1970, influenciaram profundamente o reordenamento dos ditames internacionais a respeito dos ajustes macroeconômicos para que as economias capitalistas ao redor do mundo pudessem enfrentar a crise de produção (HARVEY, 1996). A reorientação para o fortalecimento do mercado financeirizado, a flexibilização dos processos de trabalho e os intensos desdobramentos para destituição de direitos trabalhistas e sociais conquistados ao longo da Era de Ouro do Capitalismo passaram a ser justificativas para conter os gastos públicos e realinhar as economias. Como consequência, tais ajustes macroeconômicos estruturais passaram a ditar certas regras econômicas sagradas a partir do início dos anos 1990: para dar fôlego às economias globais e recuperar os rumos macroeconômicos do capitalismo central e periférico, os ideias neoliberais de baixa intervenção estatal na economia e de retração de investimento nos setores produtivos passaram a ter como objetivo principal a garantia das altas taxas de lucro e a acumulação do capital, passando a imperar medidas de contenção de gastos públicos.

Fatores externos e internos ao cenário econômico e político brasileiro fizeram com que não só a política de assistência social, mas as demais políticas públicas e sociais fossem enxugadas nos anos 1990, tendo como justificativa os ajustes econômicos e a contenção de gastos públicos. O resultado foi a agudização das situações de privação e vulnerabilidade acumuladas, que o país ainda não tinha enfrentado (LINHARES, 2011). O crescimento do terceiro setor e intensos processos de desresponsabilização do Estado pela execução de políticas sociais foi a tônica dos anos 1990, por meio de um processo de transferência, para setores da sociedade civil organizada, de responsabilidade dos poderes públicos em materializar, financiar e executar políticas estruturais do sistema de proteção social brasileiro (MONTAÑO, 2002). O impacto para o escopo da proteção social brasileira foi devastador. A miríade ensejada na Constituição Federal de 1988 pelo avanço da inscrição da assistência social como política de seguridade social ficou cada vez mais distante de se concretizar.

A responsabilidade pela proteção social foi transferida, em grande medida, do Estado para a sociedade civil por meio do financiamento público de entidades do terceiro setor, do 
reforço às antigas instituições de caridade e da inovadora prática do voluntariado (MONTAÑO, 2002). Essa lógica acabou por robustecer o familismo já presente na política de assistência social que havia sido instaurada por vários elementos do texto constitucional recém-promulgado, como analisado no item anterior. Além disso, os ajustes macroeconômicos ditados pela ideologia neoliberal nos anos 1990, que pregava a retração dos investimentos públicos nas políticas sociais, focalizaram nos mais pobres as ações de assistência social, criando barreiras para potencializar a universalização da seguridade social. Foi desse cenário desfavorável ao alargamento da proteção social brasileira nos anos 1990 que surgiram as primeiras iniciativas isoladas de benefícios de transferência direta de renda para famílias na extrema pobreza, como o Bolsa-Escola, no final dos anos 1990 (SILVA; YASBEK; DI GIOVANNI, 2004). Entre a cruz e a espada, as iniciativas por meio desses programas de transferência de renda acabaram por resultar em esperança de novas possibilidades de expansão da política de assistência social no país. E foi exatamente esse processo que acabou por ocorrer nos anos 2000.

No final dos anos 1990, um conjunto de experiências com políticas de transferência de renda deu início ao processo inovador que impactaria definitivamente no escopo da assistência social no Brasil a partir dos anos 2000 (SILVA; YASBEK; DI GIOVANNI, 2004). Iniciativas isoladas tanto no Distrito Federal quanto no estado de São Paulo concederam um auxílio mensal a famílias na extrema pobreza, por meio de um repasse pecuniário com valor variável de acordo com a quantidade de filhos e atrelado ao cumprimento de certas condicionalidades, como permanência na escola e cuidados de saúde, como nutrição e vacinação dos filhos (SILVA; YASBEK; DI GIOVANNI, 2004). Essas primeiras iniciativas do que viria a ser um dos maiores programas de transferência de renda do mundo começaram a chamar a atenção pela inovação de articular, intersetorialmente, as políticas de assistência social, saúde e educação numa rede complexa de promoção da cidadania e de alargamento da proteção social. Aos poucos, as iniciativas isoladas começaram a surtir efeito, o que chamou cada vez mais atenção e despertou para estender o programa Bolsa-Escola para o âmbito nacional.

Segundo Maria Ozanira da Silva e Silva, Maria Carmelita Yasbek e Geraldo di Giovanni (2004), os anos 1990 representam um período de profunda contradição no campo do bem-estar social no Brasil. De um lado, houve um avanço no plano político-institucional, representado pelo estabelecimento da seguridade social e dos princípios de descentralização e de participação social, enunciados na Constituição de 1988. Mas, de outro, houve, no plano da 
intervenção estatal, um movimento orientado por posturas restritivas, com a adoção de critérios de cada vez maior rebaixamento do corte de renda para fixação da linha de pobreza, para permitir o acesso das populações aos programas de transferência de renda, em grande expansão no Brasil, a partir de 2001. Assim, não se verificou a necessária expansão de programas e serviços sociais numa conjuntura na qual o crescimento da pobreza demandasse mais atenção do Estado em relação ao atendimento das necessidades coletivas básicas da população trabalhadora.

As políticas de combate à pobreza focalizadas nos mais pobres foram resultantes de ditames internacionais de organismos multilaterais como Banco Mundial, Banco Interamericano de Desenvolvimento (BIRD) e Fundo Monetário Internacional (FMI) (SILVA; YASBEK; DI GIOVANNI, 2004). Ao conceder vultosos empréstimos financeiros aos países endividados, esses organismos internacionais ditavam um conjunto de orientações a serem seguidas pelos países, entre elas, o corte de gastos no orçamento público e os direcionamentos para as políticas sociais focalizadas. As experiências vividas no Brasil da centralidade das políticas de transferência de renda para as famílias mais pobres foi também um receituário verificado em vários países de capitalismo periférico, principalmente na América Latina, entre outros países pobres do Hemisfério Sul. Era preciso superar os entraves para o alargamento dos sistemas de proteção social, dos quais os baixos investimentos de recursos públicos para as ações eram apenas um. O cenário de retração de investimentos públicos para sustentar as políticas, principalmente as de seguridade social, levaram ao fortalecimento das famílias como provedoras do bem-estar social dos indivíduos (LINS, 2013; SUNKEL, 2006). Esse fortalecimento pôde ser verificado não apenas no Brasil, mas também em outros países da América Latina (SUNKEL, 2006). Era preciso fortalecer a ideia de que, sem investimentos públicos, a estruturação da seguridade social não ocorreria como necessário. No entanto, deveriam ocorrem ainda outros movimentos importantes de rompimento com práticas conservadoras das medidas de proteção social no país.

Cilene Lins (2013) analisa que o familismo na política de assistência social entre 1998 e 2010 deveu-se, sobretudo, a dois processos correlacionados: o primeiro foi a mudança na estrutura das famílias brasileiras, que, de numerosas até os anos 1970, passaram a ser paulatinamente menores, tendo a mulher como principal provedora. Essa mudança teve impactos objetivos sobre as proteções primárias que as famílias (especialmente as mulheres no cuidado dos membros familiares) sempre ofereciam, em razão de a proteção social ainda não ter sido uma prática encampada pela responsabilidade estatal. Em segundo lugar, o 
ambiente neoliberal nos anos 1990 e 2000, principalmente no que toca à retração do papel do Estado em financiar políticas sociais de promoção de bem-estar social, acabou por transferir para as famílias a responsabilidade de provisão social dos indivíduos. Não era apenas o ambiente político e econômico que era desfavorável ao destravamento da política de assistência social como capaz de incorporar à política de seguridade social o papel de promoção do bem-estar. O ideário neoliberal teve a consequência imediata de reforçar o papel das famílias ao transferir para elas a responsabilidade de proteção social dos indivíduos em um momento em que a estrutura familiar passava por mudanças profundas no Brasil.

Essa abordagem não é unívoca e homogênea na leitura do cenário brasileiro. O reforço do voluntariado, de práticas tradicionais de caridade e de filantropia, bem como do papel das famílias na proteção social, foi facilitado pelas dificuldades em organizar a assistência social como política pública institucionalizada nos níveis federal, estadual e municipal (DRAIBE; AURELIANO, 1989). Essas dificuldades encontram sustentação em vários precedentes históricos anteriores ao cenário econômico dos anos 1990. A não institucionalização da assistência social tem uma série de determinantes além do ideário neoliberal, embora esse seja um dos principais fatores. À medida que o preceito constitucional da assistência social como direito de seguridade social não encontrava recepção no arcabouço administrativo por meio da estruturação de políticas sociais robustas, a proteção social ficou cada vez mais dependente das práticas tradicionais de cobertura dos indivíduos, pela mobilização da comunidade, pela caridade e também pela atuação das famílias. Desse modo, o necessário amadurecimento da política de assistência social a partir dos anos 2000 teria de enfrentar como nunca práticas tradicionais para promover a desfamiliarização da proteção social no país. A partir de 2004, com a publicação da Política Nacional de Assistência Social, a desfamiliarização deveria ter ocorrido. No entanto, a unificação das ações de transferência de renda isoladas no país no Programa Bolsa Família, a criação do Serviço de Atenção Integral à Família e a estruturação da rede da Política Nacional de Assistência Social não atingiriam tal objetivo.

O familismo presente na política de assistência social a partir da estruturação do direito de seguridade social por meio da Política Nacional de Assistência Social, em 2004, não é devido ao simples fato de que o termo família aparece até no nome dos dois principais instrumentos de materialização da assistência social nos anos 2000: o Programa Bolsa Família (PBF) e o Serviço de Atenção Integral à Família (PAIF). Também é possível falar de continuísmo do familismo na política de assistência social no Brasil nos anos 2000 porque, mais do que nunca, a família assumiu as responsabilidades que seriam do Estado na promoção 
de bem-estar dos indivíduos. Entre os oito anos de governo do presidente Fernando Henrique Cardoso, do Partido da Social Democracia Brasileira (PSDB), entre 1995 e 2002, e os oito anos de governo do presidente Luiz Inácio Lula da Silva, do Partido dos Trabalhadores (PT), entre 2003 e 2010, houve profundas diferenças no que toca à estruturação e ao fôlego da expansão da política de assistência social. Mas, sobre a prevalência do familismo na assistência social, embora de formas distintas, essa foi uma característica comum ao governo FHC e ao governo Lula.

A hostilidade do cenário econômico internacional e nacional fez os oitos anos do governo do PSDB apresentarem tímidos avanços na área social, principalmente devido ao ambiente neoliberal, que pregava a restrição de investimentos em políticas sociais. Desde o governo anterior, do presidente Itamar Franco, do final de 1993 até 1994, houve a implantação pontual da política de assistência social, em que a família passaria a ser o eixo central de atenção das ações. No governo FHC, a prioridade foi dada à implantação do Núcleo de Atendimento Familiar (NAF) e, no governo Lula, essa política passou a ser o principal eixo da Política Nacional de Assistência Social, por meio do Sistema Único de Assistência Social, transformando-se em Programa de Atenção Integral à Família (PAIF), agora, Serviço de Atenção Integral à Família. A implantação de ações centradas nas famílias pobres acompanhou as mudanças estruturais no mundo do trabalho, assim como as diretrizes de organismos internacionais como Banco Mundial, BIRD e FMI.

No governo FHC, a assistência social ficou totalmente dependente do programa Comunidade Solidária. O programa fora criado e coordenado pela primeira-dama, Ruth Cardoso. Com poucos impactos na redução da pobreza e da desigualdade social no país, o Comunidade Solidária promoveu um resgate da filantropia e tinha por objetivo fortalecer redes solidárias nas regiões com baixo Índice de Desenvolvimento Humano (IDH) e com concentração de pobreza (SILVA; YASBEK; DI GIOVANNI, 2004). No período de 1996 a 1998, o governo FHC criou os programas Brasil Criança Cidadã, de Erradicação do Trabalho Infantil (PETI), de Combate ao Abuso e à Exploração Sexual de Crianças e Adolescentes (Sentinela) e Projeto Alvorada, que selecionava municípios com baixo IDH para focar programas de geração de renda, educação, saúde e assistência social. Além dessas ações, foram criados vários programas compensatórios que apenas se expandiram, como no caso dos programas de transferência de renda no final dos anos 1990 e início dos anos 2000, no final do governo FHC. 
Com a chegada de Luiz Inácio Lula da Silva à Presidência da República, em janeiro de 2003, o combate à pobreza passou a significar uma de suas principais plataformas do governo, chamando a atenção não só do Brasil, mas do mundo sobre a temática. No governo Lula, inicialmente, a política da assistência social era totalmente baseada nas ações em torno do Programa Fome Zero, que mesclava iniciativas dos poderes públicos e da sociedade civil como medidas amplas para combater a fome e a desnutrição infantil. Durante esse governo, foi criado o Ministério da Assistência Social, mas, por envolvimento em uso indevido de recursos públicos, a ministra Benedita da Silva foi afastada e o ministério assumiu outra configuração. Nesse processo, houve a separação entre Previdência e Assistência Social, que adquiriu outro patamar. Desse modo, o Ministério do Desenvolvimento Social e Combate à Fome (MDS) foi criado, por meio da Medida Provisória 163, em janeiro de 2004, transformada na Lei 10.868, de maio de 2004. Na estrutura organizacional do MDS, a assistência social passou a ser de responsabilidade da Secretaria Nacional de Assistência Social (SNAS). Uma das primeiras medidas do MDS foi a de unificar os programas de transferência de renda a famílias pobres. Daí que os programas Bolsa-Escola, Vale-Gás e Programa de Erradicação do Trabalho Infantil (PETI) foram unificados no Bolsa Família, para famílias que vivessem com renda per capita inferior a 1/2 salário mínimo.

Mas a reorganização da estrutura pública da assistência social a partir de 2004 não parou por aí. A assistência social passou a ocupar um espaço institucional próprio: a Secretaria Nacional de Assistência Social, do MDS, ficou responsável pela elaboração da Política Nacional de Assistência Social (PNAS), de 2004. Na PNAS, ficou previsto e definido, pela primeira vez na história da assistência social, o Sistema Único de Assistência Social (SUAS), em atenção a uma recomendação da IV Conferência Nacional de Assistência Social, realizada em Brasília, em 2003. De acordo com a PNAS, os eixos estruturantes do SUAS eram a matricialidade sociofamiliar, a descentralização político-administrativa e a territorialização. Isso significou novas bases para a relação entre Estado e sociedade civil no que diz respeito a financiamento, controle social, política de recursos humanos, informação, monitoramento e avaliação da política. Além disso, na PNAS, dividiu-se o atendimento em três tipos de segurança: de sobrevivência, de acolhida e de convívio (BRASIL, 2004b). Segundo Potyara Pereira,

a segurança de sobrevivência consiste, basicamente, na prestação governamental de um valor monetário mínimo aos idosos e às pessoas com deficiência pobres - não contribuintes da Previdência Social e sem condições de se manter ou ser mantidos por suas famílias - bem como às 
vítimas de calamidades ou de outras contingências sociais. Esta segurança será viabilizada por meio da distribuição do Benefício de Prestação Continuada (BPC), no valor de um salário mínimo, e dos Benefícios Eventuais (em fase de regulamentação), assim como de bolsas-auxílios financeiros condicionais e passíveis de serem objeto de contratos de compromissos. A segurança de acolhida refere-se ao atendimento de demandantes especiais da Assistência Social em espaços físicos e por serviços estrategicamente montados em todo território nacional para prestarem provisões básicas, especialmente as que se referem à alimentação, ao vestuário e à moradia. Por fim, a segurança de convívio diz respeito à construção, restauração e fortalecimento dos laços familiares e comunitários de demandantes da assistência com fracos vínculos afetivos e sociais. Tal segurança requer, igualmente, oferta pública de atividades socioeducativas, culturais e de convivência em espaços definidos (2007, p. 70).

Foram esses arranjos que deram conotação abrangente à política de assistência social a partir da segunda metade dos anos 2000. Em dezembro de 2013, mais de 12 milhões de famílias, que totalizavam quase 45 milhões de pessoas, eram atendidas pelo programa Bolsa Família, com transferências mensais de valores entre $\mathrm{R} \$ 32,00$ e $\mathrm{R}$ \$ 242,00 (BRASIL, 2013). De acordo com o Decreto 8.232, de 30 de abril de 2014, os valores dos benefícios do Bolsa Família mudaram a partir de junho de 2014, sendo o benefício concedido a famílias com renda mensal por pessoa de até $\mathrm{R} \$ 77$ (extrema pobreza) e com renda per capita entre $\mathrm{R} \$ 77,01$ e R\$ 154 (pobreza), desde que, nesse caso, haja crianças, adolescentes, gestantes ou nutrizes. O Benefício Básico, pago às famílias extremamente pobres, é de $\mathrm{R} \$ 77,00$, e o Benefício Variável, pago às famílias pobres e extremamente pobres, que tenham crianças de 0 a 15 anos, gestantes ou nutrizes, é de R \$35,00. Já o Benefício Variável Jovem (BVJ), pago às famílias pobres e extremamente pobres que tenham adolescentes de 16 e 17 anos, é de R\$ 42,00 (BRASIL, 2014b).

Para além da transferência direta de renda do Bolsa Família, as famílias brasileiras recebem ações da assistência social divididas em dois tipos: a proteção social básica e a proteção social especial (BRASIL, 2004b). A proteção social básica é implementada pelos Centros de Referência de Assistência Social (CRAS), equipamentos públicos responsáveis por oferecer atendimento em território delimitado. A proteção social básica tem como objetivo a prevenção de situações de risco por meio do desenvolvimento de potencialidades e aquisições e o fortalecimento de vínculos familiares e comunitários (BRASIL, 2004b). É destinada à população que vive em situação de fragilidade decorrente de pobreza, ausência de renda, acesso precário ou nulo aos serviços públicos ou fragilização de vínculos afetivos (discriminações etárias, étnicas, de gênero ou por deficiências, entre outras). Em 2013, o número de CRAS chegou a 7.986 equipamentos em 5.437 municípios em todo o país 
(BRASIL, 2014b). O Nordeste concentrou a maior proporção de municípios com presença de CRAS (99,5\%), seguido pelas regiões Centro-Oeste $(98,7 \%)$, Norte $(97,6 \%)$, Sudeste $(96,4 \%)$ e Sul $(96,1 \%)$. Já os Centros de Convivência, que apoiam o trabalho social com famílias desenvolvido no CRAS, passaram para mais da metade dos municípios em 2013, com destaque para o Centro-Oeste, com 69,9\% de abrangência.

A proteção social especial destina-se a famílias e indivíduos em situação de risco pessoal ou social, cujos direitos tenham sido violados ou ameaçados (BRASIL, 2004b). Para integrar as ações da proteção especial, é necessário que o cidadão esteja enfrentando situações de violação de direitos por ocorrência de violência física ou psicológica, abuso ou exploração sexual; abandono, rompimento ou fragilização de vínculos ou afastamento do convívio familiar devido à aplicação de medidas socioeducativas no caso de crianças e adolescentes em conflito com a lei. A proteção social especial é executada pelos Centros de Referência Especializado em Assistência Social (CREAS). O número de CREAS chegou a 2.229 equipamentos distribuídos em 2.032 municípios, isto é, os CREAS estão presentes em 36,5\% dos municípios brasileiros (BRASIL, 2014b). O Nordeste apresentou a maior proporção de municípios com esse equipamento, 45,6\%, em seguida, Centro-Oeste $(43,3 \%)$, Norte $(39,8 \%)$, Sudeste $(31,4 \%)$ e Sul $(25,9 \%)$. Em 2013, foram contabilizados 510 Centros-Dia, que são equipamentos de proteção social especial para pessoas com deficiência, idosas e suas famílias, em 290 municípios brasileiros. Já as unidades de atendimento ao adolescente em conflito com a lei, em 2013, eram 1.918, distribuídas em 1.240 municípios (22,3\%) brasileiros (BRASIL, 2014b).

As situações de infância e adolescência, velhice, mulheres, deficiência, desemprego, violência doméstica e demais violações de direitos básicos passaram a receber atenção da política de assistência social por meio de uma rede complexa de serviços, programas e benefícios com cobertura na quase totalidade do território nacional. No entanto, a combinação entre a lógica familista da renda per capita familiar como critério para dar início à proteção social em toda a assistência social (tanto no BPC quanto no Bolsa Família) e a matricialidade sociofamiliar como eixo norteador da política pode ter impactos significativos para a persistência do familismo na trajetória da assistência social. Embora a matricialidade sociofamiliar dê primazia à atenção às famílias e seus membros no território de vivência, com prioridade àquelas mais vulnerabilizadas, representando uma estratégia efetiva contra a setorialização, segmentação e fragmentação dos atendimentos (TEIXEIRA, 2009), quando da ausência de determinadas ações de assistência para públicos específicos, essa centralidade 
sociofamiliar pode representar um desafio para a ampliação da proteção social. É o caso das pessoas com doenças e transtornos mentais e a necessidade de cuidados decorrentes dessa situação que não encontram ainda espaço na agenda das políticas de assistência social, ficando tal proteção totalmente a cargo das famílias.

No marco das políticas de assistência social, não há ações voltadas para proteção das pessoas com doenças e transtornos mentais, bem como suas necessidades de cuidado. Nem tampouco ações de proteção social voltadas para os cuidadores de pessoas com doenças e transtornos mentais. Isto é, as situações de privação social decorrentes de doenças e transtornos mentais que são protegidas pela política de assistência social se resumem ao BPC. É comum pessoas com doenças e transtornos mentais serem consideradas pessoas com deficiência para fins de concessão desse benefício. Desde 2009, quando as formas de avaliação dos requerentes do BPC foram alteradas, há uma maior concessão do benefício nesses casos. Anteriormente, quando a avaliação dos requerentes do BPC estava assentada sobre outras bases e, principalmente, era restrita à perícia médica, situações de doença e transtorno mental não eram claramente delineadas como possíveis de incorrer na concessão do benefício assistencial.

Com exceção do BPC, praticamente inexistem programas, benefícios ou ações no âmbito da assistência social voltados para os cuidados pessoais àqueles com doenças e transtornos mentais. Além disso, a inexistência de programas, benefícios ou ações específicas para os cuidadores das pessoas com doenças e transtornos mentais transforma o tema do sofrimento mental em um fardo para a dinâmica do grupo familiar. Não são todas as situações de sofrimento mental que demandam cuidados cotidianos. Mas, quando tais situações ocorrem, como apoio e assistência para cuidados básicos de alimentação, higiene, integridade e segurança física, acompanhamentos e apoios ao tratamento medicamentoso, terapêutico e psicossocial, os impactos sobre o bem-estar da família são onerosos. Isto é, pela ausência de políticas destinadas a prover cuidados pessoais àqueles com doenças mentais, tais encargos trazem impactos objetivos para a dinâmica socioafetiva, para as desigualdades de poder entre os membros familiares, entre outras situações que interferem no convívio saudável e com autonomia de todos os membros das famílias.

A área de cuidados pessoais na política de assistência social tem sido um tema largamente investigado no sentido de fortalecer a agenda de cuidados como carente de ações públicas (CRUZ, 2011; SOUZA; CARNEIRO, 2007). Nos debates sobre a possibilidade de a política de assistência social incorporar essas demandas, o que vem sendo chamado de linha 
de cuidados tem favorecido estudos e levantamentos acerca do mapeamento das possibilidades de intervenção pública no que diz respeito à necessidade de cuidados por pessoas idosas e com deficiência (CRUZ, 2011). Embora os cuidados pessoais daqueles com sofrimento mental não tenham ascendido ao mesmo patamar das discussões dos cuidados de idosos e pessoas com deficiência, a frente aberta por essa temática no interior da política de assistência social é promissora para o futuro da garantia da autonomia e cidadania desses grupos populacionais.

Da inexistência de ações da política de assistência social voltadas para as pessoas com doenças e transtornos mentais, surge uma variante do familismo que não é mais o familismo do tipo compartilhamento, cuja responsabilidade de provisão é dividida entre Estado e família, como nos casos analisados anteriormente. Para as necessidades das pessoas com doenças e transtornos mentais, o familismo nas ações de assistência social poderia ser caracterizado como o de omissão: é da omissão do Estado que a responsabilidade de assistência e cuidado das pessoas com transtornos mentais é totalmente assumida pelas famílias. Nesse sentido, é recente o papel do Estado na atenção integral às demandas das pessoas com doenças e transtornos mentais, como dispõe o artigo $4^{\circ}$ da Lei 10.216, de 2001: “o tratamento em regime de internação será estruturado de forma a oferecer assistência integral à pessoa portadora de transtornos mentais, incluindo serviços médicos, de assistência social, psicológicos, ocupacionais, de lazer, e outros" (BRASIL, 2001).

Como será analisado no próximo capítulo, a política de saúde mental, assentada sobre novas bases a partir do movimento da reforma psiquiátrica, apenas nas últimas duas décadas encontrou melhores alternativas para um atendimento particularizado das demandas no caso de afecções mentais. Para subverter o paradigma da institucionalização e psiquiatrização da saúde mental reinante durante os séculos XIX e XX no Brasil, a luta antimanicomial desde os anos 1990 busca estabelecer novos serviços de base comunitária com vistas a ofertar serviços de saúde numa perspectiva psicossocial. Ao mesmo tempo em que a reforma psiquiátrica introduzia esses elementos na alteração do paradigma de atenção em saúde mental, a assistência social criava novas possibilidades de ampliação da proteção social no início dos anos 2000. O que ainda não ocorreu foi o encontro da mudança paradigmática da reforma psiquiátrica com a mudança de paradigmas na política de assistência social, resultando na ausência de políticas de proteção social para esses casos.

Com exceção do BPC, não há ações de assistência social que podem ser diretamente voltadas aos indivíduos em sofrimento mental que cumprem medida de segurança. O conjunto 
de programas, benefícios e ações criadas desde 2004, que compõem a política integral de assistência social, se transformou em importante arcabouço para assegurar as necessidades básicas dos indivíduos. Entretanto, há particularidades ainda não cobertas pela política de assistência social. O familismo não se apresenta na política de assistência social apenas pelo critério de pobreza, transformando o BPC em um benefício mais familiar que individual. A depender das situações de privação a ser protegidas e da ausência de ações específicas de assistência social voltadas às pessoas em sofrimento mental, as responsabilidades de provisão social são assumidas pelas famílias dos indivíduos com doenças e transtornos mentais.

Ainda sobre o BPC e os desafios de levar adiante o princípio da dignidade humana como norteador da política de assistência social, uma curiosa medida administrativa de 2007 representa um sério entrave para a expansão do benefício assistencial para quem dele necessitar, principalmente para as pessoas com transtorno mental que cometem crimes e, depois de cumprirem o tratamento psiquiátrico obrigatório sob custódia, devem retornar à liberdade. Na Instrução Normativa 20, de 2007, o Instituto Nacional do Seguro Social (INSS) proibiu a concessão do BPC para os requerentes com deficiência que estivessem reclusos em instituições carcerárias. Assim disciplina o regulamento, no artigo 623, parágrafo $3^{\circ}$ : “o requerente ou beneficiário recluso, devidamente comprovado por órgão carcerário, não fará jus ao Benefício de Prestação Continuada da Assistência Social-BPC-LOAS, uma vez que a sua manutenção está sendo provida pelo Estado" (BRASIL, 2007).

A medida causa estranheza por duas razões. A primeira delas é o fato de a restrição de um direito constitucional ser possível de se consubstanciar por dispositivo administrativo interno a uma autarquia federal. Isto é, uma medida administrativa autárquica assume força de lei e restringe a concessão de um direito constitucional. Tal alteração não poderia ocorrer nem mesmo por um ato simples das casas legislativas brasileiras, dado que se trata de um direito que, para qualquer mudança, requereria emenda constitucional. A segunda razão, talvez a mais importante, é a justificativa enunciada em “[...] uma vez que sua manutenção está sendo provida pelo Estado". Ora, trata-se o BPC de um benefício que materializa o direito à assistência social preceituada no texto da Constituição Federal e regulamentada pela LOAS, de 1993; portanto, é um direito fundamental básico dos indivíduos (TAVARES, 2008).

Ao legislar sobre o benefício assistencial, o INSS ameaça seu caráter de direito subjetivo individual como dispositivo para acesso à assistência social como direito de seguridade social. Apenas em um ambiente político e jurídico em que o direito à assistência social não se configura como um direito fundamental básico a todos os indivíduos que dela 
necessitarem é possível a ocorrência de uma medida restritiva como essa. O estranho não é apenas o fato de se tratar de uma medida meramente técnico-administrativa, tendo como resultado a restrição do direito à assistência social, mas o fato de ser possível tal discrepância porque o direito à assistência social ainda não é compreendido na esfera dos direitos individuais de responsabilidade do Estado, que, ao garanti-lo, protege a dignidade humana. Um cenário de dificuldades em se desvencilhar de práticas tradicionais a respeito da proteção social não consegue promover o amadurecimento da assistência social como política de proteção social porque um ato administrativo que deveria apenas conceder os benefícios assistenciais reforça a proteção social na perspectiva do sujeito tutelado, como foi durante todo o século XX (BOSI, 1996). No lugar de promover a autonomia dos indivíduos por meio de direitos emancipatórios garantidos em quaisquer circunstâncias, o Estado brasileiro transfere para uma instituição carcerária o dever de prover as necessidades dos indivíduos, o que desarticula as possibilidades de vinculação entre a política de assistência social e as prerrogativas dos objetivos republicanos de proteção da dignidade, promoção da cidadania e redução das desigualdades sociais. O sujeito-alvo da política social continua sendo mero instrumento passivo de funcionamento do Estado interventor e não alcança o patamar de sujeito ativo em uma sociedade que prima pela justiça social.

A transferência de provisão material das pessoas com doenças ou deficiências mentais que ascenderiam à elegibilidade ao BPC, a não ser pelo fato de estarem reclusas, apaga a natureza da assistência social e sobrepõe papéis muito distintos entre a política de segurança pública e a de assistência social baseada na tutela das pessoas em cumprimento de medida de segurança. A consequência dessa proibição do INSS a respeito da não concessão do BPC para pessoas com doenças e deficiências mentais sob custódia tem menos a ver com a não provisão material das necessidades sociais dos indivíduos - uma vez que ela ocorre independentemente da qualidade do atendimento, no caso da institucionalização para custódia - do que com a descaracterização dos princípios e objetivos da assistência social. A segurança de sobrevivência por meio da garantia de renda é apenas um dos objetivos — talvez o pré-requisito para os demais - que estruturam os atendimentos na política nacional de assistência (BRASIL, 2004b, 2005). A segurança de acolhida e de convívio é outro objetivo estruturante dessa política, que prima pela busca do empoderamento e da autonomia dos sujeitos. Quando a segurança de sobrevivência ou de rendimento não ocorre, as demais ficam comprometidas e as ações da política não alcançam todos os sujeitos. Ao reduzir os objetivos da assistência social à segurança de sobrevivência — como é a justificativa do ato 
administrativo do INSS —, as possibilidades de ampliação da assistência social encontram barreiras importantes. A interpretação do INSS leva à compreensão de que um equipamento público de segurança pública pode assumir o papel de segurança de rendimentos da política de assistência social, o que interdita as demais possibilidades de proteção social básica e especial importantes para a expansão da cobertura da política de assistência destinada aos indivíduos em sofrimento mental.

O compartilhamento de responsabilidades entre Estado e famílias em alguns casos da política de assistência social; a omissão do Estado, que transfere totalmente para elas a responsabilidade de provisão material e social, para atendimento de determinadas necessidades dos indivíduos, em outras; e a concepção tutelar da assistência (no caso de ser proibida a concessão do BPC para aqueles em instituições carcerárias) são faces da mesma moeda no jogo do familismo nas políticas de proteção social no Brasil. O familismo nas políticas sociais não resulta apenas da força majoritária das famílias na provisão espontânea de proteção social de seus membros. O familismo é ajustado, aperfeiçoado e intensificado por um complexo de ações e inações do Estado na execução de tais políticas. A assistência social como política de seguridade social não visava apenas decodificar a responsabilidade do desenho e da materialização das políticas de proteção social no âmbito das atribuições do Estado, mas ampliar a cobertura da política assistencial ao articulá-la aos princípios jurídicos, políticos e éticos que sustentam o Estado democrático de direito. Apenas a afirmação no texto constitucional não foi suficiente para essa metamorfose da assistência social. As forças do passado, as práticas tradicionais e comunitárias que reforçam o papel das famílias e de instituições na provisão de necessidades básicas de seus membros cimentam o funcionamento restritivo das políticas familistas colocando barreiras à compreensão da assistência social como instância articulada aos princípios da dignidade humana e da promoção da cidadania no ambiente jurídico, político e institucional inaugurado na Constituição Federal de 1988.

\subsection{A assistência social torna-se direito de seguridade social por meio do familismo: o circuito familista}

É inegável o avanço da política de assistência social desde a Constituição Federal de 1988 e, de forma mais contundente, a partir dos anos 2000. O processo de amadurecimento, tecnicidade e profissionalização da assistência social em decorrência da modernização das ações no nível da administração pública tornou possível a ampliação do sistema de proteção social, desde 2004, com a Política Nacional de Assistência Social e, desde 2005, com a 
criação do Sistema Único de Assistência Social. Foi nesse cenário que a política de assistência social no âmbito da seguridade social institucionalizou-se por meio das políticas de proteção no Brasil no seu momento mais contemporâneo.

A caridade forjada por mais de quatro séculos no Brasil retardou a possibilidade de compreensão da assistência social como ação pública vinculada à cidadania e à dignidade humana. Principalmente, as raízes da prática da caridade criaram obstáculos efetivos à compreensão da direção do Estado na responsabilidade em dispor de políticas públicas que materializassem necessidades básicas dos indivíduos. Mesmo com ambiente político favorável e alinhado com as perspectivas jurídicas progressistas no período da Constituinte capazes de oferecer bases legais robustas para uma Constituição Cidadã, a assimilação da assistência social no escopo da seguridade social encontrou impedimentos nos anos subsequentes. Tais impedimentos estão, em grande medida, relacionados aos entraves colocados por forças históricas, políticas e culturais para provocar a substituição do papel espontâneo das famílias em assumir a proteção social dos indivíduos.

Se, nos anos 1990, esses entraves puderam ser elucidados de forma mais evidente, mesmo a partir dos anos 2000, com o enfraquecimento dos ditames que primavam pela redução dos gastos públicos, não foi possível superar a característica que delineia as responsabilidades compartilhadas entre Estado e famílias na provisão de bem-estar social aos cidadãos. O ambiente econômico hostil dos anos 1990 desapareceu, mas o familismo nas políticas sociais persistiu - mesmo com variantes agora mais complexas, por meio das características de compartilhamento, transferência e omissão. E se persistiu foi porque as condições de surgimento e manutenção de sua existência não poderiam ser explicadas apenas pelas forças econômicas.

O familismo assenta-se, agora, não mais na ausência total do Estado na responsabilidade de provisões aos cidadãos, como foi durante todo o período pré-Constituição de 1988 e nos anos de chumbo do neoliberalismo, nos anos 1990. O familismo adentra o funcionamento das políticas sociais e metamorfoseia-se na formulação de suas bases. Ele não é mais o oposto do Estado interventor, mas uma das condições de existência das políticas sociais contemporâneas no Estado capitalista. Do interior do funcionamento dessas políticas, de modo geral, e da assistência social, de modo particular, é que surgem os entrelaçamentos e as relações sutis, mas precisas, entre os entes responsáveis pela manutenção das ações de proteção social. O familismo deixa de ser o reflexo da ausência do Estado para se emoldurar em um prisma complexo de políticas sociais que dependem da presença da família. $\mathrm{O}$ 
familismo não é mais apenas um espírito conservador que orienta as políticas sociais; na verdade, ele emerge e se sustenta em um circuito complexo de avanços e retrocessos na expansão da política de assistência social atual.

As políticas sociais passam a se estruturar em um circuito familista em que momentos complexos inter-relacionados possibilitam ao Estado manobrar sua participação na execução da assistência social, ora compartilhando, ora sendo omisso, ora transferindo para as famílias a capacidade de atendimento integral das necessidades dos cidadãos. $\mathrm{O}$ circuito familista permitiu a emergência de uma característica absolutamente nova para as ações de assistência social nos anos 2000: a rede de proteção social no Brasil ampliou-se, a partir de 2004, em função da condição familista. A proteção social com o familismo decorre: 1. da ausência total de ações públicas para a ação integral das famílias nas provisões de necessidades, 2. de ações parciais para responsabilidades compartilhadas entre Estado e família e 3. da transferência de responsabilidade do Estado para as famílias ou para outras instituições da sociedade civil que oferecem bem-estar, dada a fragilidade da concepção da política social como ação que protege a dignidade humana. A diferença no circuito familista é que as provisões nunca são atendidas pela atuação isolada das famílias: de um extremo ao outro, são atendidas por um encadeamento de possibilidades em que a família está presente em todas as fases, com intensidades distintas nas sobreposições de papéis com o Estado. Dessa forma, a assistência social torna-se direito de seguridade social, mas nos limites da prática estatal, que necessita da família ora para compartilhar, ora para assumir a provisão de bem-estar social dos indivíduos. Foi o familismo que permitiu a expansão da política de assistência social, nos últimos dez anos, como política de seguridade social. Sem ele, a política de assistência social continuaria limitada na sua cobertura e dividindo-se com as práticas de caridade o papel de proteção social. As consequências dessa complexa engenharia continuam sendo os obstáculos à expansão das forças de proteção social capazes de elevar o patamar de cidadania dos indivíduos e de suas famílias por meio de ações públicas que primam pelo princípio da dignidade humana.

O perfil de política de assistência social resultante do circuito familista não é um tipo de política social que guarda intacta a origem restritiva de atuação do Estado no papel de provisão das necessidades sociais desde os idos dos séculos XVIII e XIX. Pelo contrário. A consequência para a política de assistência social do circuito familista é que, agora, a política social não resulta somente da inoperância do Estado, mas da relação complexa entre política pública contemporânea e atuação parcial ou integral das famílias para garantir proteção social. 
O método genealógico aqui empregado para recuperar os trajetos por meio dos quais o familismo ainda hoje se sustenta nada teve a ver com o objetivo de descortinar a essência do familismo, seu motor central, seu espírito motivador, sua força motriz, ou qualquer outra expressão que retrate o modus operandi matricial do familismo na política de assistência social atualmente. Se a genealogia aqui empregada tem algum mérito é o de explicar como, por sucessões imprevisíveis e casuais, o familismo se transformou, se fortaleceu e se atualizou. E se a genealogia aqui empregada lograr algum êxito será o de desvelar, na verdade, os desafios futuros da política de assistência social. Porque agora, metamorfoseado e emaranhado às características das políticas públicas recentes, o familismo está reatualizado, com novos desafios e exigindo novos fôlegos para esquadrinhá-lo e elucidá-lo. 


\section{A POLÍtica DE SAÚdE MENTAL E O FAMILISMO: DA REFORMA PSIQUIÁTRICA AO CIRCUITO FAMILISTA NA SAÚDE MENTAL A PARTIR DOS ANOS 2000}

O saber psiquiátrico nasceu na virada do século XVIII para o século XIX, na Europa, representando um momento de libertação para o tratamento da loucura que, antes, aprisionava os loucos em calabouços e prisões. Naquele momento, o saber psiquiátrico significou a localização da loucura entre as afecções que seriam tratadas pelo secularismo da medicina moderna, não mais ficando na dependência dos discursos religiosos e místicos ou da punição voltada para a insanidade mental. A partir do século XIX, a loucura foi compreendida como resultado da produção humana, das causas externas, das paixões e ideias, por influência de fatores morais (CASTEL, 1979). O lugar destinado à loucura pela psiquiatria certamente tecnicizou os saberes que, até então, a descreviam principalmente como resultado das vontades divinas, seja como ira ou como benção. Ao mesmo tempo em que representou um avanço diante dos discursos tradicionais sobre a loucura, a psiquiatria como ramo da medicina no despertar do século XIX estava em descompasso com a medicina moderna nascente: enquanto a medicina moderna passou a se basear na etiologia (causa das doenças), na clínica (exame dos órgãos e dos sistemas) e nos estudos da anatomia, a psiquiatria fortalecia-se como saber científico tendo por base a prática tradicional da nosografia, isto é, o estudo meticuloso dos sinais exteriores, a observação dos sintomas fenomênicos e a descrição do que era aparente para intervenção da loucura como técnica de saber (CASTEL, 1979).

Esse lugar subalternizado do saber psiquiátrico entre os saberes da medicina moderna teve desdobramentos significativos para a emergência da psiquiatria como um discurso de poder e para a técnica de isolamento dos indivíduos como parte de sua terapêutica (FOUCAULT, 2006; CASTEL, 1979). Isto é, como a medicina clássica desde a Grécia até o século XVIII baseou-se na nosografia, a psiquiatria tinha tudo para não alcançar o status de saber científico por se utilizar de um paradigma, agora, considerado obsoleto dentro dos saberes biomédicos. Mesmo assim, a eficácia da psiquiatria diante dos demais saberes médicos que se atualizaram com o estudo da etiologia deveu-se, principalmente, ao uso da terapêutica baseada no isolamento e no higienismo (CASTEL, 1979). A psiquiatria foi a resposta imediata e objetiva para o tratamento moral, em um momento em que o higienismo descrevia os loucos como portadores de perigo social. Do isolamento punitivo e desumano até o século XVIII, a terapêutica asilar e manicomial foi autorizada pela técnica científica da 
psiquiatria, que necessitava da observação dos loucos nos manicômios para se fortalecer como saber técnico. Esse modelo asilar perdurou até os anos 1970 ao redor do mundo.

No Brasil, os primeiros manicômios surgiram no período imperial, em um momento de lento - mas cada vez mais intenso - processo de urbanização na segunda metade do século XIX. Se antes a loucura era assimilada pelos costumes e pelas práticas de um país camponês e agrário nos limites da proteção primária oferecida pelas famílias, com a emergência das cidades, a loucura transformou-se em questão necessária de absorção pelos poderes públicos para respostas imediatas (ENGEL, 2001). Com a urbanização, o sujeito louco não era o mero representante de um perigo social pela violência inerente a sua doença mental: era, antes, um sujeito inassimilável pelos valores sociais em torno do trabalho, apresentando comportamento distinto do esperado dos sujeitos das vilas urbanas. Era um indivíduo inapto a se sujeitar ao ideal de família burguesa produtiva, urbana e industrial que se estabelecia a partir do século XX no país. Por sua vez, como um sistema complexo, a psiquiatria de base manicomial estruturou-se na sintomatologia, na desordem social como causa da loucura, na preponderância das causas morais, no tratamento moral e, por fim, na instituição asilar. Nesse sentido, a hegemonia asilar ou manicomial conheceu o limite do seu modelo nos anos 1970, quando ficou mais evidente a ineficácia da psiquiatria asilar por meio, principalmente, do crescimento das populações manicomiais sem possibilidades de solução e de cura dos sofrimentos mentais.

Os movimentos reformistas da psiquiatria proporcionaram um amadurecimento teórico sobre a crítica ao asilamento como paradigma de atenção psiquiátrica que esteve presente em todo o século XX no país (DELGADO, 1992). A experiência italiana da desinstitucionalização psiquiátrica, iniciada nos anos 1960 e 1970, foi tomada como referência pelo movimento de reforma psiquiátrica brasileira a partir dos anos 1980. O movimento de contestação do asilamento na assistência psiquiátrica promoveu uma reflexão ampla sobre o processo de institucionalização e chegou a criar estratégias na luta antimanicomial. Essa luta culminou na Lei de Reforma Psiquiátrica, Lei n ${ }^{\circ} 10.216$, de 2001, que redefiniu os padrões de tratamento oferecido às pessoas em sofrimento mental de modo predominante em regime aberto, não asilar.

A partir dos anos 2000, a política de saúde mental brasileira buscou romper com as práticas tradicionais a respeito da assistência à loucura assentada no modelo manicomial. Para a mudança de atitude a respeito da afirmação do louco como um sujeito portador de direitos de cidadania, surgiram as demais possibilidades de ruptura com práticas tradicionais de tutela 
e assistência em saúde àqueles com doenças e transtornos mentais. A estruturação da lógica manicomial como hegemônica no Brasil durante quase 150 anos, com o início em meados do século XIX, deixou marcas profundas e difíceis de serem superadas a partir dos anos 2000, quando as políticas sociais que buscavam materializar direitos sociais básicos passaram a ser baseadas em novos princípios e práticas institucionais. Revigorada pela mudança jurídica e principiológica introduzida pela Lei da Reforma Psiquiátrica, em 2001, a política de saúde mental enfrentou ainda entraves para o desenvolvimento da assistência em saúde mental por esbarrar em uma estrutura limitada do Estado responsável por desinstitucionalizar a assistência em saúde mental centrada nos manicômios.

Como demonstrado no capítulo anterior, a estruturação de políticas sociais ao longo dos anos 1990 e 2000 baseou-se em novos paradigmas orientadores da atuação do Estado no que diz respeito à provisão das necessidades sociais, como os princípios constitucionais inaugurados em 1988. Apesar disso, as políticas sociais continuaram sendo arena de contradições inerentes ao Estado capitalista (PEREIRA, 2014). Dessas contradições derivaram continuidades com práticas tradicionais relativas ao alcance e perfil das políticas sociais, como a presença do familismo na política de assistência social mesmo quando ela se reorganizou com o objetivo de materializar direitos de cidadania. Ainda a partir dos anos 2000, a assistência social enfrentou reveses quanto às atuações tradicionais do Estado, que não assumiu, de forma comprometida com os princípios democráticos e republicanos, sua responsabilidade na consecução de políticas sociais universais.

Com a política de saúde mental, não seria diferente. Para superar a hegemonia do modelo manicomial na atenção em saúde mental, a reforma psiquiátrica assumiu o tripé "família, trabalho e comunidade" (parágrafo único, do artigo $2^{\circ}$ ) como locus privilegiado para estruturar os serviços substitutivos de saúde mental no país (BRASIL, 2001). No entanto, esse tripé, que conta com a participação da família como ente responsável nesse novo modelo de atenção à saúde mental, pode trazer consequências deletérias para o escopo da política de saúde mental no cenário atual.

Nesse sentido, o objetivo deste capítulo é explorar, por meio do método genealógico, em que medida o familismo esteve presente no modelo manicomial de atenção à saúde desde meados do século XIX e persistiu nas políticas e ações da saúde mental a partir de 2001. Será verificado, também, como tais ações interferem contemporaneamente no processo de fortalecimento do paradigma não asilar como alternativa na assistência em saúde oferecida aos indivíduos com doenças e transtornos mentais. Desse modo, o argumento defendido no 
capítulo será o de que o amadurecimento dos serviços substitutivos em saúde mental como alternativos ao paradigma asilar e manicomial ocorreu porque tal responsabilidade do Estado perante as políticas públicas foi compartilhada com as famílias. De forma mais intensa que a política de assistência social, o familismo nos serviços substitutivos de saúde mental em meio aberto foi a condição de possibilidade para a superação do modelo manicomial. Portanto, as políticas de assistência social e de saúde mental expressam ainda vários traços do passado, como o papel preponderante das famílias na provisão de bem-estar dos indivíduos, o que pode impedir que tais ações se desenvolvam ao ponto de cobrir todos os casos para os quais as ações públicas foram criadas, principalmente, no que diz respeito aos objetivos desta tese, para os casos dos indivíduos em sofrimento mental que cumprem medida de segurança.

\subsection{O nascimento dos asilos: a questão da loucura como caso de polícia e de tutela asilar}

O século XIX no Brasil é emblemático sob vários aspectos. Em primeiro lugar, o país enfrentou um processo de transição populacional da zona rural para a urbana para a qual a estrutura burocrática da administração pública do período imperial não estava preparada. Era nítida a falta de sensibilidade institucional para alguns casos que impunham desafios à administração imperial herdada dos limites institucionais da administração portuguesa do Período Colonial: o Brasil era um país de território continental e a falta de centralidade da administração pública dispersava, nos limites territoriais, muitos dos problemas sociais importantes de serem enfrentados (FAUSTO, 2001). A pobreza das famílias, o desemprego, as precárias condições de trabalho e emprego nos universos rurais ou urbanos, o longo período da escravidão e a falta de segurança nacional — ocasionando conflitos perenes e com constantes ameaças de invasão estrangeira —-, além das condições aviltantes de saúde de grande parte da população, eram os principais temas a que a administração pública precisava se dedicar (COSTA, 1979). Em segundo lugar, o crescimento das vilas urbanas, somado ao crescimento populacional e ao lento processo de substituição da mão de obra escrava pelo regime liberal de contratação de força de trabalho, no final do século XIX, teve impactos consideráveis para muitas problemáticas sociais, retardadas em suas soluções devido às contradições de uma sociedade estruturada segundo o modo de produção capitalista em um país periférico na organização do capital internacional.

Desse modo, em meados do século XIX, o tema da loucura começou a despertar o interesse público. A sociedade brasileira estava intensamente dividida em dois grupos sociais: uma minoria de senhores e proprietários e uma maioria esmagadora de escravos e de 
inadaptados sociais, que seriam aqueles sem trabalho definido ou totalmente sem trabalho. Havia um grupo consistente e numeroso de desocupados nas ruas das cidades e no campo, o qual seria ainda aumentado pelos insanos que, indisfarçáveis, eram acoplados à rede comum de repressão à desordem, mendicância e ociosidade (RESENDE, 1997). Isso estabelecia no imaginário social a ideia de que a loucura trazia medo e risco à paz social, ameaçando principalmente a Corte e a população branca e proprietária. Até então, não havia perturbações sociais pelo contato com a insanidade mental. A partir daquele momento, as enfermarias das Santas Casas de Misericórdia constituiriam a alternativa às prisões, em razão da inconveniência da livre circulação do louco nas ruas.

Aos poucos, o tema da loucura começou a encontrar espaço naquele turbulento desenrolar do século XIX para receber atenção da administração pública. Não muito diferente dos países europeus, a loucura tornou-se problemática social nos limites da redescrição das pessoas portadoras de doenças mentais como perigos sociais que demandavam respostas apropriadas do poder público. As primeiras iniciativas de formulação de uma instituição capaz de atender às necessidades dos indivíduos com doenças mentais surgiram, como não podia deixar de ser, na capital do Império, a cidade do Rio de Janeiro, em 1852 (DELGADO, 1992). O Hospício D. Pedro II ensejaria uma resposta aos loucos não apenas no sentido da assistência necessária aos desamparados que experimentavam uma enfermidade mental. A assistência aos loucos cunhada pelos hospícios era, antes de mais nada, uma tutela para os indivíduos inassimiláveis pela sociedade nascente baseada na urbanização, no trabalho livre cada vez mais substituto ao regime de escravidão e, principalmente, no cuidado voltado para os indivíduos desfamiliarizados ou para aqueles cuja relação com a família fosse fragilizada (ENGEL, 2001). Principalmente, antes de uma resposta de um equipamento público de saúde, os hospícios eram uma resposta à situação de pobreza e desajuste de indivíduos com algum transtorno e doença mental que representavam um perigo iminente para os demais indivíduos, para as famílias e para a sociedade. Até porque a assistência médica era limitadíssima, pois a terapêutica de então era baseada tão somente em sangrias e sedenhos, quando não em exorcismos católicos e fetichistas (MOREIRA; PEIXOTO, 2001). Restava à assistência médica mais a prática da tutela do que procedimentos de atenção em saúde.

Na Europa, a psiquiatria alienista nascida nos idos do século XIX com Phillipe Pinel enfrentara desafios a respeito de sua subalternidade como ramo da medicina moderna pelo uso da já obsoleta nosografia (CASTEL, 1979). Enquanto isso, no Brasil, os hospícios emaranhavam-se com desafios relacionados a outro legado: os equipamentos públicos eram 
incipientes em um país cuja estrutura burocrática da administração pública dava os primeiros passos rumo a respostas mais articuladas do poder público às necessidades sociais. A soma entre psiquiatria rudimentar e políticas públicas frágeis resultou na estruturação de uma psiquiatria do isolamento talvez ainda mais significativa que aquela acompanhada no território europeu. Não é que a eficácia da administração pública seria responsável por salvar o discurso psiquiátrico dos perigos do enclausuramento. No entanto, na medida em que o poder público encontrou dificuldades na estruturação de equipamentos públicos adequados, a tutela intensificou a restrição de liberdade indevida em meio a condições precárias de assistência.

A inauguração do Hospício Pedro II alavancou uma sequência de construções de hospícios nas principais cidades brasileiras. O Hospício Provisório de Alienados, em São Paulo, que iniciou seu funcionamento também em 1852, numa casa alugada, apenas depois de 1860 passou a ter atendimento médico (ENGEL, 2001). Em 1861, a superlotação gerou mudança no local do hospício, que foi seguida por nova superlotação no Hospício de Alienados de Sorocaba. Posteriormente, em 1898, o Hospício de Juquery estabeleceu-se como principal estabelecimento psiquiátrico do estado de São Paulo. Em Recife, em 1874 foi construído o Hospício de Alienados da Tamarineira. Outros estabelecimentos foram criados em vários municípios, como o Asilo de Alienados no Pará, em 1873, e o Asilo de S. João de Deus na Bahia, em 1858. Em 1903, foram criados dois dos mais importantes manicômios brasileiros, o Hospício São Pedro, no Rio Grande do Sul, e o Hospital Colônia de Barbacena, no interior de Minas Gerais (ENGEL, 2001).

Muitos estudos demonstram o quanto o perfil das primeiras populações dos manicômios brasileiros tem mais a ver com problemáticas sociais, como pobreza, desemprego, alcoolismo, prostituição e abandono familiar, do que propriamente com necessidades de assistência médica (ENGEL, 2001; MACHADO et al., 1978). No século XIX e em grande parte do século XX, a psiquiatria não encontraria como seu sujeito ideal puro apenas o sujeito louco. Em meio a um conjunto de problemáticas sociais, a loucura somatizava várias delas e a resposta do manicômio não seria nem para as problemáticas sociais, no sentido do atendimento das necessidades, nem puramente para a assistência médica. A psiquiatria passou a significar o imperativo da busca por respostas às necessidades dos sujeitos enclausurados que, pela ausência de articulação entre esse imperativo e o ordenamento jurídico vigente, resultaria em uma tutela mais prejudicial, por seu caráter punitivo, do que propensa à garantia das necessidades dos indivíduos. Dessa contradição, 
emergiu um modelo de assistência aos indivíduos com doenças e transtornos mentais que, somente com a Lei 10.216 , de 2001, teria relação mais imbricada entre prática assistencial e proteção da cidadania (DELGADO, 1992).

Até fins do século XIX, o cenário econômico e político não era favorável à superação desse hibridismo do modelo manicomial brasileiro. Pelo contrário. As forças econômicas e políticas potencializaram essa particularidade do modelo manicomial, cujas respostas ultrapassaram os limites de oferecer apenas assistência médica aos indivíduos em sofrimento mental. Durante o século XX, o processo de urbanização mais intenso e a industrialização, contribuindo para novas forças econômicas internas no Brasil e a introdução dos princípios republicanos, alteraram o escopo das responsabilidades estatais quanto às necessidades dos loucos. Em 1903, foi publicado o Decreto 1.132, a Lei de Assistência aos Loucos, que reorganizou e embasou as políticas de assistência aos loucos nos anos subsequentes, no país já republicano (BRASIL, 1903). Até aquele momento, como a técnica da psiquiatria asilar pouco oferecia respostas terapêuticas para a cura das doenças mentais, muito do saber psiquiátrico ficou dependente da assistência às necessidades sociais colocadas por aqueles que experimentavam algum tipo de sofrimento mental. Isto é, a eficácia da psiquiatria passaria a ser medida menos pelo que ela restabelecia de cura e mais pelo que oferecia - como efeito colateral — de assistência às necessidades sociais.

O Decreto 1.132, de 1903, introduziu pelo menos três novidades no sistema de assistência a alienados no Brasil. A primeira delas foi estabelecida no artigo $1^{\text {o: }}$ "o indivíduo que, por moléstia mental, congênita ou adquirida, comprometer a ordem pública ou a segurança das pessoas, será recolhido a um estabelecimento de alienados" (BRASIL, 1903). A perspectiva da lei de assistência a alienados assentava-se primordialmente na lógica da proteção dos indivíduos e da sociedade do perigo representado pela loucura, e não na necessária assistência médica a ser oferecida aos indivíduos. Essa tônica esteve presente em todo o século XX no país, como diretriz que demarcava os motivos da internação.

Em segundo lugar, a internação nos asilos foi possível a pedido de particulares, como assinalado no artigo $2^{\circ}$ : "a admissão nos asylos de alienados far-se-há mediante requisição ou requerimento, conforme a reclame autoridade pública ou algum particular" (BRASIL, 1903). A possibilidade de admissão nos asilos manicomiais a pedido de particular e não somente das autoridades públicas deu início ao processo de internação a pedido das famílias e estabeleceu um conjunto complexo e articulado no circuito entre família, Estado e manicômio para oferecer assistência aos doentes mentais. 
Por fim, no artigo $3^{\circ}$, ficou estabelecido que “o enfermo de alienação mental poderá ser tratado em domicílio, sempre que lhe forem subministrados os cuidados necessários" (BRASIL, 1903). Em seguida, no parágrafo único do referido artigo, o decreto deixou claro que, se a moléstia mental ultrapassasse dois meses, a família informaria a autoridade para as necessárias providências. Desse modo, ora como uma responsabilidade compartilhada com as famílias, ora como tema mais de segurança pública do que de saúde, nascia a assistência a alienados no Brasil, no limiar do século XX, já se baseando, de forma limitada, nos princípios republicanos.

No entanto, foi com a promulgação do Decreto 24.558, de 1934, que o papel das famílias na internação dos indivíduos nos manicômios ganhou força, principalmente por dois artigos da lei, o $11^{\circ}$ e o $21^{\circ}$ (BRITTO, 2004). No artigo $11^{\circ}$, ficou estabelecida a solicitação de internação de psicopatas, toxicômanos e intoxicados habituais. Determinou-se que tal procedimento poderia ser feito por autoridade pública (ordem judicial ou requisição policial) ou por qualquer outra pessoa interessada, "desde que seja declarada a natureza de suas relações com o doente e as razões determinantes da sua solicitação" (BRASIL, 1934). Já o artigo $21^{\circ}$ estabeleceu as normas para a retirada do interno de um estabelecimento psiquiátrico. A saída "não será recusada [...] em qualquer estabelecimento quando requerida a) pela pessoa que pediu a internação, b) por cônjuge, pai ou filho ou outro parente de maioridade até o $4^{\circ}$ grau inclusive, na falta daqueles e c) por curador ou tutor" (BRASIL, 1934). O procedimento da alta passou a envolver um rigoroso controle exercido por diversas instâncias, como família, Comissão Inspetora, juiz e direção do estabelecimento, o que ressaltava a periculosidade da pessoa internada (BRITTO, 2004). Passados mais de 70 anos, principalmente com a promulgação do Código Penal de 1940, essa relação intricada entre assistência, segurança pública, sistema de justiça e família, no momento da desinternação do louco, oferece o grande modelo do circuito familista na política de saúde mental, que perdura até os dias de hoje no Brasil. Esse modelo, também exportado para os casos dos indivíduos em medida de segurança, será analisado detalhadamente no sexto capítulo.

O tema das necessidades sociais como demandas a serem atendidas pelos poderes públicos caminhava de forma lenta rumo à cristalização dessa responsabilidade como da alçada da administração pública sob a batuta do Estado. A pobreza e as demais situações de privação social decorrentes dela eram tratadas predominantemente na esfera das questões de polícia. Pobreza, desemprego, analfabetismo, desnutrição, precárias condições de moradia, trabalho e saúde não eram temas que a administração pública do Império tratava na esfera dos 
aperfeiçoamentos contínuos buscados por intervenções do poder público. A questão social como caso de polícia ia ao encontro das narrativas de transformações ensejadas pela sociedade brasileira daquele período.

Era preciso forjar o ideal do trabalho como valor central de uma sociedade que saía do modelo escravocrata, e isso ocorria, sobretudo, por meio da punição à vagabundagem. Era necessário também tratar as questões de saúde como prerrogativas e mudanças necessárias dos hábitos das famílias em termos de higiene e cuidado dos filhos, e não como uma ação coletiva dos poderes públicos (COSTA, 1979). Por outro lado, as questões de pobreza e desemprego eram vistas como problemas superficiais que, na maioria das vezes, eram mais de responsabilidade individual, resultado do esforço insuficiente dos indivíduos para saírem de tais situações, do que uma problemática a ser enfrentada pelos poderes públicos. Diante desse quadro, a terapêutica dos manicômios se via em um descompasso pela prática da assistência em um momento em que ela ainda não havia sido localizada na perspectiva dos direitos das pessoas a viverem livres das privações advindas do sofrimento mental.

Nesse sentido, tão ou mais importante do que as bases que estruturariam a assistência aos loucos até o final dos anos 1980 de forma hegemônica no modelo manicomial foi o modelo de cidadania estabelecido no Brasil por meio da proteção aos trabalhadores a partir dos anos 1920 (SANTOS, 1979). Como salientado no capítulo anterior, a proteção social para amenizar as condições de vida dos trabalhadores e a emergência de inúmeros direitos trabalhistas com a criação da Lei Eloy Chaves, em 1923, deu início à construção das plataformas do que seria a cidadania social como responsabilidade dos poderes públicos (SANTOS, 1979). Embora a ampliação limitada da cidadania até a Constituição Federal de 1988 tenha se devido, principalmente, a esse modelo que restringia aos trabalhadores o status de cidadania social, as consequências para a assistência médica aos indivíduos com doenças e transtornos mentais foram imediatas. $\mathrm{O}$ acesso aos serviços de saúde na perspectiva ampliada (na medida do possível), por meio da assistência médica e hospitalar, estava também restrito ao universo dos trabalhadores e seus dependentes: não existia a saúde como política pública e direito de cidadania. $\mathrm{O}$ acesso à saúde era, na verdade, uma espécie de direito trabalhista e, no máximo, a população pobre tinha acesso à saúde oferecida pelas Santas Casas de Misericórdia. Essa inconsistência da política de saúde durante o século XX, em meio à hegemonia do modelo manicomial de atenção àqueles em sofrimento mental, provocou uma cisão da assistência médica nos casos de doença mental na perspectiva da cidadania. Certamente, essa alegação poderia ser estendida a todos os demais casos que demandavam 
atenção em saúde. Na saúde mental, o que esse modelo intensificou nessa cisão foi exatamente o fato de que a assistência em saúde mental, no modelo manicomial, é estruturada mais numa perspectiva de punição do que de atendimento das necessidades em saúde.

De um lado, os tratamentos em saúde mental eram precários e, mesmo com o advento dos medicamentos psicotrópicos, nos anos 1930, pouco avanço ocorreu no aperfeiçoamento das práticas terapêuticas para as doenças mentais. Por outro lado, causa e consequência da inadequação do sujeito louco às expectativas sociais e morais a respeito do sujeito produtivo em uma sociedade que preza o trabalho, a apartação do meio social promovida pelo modelo manicomial impactou o estabelecimento de proteção social aos indivíduos em sofrimento mental. Quanto maior a dependência do modelo manicomial como única alternativa de assistência para os doentes mentais, maiores seriam os desafios de inserção social no mundo do trabalho, da comunidade e da família. Enquanto o modelo de assistência à saúde mental continuasse na dependência manicomial, os desafios do exercício da cidadania na loucura seriam prejudicados.

Tratamentos precários, desproteção social e tutela punitiva aos doentes mentais acabaram por destinar às famílias uma corresponsabilidade pela proteção àqueles em sofrimento mental. Como origem do circuito familista no caso da saúde mental, houve em 1934 um impulso nas regras que permitiam a internação psiquiátrica: antes, ela era atribuição da autoridade imperial, e depois, com o advento da República, de especialistas. De repente, a partir dos primeiros anos do século XX, a família ganhou também poder de decisão para internação dos indivíduos loucos. Nos limites das relações imbricadas entre indivíduo, família, instituição asilar e Estado, a prerrogativa da internação como da alçada das famílias passou a representar um curioso binômio entre Estado e família no papel de poder, vigilância e controle sobre os indivíduos em sofrimento mental. Pela primeira vez, a família não só proveria as necessidades sociais dos indivíduos loucos pela ausência do Estado, mas também ofereceria os indivíduos loucos à engrenagem das instituições psiquiátricas e punitivas, no modelo manicomial.

Essa mudança não teria maiores impactos se as políticas sociais de proteção aos indivíduos cumprissem suas prerrogativas de atendimento às necessidades sociais. Mas não foi isso que se percebeu ao longo do século XX. Contrariamente, as contradições inerentes à sociedade brasileira, inseridas no marco da divisão internacional do trabalho e do capitalismo periférico e dependente das forças internacionais, teve influência direta no lento processo de assimilação, por parte dos poderes públicos, das demandas sociais prementes. A atenção aos 
trabalhadores que obtinham proteção social pelas vinculações ao sistema de previdência social, as privações atendidas pelas instituições de caridade e filantropia e todo o universo de desproteção dos demais indivíduos provocaram o constante aprofundamento das mazelas e das precárias situações socioeconômicas da população brasileira. Foi para essa situação cada vez mais emergente que, apenas durante o processo de reabertura democrática brasileiro, na década de 1980, o país ofereceu respostas encontradas em um ambiente mais propício ao estabelecimento de novas bases para a conformação da cidadania ampliada.

\subsection{Assistência como filantropia e punição como assistência: paradoxos nas definições da razão de Estado brasileiro no século $X X$}

O século XIX lançou as bases para a assistência aos alienados que perduraria até o início do século XXI no país. Durante o século XX, relações paradoxais estiveram presentes na assistência pública (tanto médica quanto social) oferecida aos sujeitos acometidos de enfermidades mentais. Longe dos limites da compreensão do louco como detentor de direitos de cidadania, a loucura representava essencialmente um perigo às famílias e à sociedade, e essa decodificação da loucura como perigo deu origem a um tipo peculiar de assistência: a assistência tutelar punitiva. A emergência da institucionalização para punição da loucura não dependeu apenas da estruturação de equipamentos públicos para responder aos loucos que perambulavam pelas ruas das cidades cada vez mais dinâmicas. A institucionalização estava também na base da resposta técnico-científica da psiquiatria, sendo a intensificação do isolamento resultado do complexo somatório que isolava não apenas para punir, mas também para cumprir com a promessa da cura.

Entre os princípios que organizavam o espaço e a vida asilar, o isolamento era o traço fundamental. Proposto em textos do médico francês Esquirol, ele compunha a literatura psiquiátrica brasileira em importantes teses de doutorado e outros textos da área médica em meados do século XIX (MACHADO et al., 1978). Separar o louco da sociedade tinha o objetivo de afastá-lo dos elementos causadores da loucura, que estariam presentes nas relações sociais e na família. Desse modo, o hospício reorganizaria o contato entre doente e família, tornando o sujeito novamente capaz de conviver no interior das famílias (FOUCAULT, 2006). Os médicos postulavam que a presença de amigos e parentes estaria relacionada às causas da loucura, pois provocaria as violências e irrupções da loucura. $\mathrm{O}$ alienista defendia e protegia a família, além de romper com os hábitos do louco. 
Pelas contradições dos princípios basilares do alienismo, o isolamento não era indicado para todos os tipos de louco, mas para um tipo específico: aquele oriundo de família pobre e com o hábito de perambular pelas ruas (SOARES, 2006). Os loucos de famílias ricas poderiam ser mantidos em casa, ainda que lá houvesse limitações para o seu tratamento. Essa teoria estaria pautada no princípio de que a riqueza poderia oferecer garantias quanto à segurança e ao tratamento (SOARES, 2006). A possibilidade de intervenção terapêutica por meio do isolamento apresentava-se como item importante no regime médico e policial dos hospícios e guardava uma característica singular com o complexo assistencial montado: o modelo manicomial introduziu um traço definidor nas políticas públicas e na responsabilidade do Estado pelas provisões dos doentes mentais - a punição da pobreza antes de qualquer outra profilaxia sobre a problemática da loucura.

Esse modelo representou uma tragédia para a proteção dos direitos dos indivíduos loucos. Até mesmo no trabalho exercido no interior dos manicômios havia diferenciação entre os loucos ricos e os loucos pobres. Como aponta Ilka Soares (2006), aos pobres, caberia a atuação em oficinas, jardins e serviços do hospício. Aos ricos, as diversões: jogos e biblioteca. Sob o argumento de que o hospício espelha a sociedade, esses critérios deveriam ser cumpridos. Eram inúmeras as contradições da sociedade brasileira nas primeiras décadas do século XX que reforçavam, no interior dos hospícios, as características que embasavam a sociedade. No entanto, o isolamento nunca fora algo apenas negativo, nefasto, diante do insulamento em relação à sociedade. Ao contrário, a eficácia do isolamento no modelo manicomial residiu justamente naquilo que ele tinha de produtivo, positivo e eficiente para as expectativas da sociedade (FOUCAULT, 2003a). O isolamento não seria prejudicial se voltado apenas ao funcionamento dele mesmo: o isolamento do manicômio precisa buscar sustentação em princípios e valores externos ao manicômio.

Quais seriam as justificações positivas para o modelo manicomial, em contraste às consequências negativas do isolamento em um país que começava a se modernizar, nos anos 1930? As principais sustentações do modelo de apartamento pela lógica manicomial tinham relação com o papel das famílias e do Estado. Isto é, o isolamento, tido como insustentável somente a partir do final dos anos 1970, tanto na Europa quanto no Brasil, apoiou-se durante quase dois séculos naquilo que trazia de cimento e base estrutural à sociedade, o que permitiu à assistência médica assentar-se sobre tais procedimentos. No caso brasileiro, parte dessa conjectura tem a ver com o papel que a administração pública assumiu como aspiração à necessária modernização do Estado brasileiro, sobretudo a partir dos anos 1930. Sérgio 
Buarque de Holanda (1995) busca explicitar as bases de sustentação do Estado brasileiro que nascia após os anos 1930 e estabelecer os desafios colocados à superação do patrimonialismo nas relações no interior das estruturas estatais. Para ele, só raramente houve no país um modelo administrativo que levasse em consideração a impessoalidade, os princípios republicanos e os valores abstratos da burocracia moderna, pois predominavam vontades particulares em círculos fechados e pouco sensíveis às ordenações impessoais dos valores coletivos. Segundo Holanda,

dentre esses círculos, foi sem dúvida o da família aquele que se exprimiu com mais força e desenvoltura em nossa sociedade. E um dos efeitos decisivos da supremacia incontestável, absorvente, do núcleo familiar - a esfera, por excelência dos chamados "contatos primários", dos laços de sangue e de coração - está em que as relações que se criam na vida doméstica sempre forneceram o modelo obrigatório de qualquer composição social entre nós. Isso ocorre mesmo onde as instituições democráticas, fundadas em princípios neutros e abstratos, pretendem assentar a sociedade em normas antiparticularistas (1995, p. 146).

É possível afirmar que o modelo de relação no interior da administração do Estado no Brasil no século XX pouco entronizou dos valores coletivos e dos princípios republicanos. Mesmo a partir dos anos 1930, com um processo mais acelerado de burocratização do Estado mediante a revolução introduzida por Getúlio Vargas, o patrimonialismo, ou seja, o uso dos aparelhos do Estado em favor de interesses individuais, não deu lugar de forma automática aos valores republicados que representavam os valores coletivos. Não seria diferente com a política de assistência a alienados baseada na punição e no isolamento. O patrimonialismo é o traço marcante de uma sociedade antiga que tenta sobreviver e se reinventar. Seguindo Holanda (1995), a matriz formadora do Estado brasileiro é a moral da família, ou a ética de Antígona, em que os deveres e as lealdades de sangue se sobrepõem às do Estado republicano.

O tratamento desigual entre loucos pobres e loucos ricos nos hospícios e a emergência de um modelo que segregava para o tratamento, mesmo quando os ricos podiam ser tratados nos domicílios, só encontrou sustentação em uma sociedade ainda sem a matriz capaz de orientar suas ações baseadas nos valores individuais e jurídicos que estruturavam a república e a democracia. Se o patrimonialismo é o braço do arcaísmo na burocracia moderna, o asilamento se escorava em valores frágeis cujas relações sociais entre Estado e família não alcançaram a máxima dos interesses coletivos. Isto é, análogo ao patrimonialismo, o papel do Estado na sua relação com as famílias dos loucos apenas reinventava práticas tradicionais de tutela e simulacro de princípios familistas nos asilos. O asilamento sustentava-se, sobretudo, 
porque encontrava tanto na família quanto no Estado relações que não levavam a sério a transição republicana.

Desse modo, a tutela asilar surgia como assistência integral aos loucos em um momento em que a assistência aos indivíduos era baseada essencialmente na filantropia e na caridade das instituições religiosas. A assistência integral aos indivíduos não se dava em razão da visão a respeito de uma demanda a que o Estado tinha de atender, como passou a ser com a Constituição Cidadã e com a Lei da Reforma Psiquiátrica (BRASIL, 1988, 2001). Contrariamente, era a representação máxima da negação do sujeito louco como detentor de direitos de cidadania (DELGADO, 1992). O louco tutelado era resultado da negação desse sujeito e de sua sociabilidade. Para essa negação, apenas uma instituição que pudesse oferecer nos limites de seus muros tudo de que o indivíduo louco necessitava em seu cotidiano teria legitimidade política, institucional e social diante das demandas públicas e da família. A promessa de assistência integral no regime asilar era o grande aspecto positivo que fazia com que o modelo manicomial se sustentasse, entre meados do século XIX e as últimas duas décadas do século XX, como única alternativa para assistência aos doentes mentais.

Não é forçoso afirmar isso se, ao prestar atenção à rede de saúde mental e à rede de assistência pública no Brasil naquele período, verifica-se que ambas eram refratárias a qualquer possibilidade de provisão àqueles em sofrimento mental na perspectiva da promoção da autonomia dos sujeitos para incluí-los na sociedade e na família. A saúde era devida aos trabalhadores ou oferecida pelas Santas Casas de Misericórdia, que, desde meados do século XIX, também já não atendiam os loucos, em razão da criação dos hospícios. Por outro lado, a assistência social de modo fragmentado, disperso e ilegítimo como ação capitaneada pelos poderes públicos só iria se estruturar de forma limitada após a Segunda Guerra Mundial, com a criação da Legião Brasileira de Assistência, na década de 1940, como analisado no capítulo anterior. Desse modo, não era inteligível a prerrogativa de o Estado oferecer assistência para provisão das necessidades sociais dos indivíduos em sofrimento mental que não fosse pelos manicômios existentes em todo o território nacional.

O modelo manicomial sustentou-se porque a razão de Estado, na perspectiva moderna e iluminista, não se instalava no país. A razão de Estado ainda flutuava entre princípios monárquicos e valores republicanos, respondendo a pequenos grupos que acomodavam seus interesses particulares no interior da administração pública. Nos termos de Foucault (2008), o Estado brasileiro ainda não havia se governamentalizado, isto é, não tinha adquirido a razão de Estado sob os aspectos modernos e contemporâneos. Para ele, "a soberania se exerce nos 
limites de um território, a disciplina se exerce sobre os corpos dos indivíduos, e, por fim, a segurança se exerce sobre o conjunto de uma população" (FOUCAULT, 2008, p. 16). Assim a formação das cidades e o saber da economia e da ciência política engendrariam as forças de que o Estado precisava para atuar na sociedade. Governamentalidade como razão de Estado busca atingir o problema da sociedade civil e levar o saber técnico-científico para embasar suas tomadas de decisão cotidianas, além de atuar de forma primordial na condução da economia e segurança das populações e estabelecer os sistemas complexos das garantias jurídicas e políticas à liberdade (FOUCAULT, 2008). Para recepcionar esses objetivos como razões de Estado, o caso brasileiro ainda enfrentaria vários desafios no século XX.

Não é de assalto que o Estado assume funções por meio da governamentalidade que, há anos, eram de responsabilidade dos interesses particulares e das famílias na atenção aos sujeitos loucos. Segundo Foucault, "podemos fazer a genealogia do Estado moderno e dos seus diferentes aparelhos a partir de uma história da razão governamental” (2008, p. 476). Lento seria o processo pelo qual o Estado se modernizaria para a transição do patrimonialismo para um regime republicano que representasse os interesses coletivos da sociedade - projeto de sociedade ainda hoje inacabado. O patrimonialismo está para as atribuições da administração pública assim como o familismo está para as políticas sociais do Estado, que ainda compartilha com as famílias a responsabilidade de provisão de bem-estar dos cidadãos. Não é de repente que o Estado se moderniza com os princípios seculares, republicanos, laicos e democráticos para orientar suas ações. Registrar esse lento processo não tem o objetivo de afirmar o quão distante o presente factível está do passado tão inquestionavelmente prejudicial às práticas da administração pública. Destarte, esta análise visa assinalar que a natureza das ações públicas do presente guarda relação com princípios do passado, embora tal natureza esteja modificada e aperfeiçoada pelo que se consegue captar de suas aparências atuais.

\subsection{Acesso universal à saúde e reforma psiquiátrica: o paradigma da cidadania}

Como elucidar que a problemática da loucura apresentava várias limitações no padrão de assistência oferecida aos indivíduos em sofrimento mental se contrastada às razões de Estado que a administração pública brasileira deveria adquirir? Além disso, sobre quais bases o modelo asilar se ergueu e se aparou durante quase 150 anos, mesmo representando as limitações relacionadas ao desrespeito a direitos dos indivíduos no interior dos asilos? As duas perguntas somente podem ser respondidas analisando-se o cenário político, institucional 
e jurídico no qual a hegemonia manicomial circunscrevia a problemática da assistência aos loucos. Se se obteve um modelo técnico-científico baseado em um paradigma obsoleto na medicina praticada na Europa, é difícil pressupor que essa barreira levaria a tão longe o poder psiquiátrico baseado na terapêutica do isolamento. A hegemonia asilar foi muito longe no Brasil porque era legitimada por parte importante do imaginário social, pelas expectativas das famílias e por ações do poder público. Tal afirmação precisa ser decodificada e requer atenção ao padrão das políticas sociais estruturado no Brasil ao longo do século XX - padrão este que seria questionado no período da reabertura democrática do país, depois de mais de duas décadas do regime militar iniciado com o golpe militar de 1964.

$\mathrm{Na}$ esteira dos movimentos contestatórios que enfraqueceram o regime militar na virada dos anos 1970 para os 1980, o Movimento da Reforma Sanitária foi crucial para estabelecer novas bases sobre as quais o Estado se relacionaria com as demandas da população por assistência à saúde na perspectiva dos direitos universais a todos os cidadãos brasileiros. Mais do que um projeto de sistema de saúde, o Movimento da Reforma Sanitária visava a um projeto de sociedade, plural, participativa e capaz de influenciar nos rumos não só da política de saúde como do sistema nacional, oferecendo um molde para todas as políticas públicas que o Estado encamparia a partir de então (GERSCHMAN, 2004). Desse modo, mais do que definir o escopo da política de saúde, o Movimento da Reforma Sanitária, ao lutar pela saúde como direito de todos e responsabilidade do Estado, estabeleceu as diretrizes para várias das políticas sociais a serem assinaladas na Constituição Federal de 1988 e estruturadas ao longo dos anos 1990.

Um país subdesenvolvido, pobre, que manteve por mais tempo um regime de escravidão no mundo, com extensões continentais e diversos problemas regionais, com quadro de desigualdades sociais acumuladas ao longo do século XX, tinha sede por políticas públicas que atendessem às demandas da sociedade e que restabelecesse padrões de civilidade a todo o povo. Não eram poucos os desafios colocados na defesa da saúde como direito universal (GERSCHMAN, 2004). Também não eram poucas as forças capazes de levar tais ideias audaciosas adiante. O patamar do qual o país partia no panorama da saúde era bastante limitado e, portanto, desafiante. Entre o período imperial e a chegada da República, no final do século XIX, basicamente a saúde estava estruturada na atenção médica somente nas maiores cidades, por meio do controle das grandes epidemias e da assistência particular às elites. Os pobres, escravos e ex-escravos ficavam dependentes de curas tradicionais e de curandeirismo (ESCOREL; TEIXEIRA, 2008). Em 1808, a vinda da Coroa Portuguesa para o 
Brasil, após a invasão espanhola, trouxe também três conjuntos de importantes instituições de saúde: 1. várias instituições de vigilância sanitária, 2. a Fisicatura-mor de Saúde, responsável por fiscalizar o exercício da medicina e 3. a Provedoria-mor de Saúde, para garantir a salubridade da Corte, fiscalizando navios que atracavam no litoral brasileiro.

Já em 1828, as Fisicaturas foram extintas e as atividades de saúde foram transferidas para as câmaras municipais. A essas câmaras de saúde cabia a responsabilidade pela vacinação em períodos de grande epidemia (varíola, febre amarela, entre outras), pelo controle de entrada de escravos doentes nas cidades, pela expulsão das áreas urbanas de doentes contagiosos e pela purificação dos ambientes com cremação de ervas (ESCOREL; TEIXEIRA, 2008). Em 1832, a criação das primeiras faculdades de medicina tornou possível, enfim, a formação de médicos brasileiros, embora tais médicos ficassem restritos à medicina privada ou, quando muito, atendessem pequena parte da população pelas Santas Casas de Misericórdia, que ofereciam internações graves nas enfermarias improvisadas durante as grandes epidemias.

No início do século $\mathrm{XX}$, as mudanças relacionadas a um maior crescimento das cidades, à industrialização e à dinamização dos setores da economia trouxeram novos desafios para a saúde. Uma das principais medidas do início do século foi o estabelecimento da vacinação obrigatória em todo o território nacional, o que causou inclusive uma série de revoltas populares que ainda não tinham assimilado a importância das novas medidas. Por sua vez, a segregação dos acometidos de infecções, por meio de tratamentos precários, foi a tônica de muitas medidas de saúde nesse período. Ainda no que diz respeito à vacinação, 1900 foi o ano da criação do Instituto Soroterápico Federal (futura Fundação Osvaldo Cruz - Fiocruz), importante instituto público de pesquisa e de fomento a novas técnicas para promoção da saúde coletiva (ESCOREL; TEIXEIRA, 2008). Ao lado das revoltas que ocorriam por causa das vacinações obrigatórias, em 1919, foi criado o Departamento Nacional de Saúde Pública, responsável pelo saneamento rural, que oferecia mais serviços de saúde na perspectiva das atribuições estatais, dando importantes passos para fortalecer a ideia da saúde pública.

Durante a Era Vargas, havia expectativa de centralização do poder estatal a fim de dar dinamicidade e organicidade ao poder público disperso nos limites territoriais. Para o atendimento das reivindicações operárias, Vargas transformou as Caixas de Aposentadorias e Pensões (CAPs), criadas em 1923, nos Institutos de Aposentadorias e Pensões (IAPs), estas organizadas por categorias profissionais e financiamento tripartite (trabalhadores, empregados e Estado). Dentro dos IAPs, a cobertura de atenção em saúde aos trabalhadores e aos seus 
dependentes aumentou (ESCOREL; TEIXEIRA, 2008). Além disso, dando seguimento às perspectivas de centralização do poder estatal e de modernização da administração pública, foi criado, em 1930, o Ministério da Saúde e Educação. Na Constituição de 1946, houve sinalização para articular a saúde preventiva do trabalhador e da gestante à legislação trabalhista previdenciária. Sem novidades até 1956, o sistema de saúde era oferecido por meio de quase 10 IAPs em todo o país. Esse número aumentou para mais de 30 em 1978 (ESCOREL; TEIXEIRA, 2008). Para ter uma ideia dos enormes desafios da cobertura da saúde, segundo Sarah Escorel e Luiz Antônio Teixeira (2008), em 1963, dos 3.677 municípios brasileiros, 2.100 não tinham nenhum equipamento de saúde.

O período da ditadura militar, entre 1964 e 1985, foi marcado por aumento de investimentos na infraestrutura e industrialização do país e, consequentemente, por diminuição de investimentos nas políticas sociais, como a de saúde (GERSCHMAN, 2004). A saúde permanecia preponderante apenas na cobertura aos trabalhadores e seus dependentes. Os demais cidadãos, não segurados, tinham atenção nos raros postos de saúde, desde que fosse atenção maternoinfantil, contra tuberculose e hanseníase, além de pronto atendimento nos escassos hospitais públicos dos grandes centros (ESCOREL; TEIXEIRA, 2008). Desse modo, no final da ditadura militar, surgiu o Movimento da Reforma Sanitária, enquanto o governo Geisel promovia a reabertura democrática de forma lenta, gradual e segura (ESCOREL; TEIXEIRA, 2008). Último presidente militar, Geisel foi responsável pela criação dos Planos Nacionais de Desenvolvimento (PND), com políticas sociais tanto de saúde, de forma mais importante, quanto de assistência social, como demonstrado no capítulo anterior. Em 1985, houve a nomeação de integrantes do Movimento da Reforma Sanitária para cargos do recém-estruturado Ministério da Saúde.

O Movimento da Reforma Sanitária, ou Movimento Sanitário, envolveu profissionais da saúde que compartilhavam o referencial médico-social na abordagem dos problemas de saúde e que buscaram a transformação dos setores de saúde no Brasil em prol da melhoria das condições de saúde e de atenção à saúde da população brasileira, na consecução do direito de cidadania (GERSCHMAN, 2004). Formado por profissionais da saúde, acadêmicos e estudantes, o movimento estabeleceu as bases para a criação do sistema de saúde público e universal durante o período da Constituinte. Em 1986, realizou-se a $8^{\text {a }}$ Conferência Nacional de Saúde, com a presença de mais de 5 mil pessoas, que teve como resolução a definição dos princípios e das diretrizes do Sistema Único de Saúde (SUS). Em 1987, um decreto presidencial criou o Sistema Unificado e Descentralizado de Saúde (SUDS). O passo seguinte 
foi estabelecer, no texto da Constituição Federal de 1988, no artigo 194, a saúde como um direito integrante da seguridade social, ao lado da previdência e da assistência social. Por fim, em 1990, foi promulgada a Lei 8.080, a Lei Orgânica da Saúde (LOS), que regulamentaria o SUS nos anos subsequentes (BRASIL, 1990).

A recuperação desse itinerário que tornou possível que o acesso à saúde alcançasse o patamar de direito de todos e dever do Estado é importante por pelo menos dois motivos. O primeiro deles é estabelecer uma relação histórica, política e econômica a partir da qual emergiu um tema dessa importância ao ponto de assinalar a saúde como um direito de todos os cidadãos, independente de renda, classe e contribuição ao sistema de seguridade social. O segundo motivo é descortinar uma realidade de transição de um sistema limitado e desorganizado para um sistema integrado de saúde, que abre possibilidades para novas bases da atenção em saúde mental serem criadas a fim de superar a hegemonia do modelo manicomial ainda presente nos anos 1990.

O esgotamento do modelo manicomial, na transição da década de 1970 para a década de 1980, ficou reconhecido ao redor do mundo. Questionamentos contundentes sobre o modelo manicomial começaram a se erguer e a ganhar corpo na Europa e nos Estados Unidos da América. O movimento denominado de reforma psiquiátrica ou luta antimanicomial buscava a reorientação do modelo assistencial em saúde mental, escapando da hegemonia hospitalar-manicomial para novas formas de assistência em meio aberto. A luta antimanicomial tinha como um de seus principais pressupostos a mudança na maneira de cuidar: de um predomínio da cultura da internação para um acolhimento da crise. Além disso, a reforma psiquiátrica buscava uma nova maneira de olhar para o território: se antes se buscava o isolamento dos asilos, agora, a rede de atenção precisava ser efetivada nas relações sociais, afetivas, de trabalho e da família dos sujeitos, ou seja, o mais próximo possível de suas realidades. A luta antimanicomial chegou ao Brasil no final dos anos 1970, em momento propício, dado o caldeirão de reivindicações do Movimento da Reforma Sanitária e os demais movimentos populares que lutavam pelo fim do regime militar.

A luta antimanicomial no Brasil pode ser dividida em três grandes momentos. O primeiro deles compreendeu a crítica ao modelo hospitalocêntrico, que começou em 1978 no país e foi até 1991, logo após a aprovação da LOS, que deu as bases ao sistema único de saúde e, portanto, à própria rede de atenção à saúde mental brasileira. O segundo momento promoveu a implantação da rede de atenção psicossocial de forma dispersa no território nacional e desconectada do todo. Esse período, de 1992 a 2000, foi responsável pela criação, 
na cidade de Santos, no estado de São Paulo, das primeiras iniciativas de um equipamento público de base comunitária, responsável por oferecer atendimento ambulatorial aos pacientes com transtornos mentais por meio de uma equipe multiprofissional que visava à atenção integral aos sujeitos. Esse tipo de equipamento público é o que veio a dar origem aos Centros de Atenção Psicossocial (CAPS), criados nacionalmente pelo Ministério da Saúde somente em 2002. Ribeirão Preto, no estado de São Paulo, Rio de Janeiro e Porto Alegre, no Rio Grande do Sul, estabeleceram um equipamento público que ofereceu moradia para os pacientes recém-saídos de manicômios; a Portaria 106, de 2000, instituiu os Serviços Residenciais Terapêuticos (BRASIL, 2004). Além disso, esse segundo momento foi responsável pela aprovação de leis estaduais de reforma psiquiátrica. Por exemplo, em 1992, a Lei 9.716 e a Lei da Reforma Psiquiátrica do estado do Rio Grande do Sul (RIO GRANDE DO SUL, 1992). O terceiro momento foi a própria aprovação da Lei Federal 10.216, em 2001, que consolidou o modelo não asilar de atenção psicossocial em meio aberto para a assistência em saúde mental de base comunitária.

Para que se tenha ideia dos limites encontrados pelo modelo manicomial no Brasil, vale ressaltar a história do Hospital Colônia de Barbacena, criado em 1903. Esse foi um dos manicômios visitados por Basaglia em sua passagem pelo Brasil, e ele mesmo denunciou os horrores vistos lá, dando impulso à luta antimanicomial no país no final dos anos 1970 (ARBEX, 2013). Desde a escolha da cidade mineira para a criação do hospital psiquiátrico, a instalação do hospício em Barbacena foi um misto de estratégia e acaso. Barbacena foi escolhida para receber o hospital colônia como prêmio de consolação por ter sido cotada para ser a capital mineira, mas perdido a disputa para Belo Horizonte. Desde a criação do Hospício de Barbacena, sua finalidade foi deturpada, o que resultou muito mais em um depósito de indesejáveis do que em um hospital para oferecer assistência médica (ARBEX, 2013).

Segundo Daniela Arbex (2013), até a década de 1950, a presença de psiquiatras e clínicos era rara no hospital. Entre 1903 e 1980, morreram mais de 60 mil pessoas no Hospital Colônia de Barbacena (ARBEX, 2013). Parâmetros da Organização Mundial da Saúde (OMS) estabeleciam como referência três internações para cada mil habitantes do país. Em Minas Gerais, com concentração em Barbacena, o número de internações para cada grupo de mil habitantes era sete: a cada duas consultas e meia na rede de saúde, uma pessoa era hospitalizada em Minas Gerais (ARBEX, 2013). Esse horror do caso mineiro fez Basaglia denominar o que vira em Barbacena como nada muito distinto de um campo de concentração nazista, uma metáfora forte para um mundo que ainda se recuperava do pavor do Holocausto. 
Quando o autor desta tese esteve no Hospital Colônia de Barbacena, em 2011, para a coleta de dados do estudo censitário, eu e minha equipe visitamos o Museu da Loucura, que abriga o histórico do horror de Barbacena. Escrevi o seguinte relato de campo, que transcrevo na íntegra:

Se eu disser que, hoje, sou aquela mesma pessoa que foi dormir ontem no frio de $10^{\circ}$ graus da cidade mineira de Barbacena, estarei mentindo... E nem foi porque senti frio também durante todo o dia de muita neblina. Nem é também porque a minha visita, no final do dia, ao Museu da Loucura aqui da cidade me ensinou algo. No fundo, a visita ao Museu da Loucura me desensinou quase tudo que eu tinha aprendido até aqui na minha vida inteira — metafísica, filosófica e sociologicamente falando.

Na virada do século XIX para o XX, inspirados pelos ares republicanos, um local para cuidar dos alienados em Minas Gerais foi erguido no mesmo local onde antes funcionava um asilo para tuberculosos; Foucault daria gargalhadas dessa "coincidência" histórica! Mais de 60 mil pessoas morreram durante os quase 80 anos de funcionamento do Hospital Colônia de Barbacena, talvez, o mais importante manicômio do país durante décadas. Outra coincidência de que Foucault riria assustado é que trens que cortavam os campos mineiros e do Sudeste traziam e abandonavam pessoas de todos os tipos, de todas as discrepâncias, de todos os vestígios de loucuras, de todas as anormalidades mentais (mas não só delas). Como se não bastasse, a faculdade de medicina da cidade e as de outras vizinhas encomendavam cadáveres ao manicômio... Foi preciso o Basaglia, o famoso psiquiatra italiano, em uma visita ao país no final dos anos 1970, ao lado do sociólogo francês Robert Castel, comparar o manicômio de Barbacena aos campos de concentração nazista para que a opinião pública mineira se desse conta do tamanho da desumanidade daquele lugar, que nem mesmo as belas colinas onde se localiza o hospital colônia eram capazes de suavizar.

Hoje, todo esse horror está no museu. Foi reduzido a frases, objetos, números $\mathrm{e}$ fotos que assustam alguns, chocam outros. Mas que, principalmente, se distancia de todos porque na placa a gente consegue nomear o lugar com certa distância: "museu" pacifica nossa culpa, nosso passado, nossos erros, nossos medos, nossa violência súbita de não se deixar reconhecer ali... Mas os anormais continuam lá, seja rindo entorpecidamente quando nosso grupo desceu destrambelhado do táxi, seja durante a própria visita às salas do museu, quando um dos malucos do lugar entra na sala (justo na área em homenagem à luta antimanicomial) nos pedindo umas moedas...

Foi a primeira vez que fui a um museu, sem ser de arte contemporânea. Não foi à toa. Acredito que teria outros olhares se eu já tivesse ido a um museu antes. Mas o letreiro museu da loucura não é suficiente para afastar o passado. Isso não é porque alguns loucos desgarrados, abandonados, ainda perambulam por ali, por existir ao lado um hospital psiquiátrico no mesmo prédio do museu. Sobre a resposta absurda que demos ao problema da loucura há mais de cento e cinquenta anos, não há museu que apazigue o horror. $\mathrm{O}$ fato de termos loucos persistentes no lugar, que era para ser só um museu, nos impede de relatar aos outros a história daquele lugar como se ela 
pudesse pertencer a um passado distante e neutro - mas não é só. A loucura continua sendo criminalizada pelo abandono a alguns poucos quilômetros dali, na residência terapêutica da cidade, descrita pelo nosso taxista como um lugar "não suficiente para tanto abandono dessa gente".

Para quem acha exagero de nosso taxista, a loucura continua criminalizada mais diretamente, então, a alguns bairros dali, no manicômio judiciário, onde trabalhamos por três dias nesta semana. Lá, temos abandonados de outra ordem: a psiquiatria e a justiça ajudam a família a afastar os perigosos do lar, ajudam a afastar da comunidade os usuários de drogas, os idosos insanos, os esquizofrênicos pobres, as mulheres histéricas que discutem com as mães retrógradas, os gays, que lá ainda são doentes com CIDs, os deficientes mentais negros, os psicóticos analfabetos, todos aqueles que nunca se entenderam com este mundo fraco incapaz de receber uma mente que se recusa a se dobrar diante da normalidade da vida previsível e repetitiva. Eu ainda quero ver o dia em que os manicômios judiciários serão nomeados de museu da psiquiatria. Se a loucura é uma liberdade que tem pressa, a normalização pela psiquiatria abençoada pela sociedade e pelas famílias é a corrente pesada e sem chaves sempre exagerada, sempre equivocada, sempre caduca no mundo de todos nós, humanos frágeis.

Barbacena - MG, 10 de junho de 2011.

A luta antimanicomial não é apenas a defesa da desinstitucionalização, a substituição do modelo manicomial pelos serviços de assistência em saúde mental abertos de base não asilar. Tão importante quanto a denúncia do esgotamento de um modelo, a reforma psiquiátrica buscava instalar as bases para a compreensão de que, antes de qualquer coisa, o louco era um sujeito de direitos. Isso significa que o tratamento oferecido a indivíduos com doenças e transtornos mentais não poderia prescindir de seus direitos inalienáveis como cidadãos. As inovações introduzidas pela Lei 10.216, em 2001, têm mais a ver com os direitos a serem afiançados aos indivíduos em sofrimento mental do que com a defesa de uma certeza inquestionável sobre qual modelo de atenção em saúde era preciso instalar no país.

A Lei 10.216 estabeleceu nove direitos básicos que devem ser afiançados à pessoa em sofrimento mental pelo Estado durante a atenção em saúde: 1. ter acesso ao melhor tratamento do sistema de saúde, consentâneo às suas necessidades; 2. ser tratada com humanidade e respeito e no interesse exclusivo de beneficiar sua saúde, visando alcançar sua recuperação pela inserção na família, no trabalho e na comunidade; 3. ser protegida contra qualquer forma de abuso e exploração; 4. ter garantia de sigilo nas informações prestadas; 5 . ter direito à presença médica, em qualquer tempo, para esclarecer a necessidade ou não de sua hospitalização involuntária; 6. ter livre acesso aos meios de comunicação disponíveis; 7. receber o maior número de informações a respeito de sua doença e de seu tratamento; 8 . ser 
tratada em ambiente terapêutico pelos meios menos invasivos possíveis; e 9. ser tratada, preferencialmente, em serviços comunitários de saúde mental (BRASIL, 2001).

Além disso, uma importante inovação da Lei 10.216 são as regulamentações a respeito dos tipos e das modalidades de internação psiquiátrica. A Lei da Reforma Psiquiátrica não eliminou a possibilidade da internação psiquiátrica. Porém, regulou como devem ser as internações. Ficaram estabelecidos na lei três tipos de internação: a voluntária, a involuntária e a compulsória. A internação voluntária é aquela que ocorre a pedido do paciente e, portanto, a saída também deve ocorrer a pedido dele. Já a internação involuntária é aquela feita sem a vontade do paciente, a pedido da família ou por indicação de profissionais. Nesse caso, para superar as mazelas ocorridas durante o modelo manicomial, a instituição que recebe o paciente deve comunicar a internação ao Ministério Público no prazo de 72 horas (BRASIL, 2001). Consequentemente, a saída a pedido da família e/ou do profissional também deve ser comunicada ao Ministério Público. Por fim, a internação compulsória é a internação autorizada pelo juiz e, como decorrência, a saída também deve ser autorizada por ele (BRASIL, 2001).

No segundo parágrafo do artigo $1^{\circ}$ da Lei 10.216, sobre os direitos e a proteção das pessoas acometidas de transtorno mental, ficou garantido que "o tratamento em regime de internação será estruturado de forma a oferecer assistência integral à pessoa portadora de transtornos mentais, incluindo serviços médicos, de assistência social, psicológicos, ocupacionais, de lazer, e outros" (BRASIL, 2001). Nesse sentido, estabeleceu-se de forma imbricada a relação entre serviços substitutivos de saúde mental e direitos sociais a serem garantidos aos indivíduos em sofrimento mental. De um lado, a Lei da Reforma Psiquiátrica firmou o compromisso do poder público em afiançar os direitos básicos de cidadania a esse público. De outro, assumiu as limitações da política de saúde em oferecer assistência psiquiátrica ao destinar que a promoção da cidadania necessitaria da intersetorialidade entre as áreas de assistência social, esporte e lazer, educação, cultura e emprego na perspectiva da atenção integral às demandas dos sujeitos.

Com a Lei 10.216, várias estratégias e diretrizes precisaram estar presentes para a reorganização da rede de atenção em saúde mental. A primeira delas precisou ser a expansão e qualificação dos CAPS, que foram criados ao longo dos anos 1990 e oferecem atendimento ambulatorial ao indivíduo e a sua família, com atendimentos individuais e coletivos, no interior do equipamento público e também no lar e na comunidade dos indivíduos (BRASIL, 2002). Dando sequência, foi preciso tanto implantar Centros de Convivência para os pacientes 
e suas famílias como criar programas de geração de renda e trabalho na perspectiva da ampliação e consolidação da autonomia dos indivíduos. Além disso, foram abordadas questões relacionadas a moradia (aluguel social e outras políticas de habitação), com a criação do Programa De Volta para Casa e dos Serviços Residenciais Terapêuticos, a serem analisados na próxima seção. Por fim, elaboraram-se diretrizes quanto a intervenções na cultura, para mobilização de usuários e familiares, isto é, de todos os atores das redes sociais, no acompanhamento para o tratamento da forma mais integral possível. Para a implementação de todas essas diretrizes, uma importante estratégia foi a política de redução gradual de leitos em hospitais psiquiátricos. Isto é, à medida que os hospitais psiquiátricos eram fechados, havia o repasse de orçamento federal para a implementação dos serviços substitutivos, de acordo com a Lei 10.216 .

Um dos maiores trunfos da Lei da Reforma Psiquiátrica talvez esteja localizado na perspectiva da atenção básica como campo potencial para a estruturação da saúde mental. A lógica tão presente no Sistema Único de Saúde fora incorporada na rede de saúde mental de forma central. A perspectiva da atenção básica como ponto crucial para a atenção em saúde mental permite que a assistência aos pacientes em sofrimento mental ocorra como acolhimento em seu território, o que traz consequências imediatas para a particularidade do sujeito. Isto é, o usuário é atendido onde está: atendimento individual da necessidade e não só da demanda. Não é preciso o deslocamento ou o isolamento do sujeito para receber assistência. A lógica do território nas políticas sociais é a garantia dos direitos por meio da ação do Estado in locu. Entende-se a territorialização como a natureza orgânica das relações a partir do Estado em ação em um determinado espaço, considerando suas particularidades, especificidades e características (HEIDTMANN NETO, 2008). Além disso, a atenção básica na saúde mental permite que a intervenção ocorra no contexto familiar: família tanto como parceira no tratamento quanto como alvo de atenção integral também em saúde, e não apenas atenção ao indivíduo em sofrimento mental.

\subsection{Lei 10.216 e o familismo do tipo transferência: a relação perfeita na política social incompleta}

A Lei 10.216 estabeleceu as bases jurídicas para a superação do modelo manicomial. É inegável a força do espírito da lei para abalar as estruturas do modelo asilar centrado no hospital psiquiátrico e estabelecer saídas para a formulação de serviços em outro paradigma. O modo como essa superação vem ocorrendo é objeto de análise em intensos e dedicados 
trabalhos nos últimos anos (BRITTO, 2004; PENALVA, 2007; SOARES, 2006; ZGIET, 2010). Paralelamente ao processo de recepção da Lei 10.216 no ordenamento jurídico brasileiro, os primeiros anos da década 2000 foram emblemáticos pela forma como Estado reorientou as políticas sociais, como as de assistência social, segurança alimentar, saúde e combate às desigualdades sociais, entre outras na perspectiva da universalidade da cobertura dos serviços. Dessa forma, o acúmulo do Movimento da Reforma Psiquiátrica coadunou-se com um momento singular das políticas sociais no país que buscam, de forma atrasada, levar adiante as aspirações ensejadas no texto da Constituição Federal de 1988 e que sofreram contra-ataques ao longo dos anos 1990, como analisado no capítulo anterior.

Como um movimento político e ideológico, o Movimento da Reforma Psiquiátrica não se limita à Lei 10.216. Pelo contrário. Como já mencionado, várias iniciativas regionais, nos estados de São Paulo, Rio de Janeiro e Rio Grande do Sul, que buscavam estabelecer novos parâmetros para a atenção em saúde mental, já tinham aparecido nos anos 1990. Nesse sentido, a Portaria 106, do Ministério da Saúde, estabeleceu, em 2000, os Serviços Residenciais Terapêuticos, com o objetivo de garantir assistência aos portadores de transtornos mentais com grave dependência institucional que não tivessem possibilidade de desfrutar de inteira autonomia social e não possuíssem moradia nem vínculos familiares (BRASIL, 2000).

As residências terapêuticas servem para a moradia de pacientes que não têm laços familiares ou não possuem família. Esse equipamento público, destinado para o máximo de oito usuários, oferece três refeições diárias e conta com um médico e dois profissionais de nível médio de referência. Cada residência é referenciada a um CAPS. Em 2012, havia mais de 620 residências terapêuticas no país, o que atendia a quase 3.800 pacientes (BRASIL, 2012). Na esteira da derrocada do modelo manicomial, tais residências buscaram ser uma alternativa para aqueles pacientes que, advindos dos manicômios, não teriam família para recepcioná-los.

Além dos serviços criados, a lei antimanicomial introduziu novas diretrizes nas políticas de saúde mental. Um dos nove direitos assinalados na Lei 10.216 é o que está estabelecido no inciso II, do artigo $2^{\circ}$ : a pessoa com transtorno mental tem o direito de "ser tratada com humanidade e respeito e no interesse exclusivo de beneficiar sua saúde, visando alcançar sua recuperação pela inserção na família, no trabalho e na comunidade" (BRASIL, 2001). Esse preceito institui os fundamentos para a reorientação da atenção em saúde mental na perspectiva ampla da inclusão dos pacientes e não apenas da recuperação de sua saúde. Era 
o giro necessário no arcabouço jurídico para a ampliação das responsabilidades do Estado e a superação do modelo manicomial. No artigo $3^{\circ}$, definiu-se como responsabilidade do Estado e de suas políticas públicas, por meio da política de saúde mental, "a assistência e a promoção de ações de saúde [...], com a devida participação da sociedade e da família, a qual será prestada em estabelecimento de saúde mental [...]" (BRASIL, 2001). Esses são dois dos três lugares na lei antimanicomial em que é citada a família. Não é por menos. A família é um importante agente para constituir a atenção em saúde mental. O trabalho dos serviços de atenção em saúde mental pressupõe a participação das famílias para o atendimento integral ao sujeito.

O apoio cotidiano do núcleo familiar ao paciente, o acompanhamento e uma espécie de supervisão para um melhor cumprimento dos requisitos do tratamento, além do reforço das relações afetivas entre paciente e família, são importantes para o restabelecimento das condições de saúde daqueles em sofrimento mental. Saindo de uma perspectiva em que simplesmente oferecia os pacientes para o isolamento nos manicômios, a família agora foi integrada às possibilidades de acompanhamento para a recuperação da saúde mental dos indivíduos e para projeções de inclusão social. Ademais, o processo de desinstitucionalização provocado pela reforma psiquiátrica pressupõe que a família é um dos importantes locus de inserção dos indivíduos para o desenvolvimento e a manutenção de suas relações sociais.

A relação entre paciente e família não se dá de forma simples. Os contratempos a respeito dessa afirmação da família como um dos agentes responsáveis pelo acompanhamento dos pacientes em sofrimento mental surgem em duas situações particulares. A primeira delas é quando os contatos e o convívio entre paciente e família são inexistentes, isto é, quando o paciente tem laços fragilizados com a família, ou não tem núcleo familiar, ou então não tem possibilidade de restabelecer tais contatos. Essa é uma situação comum entre as pessoas advindas dos manicômios, principalmente para os indivíduos em sofrimento mental que cometeram crimes, receberam uma medida de segurança de tratamento psiquiátrico obrigatório e já cumpriram os critérios para a desinternação. O segundo contratempo decorre da ausência de ações públicas, de profissionais de saúde, de uma rede de serviços substitutivos e de equipamentos públicos, como os CAPS e as residências terapêuticas, para os indivíduos que passaram longos períodos em regime manicomial. Desse modo, os pacientes desinternados são simplesmente recepcionados pelas famílias, que oferecem além do convívio socioafetivo e apoio cotidiano - a assistência integral de responsabilidade das políticas públicas inexistentes. Há diferenças importantes entre ser um dos agentes 
responsáveis pelo apoio e pela manutenção de laços socioafetivos para o restabelecimento das condições de saúde dos pacientes em sofrimento mental e assumir a assistência integral dos indivíduos.

O processo de desinstitucionalização necessita de políticas robustas para oferecer assistência aos pacientes que ficaram internados nos manicômios por longo período e, no momento da desinternação, estão gravemente dependentes da instituição. A própria Lei 10.216 assinala, no artigo $5^{\circ}$, que o paciente com dependência institucional decorrente de seu quadro clínico ou da ausência de suporte social "será objeto de política específica de alta planejada e reabilitação psicossocial assistida, sob responsabilidade da autoridade sanitária competente e supervisão de instância a ser definida pelo Poder Executivo" (BRASIL, 2001). Entretanto, a execução desse tipo de política é complexa e teve pouco êxito nos últimos anos.

Além das residências terapêuticas, uma política importante para esse público é o Programa De Volta para Casa (BRASIL, 2003). O programa foi instituído pela Lei Federal 10.708, em 31 de julho de 2003, e dispõe sobre a regulamentação do auxílio-reabilitação psicossocial a pacientes que tenham permanecido em longas internações psiquiátricas. $\mathrm{O}$ objetivo do programa é contribuir para a inserção social efetiva dessas pessoas, por meio da criação e do incentivo de uma rede ampla e diversificada de recursos assistenciais e de cuidados, que facilite o convívio social e que seja capaz de assegurar o bem-estar integral e estimular o exercício pleno dos direitos civis, políticos e de cidadania dos pacientes. Segundo dados mais recentes do Ministério da Saúde, em fevereiro de 2012, o Programa De Volta Para Casa alcançou mais de 4 mil beneficiários em folha de pagamento (BRASIL, 2012a). Em 2003, ano de criação do programa, o número de atendimentos era de 206 pacientes. Apesar do número crescente, a cobertura do programa ainda é limitada.

Por meio de uma parceria com a Caixa Econômica Federal, o programa conta hoje com beneficiários em todo o território nacional, que recebem mensalmente em suas contas bancárias o valor de $\mathrm{R}$ \$240,00. O auxílio-reabilitação psicossocial é destinado àqueles que, por falta de alternativas, foram submetidos a tratamentos aviltantes e privados de seus direitos básicos de cidadania. Embora tenha características mais da política de assistência social do que da própria saúde, o Programa De Volta para Casa é avançado em termos da intersetorialidade entre as ações para atenção integral das demandas dos pacientes em sofrimento mental. Em conjunto, o Programa de Redução de Leitos Hospitalares de Longa Permanência, as residências terapêuticas e o Programa De Volta para Casa estabelecem as bases para contribuir no processo de desinstitucionalização, por meio da promoção da 
cidadania das pessoas em sofrimento mental submetidas à privação da liberdade nos hospitais psiquiátricos e nos HCTPs brasileiros.

Por fim, a Lei 10.216 estabeleceu as condições para a criação, de forma padronizada em todo o país, dos serviços dos CAPS, já iniciados de forma localizada ao longo dos anos 1990 em alguns estados brasileiros das regiões Sul e Sudeste. Os CAPS foram instituídos nacionalmente por meio da Portaria 336, de 2002, do Ministério da Saúde. Eles são serviços de atendimento ambulatorial e devem estar capacitados para atender prioritariamente pacientes com transtornos mentais severos e persistentes em sua área territorial, em regime de tratamento intensivo, semi-intensivo e não intensivo (BRASIL, 2002). Os serviços oferecidos pelos CAPS constituem a espinha dorsal do modelo antimanicomial e não asilar de assistência em saúde mental. São cinco modalidades de CAPS: tipos 1 e 2 (que se diferenciam pelo porte das cidades e pelo número máximo de pacientes atendidos por dia), tipo 3 (que funcionam 24 horas e permitem internação até 7 dias ininterruptos), CAPS AD - álcool e drogas (que atendem exclusivamente pacientes com demandas relacionadas a álcool e outras drogas) e CAPSi (especializados em crianças e adolescentes em sofrimento mental e em situação de abuso de álcool e outras drogas). A rede dos CAPS abarca todas as situações de atenção psicossocial em regime ambulatorial ancorado na atenção básica e segue a lógica do território para atendimento às particularidades dos pacientes e de suas famílias. Dados mais atualizados do Ministério da Saúde registram 1.742 CAPS em 2012 no país, o que resulta em mais de 7,8 milhões de atendimentos por ano (BRASIL, 2012a). Como o processo de reforma psiquiátrica no Brasil é compreendido como um conjunto de transformações de práticas, saberes e valores em relação à pessoa com transtorno mental, os CAPS cumprem papel primordial para atendimento dessa lógica.

Para enfrentar a centralidade do hospital psiquiátrico, os CAPS tiveram de ser formulados não exclusivamente para oferecer atendimento para as funções de internação e atendimento ambulatorial, mas principalmente para se aproximar das demandas particulares de cada paciente, na sua relação com a comunidade e a família. Os CAPS estruturados sob a lógica do território permitem também que os processos de produção de saúde mental relacionados às experiências de outros adoecimentos, de violência, de abuso sexual e de dependência de álcool e outras drogas aconteçam em territórios determinados: na família, na comunidade, nos universos existenciais das pessoas. Nesse sentido, pelo fato de os processos de adoecimento mental serem gerados nesses territórios específicos, os serviços substitutivos estão mais preparados para acompanhar a dinamicidade da existência dos pacientes. 
Dada a desarticulação do regime hospitalocêntrico no atendimento manicomial, foi preciso estabelecer alternativas para a completa estruturação dos serviços substitutivos em saúde mental. No entanto, a velocidade com que esses serviços foram sendo criados no Brasil não atendeu ainda de forma integral a todos os pacientes egressos dos manicômios. $\mathrm{O}$ resultado imediato dessa transição incompleta recai sobre as famílias, que devem oferecer apoio aos indivíduos, que não estão mais isolados nos manicômios, como ocorreu por quase duzentos anos. Estima-se que aproximadamente 23 milhões de pessoas necessitam de cuidados em saúde mental no Brasil (BRASIL, 2014b). Com os números mostrados anteriormente dos serviços e programas, é possível perceber o universo de desproteção ainda existente no cenário brasileiro. Nesse sentido, por causa da não implementação dos serviços substitutivos e do fato de que a estratégia de redução de leitos psiquiátricos foi relativamente eficiente para o fechamento dos manicômios tradicionais, a responsabilidade por recepcionar os pacientes em sofrimento mental ficou a cargo, na maioria dos casos, da própria família.

A desinstitucionalização ocorreu, mas a responsabilidade por atenção e assistência aos pacientes foi transferida para os núcleos familiares. Tanto nos momentos posteriores à desinternação quanto nos momentos posteriores à primeira internação em clínicas que cumprem com os pré-requisitos estabelecidos na Lei 10.216, a família assume uma rede de atenção fundamental como aparato para os pacientes, que agora não contam com as instituições totais dos manicômios. O papel que a família deveria adquirir com a reforma psiquiátrica nada tem a ver com assumir de forma prioritária a assistência integral dos sujeitos. Mas, dada a inexistência ou insuficiência dos equipamentos públicos, tais responsabilidades são transferidas às famílias, caracterizando um familismo do tipo transferência. Se esboçarmos conjecturas superficiais e recuperarmos a intensa mudança de composição familiar nos últimos 30 anos no país, vamos perceber que as mulheres, que são quem oferece de forma primordial os cuidados no interior dos lares, já não estão mais presentes integralmente nas famílias, pela sua inclusão maciça no mercado de trabalho (PRIORE, 1997).

A análise sobre o papel da família na provisão de bem-estar tem, pelo menos, duas perspectivas necessárias de aprofundamento: uma político-jurídica e uma econômicodemográfica. Entre as duas, está o debate republicano sobre até que ponto ingerências públicas devem modelar as características e atribuições das famílias em relação a garantias dos direitos individuais de todos, no interior delas e na relação com a sociedade. Para Martha Nussbaum, um ponto de partida importante é salientar que "a configuração da estrutura 
familiar e dos privilégios e direitos dos membros da família é, em muitos aspectos, produto da ação do Estado" (2000, p. 344). As famílias não são instituições à parte do funcionamento do Estado e da sociedade, nem algo que vai de encontro aos objetivos da administração pública. Tampouco são algo exterior ao funcionamento dinâmico das mudanças sociais ou uma espécie de anterioridade na sua conformação em relação às estruturas sociais, entre elas as políticas e as jurídicas. Isto é, a família não é algo que exista antes da conformação das atribuições públicas do Estado como gestor do bem-estar de todos. A família nasce e é definida exatamente pelas estruturas do Estado. Antes de um conceito cultural e histórico, ela só existe como definição jurídica, por meio de leis, regulamentos e autorizações pactuadas no ordenamento legal.

A família é lugar para o desenvolvimento e a proteção das pessoas, para a associação pessoal, para as expressões afetivas. Entretanto, esse lugar não deve ser uma arena de consolidação e reprodução de desigualdade de representação e de atribuições. Há uma falsa dicotomia que coloca a família como um ente privado e isolado da sociedade, na qual o direito à privacidade protege e afasta os interesses coletivos dos interesses do interior dos núcleos familiares. No entanto,

os indivíduos têm direito à privacidade, na forma das liberdades associativas e de decisão. Mas não há instituição alguma que tenha direitos de privacidade que nos impeça de perguntar como a lei e a política pública têm modelado essa instituição e como essas instâncias poderiam modelá-la ainda melhor (NUSSBAUM, 2000, p. 324).

$\mathrm{Na}$ perspectiva dos direitos individuais e dos direitos humanos, as famílias precisam ter um funcionamento que permita o tratamento de cada indivíduo como um fim em si mesmo e não como um meio para outra finalidade de outro membro familiar (NUSSBAUM, 2000). Essa perspectiva permite que a pessoa, considerada de forma separada, seja a unidade básica para a distribuição política (NUSSBAUM, 2000). As leis e as políticas públicas devem ser modeladas para acompanhar essa perspectiva.

No contexto econômico-demográfico da família no Brasil, observou-se, da década de 1970 até os dias de hoje, que a participação das mulheres no mercado de trabalho tem apresentado impressionante progressão. Se em 1970 apenas 18\% das mulheres brasileiras em idade produtiva trabalhavam, esse número chegou, em 2009, a mais da metade das mulheres, 52,4\% (PNAD, 2010). Além disso, em 2009, 35\% das famílias eram chefiadas por mulheres, número que subiu $10 \%$ se considerado o período de sete anos antes, desde 2002 (PNAD, 
2010). A mudança na composição de perfil dos ramos de atividades no mercado de trabalho nos últimos quarenta anos, como o crescimento do setor de serviços, bem como o uso de métodos contraceptivos, as famílias chefiadas por mulheres, a maior independência feminina e a realização pessoal são algumas das explicações para a maior participação das mulheres no mercado de trabalho a partir dos anos 1970 .

A consequência imediata para as pessoas com transtornos mentais é que, se antes as mulheres eram compreendidas como aquelas que ofereceriam o cuidado integral no ambiente do lar, cada vez menos, elas têm tal disponibilidade. Tal situação não se restringe às pessoas em sofrimento mental, mas é extensivo principalmente às crianças, aos idosos e às pessoas com deficiência. Assim, além de todas as mudanças políticas e jurídicas desde os anos 1990 e 2000 na política de assistência social e de saúde mental, com a reforma psiquiátrica, o cuidado dos indivíduos em sofrimento mental ainda enfrentou esse hiato criado pela entrada das mulheres no mercado de trabalho.

\subsection{Experiências das medidas de segurança em liberdade: o caso de Minas Gerais, Goiás e os limites com o familismo}

Da assistência social às políticas de saúde mental, a passagem mais desafiante para os princípios da reforma psiquiátrica se localiza na aplicação das medidas de segurança. No capítulo anterior, percorreu-se a trajetória da política de assistência social ancorada em princípios contemporâneos que, embora organizem suas práticas, também se emaranham com determinantes do passado que remodelaram os princípios do familismo na intervenção estatal ao garantir as necessidades básicas. Esse movimento não foi diferente com as políticas de saúde mental, como analisado nas seções anteriores: rompido o legado do modelo manicomial, o familismo manteve-se presente nas ações que necessitam da atuação das famílias como suporte ao funcionamento dos serviços substitutivos de saúde mental. Diante desse cenário, a aplicação das medidas de segurança em meio aberto, orientadas pelos princípios da luta antimanicomial coadunados na Lei 10.216, depara-se com desafios em todo o país, representando, certamente, a última fronteira da reforma psiquiátrica.

Nesse sentido, desde a promulgação da Lei 10.216, há uma expectativa de que os princípios da reforma psiquiátrica alcancem a aplicação das medidas de segurança (PENALVA, 2007). Em 2010, o Ministério da Justiça publicou uma pesquisa mostrando as influências da Lei 10.216 na aplicação dessas medidas. Um dado relevante sobre a não incorporação das diretrizes da Lei 10.216 na execução das medidas de segurança é que, dos 228 dossiês analisados de pessoas em medida de segurança nos estados da Bahia e de Minas 
Gerais, apenas em 11 havia referência explícita à lei como diretriz capaz de orientar a aplicação da medida de internação (MINISTÉRIO DA JUSTIÇA, 2010). Em apenas dois dos 11 casos encontrados era o juiz que mencionava a Lei da Reforma Psiquiátrica; nos outros 9, a Lei 10.216 aparece por menções da defensoria pública em argumentações geralmente para defender a inclusão do paciente em medida de segurança nos serviços substitutivos de assistência em saúde à população em sofrimento mental (MINISTÉRIO DA JUSTIÇA, 2010).

Mas a Lei 10.216 tem influenciado a aplicação das medidas de segurança de outros modos. Em 2004, o Conselho Nacional de Política Criminal e Penitenciária (CNPCP) estabeleceu, por meio da Resolução 5, que as medidas de segurança passariam a ser executadas em HCTPs, tendo a lei antimanicomial como diretriz orientadora (BRASIL, 2004a). Segundo a resolução, “a atenção prestada aos pacientes inimputáveis deverá seguir um programa individualizado de tratamento, concebido por equipe multidisciplinar que contemple ações referentes às áreas de trabalho, moradia e educação e seja voltado para a reintegração sócio-familiar” (BRASIL, 2004a, p. 2). Além disso, naqueles estados onde não houvesse HCTPs, os pacientes deveriam ser tratados na rede de serviços do SUS, como os serviços substitutivos.

Também por influência da Lei 10.216, em 2004 começaram experiências capazes de afetar o cumprimento das medidas de segurança. O estado de Minas Gerais foi o primeiro a levar em consideração os princípios e as diretrizes da Lei da Reforma Psiquiátrica para que os indivíduos submetidos a tratamento psiquiátrico obrigatório pudessem realizar o tratamento em liberdade por meio dos serviços substitutivos não asilares. Desse modo, foi criado, em 2004, o Programa de Atenção Integral ao Paciente Judiciário (PAI-PJ), ligado à Secretaria de Justiça do estado (MINAS GERAIS, 2004). O PAI-PJ fornece acompanhamento psicossocial desde o momento em que é identificado que a pessoa cometeu o crime em situação de sofrimento mental até quando a sentença para cumprimento de medida de segurança é proferida, criando condições para que a pessoa cumpra tal medida em liberdade, em serviços substitutivos de assistência em saúde mental.

Em dez anos de funcionamento do programa PAI-PJ (2004-2014), mais de 790 pacientes foram acompanhados em todo o estado de Minas Gerais, o que teve resultados importantes para o baixo índice de reincidência dos pacientes em medida de segurança (MINAS GERAIS, 2014). A experiência do PAI-PJ inspirou a criação de um programa semelhante em Goiás. O Programa de Atenção Integral ao Louco Infrator (Paili) surgiu em outubro de 2006 mediante um convênio firmado entre a Secretaria de Estado da Saúde, a 
Secretaria de Estado da Justiça, a Secretaria Municipal da Saúde de Goiânia, o Tribunal de Justiça de Goiás e o Ministério Público do Estado de Goiás. A proposta para a criação do programa foi a de modificar as ações de execução das medidas de segurança no estado. Estas deveriam deixar de focar unicamente o prisma da segurança pública para também serem acompanhadas como uma questão de saúde pública. O Paili, desde sua criação, fundamenta-se nas disposições da Lei $10.216 .^{5}$

O Programa Paili difere do PAI-PJ em dois aspectos principais. O primeiro deles é que Goiás é uma das unidades federativas que não possuem Hospital de Custódia e Tratamento Psiquiátrico ou Ala de Tratamento Psiquiátrico. Já Minas Gerais, onde fica o programa PAIPJ, possui três Hospitais de Custódia e Tratamento Psiquiátrico, nas cidades de Barbacena, Juiz de Fora e Ribeirão das Neves. As pessoas em medida de segurança em Goiás ou estão atendidas pelo Paili, ou cumprem medida de segurança em presídios e penitenciárias comuns. Não há informações sobre quantos indivíduos em medida de segurança estão em presídios ou penitenciárias comuns, o que dificulta análises a respeito da cobertura do Paili. A segunda diferença entre o PAI-PJ e o Paili é que o programa mineiro está ligado à Secretaria de Justiça e o programa goiano é ligado à Secretaria de Saúde, o que possibilita uma melhor integração no momento de oferecer assistência em saúde mental aos indivíduos em medida de segurança. Em todo o estado de Goiás existem 120 comarcas. Não tivemos informação de número exato de comarcas conveniadas ao Paili, mas sabe-se que cerca de 40 são alcançadas pelo programa. Este faz convênio com municípios onde há pacientes em medida de segurança, mas não há serviços de saúde mental como hospitais psiquiátricos ou serviços substitutivos. Normalmente o juiz da comarca, depois da sentença, encaminha o processo do paciente ao programa. As comarcas só são conveniadas após um caso de sentença de medida de segurança. No total, 198 pacientes já foram acompanhados pelo programa; desses, 16 faleceram e 18 tiveram sua medida extinta (MINISTÉRIO DA JUSTIÇA, 2010). Na análise dos dossiês do Paili, a equipe de pesquisadores teve acesso a 188 dossiês, dos quais 163 estavam ativos e 25 já haviam sido extintos, por morte ou cessação da periculosidade.

Em 2010, o Paili atendeu aproximadamente 160 pacientes em todo o estado. Dados publicados no estudo demonstram o itinerário e o perfil da população atendida pelo Paili (MINISTÉRIO DA JUSTIÇA, 2010). Um dado que mais interessa às análises desta tese é o

\footnotetext{
${ }^{5}$ Em 2010, o autor desta tese participou de um estudo que avaliou o funcionamento do Paili. A pesquisa foi financiada pelo Programa Pensando o Direito, do Ministério da Justiça. Os resultados foram publicados no relatório Loucura e direito penal: uma análise crítica das medidas de segurança (MINISTÉRIO DA JUSTIÇA, 2010).
} 
que diz respeito ao local de moradia dos indivíduos acompanhados pelo programa: $44 \%$ dos pacientes acompanhados pelo Paili residiam com suas famílias, 10\% estavam em presídios, porque a transferência para as famílias ou outras instituições não prisionais ainda não tinha se efetivado, e apenas 3\% estavam em residências terapêuticas, criadas pela portaria do Ministério da Saúde de 2000 (BRASIL, 2000). No caso do PAI-PJ, em março de 2010, 70\% dos pacientes acompanhados residiam com a família. Esses dados apontam para duas questões centrais: a participação significativa das famílias como receptoras dos indivíduos em medida de segurança e a baixa cobertura dos Serviços Residenciais Terapêuticos, que pode ter impacto significativo nos casos em que as pessoas em medida de segurança acompanhadas pelo PAILI e pelo PAI-PJ não têm laços familiares estabelecidos. Desse modo, os dois serviços apontam caminhos importantes a serem amadurecidos para o cumprimento das medidas de segurança nos serviços substitutivos da Lei da Reforma Psiquiátrica, embora os desafios do familismo também estejam presentes nesses casos.

\subsection{Familismo na saúde mental: o circuito familista e os desafios da desinternação}

Um dos princípios orientadores da atuação das equipes multiprofissionais dos serviços substitutivos incentivados pela Lei 10.216 é o princípio da matricialidade. O apoio matricial é um arranjo na organização dos serviços que complementa as equipes de referência. Essas equipes são responsáveis pelos pacientes e geralmente não os encaminham, mas trabalham com o apoio compartilhado da equipe. Tanto os serviços de referência/especialidades (e/ou os especialistas isolados) quanto os outros profissionais que lidam com os pacientes nos serviços de saúde oferecem esse tipo de referência matricial (BRASIL, 2004b). Isto é, no procedimento matricial, a responsabilidade do trabalho desenvolvido pela equipe é compartilhada, o que leva à construção de uma agenda integrada: atendimento conjunto, discussão de casos e supervisão, criação de estratégias comuns para abordar as questões de violência e de abuso de álcool e outras drogas, entre outras relacionadas à temática de saúde mental, e elaboração de um projeto terapêutico singularizado. Essa diretriz é fundamental para o atendimento dos pacientes que cumprem medida de segurança quando estão em fase de desinternação.

Duas exigências são prementes para a consecução dos objetivos da matricialidade em saúde mental: a interdisciplinaridade e a intersetorialidade. A interdisciplinaridade se impõe não como uma proposta de destruição da especialização, já que esta configura o particular que 
se realiza no universal e vice-versa, mas como um convite ou um alerta ao especialista para que este se torne também sujeito da totalidade (PEREIRA, 2014). Para Potyara Pereira (2014), a interdisciplinaridade sugere, pois, uma relação de reciprocidade entre saberes distintos, com suas contradições específicas e inerentes, tendo em vista a recomposição da unidade segmentada do conhecimento. Além disso, na interdisciplinaridade, os saberes se interpenetram a fim de modificar e enriquecer as práticas profissionais (PEREIRA, 2014).

Ao lado da prática da interdisciplinaridade, a intersetorialidade ganha cada vez mais força como uma diretriz para as políticas sociais, e para a saúde mental não é diferente. A intersetorialidade é entendida como instrumento de otimização de saberes; competências e relações sinérgicas, em prol de um objetivo comum; e prática social compartilhada, que requer pesquisa, planejamento e avaliação para a realização de ações conjuntas (PEREIRA, 2014). A intersetorialidade é fundamental para alcançar os objetivos da atenção integral aos pacientes em sofrimento mental. A rede de saúde mental expressa apenas uma das demandas dos pacientes. Para que tal demanda de assistência em saúde seja efetiva, é preciso a relação com as áreas de assistência social, educação, trabalho e emprego, esporte e lazer, e cultura, entre outras (DUARTE; DIAS, 2012). A intersetorialidade permite uma nova lente analítica sobre a rede dos serviços substitutivos em saúde mental, para que tanto as ações tenham essa prática como objetivo quanto os profissionais atuem nessa perspectiva, aliada à prática da matricialidade, orientando-os no fazer técnico-profissional das equipes.

De tal modo os serviços substitutivos têm total imbricação com a rede orientada pelo Programa Saúde da Família que, incentivado pelo Ministério da Saúde desde os anos 1990, ele tem sido o grande balizador da atenção básica em saúde no território nacional. A expansão e a qualificação da atenção básica, organizada pela estratégia Saúde da Família, compõem parte do conjunto de prioridades políticas apresentadas pelo Ministério da Saúde e acompanhadas pelo Conselho Nacional de Saúde. Essa concepção busca ultrapassar a antiga proposição de caráter exclusivamente centrado na doença, desenvolvendo-se, em trabalhos em equipe, por meio de práticas gerenciais e sanitárias, democráticas e participativas, dirigidas às populações de territórios delimitados (BRASIL, 2014b). Dados de janeiro de 2014 apontam que 5.352 municípios brasileiros tinham equipe de saúde da família, o que totalizava mais de 44 mil equipes, com atendimento a uma população estimada em mais de 110 milhões de brasileiros (BRASIL, 2014b). As equipes de Saúde da Família e os agentes comunitários de saúde são peças-chave para a identificação dos casos de indicativos de doenças e transtornos mentais a serem encaminhados para a rede dos CAPS e demais serviços de saúde mental. 
Complementar à atenção em Saúde da Família, foi criado em agosto de 2011 o Serviço de Atenção Domiciliar (SAD). A Portaria 2.029 do Ministério da Saúde define, no artigo 2º SAD como "um serviço substitutivo ou complementar à internação hospitalar ou ao atendimento ambulatorial, responsável pelo gerenciamento e operacionalização das Equipes Multiprofissionais de Atenção Domiciliar (EMAD) e Equipes Multiprofissionais de Apoio (EMAP)" (BRASIL, 2011c). A atenção domiciliar é uma nova modalidade de atenção à saúde substitutiva ou complementar, caracterizada por um conjunto de ações de promoção da saúde, prevenção e tratamento de doenças e reabilitação prestadas em domicílio, com garantia de continuidade de cuidados e de forma integrada às redes de atenção à saúde (BRASIL, 2011c). Além disso, a portaria conceitua o cuidador como a pessoa, com ou sem vínculo familiar, capacitada para auxiliar o paciente em suas necessidades e atividades da vida cotidiana (BRASIL, 2011c).

Em novembro de 2013, o acompanhamento do SAD era garantido por 229 Equipes Multiprofissionais de Atenção Domiciliar e de Apoio espalhadas em 20 estados brasileiros (BRASIL, 2013). Nesse mesmo momento, o programa já alcançava mais de 16 milhões de brasileiros recebendo atendimento domiciliar (BRASIL, 2013). Como uma inovação para reduzir o número de pacientes hospitalizados e com encaminhamentos indevidos aos prontossocorros, a modalidade de Atenção Domiciliar destina-se aos usuários que possuam problemas de saúde e dificuldade ou impossibilidade física de locomoção até uma unidade de saúde; e que necessitem de cuidado com maior frequência, bem como de recursos de saúde e acompanhamento contínuos. Esses usuários podem ser oriundos de diferentes serviços da rede de atenção (BRASIL, 2011c).

É inquestionável a importância de iniciativas como essa. Embora de forma periférica à temática desta tese, pelo fato de a atenção domiciliar não ser destinada ao público em sofrimento mental (apesar de ser um público potencial), o SAD foi aqui analisado para dar conta de uma particularidade no que diz respeito aos cuidadores necessários para que o serviço seja oferecido no domicílio. No artigo 16 da referida portaria, no parágrafo único, fica estabelecido que "para admissão de usuários nesta modalidade é indispensável à presença de um cuidador identificado" (BRASIL, 2011c). O serviço exige que as famílias tenham um cuidador definido — seja membro da família, seja um particular — para a execução das atividades de acompanhamento dos pacientes a serem atendidos no domicílio.

Uma das atribuições do SAD é, inclusive, "I - identificar e treinar os familiares e/ou cuidador dos usuários, envolvendo-os na realização de cuidados, respeitando limites e 
potencialidades de cada um" e "II - abordar o cuidador como sujeito do processo e executor das ações" (BRASIL, 2011c, artigo 30). Dessa forma, esse importante serviço é executado, mas a atribuição do cuidador fica a cargo das famílias, que inclusive são obrigadas a disponibilizar o cuidador para que o serviço no domicílio ocorra. Os cuidados oferecidos no domicílio destinam-se principalmente a casos de pacientes em recuperação de cirurgia, doenças crônicas, fraturas, cuidados relacionados ao envelhecimento e demais traumatismos com possibilidade de atendimento em domicílio. Não há previsão de atendimento do SAD relacionado à saúde mental. O importante a ser destacado nesse serviço é a persistência da transferência de responsabilidades às famílias, mantendo-se um cuidado como exigência. Essa demarcação explicita no texto da Lei que destina às famílias a responsabilidade de dispor do cuidador é também uma das formas que caracteriza o familismo do tipo transferência. A despeito da temática do Serviço de Atendimento Domiciliar não incorporar ainda situações de saúde mental não deixa de ser elucidativo o modo como o familismo também se manifesta neste tipo de serviço de saúde.

De modo bastante semelhante ao debate atual na política de assistência social, nas iniciativas embrionárias a respeito de cuidadores para as pessoas com deficiência que têm sido executadas nos Centros-Dia (CRUZ, 2011), a política de saúde não tem disponibilizado cuidadores para aqueles que precisam de cuidados constantes no domicílio. De um lado, a política de assistência social não permite que os Centros-Dia atendam casos de doenças e transtornos mentais, mas também não proíbe. De outro, os SADs seriam uma importante política da atenção integral à saúde, mas também não fazem referência às pessoas com doenças e transtornos mentais. O próprio texto da portaria estabelece que a responsabilidade do cuidador deve ficar a cargo das famílias. De modo geral, o oferecimento de cuidados constantes a pessoas com deficiência e pessoas idosas nos domicílios tem recebido tímidos avanços tanto da política de assistência social quanto da política de saúde — apesar de ambas serem omissas a respeito das pessoas com doenças e transtornos mentais, o que transfere a responsabilidade, mais uma vez, para as famílias.

O tipo de familismo presente na política de assistência social, caracterizado no capítulo anterior como circuito familista, é extensivo à política de saúde mental. O processo de desinstitucionalização ocorrido no país após a promulgação da Lei 10.216 foi possível, entre outros fatores, pelo fato de que as famílias assumiram parte da responsabilidade de assistência a ser oferecida pelos serviços substitutivos ainda insuficientes. O familismo surge não por uma total ausência das políticas públicas, mas por uma rede intricada em que, por 
vários momentos, a família compartilha com o Estado a responsabilidade de oferecer assistência aos indivíduos em sofrimento mental. O Programa De Volta para Casa, os CAPS e os Serviços Residenciais Terapêuticos são insuficientes para cobrir os aproximadamente 23 milhões de brasileiros que possuem algum tipo de doença ou transtorno mental. O processo de desinstitucionalização que pôs fim à hegemonia manicomial forçou as famílias a recepcionar os indivíduos advindos dos leitos psiquiátricos fechados. Além disso, a ausência de políticas de cuidadores responsáveis por assistir cotidianamente os indivíduos em sofrimento mental pode transferir para as dinâmicas familiares um encargo que certamente traz impactos para o bem-estar das famílias. Esse cenário faz parte da vida dos indivíduos em medida de segurança em fase de desinternação.

No complexo circuito da política de saúde mental, em que a família está presente em várias fases ao prover necessidades e apoio aos indivíduos em sofrimento mental, o modelo do familismo pode causar uma desproteção generalizada quando o indivíduo não tem laços de afeto e convívio com a família. No caso dos indivíduos em medida de segurança, essa desproteção é ainda mais grave, porque a ausência de relações entre o indivíduo e sua família resulta na perpetuação da restrição de liberdade nos manicômios judiciários. O nível de cobertura limitado dos serviços substitutivos leva a responsabilidade de provisão material, social, afetiva e econômica para a família. Entretanto, o próprio funcionamento das políticas, dos programas e dos serviços que apostam nessa relação com a família pode reforçar os laços familistas no interior das ações públicas, o que traz consequências para a garantia dos direitos humanos das pessoas em sofrimento mental.

São muitas as causas que levaram à conformação dessas características nas políticas de assistência social e saúde mental no Brasil. Certamente, o circuito familista apresenta traços particulares em cada território e em cada realidade específica, pelos perfis diferenciados de cobertura da política de assistência e saúde mental no país. Ao caracterizar o familismo presente também na política de saúde mental, esta análise não tem o objetivo de apontar, de forma pessimista, apenas aquilo que não alcançou êxito no processo de substituição do modelo manicomial. Esta investigação visa apontar caminhos capazes de realizar diagnósticos e oferecer quadros de análises específicos para aprofundar a discussão a respeito das estratégias a serem incorporadas no Movimento da Reforma Psiquiátrica — que, ainda vivo, reinventa-se cotidianamente cumprem medida de segurança. Nos dois capítulos a seguir, serão apresentados o perfil dos 
indivíduos esquecidos e o desafio da arquitetura das políticas de saúde mental e de assistência social direcionadas a eles. 


\section{OS ESQUECIDOS DOS MANICÔMIOS JUDICIÁRIOS BRASILEIROS}

Foram precisos 90 anos depois da criação do primeiro manicômio judiciário brasileiro, o Hospital de Custódia e Tratamento Psiquiátrico Heitor Carrilho, fundado em 1921 no estado do Rio de Janeiro, para que a sociedade brasileira conhecesse um retrato da população que vive nos 26 estabelecimentos de custódia e tratamento psiquiátrico no Brasil (DINIZ, 2012). Ao todo, 3.989 homens e mulheres habitavam os 26 manicômios judiciários espalhados em 19 unidades da Federação em 2011 (DINIZ, 2012). Entre a punibilidade inaugurada em 1940, com a publicação do novo Código Penal, e a Lei 10.216, de 2001, os indivíduos inimputáveis por doença e deficiência mental ocuparam um lugar estranho ao ordenamento jurídico, penal e social brasileiro: não são imputáveis, mas são submetidos a um tratamento psiquiátrico obrigatório que os priva de liberdade. Desde 2001, o Estado brasileiro reconhece o regime asilar como inaceitável para a assistência pública aos indivíduos em sofrimento mental (BRASIL, 2001). Essa compreensão tem chegado timidamente até a legislação penal e o cumprimento das medidas de segurança, como demonstrado no capítulo anterior.

Entre as inúmeras situações de violação de direitos da população dos ECTPs, como atrasos na averiguação das condições de saúde mental dos indivíduos que justifiquem a continuidade da internação, os dados referentes aos indivíduos que deveriam estar em liberdade, por já terem cumprido os critérios para a desinternação, chamam atenção pela gravidade da violação de direitos humanos básicos. O estudo censitário mostrou que $25 \%$ das pessoas em medida de segurança estavam indevidamente em restrição de liberdade nos ECTPs (DINIZ, 2012). A realização anual do exame de cessação de periculosidade de $41 \%$ dos indivíduos em todo o país estava atrasada, por isso é muito provável que o número de internações indevidas seja ainda superior aos $25 \%$.

Os dados referentes aos indivíduos que já deveriam estar em liberdade indicam os desafios para as políticas sociais destinadas à população em medida de segurança. Por um lado, apontam a insuficiência dessa temática ser analisada apenas pelo prisma da política de segurança pública. Por outro, revelam que, apesar das políticas de assistência social e saúde mental capazes de oferecer assistência às pessoas em medida de segurança, assentadas na lógica da proteção social e dos direitos humanos, a implementação de tais ações é um dos desafios contemporâneos para o Estado democrático de direito. Desde 1940, as demandas das pessoas em medida de segurança têm sido assimiladas apenas pela política de segurança 
pública. Deslocar tais demandas para a atenção das políticas de assistência social e de saúde mental é um dos objetivos que esta tese busca alcançar ao alargar as tentativas de compreensão das razões que levaram ao esquecimento dos indivíduos dentro dos muros dos manicômios judiciários.

Pobreza, baixa escolaridade, falta de formação profissional, descontinuidade do acompanhamento médico e psicossocial na assistência em saúde e relações familiares fragilizadas são alguns dos elementos que interferem no processo de inserção social, comunitária e familiar dos indivíduos em sofrimento mental (MARTINS, 2014; MECLER, 2010; SILVA, 2010; ZGIET, 2010). Essa conjectura é extensiva à fase de desinternação dos indivíduos em medida de segurança. Partindo desse pressuposto, a Lei 10.216 passou a orientar-se no tripé família, trabalho e comunidade como a articulação necessária para a atenção integral aos indivíduos com doenças e transtornos mentais. Desde o nascimento dos asilos manicomiais, no século XIX, houve o surgimento da tutela aos incapazes de todo gênero, como crianças, idosos e pessoas com deficiência, em relação à qual a psiquiatria foi importante no processo de exclusão da loucura do meio social das cidades europeias nascentes (CASTEL, 1979; FOUCAULT, 2010a). Nos termos de Foucault, "o primeiro critério para determinar a loucura em um indivíduo consiste em mostrar que é um homem inapto ao trabalho" (2010a, p. 261). Nesse sentido, a relação entre políticas sociais, vulnerabilidades e vida produtiva é fundamental para compreender os processos de inclusão social e garantia dos direitos de cidadania necessários na perspectiva da reforma psiquiátrica.

O objetivo deste capítulo é apresentar um perfil detalhado das pessoas em medida de segurança que estão indevidamente em restrição de liberdade nos ECTPs do país. Após os critérios penais e psiquiátricos para a desinternação, os indivíduos continuam enclausurados sem perspectiva de retorno à liberdade. A apresentação do perfil das pessoas em medida de segurança denominadas aqui de esquecidos dos manicômios judiciários será realizada em comparação com os dados dos demais indivíduos em medida de segurança, que ainda não estão em condições de retorno à liberdade. Essa metodologia de apresentação dos dados visa aprofundar as análises a respeito do perfil dos esquecidos. Para o estudo de caso realizado no Distrito Federal sobre o itinerário da desinternação dos indivíduos em medida de segurança dados a serem apresentados no próximo capítulo - , contrastar os dados dos esquecidos com os dos demais em medida de segurança favorecerá a emergência de possibilidades analíticas a serem aprofundadas. Além disso, a apresentação desse panorama dos esquecidos dos manicômios judiciários brasileiros torna público o perfil para futuras análises e reflexões a 
serem conduzidas por outros interessados, como pesquisadores, profissionais da saúde, gestores e formuladores de política pública que lidam com a temática.

\subsection{O perfil sociodemográfico dos indivíduos em medidas de segurança}

Os principais dados sociodemográficos sobre os indivíduos em cumprimento de medida de segurança em ECTP em 2011 foram relativos à idade, cor da pele/raça, conjugalidade, escolaridade e profissão. Nas Tabelas 1, 2, 3, 4 e 5 a seguir, os dados apresentados demonstram várias camadas de vulnerabilidades experimentadas pelos indivíduos em medida de segurança nos ECTPs no Brasil:

Tabela 1 Faixa etária dos esquecidos e dos indivíduos em medida de segurança

\begin{tabular}{lrrrr}
\multicolumn{1}{c}{ Faixa etária } & \multicolumn{1}{c}{ Esquecidos } & & & MS \\
Menos de 20 & 0 & $0 \%$ & 0 & $0 \%$ \\
20 a 24 & 19 & $3 \%$ & 112 & $5 \%$ \\
25 a 29 & 80 & $11 \%$ & 368 & $17 \%$ \\
30 a 34 & 116 & $16 \%$ & 453 & $20 \%$ \\
35 a 39 & 112 & $15 \%$ & 386 & $17 \%$ \\
40 a 44 & 120 & $16 \%$ & 302 & $11 \%$ \\
45 a 49 & 84 & $11 \%$ & 236 & $12 \%$ \\
50 a 59 & 148 & $20 \%$ & 255 & $3 \%$ \\
60 a 69 & 39 & $5 \%$ & 56 & $1 \%$ \\
70 ou mais & 9 & $1 \%$ & 16 & $100 \%$ \\
Sem informação & 14 & $2 \%$ & 31 &
\end{tabular}

Fonte: Pesquisa: A custódia e o tratamento psiquiátrico no Brasil: censo 2011. Ministério da Justiça/Anis: Instituto de Bioética, Direitos Humanos e Gênero.

A maior concentração dos indivíduos em medida de segurança está na faixa entre 20 e 34 anos, com 42\% (933). Entre os esquecidos dos manicômios judiciários, a faixa onde há maior concentração é entre 40 e 59 anos, com 47\% (352) dos indivíduos. Essa concentração indica o processo de envelhecimento que os indivíduos em medida de segurança sofrem dentro dos manicômios judiciários, principalmente entre aqueles que já cumpriram os critérios para o livramento e ainda estão reclusos. A situação dos esquecidos passa a ser desafiante para o funcionamento dos ECTPs, pois gera demandas específicas de assistência cotidiana e até mesmo de especialidades médicas, de alimentação etc., para atender um público em processo de envelhecimento. Além disso, o envelhecimento dos indivíduos em medida de segurança 
impõe desafios extras, na fase de desinternação, à relação com as políticas públicas e com a família para o processo de retorno à liberdade. O próprio Estatuto do Idoso, de 2004, é inteiramente silencioso quanto às demandas da população em reclusão e da população em sofrimento mental de modo geral (BRASIL, 2004).

A Tabela 2 demonstra a distribuição por sexo entre os pacientes dos ECTP:

\section{Tabela 2 Sexo dos esquecidos e da população em medida de segurança}

\begin{tabular}{lrrrrr}
\multicolumn{1}{c}{ Sexo } & Esquecidos & \multicolumn{2}{c}{ MS } \\
Homens & 681 & $92 \%$ & 2046 & $92 \%$ \\
Mulheres & 60 & $8 \%$ & 162 & $7 \%$ \\
Sem Informação & & 0 & $0 \%$ & 7 & $0 \%$ \\
& & & & & \\
& Total & $\mathbf{7 4 1}$ & $\mathbf{1 0 0 \%}$ & $\mathbf{2 2 1 5}$ & $\mathbf{1 0 0 \%}$
\end{tabular}

Fonte: Pesquisa: A custódia e o tratamento psiquiátrico no Brasil: censo 2011. Ministério da Justiça/Anis: Instituto de Bioética, Direitos Humanos e Gênero.

Na população total dos ECTPs, havia, em 2011, 92\% (3.684) de homens e 8\% (291) de mulheres, isto é, uma mulher para cada doze homens (DINIZ, 2012). Como no total da população geral dos ECTPs, constituída em sua maioria por homens, entre os indivíduos esquecidos, havia 8\% (60) de mulheres e 92\% (681) de homens. As mulheres de uma família são quem assume, cultural e historicamente, a função de cuidadoras de crianças, idosos, pessoas com deficiência ou com doenças mentais e demais situações de dependência (GUIMARÃES, 2008; KITTAY, 1998; NUSSBAUM, 2006). Quando são elas quem precisam de apoio para a fase de desinternação, o fato de ser mulher com necessidade de cuidado, pela dependência em razão da internação e do estado de saúde mental, pode levar a dificuldades maiores de retorno à liberdade.

A relação de dependência e cuidados pessoais de terceiros têm sido uma temática crescentemente introduzida na agenda das políticas sociais, principalmente de assistência social e saúde mental e tem a ver, sobremaneira, com os indivíduos em sofrimento mental em fase de desinternação das medidas de segurança. Concebida até pouco tempo atrás como um assunto privado das famílias e geralmente como atribuição inscrita na identidade feminina, a necessidade do cuidado paulatinamente ganhou estatuto de uma questão a ser assumida, ainda que parcialmente, pela esfera pública (SORJ; FONTES, 2012). A necessidade de cuidados pessoais cotidianos tem sido cada vez mais uma temática que não encontra resposta nas políticas públicas e sociais (GUIMARÃES, 2008; HITARA; GUIMARÃES, 2012; CRUZ, 2011). Essa demanda tem sido colocada na agenda pública, principalmente no que diz respeito 
às pessoas com deficiência, às pessoas idosas e crianças em creches públicas (CAMARANO, 2012; SORJ; FONTES, 2012). No entanto, embora muitas pessoas em sofrimento mental enfrentem os mesmos desafios cotidianos e necessitem de cuidados diários no ambiente do lar assim como crianças, idosos e pessoas com deficiência, esse não tem sido um público considerado como objeto de intervenções das ações públicas no debate contemporâneo sobre cuidado.

Não ter cuidador traz uma carga adicional para as famílias, de modo geral, e para as mulheres, de modo particular. Pois no interior das famílias, tal atribuição do cuidado, sem amparo de políticas públicas, pode reproduzir desigualdades e opressão nas dinâmicas familiares (KITTAY, 1998; NUSSBAUM, 2006). As pressões inerentes ao cotidiano e às tarefas das mulheres de cuidados não remunerados foram agravadas pela tendência à estabilização do emprego desse público nas últimas décadas. Antes, o emprego das mulheres tinha oscilação com as variações dos ciclos econômicos e da vida familiar, que provocavam sucessivas entradas e saídas das mulheres do mercado de trabalho; nas últimas décadas, o vínculo delas com o trabalho remunerado tem se estabilizado (SORJ; FONTES, 2012). Entre 1993 e 1999, a participação de mulheres com filhos dependentes no mercado de trabalho aumentou de 52\% para 58\% (PNAD, 2010). Em 2007, em pesquisa na região metropolitana de Belo Horizonte, foi levantado que a responsabilidade pelo cuidado dispensado às pessoas com deficiência fica a cargo, quase sempre, de membros da família residentes no domicílio. Do conjunto de cuidadores, $91 \%$ se enquadram nessa categoria (SOUZA; CARNEIRO, 2007). Não dispor de cuidador por meio de políticas públicas adequadas, deixando tal responsabilidade recair sobre os familiares, pode ser um fator impeditivo da desinternação dos indivíduos em medida de segurança.

O estudo de José Moreira Souza e Ricardo Carneiro (2007) demonstrou também a relação entre cuidados oferecidos pela família de uma pessoa com deficiência e renda. Quanto mais baixa a renda familiar da pessoa com deficiência, mais ela está propensa a receber cuidados cotidianos por cuidadores da própria família. Apenas com famílias com renda per capita entre 5 e 8 salários mínimos o percentual de cuidadores da própria família cai para $81 \%$, o que denota a participação, mesmo que tímida, de cuidadores particulares (SOUZA; CARNEIRO, 2007). A relação entre mulheres pobres e participação no mercado de trabalho é intrínseca: enquanto a taxa de participação de mulheres em domicílios com crianças até seis anos pertencentes aos $40 \%$ mais ricos aumentou cerca de 20 pontos percentuais entre 1993 e 1999, nos quintos mais pobres, o crescimento foi bem menor, sendo que no primeiro quinto 
houve até uma diminuição da inserção das mulheres no mercado de trabalho (SORJ; FREITAS, 2012). Para Bila Sorj e Adriana Fontes, "a carência de mecanismos que permitam desfamiliarizar os cuidados ajuda a perpetuar a pobreza, uma vez que limita a inserção das mulheres no mercado de trabalho e, portanto, maior renda familiar” (2012, p. 107). Esse cenário de famílias pobres, mulheres no mercado de trabalho e falta de políticas públicas de cuidado pode ser outro fator que influencia na não desinternação de indivíduos em medida de segurança quando não há redes de suporte para receber os indivíduos durante a desinternação.

A Tabela 3 demonstra a conjugalidade dos pacientes em medidas de segurança dos ECTP:

Tabela 3 Situação conjugal dos indivíduos esquecidos e dos em medida de segurança

\begin{tabular}{lcrrr}
\multicolumn{1}{c}{ Situação conjugal } & Esquecidos & \multicolumn{2}{c}{ MS } \\
Casado & 59 & $8 \%$ & 184 & $8 \%$ \\
Divorciado & 35 & $5 \%$ & 93 & $4 \%$ \\
Viúvo & 20 & $3 \%$ & 29 & $\mathbf{7 8 \%}$ \\
Solteiro & 578 & $78 \%$ & 1737 & $5 \%$ \\
Amasiado & 24 & $3 \%$ & 119 & $\mathbf{2 \%}$ \\
Sem informação & 25 & $3 \%$ & 53 & $\mathbf{1 0 0 \%}$ \\
& & & & $\mathbf{2 2 1 5}$ \\
Fonte: Pesquisa: A custódia e o tratamento psiquiátrico no Brasil: censo 2011. Ministério da Justiça/Anis: \\
Instituto de Bioética, Direitos Humanos e Gênero.
\end{tabular}

Em um cenário bem próximo ao cenário total da população em ECTPs, entre os indivíduos em medida de segurança há uma grande concentração de solteiros, 78\% (1.737). Entre os esquecidos, o percentual também é de $78 \%$ (578). O percentual de casados também é o mesmo nas duas populações: $8 \%$ (184) em medida de segurança e 8\% (59) entre os esquecidos dos manicômios judiciários. É um traço comum a situação de solteiros entre os indivíduos em sofrimento mental que estão nos manicômios judiciários. É arriscado afirmar que uma maior concentração de solteiros entre os indivíduos em medida de segurança poderia dificultar seu processo de desinternação, dada a ausência de apoio dos cônjuges. Mais importante do que conjecturar essa causalidade difícil de ser estabelecida é o fato de que uma maior quantidade de solteiros na população em medida de segurança pode ser explicada pelas restrições de participação social que os indivíduos em sofrimento mental experimentam antes de viverem reclusos. Restrição de participação na vida comunitária e social reduz as relações afetivas, o que leva a esse perfil conjugal. 
A Tabela 4 é sobre cor/raça da população em medidas de segurança:

Tabela 4 Cor da pele/raça ${ }^{6}$ dos indivíduos esquecidos e dos em medida de segurança

\begin{tabular}{|c|c|c|c|c|}
\hline Cor/Raça & \multicolumn{2}{|c|}{ Esquecidos } & \multicolumn{2}{|c|}{ MS } \\
\hline Amarelo & 1 & $0 \%$ & 5 & $0 \%$ \\
\hline Branco & 324 & $44 \%$ & 993 & $45 \%$ \\
\hline Indígena & 0 & $0 \%$ & 2 & $0 \%$ \\
\hline Parda & 207 & $28 \%$ & 646 & $29 \%$ \\
\hline Preta & 120 & $16 \%$ & 298 & $13 \%$ \\
\hline Outra & 9 & $1 \%$ & 20 & $1 \%$ \\
\hline Sem informação & 80 & $11 \%$ & 251 & $11 \%$ \\
\hline & 741 & $100 \%$ & 2215 & $100 \%$ \\
\hline
\end{tabular}

Fonte: Pesquisa: A custódia e o tratamento psiquiátrico no Brasil: censo 2011. Ministério da Justiça/Anis:Instituto de Bioética, Direitos Humanos e Gênero.

Apesar do alto número de pacientes nos ECTPs sem informações de cor da pele/raça recuperadas no estudo censitário (11\% em ambos os grupos), há uma distribuição próxima entre a população branca e a população negra. Entre os indivíduos em medida de segurança, 45\% (993) são brancos e 42\% (944) são pretos e pardos. Entre os esquecidos, estão 44\% (324) brancos e $44 \%$ (327) pretos e pardos.

A desigualdade social em função de raça é um dado histórico no cenário brasileiro (OSÓRIO, 2009). A busca por explicar as relações entre raça e ausência de oportunidades é constante na literatura nacional, o que vem demonstrando o processo histórico de acumulação de desvantagens econômicas e sociais da população negra (OSÓRIO, 2009). Nesse sentido, é possível perceber o quanto o universo dos manicômios judiciários pode reproduzir desigualdades pelos acúmulos de desvantagens resultantes dos obstáculos para acesso à educação, ao trabalho, à renda e às demais oportunidades que potencializam a autonomia dos indivíduos.

A Tabela 5 demonstra a escolaridade dos indivíduos em medida de segurança nos ECTPs do país:

\footnotetext{
${ }^{6}$ De acordo com as informações acerca da metodologia utilizada no estudo censitário (DINIZ, 2012), as informações sobre a raça ou cor da pele da população dos ECTP foram recuperadas e sistematizadas de acordo com as classificações utilizadas pelo Instituto Brasileiro de Geografia e Estatística - IBGE.
} 
Tabela 5 Escolaridade ${ }^{7}$ dos indivíduos esquecidos e dos em medida de segurança

\begin{tabular}{lrrrr}
\multicolumn{1}{c}{ Escolaridade } & Esquecidos & & \multicolumn{2}{c}{ MS } \\
Analfabeto & 208 & $28 \%$ & 517 & $23 \%$ \\
Fundamental incompleto & 337 & $45 \%$ & 996 & $45 \%$ \\
Fundamental & 85 & $11 \%$ & 320 & $14 \%$ \\
Médio & 32 & $4 \%$ & 130 & $6 \%$ \\
Superior & 3 & $0 \%$ & 18 & $1 \%$ \\
Pós-Graduação & 0 & $0 \%$ & 1 & $0 \%$ \\
Sem informação & 76 & $10 \%$ & 233 & $11 \%$ \\
& & & & $\mathbf{1 0 0 \%}$
\end{tabular}

Fonte: Pesquisa: A custódia e o tratamento psiquiátrico no Brasil: censo 2011. Ministério da Justiça/Anis: Instituto de Bioética, Direitos Humanos e Gênero.

De um modo bem semelhante ao total da população dos ECTPs, a baixa escolaridade é um traço comum à população em medida de segurança e à população dos esquecidos. Na metodologia do estudo censitário, houve uma escolha por registrar os primeiros anos do processo de alfabetização no item "fundamental incompleto" para acrescentar, à população que jamais teve a oportunidade de frequentar a escola, aqueles que apenas inicialmente o fizeram (DINIZ, 2012). Dessa forma, o ensino fundamental incompleto é o que comumente se classifica como analfabetismo funcional. Assim, somando as taxas de analfabetismo com os primeiros anos de estudo, registrados no item ensino fundamental incompleto, verifica-se que $68 \%$ (1.513) dos indivíduos em medida de segurança e 73\% (545) dos esquecidos são analfabetos ou frequentaram a escola apenas de forma inicial. Na população em medida de segurança e na população dos esquecidos, há respectivamente $6 \%$ e $4 \%$ de indivíduos com o ensino médio completo. Entre os esquecidos, há apenas 3 indivíduos com ensino superior, número que chega a 18 entre os demais em medida de segurança. Esses dados dão uma dimensão dos desafios colocados às políticas sociais no que diz respeito à garantia de proteção social e promoção da cidadania aos indivíduos em sofrimento mental na relação com as políticas de educação. A inclusão na vida social, comunitária e familiar depende da promoção da autonomia dos indivíduos que, em suas trajetórias antes de chegarem aos manicômios judiciários, têm um acúmulo de impedimentos que não lhes permitiu frequentar a escola no tempo adequado.

A Tabela 6 indica as profissões dos indivíduos em medidas de segurança dos manicômios judiciários:

\footnotetext{
${ }^{7}$ De acordo com as informações acerca da metodologia utilizada no estudo censitário (DINIZ, 2012), as informações sobre a escolaridade da população dos ECTP foram recuperadas e sistematizadas de acordo com as classificações utilizadas pelo Instituto Brasileiro de Geografia e Estatística - IBGE.
} 
Tabela 6 Profissão ${ }^{8}$ dos indivíduos esquecidos e dos em medida de segurança

\begin{tabular}{|c|c|c|c|c|}
\hline Profissão & \multicolumn{2}{|c|}{ Esquecidos } & \multicolumn{2}{|c|}{ MS } \\
\hline Forças armadas, militares etc & 2 & $0 \%$ & 14 & $1 \%$ \\
\hline Ciências e artes & 9 & $1 \%$ & 26 & $1 \%$ \\
\hline Técnico nível médio & 3 & $0 \%$ & 12 & $1 \%$ \\
\hline Serviços administrativos & 3 & $0 \%$ & 14 & $1 \%$ \\
\hline Comércio em lojas e mercados & 91 & $12 \%$ & 318 & $14 \%$ \\
\hline Agropecuários, florestais e pesca & 134 & $18 \%$ & 391 & $18 \%$ \\
\hline Serviços industriais & 196 & $26 \%$ & 530 & $24 \%$ \\
\hline Reparação e manutenção & 21 & $3 \%$ & 54 & $2 \%$ \\
\hline Profissão não listada & 43 & $6 \%$ & 101 & $5 \%$ \\
\hline Aposentado & 34 & $5 \%$ & 77 & $3 \%$ \\
\hline Sem profissão & 117 & $16 \%$ & 359 & $16 \%$ \\
\hline Autônomo & 6 & $1 \%$ & 47 & $2 \%$ \\
\hline Sem informação & 82 & $11 \%$ & 272 & $12 \%$ \\
\hline Total & 741 & $100 \%$ & 2215 & $100 \%$ \\
\hline
\end{tabular}

Fonte: Pesquisa: A custódia e o tratamento psiquiátrico no Brasil: censo 2011. Ministério da Justiça/Anis:Instituto de Bioética, Direitos Humanos e Gênero.

Coerentemente com a baixa escolaridade dos indivíduos em medida de segurança, há uma concentração de pessoas sem profissão ou em ocupações que não exigem qualificação técnica ou educacional nos ECTPs. Entre os indivíduos em medida de segurança, 16\% (359) não tinham profissão, percentual idêntico ao identificado entre os esquecidos 16\% (117). Trabalhadores do comércio e do meio rural somavam $42 \%$ (709) dos indivíduos em medida de segurança e 30\% (225) dos esquecidos. Estas últimas são demarcadamente ocupações sem exigências técnicas ou educacionais para sua formação. Houve também uma concentração de trabalhadores de serviços ligados ao ramo industrial, com 24\% (530) dos indivíduos em medida de segurança e 26\% (196) dos esquecidos. Apesar de ainda baixa e por relacionar-se a serviços industriais, e não exatamente profissões técnicas e qualificadas do ramo industrial, essa maior concentração em serviços industriais pode ser explicada pelo fato de que as maiores populações dos manicômios judiciários estão exatamente nas regiões mais industrializadas do país, como Sudeste (Minas Gerais, Rio de Janeiro e São Paulo) e Sul (Rio Grande do Sul e Paraná).

Em 2013, o Programa Nacional de Acesso ao Ensino Técnico e Emprego (Pronatec), do Ministério da Educação, passou a oferecer vagas em mais de 600 cursos técnicos gratuitos para presos e egressos de todo o sistema penitenciário brasileiro (BRASIL, 2014a). Essa é

\footnotetext{
${ }^{8}$ De acordo com as informações acerca da metodologia utilizada no estudo censitário (DINIZ, 2012), as informações sobre profissão e ocupações da população dos ECTP foram recuperadas e sistematizadas de acordo com a Classificação Brasileira de Ocupações - CBO.
} 
uma importante iniciativa para a promoção da autonomia dos pacientes em medida de segurança na fase da desinternação. A intersetorialidade entre as políticas de segurança pública, de assistência social, de educação e de trabalho e emprego oferece alternativas para ampliar a proteção social a essa população, o que favorece sobremaneira a emancipação e contribui para a liberdade condicional, bem como a inclusão social de modo geral.

Em um Estado democrático de direito, a proteção social ocorre de duas principais maneiras: por meio da inserção do indivíduo no mundo do trabalho e por meio de políticas de seguridade social, como a de assistência social (CASTEL, 2005). Na sociedade capitalista, o trabalho passa a assumir não uma simples técnica de produção, mas um suporte privilegiado de inscrição na estrutura social, havendo uma forte correlação entre o lugar ocupado na divisão social do trabalho e a participação nas redes de sociabilidade e nos sistemas que protegem um indivíduo diante dos acasos da existência (CASTEL, 1995). Assim, a associação entre o trabalho estável e a inserção relacional sólida caracteriza uma área de integração, ao passo que, inversamente, a ausência de participação em qualquer atividade produtiva e o isolamento relacional resultam em efeitos como a pobreza e a desproteção social (CASTEL, 1995). Para Robert Castel (1995), a vulnerabilidade social é, portanto, uma zona intermediária e instável, que conjuga a precariedade do trabalho e a fragilidade dos suportes que levam a uma atenção das necessidades sociais dos indivíduos.

As pessoas em sofrimento mental enfrentam duplamente os efeitos dessa vulnerabilidade social. Primeiro, por não serem reconhecidas socialmente como sujeitos produtivos, dada a dificuldade de inserção no mercado de trabalho. E segundo, pela dificuldade e mesmo impossibilidade de garantirem sua autonomia econômica, social e simbólica devido às suas condições de saúde, o que resulta em seu isolamento da sociedade produtiva. Ou seja, a noção de proteção social a ser garantida ao sujeito quando ele passa a fazer parte das relações de trabalho, no caso das pessoas em sofrimento mental, torna-se frágil pelas especificidades desse grupo populacional. Em paralelo às fragilidades dessa população, está o fato de esses indivíduos terem cometido crime, da dependência institucional que muitos desenvolvem e das demandas específicas em assistência em saúde, o que dificulta ainda mais o processo de recuperação da autonomia proporcionado por uma ocupação e um trabalho remunerado.

O trabalho é um elemento central que determina os suportes de inscrição social dos indivíduos. Isto é, o trabalho não define apenas a autonomia dos sujeitos e a proteção a suas famílias por meio da remuneração e proteções ligadas aos direitos trabalhistas. As formas de 
proteção social numa sociedade capitalista dependem sobremaneira da organização social, que tem no trabalho, o elemento definidor da sociabilidade humana, dos intercâmbios sociais, econômicos e simbólicos que retratam os princípios que sustentam a sociedade produtiva. Até mesmo para o conjunto de políticas sociais que promovem a cidadania, como mecanismos complementares ao que o mundo do trabalho seja capaz de oferecer, a chamada propriedade social depende para sua manutenção e reprodução da vinculação ao trabalho (CASTEL, 2005). Isto é, as políticas sociais estruturam-se como elementos que oferecem suporte ao mundo do trabalho, mas são direcionadas para reforçar a matriz estruturante do trabalho em nossa sociedade produtiva. É como se as políticas sociais surgissem como complemento às proteções que o trabalho não seja capaz de alcançar. Não para substituir a centralidade dele e, sim, reforçá-la (CASTEL, 2005; BOSCHETTI, 2006). Nas sociedades capitalistas, o trabalho não assumiu somente a centralidade do modelo de produção, mas uma trama na qual a sociabilidade humana vincula-se estritamente ao trabalho, mesmo quando não está presente no cotidiano do indivíduo que tem suas necessidades básicas atendidas pelas políticas sociais que se modelam sempre a partir do universo do trabalho.

Os sujeitos não inscritos nos suportes de proteção social, que têm no trabalho a centralidade, podem ter acesso às necessidades básicas por meio das políticas sociais (PEREIRA, 2000). No entanto, sempre serão remetidos à matriz do trabalho. É o caso do acesso aos direitos sociais de cidadania via políticas sociais acabarem se materializando, principalmente quando a inabilidade ou incapacidade para o trabalho esteja presente (DINIZ; BARBOSA; MEDEIROS, 2010; SANTOS, 2010). Ou quando direitos sociais advindos das políticas de proteção e assistência social são caracterizados como de categoria rebaixada para reforçar a valorização do exercício do trabalho produtivo (SILVA, SILVA, 1998). Grupos populacionais específicos cujas características os particularizam em relação à sociedade produtiva, tais como crianças, idosos, pessoas com deficiência, pessoas com doenças permanentes ou temporárias, terão acesso aos sistemas de proteção social distinto daqueles sujeitos produtivos inseridos no mundo do trabalho.

As pessoas em sofrimento mental encontram desafios singulares para se inserirem no mundo do trabalho. As barreiras para acesso à educação certamente têm influência para a baixa qualificação educacional e profissional apresentada pelos indivíduos em cumprimento de medida de segurança. No entanto, as particularidades advindas do sofrimento mental, como as necessidades de assistência, os momentos de crises que necessitam de cuidados mais intensos e as constantes internações certamente têm impactos para as características que se 
esperam do sujeito produtivo para o mundo do trabalho. No caso dos indivíduos em medida de segurança, o simulacro do corpo produtivo que se espera para atender as expectativas do mundo do trabalho ainda é mais distante. Se, de um lado, as proteções oferecidas pela inserção no mundo do trabalho são escassas, a necessidade de políticas sociais se intensifica, tornando ainda mais desafiante a articulação das políticas de assistência social, saúde mental, educação, trabalho e emprego voltadas para os indivíduos em sofrimento mental que cometem crimes.

\subsection{Os diagnósticos ${ }^{9}$, os exames e os crimes na relação com a família}

Certamente uma das principais prerrogativas dos ECTPs é oferecer tratamento adequado às especificidades dos pacientes em cumprimento de medida de segurança. Como o paradigma de atenção em saúde mental no Brasil, desde 2001, pressupõe a liberdade, a assistência oferecida em serviços substitutivos não asilares e um trabalho integrado com as famílias, comunidades e redes sociais dos pacientes, a restrição de liberdade das medidas de segurança impõe várias limitações a esse modelo. Desse modo, é preciso atentar para alternativas que incorporem as diretrizes da Lei 10.216 ao universo do cumprimento das medidas de segurança, como já tem sido incentivado pelas resoluções do Conselho Nacional de Política Criminal e Penitenciária, órgão máximo de controle social e democrático da política penitenciária brasileira (ver capítulo anterior).

A Tabela 7 explicita os diagnósticos da população em medida de segurança dos ECTP brasileiros:

\footnotetext{
${ }^{9}$ De acordo com as informações acerca da metodologia utilizada no estudo censitário (DINIZ, 2012), as informações sobre diagnósticos da população dos ECTP foram recuperadas e sistematizadas de acordo com a Classificação Internacional de Doenças e Problemas relacionados à saúde, em sua $10^{\text {a }}$ edição - CID-10.
} 
Tabela 7 Diagnósticos dos indivíduos esquecidos e dos indivíduos em medida de segurança

\begin{tabular}{|c|c|c|c|c|}
\hline Diagnóstico & \multicolumn{2}{|c|}{ Esquecidos } & \multicolumn{2}{|c|}{ MS } \\
\hline Retardo mental & 125 & $17 \%$ & 343 & $15 \%$ \\
\hline Epilepsia & 29 & $4 \%$ & 71 & $3 \%$ \\
\hline Esquizofrenia & 353 & $48 \%$ & 892 & $40 \%$ \\
\hline Transtorno de personalidade & 33 & $4 \%$ & 118 & $5 \%$ \\
\hline Transtornos da preferência sexual & 7 & $1 \%$ & 32 & $1 \%$ \\
\hline Transtorno afetivo uni ou bipolar & 25 & $3 \%$ & 70 & $3 \%$ \\
\hline Transtornos mentais devido ao uso de álcool e outras drogas & 85 & $11 \%$ & 241 & $11 \%$ \\
\hline Transtornos mentais orgânicos & 13 & $2 \%$ & 39 & $2 \%$ \\
\hline Outros & 2 & $0 \%$ & 5 & $0 \%$ \\
\hline Sem informação & 69 & $9 \%$ & 404 & $18 \%$ \\
\hline Total & 741 & $100 \%$ & 2215 & $100 \%$ \\
\hline
\end{tabular}

Fonte: Pesquisa: A custódia e o tratamento psiquiátrico no Brasil: censo 2011. Ministério da Justiça/Anis: Instituto de Bioética, Direitos Humanos e Gênero.

A distribuição dos diagnósticos na população em medida de segurança e na população dos esquecidos dos manicômios judiciários é semelhante. A principal diferença está entre aqueles com esquizofrenia. Enquanto, na população dos esquecidos, $48 \%$ (353) têm esse diagnóstico, entre os demais pacientes em medida de segurança, esse percentual cai para $40 \%$ (892).

Também chama a atenção o alto índice de pessoas com retardo mental. Essa nomenclatura, cada vez mais em desuso - hoje, fala-se em deficiência intelectual ou mental - , acomete $17 \%$ (125) dos esquecidos e 15\% (343) dos demais em medida de segurança. Os desafios colocados ao funcionamento dos manicômios judiciários dizem respeito ao fato de que essa não é uma doença ou um transtorno para o qual deve haver, $a$ priori, tratamento médico, psiquiátrico ou psicológico. Trata-se de uma deficiência, isto é, uma condição cognitiva para a qual não cabe tratamento médico no sentido de superação do diagnóstico, embora, necessite de acompanhamentos médicos para condições decorrentes do quadro específico. O sistema de inimputabilidade brasileiro colocou essas duas situações (doença e deficiência) muito díspares entre aquelas que devem receber tratamento psiquiátrico obrigatório. Se o diagnóstico estiver correto para esse alto número de pessoas em medida de segurança com deficiência mental ou intelectual (é a segunda maior concentração depois da esquizofrenia), os ECTPs necessitam se adequar às demandas dessa população — que não precisa de tratamento psiquiátrico, mas de acompanhamento terapêutico, assistencial, pedagógico e educacional adequados para seu desenvolvimento com autonomia. 
A Tabela 8 enumera os crimes cometidos pelos indivíduos em medida de segurança que se encontravam nos ECTPs em 2011:

Tabela 8 Crimes cometidos pelos indivíduos esquecidos e pelos em medida de segurança

\begin{tabular}{lrrrr}
\multicolumn{1}{c}{$\quad$ Crime cometido* } & Esquecidos & MS \\
Contravenções penais & 10 & $1 \%$ & 16 & $1 \%$ \\
Crime de tortura & 2 & $0 \%$ & 3 & $0 \%$ \\
Crimes ambientais & 1 & $0 \%$ & 4 & $0 \%$ \\
Crimes contra a administração pública & 14 & $2 \%$ & 28 & $1 \%$ \\
Crimes contra a dignidade sexual & 94 & $13 \%$ & 348 & $16 \%$ \\
Crimes contra a fé pública & 0 & $0 \%$ & 5 & $0 \%$ \\
Crimes contra a honra & 0 & $0 \%$ & 4 & $0 \%$ \\
Crimes contra a incolumidade pública & 13 & $2 \%$ & 30 & $1 \%$ \\
Crimes contra a inviolabilidade do domicílio & 3 & $0 \%$ & 9 & $0 \%$ \\
Crimes contra a liberdade individual & 26 & $4 \%$ & 82 & $4 \%$ \\
Crimes contra a paz pública & 1 & $0 \%$ & 0 & $0 \%$ \\
Crimes contra a propriedade intelectual & 0 & $0 \%$ & 1 & $0 \%$ \\
Crimes contra a vida & 322 & $43 \%$ & 952 & $43 \%$ \\
Crimes contra o patrimônio & 220 & $30 \%$ & 659 & $30 \%$ \\
Crimes contra o respeito aos mortos & 4 & $1 \%$ & 9 & $0 \%$ \\
Crimes contra o sentimento religioso & 0 & $0 \%$ & 1 & $0 \%$ \\
Crimes da lei anti-drogas & 27 & $4 \%$ & 79 & $4 \%$ \\
Crimes do estatuto da criança e do adolescente & 0 & $0 \%$ & 3 & $0 \%$ \\
Crimes do estatuto do desarmamento & 7 & $1 \%$ & 33 & $1 \%$ \\
Crimes do estatuto do idoso & 0 & $0 \%$ & 1 & $0 \%$ \\
Lesões corporais & 69 & $9 \%$ & 149 & $7 \%$ \\
Outros & 21 & $3 \%$ & 23 & $1 \%$ \\
Periclitação da vida e da saúde & 2 & $0 \%$ & 3 & $0 \%$ \\
Rixa & 0 & $0 \%$ & 1 & $0 \%$ \\
Sem informação & 16 & $2 \%$ & 73 & $3 \%$
\end{tabular}

* É possível ter mais de um crime

Fonte: Pesquisa: A custódia e o tratamento psiquiátrico no Brasil: censo 2011. Ministério da Justiça/Anis: Instituto de Bioética, Direitos Humanos e Gênero.

Os principais crimes cometidos pelas pessoas em medida de segurança são os crimes contra o patrimônio e contra a vida. Entre os crimes contra o patrimônio, estão furto, roubo, tentativa de furto e tentativa de roubo. Entre os crimes contra a vida, estão as tentativas de homicídio e os homicídios. A mesma porcentagem de crimes contra a vida e crimes contra o patrimônio foi identificada entre os indivíduos esquecidos, 43\% (322) e 30\% (220), respectivamente, e os demais indivíduos em medida de segurança, $43 \%$ (952) e 30\% (659). Os 
crimes contra a dignidade sexual, como estupro, tentativa de estupro, atentado violento ao pudor e tentativa de atentado violento ao pudor, foram cometidos por 13\% (94) dos esquecidos e $16 \%$ (348) dos demais em medida de segurança.

$\mathrm{O}$ quarto crime mais cometido foram as lesões corporais. Entre os esquecidos, esse crime foi cometido por $9 \%$ (69) e, entre os demais em medida de segurança, por 7\% (149) dos pacientes.

A Tabela 9 apresenta a ocorrência de recidiva (reincidência) entre os que cumprem medida de segurança.

Tabela 9 Recidiva dos indivíduos esquecidos e dos em medida de segurança

\begin{tabular}{|c|c|c|c|c|}
\hline Recidiva & \multicolumn{2}{|c|}{ Esquecidos } & \multicolumn{2}{|c|}{ MS } \\
\hline Sim & 232 & $31 \%$ & 540 & $24 \%$ \\
\hline Não & 479 & $65 \%$ & 1530 & $69 \%$ \\
\hline Sem informação & 30 & $4 \%$ & 145 & $7 \%$ \\
\hline Total & 741 & $100 \%$ & 2215 & $100 \%$ \\
\hline
\end{tabular}

Fonte: Pesquisa: A custódia e o tratamento psiquiátrico no Brasil: censo 2011. Ministério da Justiça/Anis: Instituto de Bioética, Direitos Humanos e Gênero.

Dos esquecidos, 31\% (232) são recidivantes, isto é, haviam cometido crimes anteriores ao que levou à medida de segurança recente. Entre os demais em medida de segurança, o índice de recidivantes é ainda menor, 24\% (540). Dados de 2013 revelam que a reincidência entre a população penitenciária brasileira é de pouco mais de 47\% (PRADO, 2012). Em termos brutos, a recidiva da população dos manicômios judiciários é bem menor do que a da população do sistema penitenciário comum, este é um dado que questiona o pânico moral no imaginário social a respeito da periculosidade dos indivíduos em sofrimento mental que cometem crimes.

A próxima tabela demonstra as concentrações dos crimes cometidos contra membros da família. 
Tabela 10 Crimes contra a família dos esquecidos e dos em medida de segurança

\begin{tabular}{|c|c|c|c|c|}
\hline Crime contra a família & \multicolumn{2}{|c|}{ Esquecidos } & \multicolumn{2}{|c|}{ MS } \\
\hline Sim & 218 & $29 \%$ & 568 & $26 \%$ \\
\hline Não & 467 & $63 \%$ & 1451 & $66 \%$ \\
\hline Sem informação & 56 & $8 \%$ & 196 & $9 \%$ \\
\hline Total & 741 & $100 \%$ & 2215 & $100 \%$ \\
\hline
\end{tabular}

Fonte: Pesquisa: A custódia e o tratamento psiquiátrico no Brasil: censo 2011. Ministério da Justiça/ Anis: Instituto de Bioética, Direitos Humanos e Gênero.

Há poucas diferenças entre os esquecidos e os demais em medida de segurança no que diz respeito ao pertencimento das vítimas à família. Entre os esquecidos, 29\% (218) cometeram crimes contra a família, e entre os demais em medida de segurança, $26 \%$ (568). A despeito das pequenas diferenças entre os dois grupos, o importante a ser ressaltado é o alto número de crimes contra o grupo familiar dos pacientes em medida de segurança. Como já salientado, essa característica tão presente entre os indivíduos em medida de segurança indica o quanto os procedimentos para a desinternação devem levar em consideração essa relação conflituosa entre o indivíduo e sua família.

As famílias têm um papel importante no momento da desinternação por dois principais motivos. O primeiro é oferecer condições para que os indivíduos continuem em tratamento. Como já discutido, esse critério tem sido inclusive utilizado por alguns psiquiatras como capaz de determinar a cessação da periculosidade dos indivíduos (MECLER, 2010). O segundo é o oferecimento de apoio para moradia, dada a ausência de políticas que atendam essa demanda dos pacientes (ver capítulo anterior). Para tal situação, não há política específica no âmbito da segurança pública ou da política nacional voltada para a população penitenciária (BRASIL, 2003). Os desafios na fase de desinternação que envolvem o trabalho com a família ficam a cargo das Varas de Execuções Penais ou Criminais ligadas aos Tribunais de Justiça em cada unidade da Federação.

A Portaria Interministerial $n^{\circ} 1777$, de 09 de setembro de 2003, que instituiu o Plano Nacional de Saúde no Sistema Penitenciário, é fruto de um trabalho matricial construído com a participação de diversas áreas técnicas dos Ministérios da Saúde e da Justiça e com a participação do Conselho Nacional de Secretários de Saúde, do Conselho Nacional de Secretários Municipais de Saúde e do Conselho Nacional de Política Criminal e Penitenciária (BRASIL, 2003). O Plano envolve ações, dentre outras, de campanhas de vacinação, direito a visita íntima, distribuição de kits de medicamentos da farmácia básica, incluindo a 
distribuição de preservativos masculinos e medicamentos específicos para gestantes, inclusão da população penitenciária na política de planejamento familiar. Tais ações são desenvolvidas por equipes multiprofissionais, compostas minimamente por médico, cirurgião-dentista, psicólogo, assistente social, enfermeiro e auxiliar de enfermagem, com ações voltadas para prevenção, promoção e tratamento de agravos em saúde, primando pela atenção integral em saúde bucal, saúde da mulher, doenças sexualmente transmissíveis, AIDS e hepatites virais, saúde mental, controle da tuberculose, hipertensão e diabetes, hanseníase, assistência farmacêutica básica, imunizações e coletas de exames laboratoriais (BRASIL, 2003).

Esse Plano de 2003 se configura em importante etapa para a concretização de medias que materializem o direito à saúde da população penitenciária. No entanto, não há no Plano menções específicas às necessidades dos indivíduos em medidas de segurança, tampouco na fase de desinternação condicional. Essa ausência de políticas para essa situação torna frágil a desinternação dos indivíduos em medida de segurança, o que pode violar um conjunto de direitos dos pacientes em medida de segurança.

A Tabela 11 registra o tempo de internação:

Tabela 11 Tempo de internação dos indivíduos esquecidos e dos em medida de segurança

\begin{tabular}{lrrrr}
\multicolumn{1}{c}{ Tempo da internação } & Esquecidos & \multicolumn{3}{c}{ MS } \\
Menos de um ano & 23 & $3 \%$ & 248 & $11 \%$ \\
1 a 5 anos & 306 & $41 \%$ & 1119 & $51 \%$ \\
6 a 10 anos & 150 & $20 \%$ & 387 & $17 \%$ \\
11 a 15 anos & 94 & $13 \%$ & 126 & $6 \%$ \\
16 a 20 anos & 61 & $8 \%$ & 59 & $3 \%$ \\
21 a 25 anos & 33 & $4 \%$ & 30 & $1 \%$ \\
26 a 30 anos & 12 & $2 \%$ & 13 & $1 \%$ \\
Acima de 30 anos & 3 & $0 \%$ & 6 & $10 \%$ \\
Sem informação & 59 & $8 \%$ & 227 & \\
& & & & $\mathbf{1 0 0 \%}$
\end{tabular}

Fonte: Pesquisa: A custódia e o tratamento psiquiátrico no Brasil: censo 2011. Ministério da Justiça/Anis: Instituto de Bioética, Direitos Humanos e Gênero.

De modo geral, a maior concentração é no período entre 1 e 5 anos de internação. Nesse intervalo, estão $51 \%$ (1.119) dos indivíduos em medida de segurança e $41 \%$ (306) dos esquecidos. A diferença entre as duas populações explica a duração prolongada das internações dos indivíduos esquecidos. Além disso, as faixas entre 11 e 15 anos de internação, entre 16 e 20 anos e entre 21 e 25 anos apresentam maior concentração dos indivíduos 
esquecidos, $13 \%$ (94), $8 \%$ (61) e 4\% (33), respectivamente. Nessas três faixas, a concentração dos demais indivíduos em medida de segurança é bem menor, 6\% (126), 3\% (59) e 1\% (30).

No estudo censitário publicado em 2012, foi demonstrado que 56\% (1.648) das pessoas em medida de segurança do país estavam internadas havia mais tempo do que estariam se tivessem recebido a pena mínima em abstrato para a infração penal cometida (DINIZ, 2012). Isto é, comparativamente a uma pessoa que cumpre uma pena comum por um crime comum, as pessoas em medida de segurança ficam em restrição de liberdade por mais tempo. Esse é um importante dado sobre o funcionamento das medidas de segurança que oferecem tratamento psiquiátrico obrigatório. Para os objetivos desta tese, o que esse dado alerta é que, à medida que o cumprimento do tratamento psiquiátrico obrigatório se prolonga nos manicômios judiciários, a possibilidade de desinternação com inclusão na família, na comunidade e no mundo do trabalho diminui.

A Tabela 12 apresenta a quantidade de internações dos indivíduos nos manicômios judiciários.

Tabela 12 Número de internações em ECTP dos indivíduos esquecidos e dos em medidas de segurança

\begin{tabular}{lcrrr}
\multicolumn{1}{c}{ Número de internações } & Esquecidos & \multicolumn{2}{c}{ MS } & 76\% \\
Primeira internação & 482 & $65 \%$ & 1684 & $16 \%$ \\
Duas internações & 172 & $23 \%$ & 365 & $6 \%$ \\
Três ou mais internações & 77 & $10 \%$ & 136 & $1 \%$ \\
Sem informação & 10 & $1 \%$ & 30 & $\mathbf{1 0 0 \%}$
\end{tabular}

Fonte: Pesquisa: A custódia e o tratamento psiquiátrico no Brasil: censo 2011. Ministério da Justiça/Anis: Instituto de Bioética, Direitos Humanos e Gênero.

A maioria dos pacientes está na primeira internação em ECTP. Entre os esquecidos, a proporção de pacientes na primeira internação é de $65 \%$ (482), ao passo que, entre os demais pacientes em medida de segurança, 76\% (1.684) estão na primeira internação. Os que estão na segunda internação representam 23\% (172) dos indivíduos esquecidos dos manicômios judiciários e 16\% (136) dos demais em medida de segurança.

5.3 Os esquecidos e a internação: o interior dos manicômios e as características pessoais dos pacientes não definem o prolongamento da internação

De todas as características sociodemográficas analisadas entre os indivíduos esquecidos dos manicômios judiciários e os demais em medida de segurança, nenhuma 
particulariza os indivíduos esquecidos a ponto de explicar sua situação de abandono. Há uma semelhança entre as duas populações em praticamente todos os quesitos dos dados sociodemográficos. O que a comparação demonstrou, na verdade, foi uma soma entre vários indicadores de vulnerabilidades sociais experimentadas pelos indivíduos em medida de segurança. Todos os dados levantados e analisados, tais como idade, sexo, cor da pele ou raça, escolaridade e profissão dos indivíduos em medida de segurança, delineiam o perfil de uma população talvez das mais vulnerabilizadas socialmente entre aquelas sob a tutela do Estado.

O mesmo pode ser dito dos dados relacionados aos diagnósticos, que são praticamente idênticos na população dos esquecidos e dos demais em medida de segurança. Um aspecto já mencionado que chama a atenção é o fato de a segunda maior prevalência nas duas populações ser de retardo mental (deficiência mental/intelectual). De modo geral, não há tratamento psiquiátrico para deficiências mentais. Doenças e transtornos mentais ao lado de deficiências mentais/intelectuais em um mesmo equipamento público, recebendo os mesmos tipos de assistência médica, pode não surtir efeitos para o desenvolvimento de habilidades e condições de retorno ao convívio social do paciente, depois de superadas as situações denominadas de periculosidade. Deficiência mental/intelectual requer acompanhamento especializado tanto terapêutico quanto pedagógico e assistencial. Os ECTPs não têm essa possibilidade nem nos quadros de profissionais, nem nos serviços prestados aos pacientes em medida de segurança.

No que diz respeito aos crimes cometidos, também há semelhança entre os indivíduos chamados aqui de esquecidos dos manicômios judiciários e os demais em medida de segurança. Há prevalência de crimes contra a vida, seguida de crimes contra o patrimônio e, em terceiro lugar, crimes contra a dignidade sexual nas duas populações. Sobre os crimes cometidos contra membros da família, há uma pequena diferença entre os indivíduos esquecidos e os demais em medida de segurança. Entre os esquecidos, 29\% cometeram crimes contra a família e, entre os demais em medida de segurança, esse percentual cai para $26 \%$. Apesar de sutil, a diferença aponta que a relação entre crime e família pode se transformar em um limitador no momento da desinternação.

A Tabela 13 demonstra a distribuição dos esquecidos nos 26 ECTPs do país: 
Tabela 13 Distribuição dos esquecidos e dos demais em MS nos 26 ECTPS

\begin{tabular}{|c|c|c|c|c|c|}
\hline Município & Nome do ECTP & Esqu & cidos & $\mathbf{M}$ & \\
\hline Aracaju & $\begin{array}{l}\text { Hospital de Custódia e Tratamento Psiquiátrico de } \\
\text { Sergipe }\end{array}$ & 5 & $1 \%$ & 34 & $2 \%$ \\
\hline Barbacena & Hospital Psiquiátrico e Judiciário Jorge Vaz & 35 & $5 \%$ & 100 & $5 \%$ \\
\hline Belém & Hospital de Custódia e Tratamento Psiquiátrico & 2 & $0 \%$ & 71 & $3 \%$ \\
\hline Brasília & Ala Psiquiátrica & 14 & $2 \%$ & 69 & $3 \%$ \\
\hline Cariacica & $\begin{array}{l}\text { Hospital de Custódia e Tratamento Psiquiátrico } \\
\text { Unidade de Saúde Mental II do Presídio Pascoal }\end{array}$ & 12 & $2 \%$ & 28 & $1 \%$ \\
\hline Cuiabá & Ramos & 0 & $0 \%$ & 29 & $1 \%$ \\
\hline Curitiba & Complexo Médico Penal do Paraná & 75 & $10 \%$ & 364 & $16 \%$ \\
\hline Florianópolis & Hospital de Custódia e Tratamento Psiquiátrico & 31 & $4 \%$ & 74 & $3 \%$ \\
\hline Fortaleza & $\begin{array}{l}\text { Instituto Psiquiátrico Governador Stênio Gomes } \\
\text { Hospital de Custódia e Tratamento Psiquiátrico II }\end{array}$ & 23 & $3 \%$ & 29 & $1 \%$ \\
\hline Franco da Rocha & $\begin{array}{l}\text { de Franco da Rocha } \\
\text { Hospital de Custódia e Tratamento Psiquiátrico }\end{array}$ & 150 & $20 \%$ & 23 & $1 \%$ \\
\hline Franco da Rocha & Professor André Teixeira & 43 & $6 \%$ & 522 & $24 \%$ \\
\hline Ilha de Itamaracá & Hospital de Custódia e Tratamento Psiquiátrico & 61 & $8 \%$ & 142 & $6 \%$ \\
\hline João Pessoa & $\begin{array}{l}\text { Instituto de Psiquiatria Forense - IPF/ PB } \\
\text { Hospital de Toxicômanos Padre Wilson Vale da }\end{array}$ & 15 & $2 \%$ & 24 & $1 \%$ \\
\hline Juiz de Fora & $\begin{array}{l}\text { Costa } \\
\text { Centro Psiquiátrico Judiciário Pedro Marinho }\end{array}$ & 1 & $0 \%$ & 2 & $0 \%$ \\
\hline Maceió & $\begin{array}{l}\text { Suruagy } \\
\text { Hospital de Custódia e Tratamento Psiquiátrico do }\end{array}$ & 17 & $2 \%$ & 19 & $1 \%$ \\
\hline Manaus & $\begin{array}{l}\text { Amazonas } \\
\text { Unidade Psiquiátrica de Custódia e Tratamento de }\end{array}$ & 2 & $0 \%$ & 18 & $1 \%$ \\
\hline Natal & $\begin{array}{l}\text { Natal } \\
\text { Hospital de Custódia e Tratamento Psiquiátrico }\end{array}$ & 6 & $1 \%$ & 30 & $1 \%$ \\
\hline Niterói & Henrique Roxo & 32 & $4 \%$ & 81 & $4 \%$ \\
\hline Porto Alegre & $\begin{array}{l}\text { Instituto Psiquiátrico Forense Maurício Cardoso } \\
\text { Enfermaria da Unidade Prisional da Capital Ênio }\end{array}$ & 68 & $9 \%$ & 176 & $8 \%$ \\
\hline Porto Velho & Pinheiro & 4 & $1 \%$ & 24 & $1 \%$ \\
\hline Ribeirão das Neves & $\begin{array}{l}\text { Centro de Apoio Médico e Pericial } \\
\text { Centro de Tratamento e Dependência Química } \\
\text { Roberto Medeiros - Hospital Psiquiátrico Penal }\end{array}$ & 5 & $1 \%$ & 18 & $1 \%$ \\
\hline Rio de Janeiro & $\begin{array}{l}\text { Roberto Medeiros } \\
\text { Hospital de custódia e Tratamento psiquiátrico }\end{array}$ & 7 & $1 \%$ & 23 & $1 \%$ \\
\hline Rio de Janeiro & Heitor Carrilho & 72 & $10 \%$ & 43 & $2 \%$ \\
\hline Salvador & $\begin{array}{l}\text { Hospital de Custódia e Tratamento de Salvador } \\
\text { Hospital de Custódia e Tratamento Psiquiátrico Dr. }\end{array}$ & 24 & $3 \%$ & 26 & $1 \%$ \\
\hline Taubaté & Arnaldo Amado & 34 & $5 \%$ & 235 & $11 \%$ \\
\hline Teresina & Hospital Penitenciário Valter Alencar & 3 & $0 \%$ & 11 & $0 \%$ \\
\hline
\end{tabular}
Instituto de Bioética, Direitos Humanos e Gênero. 
Os maiores percentuais de indivíduos em condições de estar em liberdade, mas ainda reclusos, encontram-se no HCTP II de Franco da Rocha (SP), no HCTP de Curitiba (PR), no HCTP Heitor Carrilho (RJ) e no HCTP de Porto Alegre (RS). Os HCTPs de Franco da Rocha II, de Curitiba e de Porto Alegre são três dos maiores ECTPs do país em termos de população total. O terceiro ECTP com o maior percentual de esquecidos é o HCTP Heitor Carrilho. Uma informação importante a respeito desse HCTP, além do fato de ele ter sido o primeiro manicômio judiciário brasileiro, é que a direção do ECTP nomeia os indivíduos em condição de serem desinternados como "abrigados", por residirem no ECTP mesmo após o cumprimento de tratamento psiquiátrico obrigatório. O HCTP de Salvador possuía, em 2011, 24 indivíduos na condição de esquecidos, chamados nesse manicômio judiciário de "problema social". Os abrigados, os problemas sociais, os esquecidos apontam vestígios de uma instituição manicomial que não encontra mais correspondência com a dinâmica social a partir dos anos 1990 e 2000 na política de assistência social e de saúde mental.

Observando os cenários conjecturais em relação à população dos esquecidos e a rede de serviços substitutivos da saúde mental, percebe-se que os quatro estados que concentram a maior quantidade de indivíduos esquecidos nos manicômios judiciários - São Paulo, com $31 \%$ (227), Rio de Janeiro, com 15\% (111), Paraná, com 10\% (75), e Rio Grande do Sul, com 9\% (68) - também concentram uma rede relativamente estruturada dos serviços substitutivos da assistência em saúde mental. Os dois estados com a maior população de esquecidos, São Paulo e Rio de Janeiro, eram também os dois com a maior quantidade de Serviços Residenciais Terapêuticos em 2012: 285 em São Paulo e 131 no Rio de Janeiro (BRASIL, 2012). O terceiro estado com a maior população de esquecidos, o Paraná, estava em sexto lugar entre aqueles com a maior quantidade de residências terapêuticas, 25 em 2012 (BRASIL, 2012b). Já o Rio Grande do Sul, que tem a quarta maior população de esquecidos dos manicômios judiciários, estava em quinto lugar no país na quantidade de residências terapêuticas (BRASIL, 2012b). Apesar de os Serviços Residenciais Terapêuticos serem importantes equipamentos públicos para os pacientes em sofrimento mental que não têm laços familiares, é possível que tais equipamentos possam não estar adequados para receber pacientes de manicômios judiciários. Isso pode ajudar a compreender o fato de que, mesmo em estados com grande número desses serviços residenciais, tais equipamentos públicos não são suficientes para evitar o surgimento dos esquecidos dos manicômios judiciários.

Com a maior população de esquecidos, São Paulo era também o estado com a maior quantidade de CAPS em 2012, com 282 unidades (BRASIL, 2012a). O Rio de Janeiro, com a 
segunda maior população de esquecidos, era o quinto com mais CAPS, 111 em 2012 (BRASIL, 2012a). O Paraná, com a terceira maior população de esquecidos nos manicômios judiciários, era o sétimo em quantidade de CAPS, com 97 equipamentos (BRASIL, 2012a). E o Rio Grande do Sul, quarta maior população de esquecidos, era também o quarto estado com o maior número de CAPS em 2012, 147 (BRASIL, 2012a).

Além disso, um dado importante: apesar de possuir três ECTPs, nas cidades de Barbacena, Juiz de Fora e Ribeirão das Neves, Minas Gerais concentra apenas 6\% (41) dos esquecidos do país. Além de possuir a terceira maior quantidade de CAPS do Brasil, com 173 em 2012, e a terceira maior quantidade de Serviços Residenciais Terapêuticos, com 104 residências em 2012, o estado mineiro promove o Programa de Atenção Integral ao Paciente Judiciário (PAI-PJ), como analisado no capítulo anterior. O PAI-PJ certamente tem influência sobre a baixa ocorrência de indivíduos esquecidos nos três ECTPs do estado mineiro. Essa relação entre a rede de serviços substitutivos e a população dos esquecidos dos manicômios judiciários foi estabelecida aqui para que, de modo exploratório, se façam conexões que requerem aprofundamento em análises futuras. A ideia é verificar o quanto a estruturação dos serviços substitutivos da Lei da Reforma Psiquiátrica pode contribuir para o processo de desinternação dos indivíduos em medida de segurança.

Os serviços substitutivos podem ter papel decisivo na assistência e integração de ações para o momento da desinternação dos indivíduos em medida de segurança. Entretanto, apenas a existência dos serviços in natura da rede de saúde parece não ter influência direta sobre esses indivíduos em conflito com a lei no processo de desinternação — não evita o surgimento dos esquecidos dos manicômios judiciários. Apesar de tal relação ter sido colocada aqui de modo exploratório, é preciso aprofundar as análises a respeito do alcance da rede de serviços substitutivos e da situação dos esquecidos dos manicômios judiciários. $\mathrm{O}$ baixo número de esquecidos dos manicômios judiciários de Minas Gerais - apesar de ser a quinta unidade da Federação em quantidade de pacientes em medida de segurança — pode ser explicado pela combinação de uma importante rede de serviços substitutivos de saúde mental com um programa que oferece acompanhamento integral aos pacientes em medida de segurança, com base nos princípios da Lei 10.216: o Programa PAI-PJ. Isto é, a combinação entre serviços substitutivos da Lei da Reforma Psiquiátrica e um programa da política de segurança pública, que tem prerrogativas específicas de acompanhar as medidas de segurança, parece indicar caminhos para o atendimento dos pacientes em medida de segurança na perspectiva da garantia dos direitos humanos. 
As consequências a partir da relação entre os serviços substitutivos de saúde mental e um programa intersetorial que acompanha a execução das medidas de segurança, como o PAIPJ, em Minas Gerais, e o PAILI, em Goiás, podem ser significativas para favorecer o processo de desinternação dos indivíduos em medida de segurança. A cobertura limitada desses programas em seus estados (BARROS-BRISSET, 2010; BRASIL, 2010a; SILVA, 2010), bem como a inexistência de programas como estes nas demais unidades da federação faz com que o trabalho de oferecer assistência e apoio aos indivíduos na desiternação fique por conta das famílias dos indivíduos em sofrimento mental. A inexistência de programas específicos para acompanhar as medidas de segurança e, principalmente a fase da desinternação por meio de ações articuladas entre os sistemas de justiça, as políticas de saúde mental, a política de assistência social e até mesmo programas de trabalho e emprego acaba deixando a cargo das famílias tal atribuição, o que caracteriza o familismo do tipo omissão como aquele em que as famílias atuam por ausência total da atuação do Estado. Os dados demonstrados de que os indivíduos acompanhados pelo Programa PAIP-PJ e pelo PAILI, em sua maioria, residem com suas famílias (BRASIL, 2010a; MINAS GERAIS, 2014) evidencia esse funcionamento do familismo.

Isoladamente, os dados sociodemográficos, de diagnósticos e penais pouco ou quase nada explicam sobre a existência dos indivíduos esquecidos dos manicômios judiciários brasileiros. Se não são as características sociodemográficas e de diagnósticos que particularizam tal situação, nem as características relacionadas aos tipos de crimes cometidos, é possível afirmar que parte importante da explicação do fenômeno dos esquecidos dos manicômios judiciários tem relação com o que ocorre após a declaração da cessação de periculosidade, portanto, na fase de desinternação dos pacientes. A forma como se dá a desinternação, a relação entre a administração penitenciária, a psiquiatria, a justiça, as políticas públicas e as famílias pode descortinar o universo por trás do desafiante processo de retorno à liberdade dos indivíduos em medida de segurança.

Ao destinar esforços para compreender o itinerário de desinternação dos indivíduos em medida de segurança, não se está partindo do pressuposto da eficácia das medidas de segurança em regime manicomial, nem se pressupõe que os trâmites administrativos e penitenciários da execução das medidas de segurança não resulte em violações de direitos das pessoas em sofrimento mental. Os esquecidos dos manicômios judiciários podem surgir com a ocorrência ou não desses eventos durante a extensão das medidas de segurança para tratamento psiquiátrico obrigatório. Ao analisar como ocorre a desinternação dos sujeitos em 
medida de segurança, este estudo buscou ressaltar que, mesmo que a aplicação das medidas de segurança fosse uma medida de assistência em saúde mental adequada e que não ocorressem violações de direitos durante sua execução, a fase de desinternação continuaria sendo um critério importante de ser analisado no tocante à relação entre políticas sociais, família e segurança pública no momento do retorno à liberdade dos indivíduos em sofrimento mental.

A fase da desinternação é o momento em que as medidas de segurança deixam de ser um objeto somente da segurança pública e emaranham-se com as políticas de saúde mental e de assistência social. Esse aspecto é importante, mas não apenas por isso. Para Castel (1980), a ideia de ordem asilar predominante no modelo manicomial é que ela se perpetua onde persistirem elementos capazes de sustentá-la, como é o caso do isolamento para o tratamento psiquiátrico das medidas de segurança. As medidas de segurança são a última fronteira da reforma psiquiátrica, pois guardam no seu funcionamento elementos do modelo manicomial instalado ainda no início do século XIX no mundo e entre final do século XIX e início do XX no Brasil. Segundo Castel, "a ordem asilar é sempre verdadeiramente uma ordem, isto é, um sistema, uma estrutura, uma lógica, uma dinâmica que se perpetua simplesmente por força de se repetir” (1980, p. 254). A força extraordinária da ordem asilar é que ela rompe, desenraiza, quebra, isola o sujeito para homogeneizá-lo, reconstruí-lo e reprogramá-lo em um novo perfil normatizado (CASTEL, 1980). Nesse sentido, o poder dos manicômios judiciários continua muito vivo no ordenamento social brasileiro, com um papel bastante claro de ressocializar e refamiliarizar os sujeitos com o objetivo de superar sua periculosidade.

A sustentação da ordem asilar está, sobretudo, no "lado de fora", entendido como a comunidade envolvente, o meio social e humano que suscita os problemas que a psiquiatria deve absorver e também sustenta esse campo como a ordem que será legitimada para responder aos problemas sociais postos pela saúde mental (CASTEL,1980). A esse lado de fora corresponde a organização administrativa do modelo asilar, por meio da instituição, das práticas e dos saberes que, não partindo do interior do asilo mas, pelo contrário, dando suporte do exterior do meio social, fortalecem e perpetuam o saber psiquiátrico (CASTEL, 1980). Na medida em que a reforma psiquiátrica dos anos 1970 provocou um deslocamento do saber e do poder psiquiátrico em direção à comunidade, aos serviços de meio aberto, não asilares, os elementos a darem sustentação a esse novo modelo também necessitam estar presentes.

As medidas de segurança são o meio caminho entre o modelo asilar e a reforma psiquiátrica. Em primeiro lugar, o "lado de fora" que envolve a ordem asilar pode ser também 
a ordem social e os mecanismos por meio dos quais uma sociedade liberal gestou uma instituição totalitária como aquela que irá responder aos problemas postos por um novo modo de integração dos indivíduos às normas de produtividade e controle social (CASTEL, 1980). Os manicômios nascem e se desenvolvem no Brasil paralelamente ao nascimento e crescimento dos manicômios judiciários, e ambos cumprem o papel tutelar de oferecer assistência integral ao sujeito numa perspectiva descolada da garantia dos direitos de cidadania, visto que essa noção adentra o ordenamento jurídico brasileiro somente depois dos anos 1990 (ver capítulo 4). Em segundo lugar, para Castel, "o asilo não seria tanto esse monstro singular que fascina se pudéssemos compreender melhor as relações que ele mantém com a condição social 'normal', a ordem da família, a ordem da justiça distributiva, a ordem da produtividade, etc" (1980, p. 256). É para esse complexo que o circuito familista nas políticas de assistência social e de saúde mental estrutura, ao situar a desinternação das medidas de segurança a meio caminho entre os escombros do passado e a saúde mental em meio aberto, que acena com os avanços do futuro.

A análise aqui elaborada dos esquecidos dos manicômios judiciários buscou responder a uma pergunta de duas partes: primeiro, que lugar na divisão do trabalho esse grupo social ocupa? Ao descrever as características de idade, sexo, cor da pele/raça, escolaridade e profissão, são delineados os desafios para integrar e socializar indivíduos que nunca foram integrados e nunca foram socializados antes. Nos termos de Castel (1980), uma problemática sociológica do poder exige uma análise dos grupos sociais, de suas estratégias, do lugar que ocupam na divisão do trabalho, em função da estratificação social. Segundo ele, é nesse sentido, "mais do que por uma análise formal das estruturas institucionais, que se pode esperar descobrir essas relações que ligam as estruturas psiquiátricas ao conjunto social" (CASTEL, 1980, p. 270).

Em segundo lugar, os esquecidos dos manicômios judiciários cumprem quais funções e são resultado de quais funções nessa ordem asilar? Os esquecidos estão na extremidade de uma longa cadeia de desdobramentos e trajetórias de desigualdades, vulnerabilidades, sofrimento, rejeições, fracassos e desproteções. Segundo Castel, a violência imposta aos pacientes pelos manicômios se exerce já nos outros aparelhos sociais, por isso, "em vez de permanecermos fixados na oposição entre 'dentro' e 'fora', seria preciso daqui para a frente analisar aquilo que no funcionamento concreto das relações de poder nestes 'mundos', faz deles um continuum" (1980, p. 271). A ideia do circuito familista esboçada nos dois capítulos anteriores tenta revelar como esse continuum se manifesta na inter-relação entre a segurança 
pública e as políticas de saúde mental e assistência social quando está se falando de um período transitório entre o modelo asilar e o modelo comunitário de serviços substitutivos em meio aberto, em um momento em que a política de assistência social e de saúde mental também buscam se estruturar em novas bases, com dificuldades de se desvencilhar de padrões limitados do passado. 


\section{ESTUDO DE CASO NO DISTRITO FEDERAL: A EXPRESSÃO DO FAMILISMO NA ASSISTÊNCIA PÚBLICA NA FASE DE DESINTERNAÇÃO}

Até o primeiro Código Penal da República brasileira, de 1890, era possível que os loucos que cometessem crimes fossem cuidados por suas famílias (PERES; NERY FILHO, 2002). O surgimento dos manicômios judiciários, do conceito de periculosidade e das medidas de segurança, nas décadas de 1930 e 1940, provocou uma ruptura nessa possibilidade. Embora não recebam uma pena comum pelo ato infracional cometido, os indivíduos acometidos de enfermidades mentais devem ser submetidos a acompanhamento psiquiátrico obrigatório por tempo indeterminado até que pudessem voltar a conviver em sociedade. De um lado, isso revelou o avanço do saber psiquiátrico para o tratamento de um público que até bem pouco tempo antes tinha seu comportamento descrito como resultado do castigo divino nos discursos religiosos. De outro, nas primeiras décadas do século XX, ampliou o poder de atuação do Estado perante uma problemática que até então estava circunscrita aos limites da atuação das famílias em oferecer proteção e cuidado aos seus membros.

A partir dos anos 1990 e 2000, o país experimentou um conjunto de ações para oferecer assistência às pessoas em sofrimento mental e também passou a atender às necessidades básicas dos indivíduos em situação de privações por meio da política de assistência social. Essas duas ações não alcançaram, em grande escala, as pessoas em cumprimento de medida de segurança. Isso não ocorreu tanto pelo fato de que a atenção às medidas de segurança ainda permanece como uma temática limitada aos ditames da segurança pública, como também porque as políticas de saúde mental e de assistência social não foram suficientemente ampliadas a ponto de alcançar as pessoas em medida de segurança. A fase da desinternação dos indivíduos em medida de segurança é um cenário que pode ser repleto de prenúncios dessas lacunas das políticas de saúde mental e de assistência social.

No território brasileiro, é possível que haja uma variedade de possibilidades a respeito do ciclo da desinternação de indivíduos que cumpriram medida de segurança. A cessação da periculosidade é uma exigência do Código Penal, mas o itinerário da desinternação se dá com uma teia de possibilidades para incorporar um procedimento técnico a uma dinâmica administrativa dos regimentos penais (BARROS-BRISSET, 2010). O tratamento psiquiátrico é obrigatório por tempo indeterminado até o momento em que o juiz de execução penal autoriza a desinternação da pessoa. No Distrito Federal, segundo uma das entrevistadas para esta tese, que compõe a equipe da Vara de Execuções Penais (VEP) e é responsável pelo 
acompanhamento das medidas de segurança, "quando há parecer favorável de todas as partes [Ministério Público, defesa e juiz] para a desinternação condicional, a Seção Psicossocial contata os familiares, marca a data da desinternação e avisa a Ala de Tratamento Psiquiátrico para preparar o sentenciado para a desinternação...” (ENTREVISTADA 2). É um rito no qual o trabalho com as famílias é regra.

O serviço de assessoramento psicossocial ao juízo da execução penal no Distrito Federal teve início em 1984 (DISTRITO FEDERAL, 2014). Em 17 de agosto de 1987, houve a publicação da Portaria 3, que consolidou o espaço profissional do psicólogo e do assistente social na Vara de Execuções do DF. A Seção Psicossocial tem o objetivo de assessorar o juiz da VEP nas decisões relativas à execução das penas, com ênfase nos aspectos psicossociais, além de acompanhar e fiscalizar o cumprimento das decisões judiciais relativas às penas privativas de liberdade e medidas de segurança e articular com outros órgãos para promover o retorno do sentenciado ao convívio social (DISTRITO FEDERAL, 2014). A Seção atua em três frentes: estudo psicossocial relativo aos sentenciados condenados a penas privativas de liberdade, avaliação da concessão de trabalho externo aos beneficiados com regime semiaberto e acompanhamento e fiscalização das medidas de segurança, sendo seus usuários os sentenciados submetidos a penas privativas de liberdade e medidas de segurança nas modalidades de internação e tratamento ambulatorial (DISTRITO FEDERAL, 2014).

A passagem da fase da tutela manicomial para a tutela familiar é autorizada por um conjunto de procedimentos administrativos para os quais a família e a administração penal estão colimadas numa única esteira de ações. A família que provê bem-estar ao indivíduo em desinternação passa a ser vista como pré-requisito fundamental para esse retorno à liberdade. Em outras palavras, a família e a administração penal, por meio da atuação da Seção Psicossocial da VEP-DF, têm papéis distintos, mas complementares na teia de proteção costurada para o processo de desinternação. É essa teia de relações que este capítulo aborda, depois de um estudo de caso conduzido por quatro meses na VEP do Distrito Federal.

\subsection{Características dos indivíduos em desinternação na ATP-DF}

Com o objetivo de analisar o itinerário de desinternação dos indivíduos em medida de segurança, foram examinados 40 processos de indivíduos em medida de segurança da Ala de Tratamento Psiquiátrico (ATP) do Distrito Federal de 2013. Foram analisados 23 processos de medidas de segurança extintas e 17 processos de medidas de segurança em processo de de 
desinternação. Os 40 processos representavam o universo de processos em fase de desinternação naquele ano na ATP-DF. A seguir, são apresentadas características do grupo de 40 processos de indivíduos em desinternação e daqueles com a medida extinta em 2013 no Distrito Federal. A Tabela 14 mostra a faixa etária dos indivíduos em medida de segurança:

\section{Tabela 14 Faixa etária das MS em desinternação e extintas da} ATP-DF

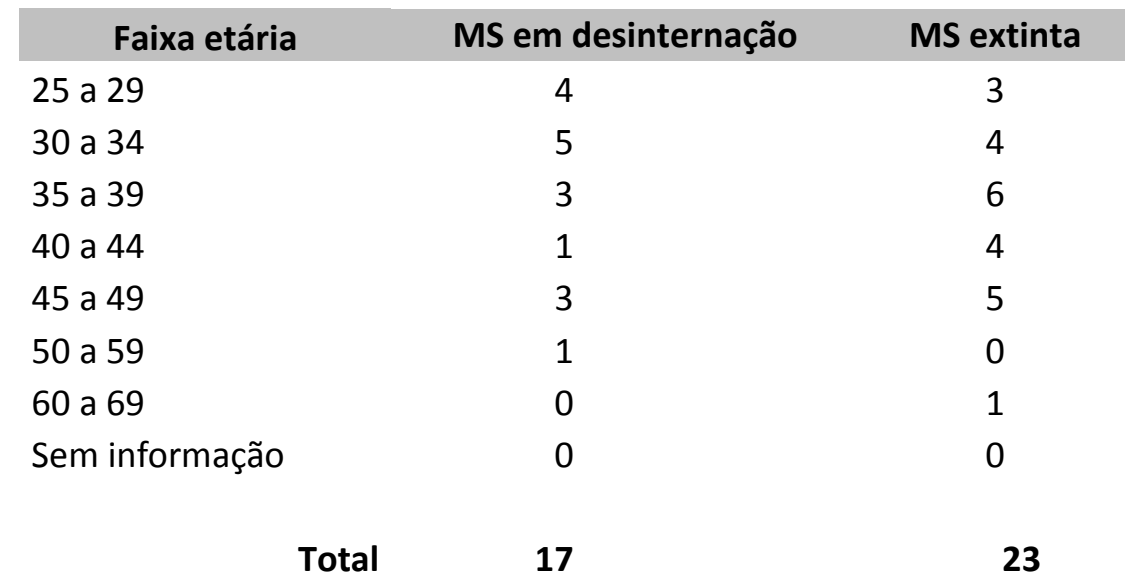

Fonte: Tabela elaborada pelo próprio autor da tese

Há uma concentração de indivíduos com a medida extinta na faixa entre 35 e 49 anos em 2013. Dos 23 indivíduos com medida de segurança extinta nesse ano, 15 estavam nessa faixa etária. Já entre aqueles em processo de desinternação, a concentração estava entre as faixas de 30 a 39 anos, com 8 indivíduos. Entre as medidas extintas, havia um único indivíduo entre 60 e 69 anos e, entre os indivíduos em medida de segurança, o indivíduo de maior idade se localizava na faixa entre 50 e 59 anos.

Tabela 15 Situação conjugal das MS em desinternação e extintas da ATP-DF

\begin{tabular}{lcc}
\multicolumn{1}{c}{ Situação conjugal } & MS em desinternação & MS extinta \\
Casado & 0 & 3 \\
Divorciado & 0 & 0 \\
Viúvo & 0 & 0 \\
Solteiro & 14 & 17 \\
Amasiado & 1 & 2 \\
Sem informação & 2 & 1 \\
& \multicolumn{2}{c}{ Total } \\
Fonte: Tabela elaborada pelo próprio autor da tese
\end{tabular}


Em um cenário bastante próximo do encontrado no estudo censitário publicado em 2012, há uma concentração de solteiros entre os indivíduos em medida de segurança: 17 daqueles que tiveram a medida de segurança extinta e 14 daqueles em fase de desinternação no Distrito Federal eram solteiros em 2013. Entre os que tiveram a medida extinta, 3 eram casados, e um único indivíduo em desinternação era amasiado.

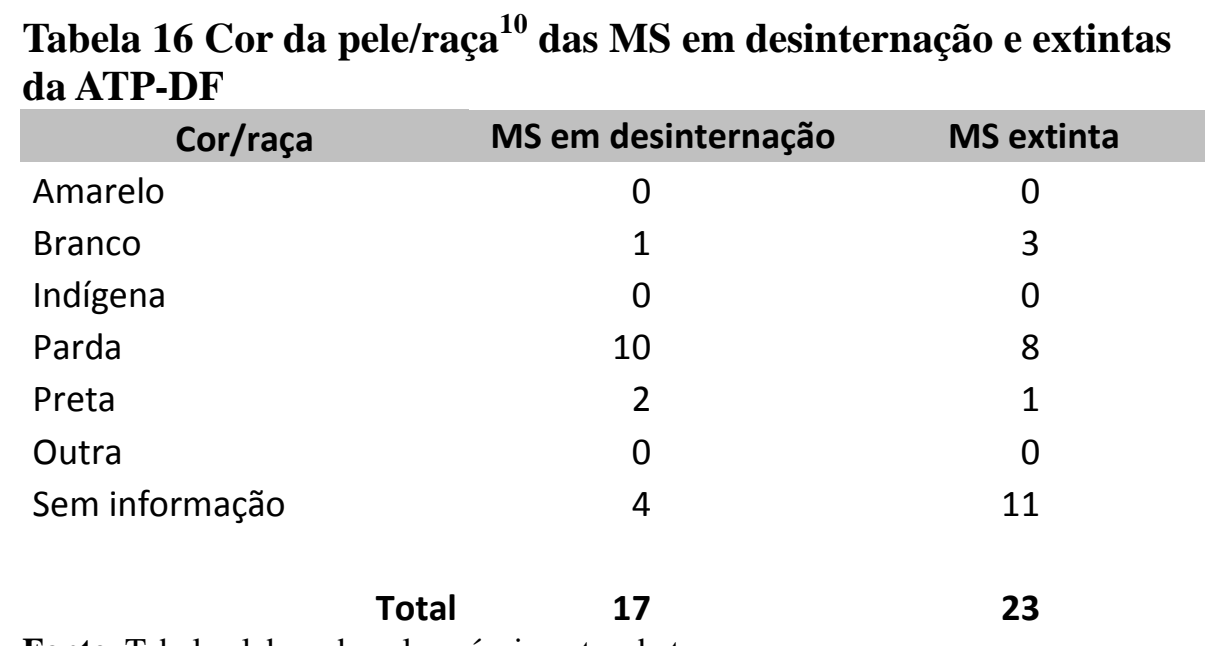

Fonte: Tabela elaborada pelo próprio autor da tese

Havia um total de 12 de pretos e pardos entre os indivíduos em desinternação em 2013 no Distrito Federal e de 9 pretos e pardos entre aqueles com medida de segurança extinta. Não havia informações sobre cor da pele ou raça de grande parte dos indivíduos com medida de segurança extinta, de 11 indivíduos. Havia um único indivíduo branco nas medidas de segurança em desinternação e 3 de indivíduos brancos entre as medidas de segurança extintas.

Tabela 17 Escolaridade das MS em desinternação e extintas da ATP-DF

\begin{tabular}{|c|c|c|}
\hline Escolaridade & MS em desinternação & MS extinta \\
\hline Analfabeto & 4 & 2 \\
\hline Fundamental incompleto & 9 & 11 \\
\hline Fundamental & 1 & 0 \\
\hline Médio & 3 & 6 \\
\hline Superior & 0 & 0 \\
\hline Pós-graduação & 0 & 0 \\
\hline Sem informação & 0 & 4 \\
\hline Total & 17 & 23 \\
\hline \multicolumn{3}{|c|}{ Fonte: Tabela elaborada pelo próprio autor da tese } \\
\hline
\end{tabular}


A maioria dos indivíduos em medida de segurança em desinternação, 13 indivíduos, era de analfabetos ou tinha apenas o ensino fundamental incompleto. Entre os indivíduos com medida de segurança extinta, esse número caía para 13 dos 23 processos analisados. Não havia, entre os indivíduos em desinternação e entre aqueles que tiveram a medida extinta em 2013, ninguém com ensino superior. Havia 6 indivíduos com ensino médio completo entre os indivíduos com medida de segurança extinta e 3 indivíduos com ensino médio entre aqueles em fase de desinternação.

\section{Tabela 18 Profissão das MS em desinternação e das MS extintas da ATP-DF}

\begin{tabular}{lcc}
\multicolumn{1}{c}{ Profissão } & MS em desinternação & MS extinta \\
Forças Armadas, militares etc & 0 & 2 \\
Ciências e artes & 0 & 2 \\
Técnico de nível médio & 1 & 0 \\
Serviços administrativos & 0 & 0 \\
Comércio em lojas e mercados & 1 & 1 \\
Agropecuários florestais e pesca & 1 & 2 \\
Serviços industriais & 0 & 0 \\
Reparação e manutenção & 4 & 3 \\
Profissão não listada & 0 & 1 \\
Aposentado & 1 & 0 \\
Sem profissão & 7 & 8 \\
Autônomo & 0 & 0 \\
Sem informação & 2 & 4 \\
& & $\mathbf{2 3}$
\end{tabular}

Assim como no estudo censitário nacional, a maioria dos indivíduos em desinternação e com medida extinta do Distrito Federal em 2013 não tinha profissão. Entre os indivíduos em desinternação, 7 não tinham profissão e, entre os indivíduos que tiveram a medida extinta, 8 não tinham profissão. As profissões de maior prevalência nos dois grupos foram as de manutenção e reparação: 3 e 4 dos indivíduos com medida extinta e em desinternação, respectivamente.

O conjunto dessas características sociodemográficas elucida os desafios para a desinternação das pessoas em medida de segurança. As características acumulam camadas de vulnerabilidades sociais que potencializam a situação de abandono dos indivíduos em restrição de liberdade nos ECTPs. Se a restrição de liberdade não é capaz de superar as condições de vulnerabilidade em que os indivíduos se encontram, o prolongamento da 
extensão das medidas as aprofunda. A fala abaixo, de uma das entrevistadas que trabalha na VEP-DF e é responsável pelo acompanhamento das medidas de segurança, demarca essa característica:

É um problema em cadeia, em ciclo: a falta de formação profissional e educacional dificulta o acesso ao trabalho, que, por sua vez, diminui as possibilidades de aumento de renda, e a pobreza dificulta o acesso aos tratamentos (medicações e transporte). Enfim, a vulnerabilidade social é a principal passagem de entrada para o sistema prisional do paciente psiquiátrico (ENTREVISTADA 3).

Tal cenário aponta que, no cumprimento das medidas de segurança, deve haver uma maior articulação com as políticas de proteção social, tais como de assistência social, educação, trabalho e emprego, que sejam capazes de oferecer condições para minorar o ciclo de pobreza dos indivíduos com doenças e transtornos mentais. Trabalho, educação e renda são demarcadores de inserção social. Quanto menos acesso a essas três dimensões os pacientes com transtornos mentais tiverem, menos possibilidades de experimentar autonomia eles terão. A experiência da doença mental desafia os arranjos tradicionais de proteção social que as políticas públicas construíram tardiamente, nos últimos doze anos, no Brasil.

Isto é, a proteção social tem uma relação umbilical com o mundo do trabalho e com as famílias no que diz respeito à provisão social quando as políticas sociais são insuficientes ou inexistentes (DI GIOVANNI, 1998; PEREIRA, 2006a). No caso de pessoas com doenças e transtornos mentais que cometem crimes, tais tensionamentos vêm à tona. Em primeiro lugar, a proteção social, tanto social quanto jurídica, oferecida pelo mundo do trabalho (CASTEL, 1995) é inexistente para grande parcela da população com doenças e transtornos mentais. Em segundo lugar, a ausência da família, como instância que primeira e tradicionalmente oferece apoio e provisão de bem-estar, pode ter impactos significativos para proteção social dos indivíduos em sofrimento mental.

A relação entre loucos, sociedade, família e políticas públicas é entrecortada pelas regras que organizam a sociedade, tendo o trabalho como um dos aspectos centrais das sociedades contemporâneas após a Revolução Industrial. Há uma diferença marcante sobre o modo como o uso do trabalho como tratamento dos loucos, aos poucos, foi deslizando desde o século XVIII tendo o trabalho como castigo moral e como terapia para então chegar ao início do século XXI onde o trabalho passou a ser redescrito como um direito dos indivíduos em sofrimento mental.

Em primeiro lugar, o uso do trabalho como tratamento moral dos loucos foi 
determinado pelo modo como arquitetura do asilamento foi construída na Europa pelo modelo manicomial, principalmente na França e Inglaterra e qual modelo se espraiou para os demais países (CASTEL, 1979). Isto é, para Castel, a resposta dada à problemática da loucura foi antes derivada da resposta dada à necessidade de organizar os pobres despossuídos que, da transição do regime feudal para o industrial, estavam desamparados nas cidades e era preciso oferecer tanto organização quanto proteção a esses públicos (CASTEL, 1995). Para Castel, o denominado campo "social-assistencial” (1995:115) é o campo que tinha por função principal a proteção e a integração dos indivíduos por meio de instituições especializadas, como os hospitais, asilos, abrigos, workhouses ou casas de trabalho (CASTEL, 1995).

Selecionados a partir dos critérios do pertencimento comunitário e da inaptidão ao trabalho, o objetivo do modelo social-assistencial era evitar a não integração dos grupos sociais à sociedade (CASTEL, 1995). Na perspectiva de Castel seria evitar "a ruptura em relação à ordem de produção e o isolamento em relação à ordem sócio-asilar" (1994:3). Desse modo, os hospitais gerais, os asilos, as workhouses, as colônias agrícolas, as prisões, entre outras instituições correicionais-disciplinares foram criadas tendo por base a lógica socialassistencial com o objetivo de integrar os indivíduos à lógica produtiva. A principal consequência dessa situação foi, de um lado, a demarcação do trabalho como o lugar definitivo que inscreve os indivíduos na situação de proteção diante dos acasos e dinâmica imposta pela sociedade industrial, mas que, por outro lado, demarca bem as diferenças entre aqueles que estão inábeis ao trabalho e, portanto, serão a eles destinados as proteções assistenciais.

No interior dos hospitais gerais e dos manicômios, o trabalho assume a feição repressiva e de castigo, sem necessariamente almejar alcançar a lógica produtiva. A terapia moral para o trabalho servia para forjar as técnicas e práticas disciplinares necessárias ao regime fabril e, ao mesmo tempo, funcionava como controle dos corpos no interior das instituições manicomiais (CASTEL, 1979). Na Europa do século XVIII, definitivamente, o trabalho passa a compor um cenário de assistência à loucura como tratamento moral da qual se desvincularia apenas ao longo do século XX. No caso brasileiro, até metade do século XIX, os loucos eram tratados junto a todos os grupos de marginalizados e, antes de ser uma questão necessária de respostas da assistência em saúde, a loucura carregava os traços da periculosidade para o necessário tratamento enquanto questão de polícia e de segurança pública (AMARANTE, 1994). A presença do trabalho como terapia moral e como mecanismo de gerir a própria sustentação dos manicômios e hospitais colônias esteve presente 
no Brasil até os anos 1980 (MARTINS, 2009). A partir deste momento, o trabalho para os loucos assume nova conotação mais próxima a descrição de necessidades sociais ou de exercício do direito ao trabalho.

Depois dos anos 1990, iniciativas de cooperativas sociais passam a ser um modelo possível de inserção dos indivíduos em sofrimento mental no mundo do trabalho (MARTINS, 2009). Buscando estabelecer alternativas sobre o processo de inserção dos indivíduos com transtorno mental no mundo do trabalho, para geração de autonomia e renda, as cooperativas passaram a ser incentivadas por meio da Lei 9.867, de 1999 (BRASIL, 1999). Tais construções têm sido fundamentais para construir possibilidades de inserção ao mundo do trabalho, mas garantindo condições para proteger as especificidades dos indivíduos em sofrimento mental na sua relação com o trabalho. A passagem do isolamento durante a medida de segurança com tratamento psiquiátrico obrigatório para a liberdade pode ter na experiência das cooperativas sociais uma rede imprescindível. Muito embora, a intervenção da política de assistência social deve compor o complexo necessário a essa passagem, como tem sido o objeto recortado na análise desta tese.

A Tabela 19 a seguir demonstra os diagnósticos dos indivíduos em medidas de segurança em desinternação e extintas no DF no ano de 2013.

Tabela 19 Diagnósticos das MS em desinternação e das MS extintas da ATP-DF

$\begin{array}{lcc}\text { Diagnóstico } & \begin{array}{c}\text { MS em } \\ \text { desinternação }\end{array} & \begin{array}{c}\text { MS extinta } \\ \text { Retardo mental }\end{array} \\ \text { Epilepsia } & 3 & 4 \\ \text { Esquizofrenia } & 8 & 0 \\ \text { Transtorno de personalidade } & 2 & 9 \\ \text { Transtornos da preferência sexual } & 0 & 3 \\ \text { Transtorno afetivo uni ou bipolar } & 0 & 0 \\ \text { Transtornos mentais devido ao uso de álcool e outras drogas } & 4 & 0 \\ \text { Transtornos mentais orgânicos } & 0 & 6 \\ \text { Outros } & 0 & 1 \\ \text { Sem informação } & 0 & 0 \\ & & 0\end{array}$

Semelhantemente ao cenário nacional das medidas de segurança (DINIZ, 2012), os principais diagnósticos são de esquizofrenia, tanto no grupo das medidas de segurança extintas, com 9 dos casos, quanto no das medidas de segurança em processo de desinternação, 
com 8 casos. Já em um quadro bastante particular quando comparado ao cenário nacional, no Distrito Federal, a segunda maior concentração de diagnósticos é de transtornos mentais devido ao uso de álcool e outras drogas, enquanto na maioria das demais unidades o segundo diagnóstico mais recorrente era o de retardo mental. Assim como no censo nacional (DINIZ, 2012), entre a população em processo de desinternação, esses transtornos também foram o segundo tipo mais prevalente, com 4 casos. Entre os indivíduos com a medida de segurança extinta, 6 tinham esse diagnóstico.

$\mathrm{Na}$ sequência, entre os indivíduos com a medida de segurança extinta, havia 4 com retardo mental, percentual que subia para 3 entre aqueles em desinternação. Esse diagnóstico de retardo mental traz desafios adicionais para a execução das medidas de segurança: não se trata de uma doença passível de cura ou controle, mas de um estado para o qual o acompanhamento especializado, tanto terapêutico quanto pedagógico, não é oferecido em um ECTP.

Como salienta uma das entrevistadas que é servidora da VEP-DF, os casos dos indivíduos com transtornos mentais devido ao uso de álcool e outras drogas são ainda mais desafiantes para o processo de desinternação:

a desinternação dos indivíduos em medidas de segurança é relativamente fácil de ser cumprida pelos pacientes que possuem apoio familiar e que conseguem uma boa adesão ao serviço de saúde para o qual foi encaminhado, pois os familiares aprendem a administrar as crises. Entretanto, os casos de desinternação condicional de pacientes dependentes químicos demonstram que a adesão ao tratamento é mínima e o retorno do paciente ao sistema prisional é muito frequente, transformando o tempo de internação de 1 ano em 5, 6 anos de vínculo com a Justiça (ENTREVISTADA 2).

De acordo com um dos entrevistados, o trabalho desenvolvido pela Seção Psicossocial da VEP-DF com a rede de saúde é um dos pré-requisitos para dar continuidade ao processo de desinternação dos indivíduos em medida de segurança. Desse modo,

quando encaminhamos pacientes para um dos serviços, normalmente fazemos estudo de caso junto às equipes antes do acolhimento, mas varia conforme a disponibilidade da equipe e dos serviços. Sempre buscamos o serviço de saúde mais próximo da região onde o paciente reside, até para facilitar a adesão ao tratamento. Não existe serviço residencial terapêutico no DF, e a Casa de Passagem tem uma limitação de vagas e não tem característica de residência terapêutica (ENTREVISTADO 4).

Segundo o mesmo entrevistado, "para que a desinternação ocorra, é necessário que o paciente seja referenciado em algum serviço, mesmo que não seja próximo de sua residência”. 
Essa vinculação, entre a política de segurança pública e a rede de saúde mental, é fundamental para a continuidade do acompanhamento e tratamento para que os pacientes alcancem condições de superar o quadro de manifestação dos sintomas das doenças e dos transtornos. Além disso, estabelece uma cadeia de relações para fora do ambiente manicomial que pode ser crucial para garantir a segurança de convívio familiar e comunitário dos indivíduos. A fase da desinternação é o momento decisivo para que a inserção social e comunitária se dê de modo a promover o desenvolvimento dos indivíduos que cumpriram medida de segurança.

Essa ligação entre o sistema penal e as redes comunitárias de serviços de saúde se constitui numa trama de relações para as quais se evidenciam os limites do modelo manicomial como capaz de criar contextos de autonomia dos sujeitos que cumprem medida de segurança. Todos os entrevistados relataram os constantes retornos das famílias em busca de orientação e apoio da equipe da Seção Psicossocial da VEP quando as políticas de saúde mental e de assistência social são insuficientes na oferta desses serviços. De acordo com uma das entrevistadas,

as famílias recorrem à Seção Psicossocial para resolução de todos os entraves encontrados durante o período de desinternação. É muito difícil fazê-los criar o hábito de se dirigir aos recursos comunitários e socioassistenciais e não à Justiça. Um dos maiores entraves no trabalho com as famílias é a dependência que eles criam da Justiça (ENTREVISTADA 2).

O circuito familista, salientado anteriormente no arcabouço das políticas de assistência social e de saúde mental, fica evidente nesse trecho. Não só os serviços de saúde mental e socioassistenciais devem ser referenciados aos pacientes em medida de segurança para promover a inserção social e comunitária dos indivíduos em medida de segurança, mas há uma profunda dependência sedimentada entre as famílias e o sistema de Justiça em um ciclo que se retroalimenta. A passagem do regime assistencial oferecido pelo manicômio judicial para um regime de inserção comunitária e familiar esbarra nos limites dos serviços substitutivos. Mas também, principalmente, na dependência institucional que os indivíduos em medida de segurança adquirem por terem se submetido tanto tempo aos regramentos manicomiais, que oferecem respostas automatizadas aos pacientes e suas famílias.

Essa relação de dependência das famílias com a Seção Psicossocial é o aspecto para que Castel (1979) chama a atenção quando fala da dependência entre "o dentro" e "o fora" no modelo manicomial, como salientado no capítulo anterior. Para Castel, grande parte do regime de violência imposta aos pacientes pelos manicômios não se dá meramente pelo processo de exclusão do meio social. Ocorre também porque a lógica manicomial oferece sentido aos 
sujeitos envolvidos e cumpre atribuições específicas do processo existencial dos pacientes e suas famílias, tornando custoso o rompimento delas com o regime custodial. Segundo Castel, por isso, seria preciso superar a fixação de análises sobre a oposição entre 'dentro' e 'fora', para conseguir alcançar o enquadramento daquilo que no funcionamento concreto das relações de poder nestes 'mundos', faz deles um continuum (CASTEL, 1980). É desse continuum entre os mundos manicomiais e de inserção comunitária que o circuito familista ganha força para estruturar a relação entre as demandas por proteção social dos indivíduos em sofrimento mental, as políticas sociais e as famílias.

O conceito de periculosidade, que determina a apartação do meio social dos indivíduos em medida de segurança, é sem dúvida uma barreira importante a ser superada. Há uma série de direitos fundamentais que são negados em decorrência do paradigma da periculosidade. Mas a periculosidade é mais do que isso. É o que permite que, para além do crime cometido, o indivíduo em sofrimento mental seja alguém sobre o qual a teia de vigilância deve ser contínua, por meio das instituições disciplinares, correcionais e familiares (FOUCAULT, 1977). A relação da família com o sujeito em medida de segurança é permeada pelas ameaças — concretas ou não - que o temor da periculosidade causa na relação entre grupo familiar e paciente e entre este último e as redes de vizinhança, comunidade, etc. A periculosidade cola ao sujeito louco que comete crimes uma espécie de pânico antecipatório e coletivo como se, a qualquer momento, ele pudesse praticar novo ilícito. Talvez estejam aí também as interpretações de por que há uma relação de dependência entre os arranjos familiares e o sistema de Justiça. Certamente, esse é um dos principais desafios para destravar essa temática para além da esfera da segurança pública e aproximá-la da esfera da assistência pública para a garantia de direitos básicos, como no caso da assistência social e da política de saúde mental em meio aberto, ensejada pela Lei 10.216.

A Tabela 20 demonstra os crimes cometidos pelos indivíduos em processo de desinternação em 2013 no Distrito Federal: 
Tabela 20 Crimes cometidos das MS em desinternação e das MS Extintas da ATP-DF

\begin{tabular}{lcr}
\multicolumn{1}{c}{ Crime cometido } & MS em desinternação & MS ex \\
Contravenções penais & 0 & 1 \\
Crimes contra a dignidade sexual & 3 & 4 \\
Crimes contra a fé pública & 0 & 1 \\
Crimes contra a vida & 4 & 5 \\
Crimes contra o patrimônio & 10 & 9 \\
Crimes da lei anti-drogas & 0 & 1 \\
Lesão corporal & 0 & 2 \\
Total & $\mathbf{1 7}$ & $\mathbf{2 3}$
\end{tabular}

Fonte: Tabela elaborada pelo próprio autor da tese

Os principais crimes cometidos pela população em desinternação e com medida de segurança extinta no Distrito Federal em 2013 foram os crimes contra o patrimônio. Entre as pessoas com medida de segurança extinta, 9 cometeram esse tipo de crime e, entre aqueles em desinternação, 10. Esse cenário também apareceu no estudo censitário publicado em 2012, quando a ATP do Distrito Federal foi o único ECTP em que os crimes contra o patrimônio foram os principais atos infracionais cometidos pela população em medida de segurança, superando os crimes contra a vida. Os crimes contra a vida foram praticados por 5 das pessoas com medida de segurança extinta e por 4 daquelas em desinternação em 2013.

Tabela 21 Tempo de internação das MS em desinternação e das MS extintas da ATP-DF

$\begin{array}{lcc}\text { Tempo da internação } & \text { MS em desinternação } & \text { MS extinta } \\ \text { Menos de um ano } & 0 & 0 \\ 1 \text { a } 5 \text { anos } & 7 & 15 \\ \text { 6 a 10 anos } & 7 & 5 \\ 11 \text { a } 15 \text { anos } & 3 & 0 \\ \text { Sem informação } & 0 & 3 \\ \text { Total } & \mathbf{1 7} & \mathbf{2 3}\end{array}$

Fonte: Tabela elaborada pelo próprio autor da tese

Dos indivíduos que tiveram a medida de segurança extinta em 2013 no DF, 15 ficaram internados entre 1 e 5 anos e 5 ficaram internados entre 6 e 10 anos. Entre os indivíduos em desinternação no mesmo ano no Distrito Federal, 7 estavam internados havia entre 1 e 5 anos e outros 7 , entre 6 e 10 anos. 
Tabela 22 Recidiva das MS em desinternação e das MS extintas da ATP-DF

\begin{tabular}{|c|c|c|}
\hline Recidiva & MS em desinternação & MS extinta \\
\hline Sim & 7 & 9 \\
\hline Não & 10 & 8 \\
\hline Sem informação & 0 & 6 \\
\hline Tc & 17 & 23 \\
\hline
\end{tabular}

Fonte: Tabela elaborada pelo próprio autor da tese

Entre os indivíduos com as medidas de segurança extintas em 2013 no Distrito Federal, a concentração de recidivantes estava em 9 casos dos 23 processos analisados. Entre os indivíduos em desinternação, havia 7 casos de recidiva. No censo nacional publicado em 2012 (DINIZ, 2012), revelou-se que o Distrito Federal possuía uma taxa de recidiva maior que a dos demais ECTPs do país. Enquanto, no Brasil, 24\% dos indivíduos em medida de segurança tinham cometido um crime anterior ao que levou à atual medida de segurança, no Distrito Federal, a taxa de recidiva estava em 34\%, em 2011 (DINIZ, 2012). A recidiva maior no Distrito Federal pode ser explicada, principalmente pela natureza dos atos infracionais aqui cometidos, que se concentram nos crimes contra o patrimônio. É comum um número alto de furtos, roubos, tentativas de furto e tentativas de roubo fazer parte do itinerário penal dos indivíduos em medida de segurança no Distrito Federal.

Tabela 23 Crimes contra a família das MS em desinternação
e das MS extintas da ATP-DF
$\begin{array}{lcc}\text { Crime contra a família } & \text { MS em desinternação } & \text { MS extinta } \\ \text { Sim } & 0 & 6 \\ \text { Não } & 17 & 16 \\ \text { Sem informação } & 0 & 1\end{array}$

Total $\quad 17$

Fonte: Tabela elaborada pelo próprio autor da tese

Diferente do cenário nacional, a população da ATP-DF tinha, em 2011, uma concentração menor de crimes contra a família praticados pelos indivíduos em medida de segurança, 10\% da população, número que, nos demais ECTPs, era de 27\% (DINIZ, 2012). Na população analisada na fase de desinternação no Distrito Federal em 2013, a situação não era diferente. No caso das medidas extintas, em 6 casos os crimes cometidos pelos indivíduos tinham um membro da família como vítima. Nas medidas de segurança em desinternação, não 
houve caso de crime cuja vítima fosse membro da família. Essa característica de menor quantidade de crimes cometidos contra a família no Distrito Federal pode ser explicada pela maior ocorrência de crimes contra o patrimônio, o que reduz automaticamente a quantidade de crimes contra a vida. Entretanto, a pouca ocorrência de crimes entre aqueles os processos em desinternação referentes ao ano de 2013 no Distrito Federal não é o suficiente para eliminar os desafios em contar com as famílias para receber os indivíduos em desinternação condicional, como demonstra o seguinte trecho de uma das entrevistadas "o que é prérequisito para a desinternação é que o paciente tenha referência familiar ou local adequado para abrigamento. Este é o maior entrave na liberação: eles não terem referência familiar" (ENTREVISTADA 5).

\subsection{Extensão dos tempos de internação e itinerário da desinternação: o familismo nos trâmites processuais}

No estudo censitário publicado em 2012, foi mostrado que ao menos $17 \%$ (14) dos indivíduos em medidas se segurança do DF já não deveriam estar internados por já cumprirem os critérios penais e psiquiátricos para a desinternação (DINIZ, 2012). Comparada ao cenário brasileiro, a realidade do Distrito Federal têm melhores resultados, possuindo menos indivíduos em internação indevida por já cumprirem os critérios para a liberdade: em todo o Brasil, somava-se $25 \%$ da população em medida de segurança nesta situação e em alguns casos, como o HCTP Franco da Rocha II, em São Paulo, o total chegava a 85\% da população em medida de segurança em internação indevida, no HCTP Heitor Carrilho, no Rio de Janeiro, chegava a $63 \%$ e no HCTP Salvador, Bahia, com $48 \%$ das pessoas em medidas de segurança em custódia indevida.

Essa situação no Distrito Federal pode ter vários fatores explicativos. Mas, um deles chamou a atenção durante a análise dos processos das medidas de segurança em desinternação no ano de 2013 na VEP do Distrito Federal. É comum o trabalho da Seção Psicossocial da VEP iniciar a preparação da desinternação antes mesmo de o juiz determinar a desinternação condicional dos indivíduos em medidas de segurança. É comum o juiz aguardar a preparação da Seção Psicossocial para a desinternação condicional dos indivíduos em medidas de segurança, para só depois determinar a sentença de desinternação. Isto pode ter impactos sobre uma quantidade menor de indivíduos em situações de internação indevida na ATP-DF, o que não deixa de eliminar os desafios encontrados para a desinternação.

Perguntada sobre quando a Seção Psicossocial da VEP-DF começa a atuar para 
facilitar a desinternação das pessoas que cumpriram medida de segurança, uma das servidoras ofereceu a seguinte resposta:

\begin{abstract}
Quem sugere a desinternação do paciente é sempre a Seção Psicossocial, baseada no acompanhamento do caso e na estabilidade do quadro mental do paciente. Normalmente, discutimos as indicações de desinternação com a equipe da ATP e começamos a preparar os familiares para receber o interno. Tanto a equipe da ATP quanto a da VEP realizam procedimentos para viabilizar a desinternação. Quando fazemos a sugestão de desinternação, o juiz sempre vai solicitar um exame de Instituto Médico Legal [perícia psiquiátrica] que vai indicar se o paciente está apto a realizar o tratamento de forma ambulatorial [...]. Por esse motivo, o tempo entre a "cessação de periculosidade" e a desinternação é rápido, basta as partes se manifestarem e o paciente ter apoio familiar. A desinternação só demora quando não há referência familiar (ENTREVISTADA 1).
\end{abstract}

Isso explica o fato de que, para os 17 indivíduos em medida de segurança em desinternação em 2013 no Distrito Federal, a média de tempo entre a cessação da periculosidade e a sentença de desinternação foi de três meses, enquanto que no Brasil essa média era de 5 meses. Além disso, houve seis casos em que a sentença ocorreu no mesmo mês da declaração da cessação da periculosidade. Isto é, do procedimento técnico psiquiátrico que subsidia a decisão da desinternação condicional à efetiva desinternação autorizada pelo juiz no pronunciamento da sentença, passaram-se em média três meses. Essa média, no caso dos indivíduos que tiveram a medida de segurança extinta, foi de quatro meses.

Após a publicação da sentença de desinternação é que ocorre o retorno à liberdade dos indivíduos em medida de segurança. Dos 17 indivíduos em medida de segurança de desinternação em 2013 no Distrito Federal, oito foram desinternados no mesmo mês de publicação da sentença; para três deles, a desinternação ocorreu dois meses depois e, para outros três, 11 meses após a publicação da sentença. Proferida a sentença de desinternação, o retorno à liberdade, como afirmou a servidora da Seção Psicossocial da VEP-DF, "só demora quando não há referência familiar". Dos 23 indivíduos que tiveram a medida de segurança extinta em 2013 no Distrito Federal, oito foram desinternados no mesmo mês da publicação da sentença e, em três casos, a desinternação se deu dois meses depois. Em um único caso, o indivíduo foi desinternado um mês depois da publicação da sentença. Em 11 casos, essa informação não estava disponível nos processos analisados.

Mais importante do que destacar a maior celeridade no processo de desinternação no Distrito Federal é a alteração que ocorre, nesta unidade da federação, da ordem nos trâmites processuais para a desinternação. Em todo o país, é comum primeiro haver a realização do 
exame de cessação de periculosidade. Depois de atestada a cessação da periculosidade, há a publicação da sentença de desinternação pelo juiz da Vara de Execuções. Após a publicação da sentença de desinternação é que se iniciam os trabalhos junto às famílias e junto à rede socioassistencial e de serviços substitutivos de saúde mental para favorecer o retorno à liberdade condicional dos indivíduos em medida de segurança. O trabalho da Seção Psicossocial da VEP pode provocar até mesmo a realização do exame de cessação de periculosidade, como demonstra o trecho acima de uma das entrevistadas. Pois, segundo ela, "Quando fazemos a sugestão de desinternação, o juiz sempre vai solicitar um exame de Instituto Médico Legal [perícia psiquiátrica]". Isto significa que os desafios para a preparação de apoio e de assistência — seja dos arranjos familiares, seja do conjunto das políticas sociais disponíveis -, para receber os indivíduos para cumprir a desinternação da medida de segurança provocou a alteração até mesmo da ordem nos trâmites processuais. Sendo assim, não é correto afirmar que a maior celeridade entre a sentença de desinternação e a desinternação efetivamente se iniciar ocorre por que não há entraves para a desinternação ou a ausência de contatos familiares não é um desafio no Distrito Federal. Pelo contrário. Foi exatamente o conjunto de desafios encontrado pela equipe da Seção Psicossocial da VEP para promover a desinternação, sobretudo, no que diz respeito à "referência familiar" que fez com que esse trabalho de preparação iniciasse cada vez mais cedo, alterando até mesmo o rito processual de cumprimento das medidas de segurança.

\subsection{Moradia, proteção social e vínculo com a Justiça: as barreiras para a desinternação}

O estudo censitário realizado em 2011 demonstrou, de forma exploratória, que há uma relação entre a continuidade da internação e o apoio sociofamiliar. Essa relação já tinha sido apontada por outros estudos em unidades isoladas, como o HCTP Heitor Carrilho (MECLER, 2010). Nos casos dos indivíduos com medida de segurança extinta e com sentença de desinternação, foram investigadas as razões da não desinternação no estudo censitário. Entre os 194 indivíduos no país com sentença de desinternação que permaneciam internados, 67\% (130) não tinham contatos familiares ou local de moradia. Para 51\% (29) das medidas extintas encontradas nos ECTPs, a não desinternação ocorreu pelos mesmos motivos. Nesse sentido, uma das principais barreiras para a desinternação é a inexistência de local de moradia dos indivíduos. Na Tabela 24, há um demonstrativo dos locais de moradia dos 40 processos de desinternação do DF analisados: 
Tabela 24 Local de moradia durante a desinternação das MS em desinternação e das MS extintas da ATP-DF

$\begin{array}{lcc}\text { Tempo da internação } & \text { MS em desinternação } & \text { MS extinta } \\ \text { Família } & 13 & 20 \\ \text { Serviço Residencial Terapêutico } & 0 & 0 \\ \text { Casa de passagem } & 1 & 0 \\ \text { Comunidade terapêutica } & 3 & 2 \\ \text { Sozinho } & 0 & 0 \\ \text { Sem informação } & 0 & 1 \\ \text { Total } & \mathbf{1 7} & \mathbf{2 3}\end{array}$

Fonte: Tabela elaborada pelo próprio autor da tese

A maioria dos indivíduos em medida de segurança em desinternação no Distrito Federal em 2013 residia com sua família. No caso daqueles que tiveram a medida extinta, 20 residiam com a família e 2 residiam em comunidades terapêuticas. Entre os indivíduos em desinternação, 13 residiam com a família e 3 residiam em comunidades terapêuticas. Além disso, um único paciente em desinternação residia em casa de passagem. Não é apenas o vínculo com a Justiça que é mantido entre as famílias dos pacientes e a Seção Psicossocial; como destaca uma das entrevistadas, "a vulnerabilidade social é a principal passagem de entrada para o sistema prisional do paciente psiquiátrico e também perpetua a manutenção do vínculo com a Justiça”" (ENTREVISTADA 3).

Além disso, o fato de a maioria dos pacientes em desinternação residirem com suas famílias não significa que essa situação seja algo livre de conflitos. Ao contrário do que poderia parecer, a maioria dos indivíduos em desinternação reside com suas famílias pela ausência de equipamentos públicos para abrigar os indivíduos em sofrimento mental. Quando da ausência de apoio familiar, a desinternação se retarda, como registrado por uma das entrevistas,

Quando não há apoio familiar, a desinternação se torna impossível. Assim, temos que criar alternativas de acolhimento. Nem sempre os pacientes têm perfil para residir na Casa de Passagem e por não ter Residências Terapêuticass no DF, temos que apelar para abrigos de idosos, Comunidades Terapêuticas vinculadas às Igrejas e até parentes de outros pacientes que se prontificam a receber algum interno. (ENTREVISTADA 2).

Esse cenário das moradias dos indivíduos em medida de segurança é bastante próximo daquele analisado no caso dos pacientes em medida de segurança acompanhados pelo Programa PAI-PJ, de Minas Gerais, e pelo Programa Paili, de Goiás. A maioria deles também 
residia com as famílias, e uma pequena quantidade residia nos Serviços Residenciais Terapêuticos (ver capítulo 5).

A rede de serviços substitutivos de saúde mental pode ser decisiva para auxiliar o processo de desinternação condicional das medidas de segurança. O Distrito Federal possui uma rede incompleta desses serviços (SANTIAGO, 2009; ZGIET, 2010), o que traz impactos para os pacientes em sofrimento mental de modo geral e para os em medida de segurança, em específico. Em 2013, havia 16 Centros de Atenção Psicossocial (CAPS) no Distrito Federal (DISTRITO FEDERAL, 2014). De acordo com a Portaria 336, de 2002, e de acordo com a população do Distrito Federal, a quantidade de CAPS no DF ainda é insuficiente (BRASIL, 2002). O Distrito Federal ainda possui o Instituto de Saúde Mental, que funciona tanto como uma casa de passagem quanto como um Centro de Convivência e, além disso, o DF tem um Hospital para internações psiquiátricas, o Hospital São Vicente de Paula (DISTRITO FEDERAL, 2014). No Distrito Federal, uma ausência importante de equipamento público dos serviços substitutivos de saúde mental é os Serviços Residenciais Terapêuticos, o que traria consequências imediatas para abrigamento e assistência aos indivíduos em desinternação das medidas de segurança.

Nos processos analisados dos indivíduos em desinternação, em três havia informação de que foi solicitado aos indivíduos em medida de segurança acesso ao auxílio-reabilitação do Programa De Volta para Casa. No Distrito Federal, em nenhum dos casos dos 23 indivíduos com a medida de segurança extinta houve a solicitação do auxílio. De acordo com informações da Secretaria de Estado de Saúde do Distrito Federal, em 2014, 179 pacientes recebiam o auxílio-reabilitação do Programa De Volta para Casa. O registro de onde os pacientes atendidos pelo Programa no Distrito Federal residem é de um período em que a capital federal contava com 185 pacientes no programa. Desses 185, 177 residiam com a família, 3 residiam sozinhos e 5 residiam em abrigos de longa permanência. Do total de pacientes atendidos pelo Programa De Volta para Casa em 2014 em 2013, apenas quatro são provenientes de medidas de segurança cumpridas na ATP-DF.

Há fragilidades no acesso às políticas de assistência social ou ao auxílio-reabilitação no Distrito Federal, como citado por uma das entrevistadas:

Normalmente orientamos as famílias a procurarem os benefícios assistenciais. Porém, algumas famílias têm dificuldades de finalizar o processo. Atualmente, estamos com problemas com o Programa De Volta para Casa, uma vez que o Ministério da Saúde alega não ter recursos para pagar novos beneficiários, mesmo que os pacientes estejam dentro dos critérios, como é o caso de três pacientes da Casa de Passagem do Instituo de 
Saúde Mental do DF, e um paciente que foi desinternado recentemente (ENTREVISTADA 5).

Não somente o auxílio-reabilitação, mas o próprio BPC encontra entraves para sua concessão aos indivíduos em medida de segurança. Dos 40 processos analisados, nenhum fazia referência a pacientes em medida de segurança que tenham feito a solicitação, muito menos tenham tido acesso ao BPC, a fim de obter uma renda mensal. Como analisado no terceiro capítulo, há uma normativa interna do INSS que proíbe a concessão do BPC para pessoas sob custódia do Estado. Esse amplo espectro "sob custódia do Estado" não consegue precisar as fases dinâmicas da desinternação condicional que podem ser necessárias de proteção social por meio de programas e serviços socioassistenciais. A não concessão do BPC para quem está em presídio ou em manicômio judiciário torna-se inflexível ao ponto de não haver concessão nem mesmo na fase desinternação, isto é, uma fase essencial em que a retomada da autonomia dos indivíduos depende de acesso a políticas para proteção da autonomia. Essa regra pode ser decisiva para a continuação da dependência dos indivíduos em medida de segurança: a proteção social fica vinculada, de um extremo ao outro, à tutela oferecida pelos manicômios judiciários e à sobrecarga das famílias.

\subsection{Políticas sociais e desinternação nas medidas de segurança: o familismo como dispositivo}

Como analisado anteriormente nas trajetórias de configuração das políticas de assistência social e de saúde mental, o familismo é um traço contemporâneo dessas duas políticas. Ele não mais se estrutura na ausência total do Estado na responsabilidade de provisões de proteção social aos cidadãos e de assistência em saúde, como ocorreu durante o período pré-Constituição de 1988. O familismo adentra o funcionamento das políticas sociais, metamorfoseando a formulação de suas bases de sustentação. $\mathrm{O}$ traço do familismo na assistência social e na saúde mental é uma das condições de existência das políticas sociais contemporâneas no cenário brasileiro.

No Brasil, a partir dos anos 1990 e 2000, o familismo deixou de ser o reflexo da ausência do Estado para se emoldurar em uma engenharia complexa de políticas sociais que dependem, para sua expansão, da presença da família. Isto é, o familismo não se origina mais apenas um espírito conservador que orienta as políticas sociais, mas emerge e se sustenta em um complexo circuito de avanços e retrocessos na expansão das políticas de assistência social e de saúde mental. Nas falas de todos os profissionais da Seção Psicossocial da VEP-DF, o 
familismo na fase de desinternação fica evidente como uma das dependências para o retorno à liberdade dos indivíduos em medida de segurança. E, quando da ausência das famílias, o processo de desinternação é impossibilitado. Uma das entrevistadas explicitou que, "quando não há apoio familiar, a desinternação se torna impossível” (ENTREVISTADA 1). A presença da família não só atende as necessidades dos indivíduos ao retornar para as redes familiares e comunitárias; é pré-requisito para a liberdade.

Nos capítulos 3 e 4, foi delineado que o familismo nas políticas de assistência social e de saúde mental se configura não apenas naquilo que é resultado da ausência do Estado na atenção às demandas dos cidadãos. O familismo estrutura-se a partir de novas bases exatamente no confronto a partir das reconfigurações necessárias de políticas existentes com o novo ordenamento jurídico e institucional dessas ações, mas também na sua relação com determinantes econômicos, forças históricas e culturais que ainda influenciam a remodelação das práticas que materializam as ações das duas políticas sociais. Foi caracterizado que o familismo nessas duas políticas assume três formas principais: o familismo do tipo compartilhamento, o familismo do tipo transferência e o familismo por omissão. No caso do familismo por compartilhamento têm-se os exemplos de todos os benefícios assistenciais garantidores de segurança de sobrevivência (rendimentos), em que atuação do Estado se dá de modo a compartilhar a responsabilidade pela segurança de renda com as famílias dos indivíduos. Isto é, o Estado promove a segurança de sobrevivência depois que a família comprovadamente não têm condições de fazê-lo: é o caso do Programa Bolsa-Família, do Benefício de Prestação Continuada e até mesmo do auxílio-reabilitação do Programa de Volta para Casa. Apesar de o Programa de Volta para Casa ser uma política da área da saúde, que garante segurança de renda aos portadores de sofrimento mental, assume como nas políticas da assistência social as mesmas características pelos critérios de renda familiar exigidos para sua execução.

A consequência do familismo do tipo compartilhamento é o fato de que essa característica na proteção social acaba gerando a compreensão de que a segurança de sobrevivência se aproxima mais de um dever familiar do que um direito do indivíduo. Isto é, o Estado não trata os indivíduos como fins em si mesmos, mas atua após a constatação de que a família não condições de fazê-lo (TAVARES, 2008). No momento da desinternação dos indivíduos em medidas de segurança, tal consequência se evidencia quando há poucos casos (apenas três dos 40 analisados) em que houve a busca pelos benefícios de transferência de renda para resultar na segurança de rendimentos a indivíduos que estão na fase de retorno à 
liberdade. O compartilhamento de responsabilidades entre Estado e famílias na tarefa de segurança de sobrevivência ou de rendimentos pode trazer consequências imediatas quando, pela ineficiência da política ou pela ausência da relação entre indivíduo em medida de segurança em desinternação e sua família, não há proteções aos indivíduos, o que leva à impossibilidade do retorno à liberdade.

O familismo do tipo transferência está mais presente na política de saúde mental. No caso do processo de desinstitucionalização provocado pela reforma psiquiátrica, grande parte das responsabilidades pela provisão de bem-estar aos indivíduos em sofrimento mental foi transferida às famílias dos pacientes. O ritmo com que os serviços substitutivos foram sendo criados no Brasil não atendeu de forma integral a todos os pacientes egressos dos manicômios, como analisado no capítulo 4 . O resultado imediato dessa transição incompleta fez recair sobre as famílias a atribuição para oferecer apoio aos indivíduos que, agora, não estão mais isolados nos manicômios, nos quais, durante quase duzentos anos, apartaram tais indivíduos de suas famílias e de suas comunidades ao mesmo tempo em que oferecia atenção às necessidades cotidianas dos pacientes no interior desses equipamentos. No estudo de caso do Distrito Federal, essa transferência de responsabilidade às famílias pode ser verificada quando a quase totalidade dos indivíduos na fase de desinternação residem com suas famílias: houve relatos dos profissionais envolvidos na fase de desinternação sobre o fato de que, se não houver apoio familiar para receber os indivíduos, não vai haver desinternação pela ausência de políticas e programas para atuar neste momento. É importante salientar que os próprios profissionais também relataram que esse trabalho de convencimento junto às famílias para receber os indivíduos em desinternação das medidas de segurança é desafiante e impede a desinternação em muitos casos.

Já o familismo do tipo omissão pode ser encontrado, principalmente pela ausência de políticas que ofereçam cuidados pessoais às pessoas em sofrimento mental. Essas políticas tanto poderiam partir da assistência social quando da política de saúde mental. Não são todas as pessoas em sofrimento mental que necessitam de cuidados cotidianos oferecidos por um cuidador pessoal. No entanto, quando há necessidade, ela é suprida pelos membros das famílias dos pacientes. $\mathrm{O}$ debate sobre políticas de cuidadores pessoais tem sido incipiente no Brasil para os casos de cuidado das pessoas com deficiência e das pessoas idosas (CRUZ, 2011; GUIMARÃES, 2008). Por sua vez, o acúmulo a respeito de propostas de políticas públicas para cuidados pessoais das pessoas em sofrimento mental é quase inexistente. No caso dos indivíduos em medidas de segurança em fase de desinternação, a necessidade de 
cuidadores pessoais pode ser premente devido à dependência institucional que os indivíduos podem assumir, exigindo que no retorno à liberdade a habilidade para o desempenho de tarefas cotidianas básicas pode levar tempo até ser adquirida e, portanto, tendo a necessidade auxílio de cuidadores pessoais. Além disso, a necessidade da continuidade do tratamento e acompanhamento tanto psiquiátrico quanto de atenção psicossocial pode contar com cuidadores pessoais que auxiliariam na atenção necessária para a continuação do tratamento medicamentoso, na realização de oficinas terapêuticas e de práticas cotidianas que favoreçam a continuidade do processo de recuperação durante o tratamento e acompanhamento psicossocial.

O familismo passa a adquirir uma racionalidade própria no interior do funcionamento das políticas de assistência social e de saúde mental a partir dos anos 2000. Parafraseando Foucault (1999), o familismo nas políticas sociais pode ser caracterizado como um dispositivo. Por dispositivo entende-se a rede de relações que pode ser estabelecida entre elementos heterogêneos: discursos, instituições, regramentos, leis, medidas administrativas, enunciados científicos, proposições filosóficas, morais, filantrópicas, o dito e o não dito (CASTRO, 2009; FOUCAULT, 1999). O dispositivo estabelece a natureza do nexo que pode existir entre esses elementos heterogêneos.

Se a episteme é o objeto da descrição arqueológica dos escritos de Foucault, o dispositivo é o objeto da descrição genealógica (CASTRO, 2009). Segundo Castro (2009), episteme aparece em alguns textos foucaultianos como saber ou saber teórico. Ela tem uma determinação temporal e geográfica, isto é, corresponde às condições de possibilidade de todo saber, em uma dada cultura e em um dado momento (CASTRO, 2009). Descrever a episteme é descrever a região intermediária entre os códigos fundamentais de uma cultura, os que regem sua linguagem, seus esquemas perceptivos, seus intercâmbios, suas técnicas, seus valores, a hierarquia das práticas e as teorias, científicas e filosóficas, que explicam todas essas formas de ordem (CASTRO, 2009). Por sua vez,

No caso do dispositivo, ele pode aparecer como programa de uma instituição, como elemento que pode justificar ou ocultar uma prática, ou como uma interpretação a posteriori dessa prática, oferecendo-lhe um campo novo de racionalidade (CASTRO, 2009). Trata-se de uma formação que, em um momento dado, teve por função responder a uma emergência. No caso do familismo nas políticas de assistência social e de saúde mental, a emergência tem a ver com o lugar e o momento em que essas duas políticas sociais se remodelaram a partir dos anos 1990 e, sobretudo, 2000. Para atender a necessidades sociais e promover assistência em 
saúde, a assistência social e a política de saúde mental conseguiram se modernizar por meio do compartilhamento legal e institucional de responsabilidade com as famílias. Desse modo, o dispositivo tem uma função estratégica (FOUCAULT, 1999). É possível perceber a função estratégica que o familismo cumpre nas políticas sociais ao fazer parte do conjunto das ações capitaneadas pelo poder público, completas e incompletas, articuladas ou desarticuladas - e não meramente pela ausência dessas ações públicas.

Além da estrutura de elementos heterogêneos, um dispositivo se define por sua gênese (CASTRO, 2009). A esse respeito, Foucault distingue dois momentos essenciais: um primeiro momento, o do predomínio do objeto estratégico; um segundo momento, a da constituição do dispositivo propriamente dito. $\mathrm{O}$ dispositivo, uma vez constituído, permanece como tal na medida em que tem lugar um processo de sobredeterminação funcional: cada efeito, positivo e negativo, desejado ou não desejado, entra em ressonância ou em contradição com os outros e exige um reajuste (CASTRO, 2009). Além do que, encontra-se também um processo de perpétuo preenchimento estratégico. No caso das políticas sociais voltadas para as pessoas em sofrimento mental, o familismo presente no momento da desinternação pode ser explicado pelo que Foucault estabelece como o perpétuo preenchimento estratégico do dispositivo. O familismo não apenas aparece como resultado das relações heterogêneas em determinado ponto da prática do poder, mas tem a capacidade de se estender no circuito familista, cumprindo com a função de preenchimento estratégico perpétuo no dispositivo.

Como dispositivo, o familismo cumpre um papel fundamental ao sedimentar as muitas incompletudes das políticas de saúde mental e de assistência. Analisar o alcance das políticas sociais é reconhecer a sua natureza e os seus desdobramentos, que se emaranham a outras práticas, saberes e instituições voltadas para o atendimento de necessidades humanas básicas. Quando o familismo presente nas políticas sociais refunda suas características e altera seu escopo, o alcance das políticas sociais se altera definitivamente. O familismo é um traço da natureza contraditória das políticas sociais em um estado capitalista que responde tanto aos interesses de ampliação da construção da autonomia dos sujeitos, mas, que também responde, às condições estruturais de manutenção das bases que sustentam o funcionamento do modo de produção capitalista que replica desigualdades. O familismo produziu uma ausência de proteção no alcance das políticas sociais de assistência e de saúde mental a ponto de gerar algo totalmente novo e até mesmo indesejado: os esquecidos dos manicômios judiciários. A situação dos esquecidos dos manicômios judiciários são os resíduos do familismo estruturante da lógica assistencial, tanto da saúde mental quanto da política de assistência social. 


\section{CONSIDERAÇÕES FINAIS}

Émile Durkheim (1975) analisou o famoso Caso Dreyfus, um escândalo político que dividiu a opinião de intelectuais, escritores e cientistas na França durante o final do século XIX. O caso tratava da condenação, em 1894, por alta traição de Alfred Dreyfus, um oficial de artilharia do exército francês. $\mathrm{O}$ acusado foi condenado em um processo com fraudes que correu em segredo. Na verdade, posteriormente se descobriu que Dreyfus era inocente: a condenação baseou-se em documentos falsos. Quando os oficiais de alta patente franceses perceberam o equívoco, buscaram ocultar o erro judicial.

Dreyfus foi condenado à prisão perpétua na Ilha do Diabo, na costa da Guiana Francesa. Em novembro de 1897, seu irmão Mathieu Dreyfus descobriu que Charles Esterhazy era o verdadeiro culpado. Em 1898, as provas da inocência de Dreyfus possibilitaram outro julgamento. No entanto, o nacionalismo exacerbado na França fez com que permanecesse a injusta sentença anterior, o que provocou a indignação do escritor Émile Zola, que expôs o escândalo e o trouxe a público no jornal literário L'Aurore, por meio de uma carta aberta ao presidente da República. O Caso Dreyfus dividiu a França entre os dreyfusards (os apoiadores de Dreyfus) e os anti-dreyfusards (opositores a ele). A disputa foi intensa, pois envolvia vários assuntos no clima controverso e agitado do então republicanismo e nacionalismo francês. De certa forma, essas divisões seguiam a linha de demarcação entre uma direita apoiando o retorno à monarquia e uma ala à esquerda apoiando a república.

Durkheim (1975) não discutiu o Caso Dreyfus em si, mas os desdobramentos dele e as perspectivas analíticas dos intelectuais que se colocaram pró e contra a condenação de Dreyfus. Para Durkheim, o caso revelou uma discussão mais profunda e latente na sociedade francesa: a doutrina do utilitarismo e do egoísmo se confundindo com uma má interpretação do individualismo. Durkheim afirma que é impossível qualquer vida em comum nas sociedades se não existirem interesses superiores aos interesses individuais. Ele parte dessa afirmação porque muitos dos argumentos favoráveis à manutenção da condenação de Dreyfus eram feitos em nome da defesa da ordem e dos interesses coletivos perante os interesses individuais em questão, como os do próprio Dreyfus.

No entanto, Durkheim defendeu que as discussões foram profundamente marcadas por uma grave confusão em atacar o individualismo, pois os intelectuais de ambos os lados estavam tratando de diferentes tipos de individualismo. Ele sustentou que, para além da forma de individualismo egoísta corretamente atacada de modo até virulento por intelectuais, 
inclusive como "uma verdadeira praga pública" (DURKHEIM, 1975), havia outro tipo de individualismo contra o qual seria mais difícil lutar: o individualismo defendido por Immanuel Kant e Jean-Jacques Rousseau, o mesmo da Declaração Universal dos Direitos do Homem. Pois, nesse tipo de individualismo, "a origem do mal estaria em toda conduta que tem como motivação apenas circunstâncias e interesses pessoais" (DURKHEIM, 1975, p. 237). Nas palavras de Kant, é possível ter certeza de estar agindo corretamente se os motivos que nos determinam dependerem não das circunstâncias particulares, mas da qualidade do ser humano in abstracto (DURKHEIM, 1975). Em termos mais simples, a única maneira moral de agir é aquela que pode convir a todos os seres humanos indistintamente, ou seja, por meio do afastamento dos interesses individuais, para agir de acordo com o que nossa condição humana exige, de forma comum a todos os semelhantes.

Para Durkheim (1975), dessa doutrina de Kant saíram tanto a ética impregnada de socialismo quanto a filosofia de Hegel, de quem Marx foi discípulo. Ele avança para demonstrar a solução para uma contradição aparente que poderia surgir de tais ideias. Durkheim questiona: como, dessa defesa da dignidade do indivíduo que advém de suas características individuais e das particularidades que o distinguem do próximo, não surge um egoísmo moral que impossibilitaria qualquer solidariedade? A esse questionamento fundamental, que está na origem de toda a sobreposição de perspectivas em torno da noção da individualidade e dignidade, Durkheim responde que todo indivíduo tem direito a essa individualidade e dignidade "porque há nele qualquer coisa de humanidade. É a humanidade que é respeitável e sagrada [...] e ela não está inserida nele. Está espalhada em todos os seus semelhantes [...]" (1975, p. 240). O individualismo assim concebido seria a defesa não do indivíduo empírico, mas do indivíduo em geral; não do egoísmo, mas de uma necessidade urgente de combater e atenuar todas as misérias humanas, com uma maior sede de justiça (DURKHEIM, 1975).

Desse modo, a defesa do individualismo, quer dizer, a defesa dos direitos de todos os indivíduos seria a defesa, ao mesmo tempo, dos interesses da sociedade, dos direitos humanos. Nessa perspectiva explicitada por Durkheim, a ação de um Estado ou de um governo republicano, mesmo que atendendo a interesses coletivos, não passa de um instrumento, um meio em vista de um fim para os interesses individuais de todos. Portanto, esse fim não pode ser o aniquilamento da individualidade em nome de interesses da coletividade. Embora, do ponto de vista filosófico a oposição entre indivíduo e sociedade possa ser um falso dualismo, como demonstrado por Durkheim, tal oposição possui 
consequências práticas no plano empírico. É o caso da engrenagem que permitiu o surgimento dos esquecidos dos manicômios judiciários.

Aqueles que estão à margem, que estão excluídos ou esquecidos não representam a imagem inversa no espelho que reflete aqueles que, do outro lado, estão incluídos e assimilados integralmente pela sociedade. Os esquecidos dos manicômios judiciários são parte do que constitui nossa humanidade. Eles não somente nos complementam pela humanidade compartilhada, mas definem a todos nós. A desumanidade na situação dos esquecidos não é o inverso da dignidade experimentada por quem se encontra em um extremo oposto. É, antes de tudo, parte da humanidade de todos aqueles que jamais experimentarão tal situação de absoluto e perpétuo desamparo. Paradoxalmente, os esquecidos acabam sendo parte daquilo que define nossa sociedade e todo o conjunto de valores, preceitos e práticas que caracterizam nossas instituições e forjam nossas existências singulares. Como salientou Durkheim, a humanidade está espalhada no conjunto de todos os seres humanos, e é ela quem nos lembra da humanidade dos esquecidos.

O que a doutrina da defesa social como justificativa para a emergência dos manicômios judiciários aniquila não é o fato de os loucos que cometem crimes representarem uma ameaça a todos os pressupostos para a sociabilidade e vida em comunidade. O que a doutrina da defesa social como justificativa ao encarceramento do louco aniquila é a possibilidade de reconhecer a humanidade desse sujeito. Os esquecidos dos manicômios judiciários não nos mostram que somos incapazes de construir uma sociedade que abarcará a todos. Eles nos mostram que, para nossa sociedade existir, é preciso coexistir com situações como o surgimento dos esquecidos que podem sedimentar, muito mais do que abalar, as condições de manutenção da nossa sociabilidade. O Caso Dreyfus foi a evidência do surto coletivo que tomou conta da França ao ponto de aniquilar os direitos de um indivíduo em nome dos interesses da coletividade. Os esquecidos dos manicômios judiciários são a evidência da incompletude das políticas sociais que não conseguem promover o tratamento de todos para proteger a dignidade de cada um, não vendo-os como fins em si mesmos, mas como meios para o bem da sociedade.

A hipótese que guiou esta tese buscou demonstrar o quanto o familismo nas políticas de assistência social e de saúde mental pode ser a causa do surgimento dos indivíduos nos manicômios judiciários que caem no esquecimento das famílias, do Estado e da sociedade. Para demonstrar essa hipótese foi preciso, antes de tudo, analisar por meio de uma recuperação genealógica os traços do familismo nos programas, políticas, ações e benefícios 
tanto da assistência social quanto da política de saúde mental. Os benefícios e programas da política de assistência social atravessaram um longo caminho, partindo de ações espontâneas e esparsas da sociedade civil, até se constituírem em ações de responsabilidade do Estado e assentadas sobre as bases que garantem a todos os cidadãos o direito à seguridade social. Por sua vez, a política de saúde mental reestruturou-se a partir dos anos 2000 na perspectiva de promover outro paradigma de atenção em saúde para superar o modelo manicomial que, durante quase dois séculos, atuou no Brasil causando uma série de violações de direitos dos indivíduos em sofrimento mental. O que foi demonstrado é que, em ambos os casos, de forma contraditória o familismo auxiliou no processo de modernização dessas duas políticas.

Para demonstrar o familismo nas duas políticas foi preciso ir além das afirmações legais, institucionais e programáticas, mas também buscar as pegadas e impressões do familismo decorrentes das afirmações infrajurídicas que se espraiam para comportamentos autorizados e não autorizados pelos arcabouços legais, políticos e institucionais que materializam o direito à assistência social e à saúde mental. Isto é, o empreendimento genealógico busca recuperar o que está por trás da configuração de determinados dispositivos que se formam paralelamente às estruturas normais e legais de uma determinada prática (FOUCAULT, 1999). O que oferece suporte ao familismo na assistência social e na saúde mental no Brasil não é apenas uma autorização expressa na lei ou em ações políticas da administração pública, mas, principalmente um emaranhado de situações supralegais com tendências históricas, traços culturais, valores políticos e saberes específicos que fazem nascer formas originais de práticas que superam as afirmações legais e jurídico-políticas tradicionais.

O método genealógico empregado na análise das políticas de assistência social e de saúde mental possibilitou a caracterização de três tipos principais de familismo: o familismo do tipo compartilhamento, o familismo do tipo transferência e o familismo por omissão do Estado. O familismo do tipo compartilhamento é o mais presente na política de assistência social. Isso significa que grande parte das provisões sociais e materiais para atendimento das necessidades básicas dos indivíduos são de responsabilidade compartilhada entre o Estado e as famílias. Os exemplos mais evidentes são as políticas de transferência de renda que garantem a segurança de sobrevivência. Principalmente, o BPC e o Programa Bolsa Família são executados desde que a família não tenha condições de manter a segurança de renda de seus membros. Isto é, antes de ser um direito individual a ser protegido por uma política social, a segurança de renda se transforma em uma obrigação familiar. Somente depois de declarada a insuficiência da família em garantir o sustento de seus membros é o que Estado 
assume tais responsabilidades. Já o familismo do tipo transferência é mais encontrado na política de saúde mental. Essa característica foi assumida, principalmente após a publicação da Lei 10.216, em 2001, que instituiu as diretrizes legais para impulsionar a reforma psiquiátrica, ou seja, a substituição do modelo manicomial pela criação de serviços substitutivos de saúde mental em meio aberto. No caso brasileiro, a mudança de paradigma para o regime aberto dos serviços substitutivos só foi possível porque houve uma transferência dos manicômios para o ambiente das famílias como os entes responsáveis por oferecer apoio e assistência aos indivíduos. As famílias passaram a assumir grande parte das responsabilidades de assistência cotidiana aos indivíduos quando estas deveriam ter sido ofertadas por políticas públicas efetivas, como os Programas de Volta para Casa, os Serviços Residenciais Terapêuticos, Casas de passagem, Centros de Convivência, etc. A transferência ocorre não apenas por ausência do Estado quando as políticas são ineficientes, mas até mesmo por afirmações legais que transferem algumas responsabilidades às famílias de forma expressa, como são alguns princípios assumidos na Lei 10.216 que apostam no tripé "trabalho, família e comunidade" como um mecanismo auxiliar aos serviços substitutivos.

Por fim, o familismo do tipo omissão é aquele caracterizado pela ausência total do Estado em ofertar ações de bem-estar social, o que acaba sendo assumido integralmente pelas famílias. A omissão do Estado significa que alguma esfera de atenção necessária de política pública de responsabilidade do Estado ainda não ascendeu ao patamar de intervenção pública por meio da materialização de uma política social. Diferentemente do familismo do tipo transferência - em que a família atua porque há ausência parcial de políticas ou há transferência de responsabilidades às famílias expressa legalmente - , no familismo do tipo omissão, as famílias assumem integralmente as funções de cuidado e assistência dos indivíduos por omissão do Estado em dispor de políticas públicas para casos específicos, como são as situações de necessidade de cuidadores pessoais para os indivíduos em sofrimento mental e ausência de políticas intersetoriais específicas para a fase de desinternação das medidas de segurança. Desse modo, esses três tipos de familismo nas políticas de assistência social e de saúde mental no país conforma uma engrenagem específica, cujas responsabilidades para ofertar bens e serviços que promovam bem-estar social têm características mistas e complexas de atuação dos Estados e da família. Essas características dão suporte ao que podemos denominar de circuito familista nas políticas sociais.

O circuito familista presente nas políticas de assistência social e de saúde mental se 
manifesta porque não há apenas ausência total do Estado em dispor de políticas públicas para atender as necessidades e oferecer atenção em saúde aos indivíduos em sofrimento mental. O circuito familista na assistência e na saúde mental passou a ser uma disposição complexa cujas responsabilidades de provisão material e de bem-estar ora estão como responsabilidade do Estado compartilhada com as famílias, ora algumas ações são assumidas integralmente pelos arranjos familiares. A condição familista, isto é, a relação complexa de compartilhamento de atribuições entre Estado e família na oferta de bens, serviços e apoio para o atendimento de bem-estar dos indivíduos ressignificou o papel das políticas sociais. Inclusive, foi uma das condições necessárias para a expansão da política de assistência social como um direito de seguridade social e da saúde mental como estruturação de uma rede psicossocial em meio aberto para substituir o asilamento do modelo manicomial. A condição familista limita o alcance das duas políticas a todos de quem delas necessitar, mas, paradoxalmente, o familismo foi um dos elementos que permitiu essas duas políticas se assentarem sobre novas bases e se expandirem a partir dos anos 1990 e 2000.

Para os indivíduos em medida de segurança, o familismo pode ser decisivo para a continuação da internação indevida nos manicômios judiciários. A fase da desinternação condicional das medidas de segurança é um momento de articulação entre diversas políticas, como os serviços substitutivos de saúde mental em meio aberto, os programas e benefícios de assistência social e até mesmo de ações de educação e de trabalho e emprego para que possam promover contextos de autonomia aos indivíduos em retorno à liberdade. Quando as políticas sociais, de modo geral, e a de assistência social e a de saúde mental, em particular, dependem da condição familista para se estruturarem, a ausência da família na fase de desinternação dos indivíduos em medida de segurança compromete a proteção social desses indivíduos. Tal comprometimento chega ao ponto de a continuação da internação ser a alternativa que resta para que o acesso a necessidades básicas e a continuidade do acompanhamento psiquiátrico sejam ofertados pelos estabelecimentos de custódia e tratamento psiquiátrico. O fato de o BPC não ser garantido aos indivíduos em sistemas carcerários pode ser a evidência de que, por meio de uma compreensão limitada da assistência social, tem-se a compreensão de que as necessidades básicas dos cidadãos podem ser atendidas por uma instituição prisional. Disso decorre que a assistência social se limita ao objetivo de promover apenas a segurança de sobrevivência e a de rendimentos, algo já superado legal e politicamente desde 2004.

Na fase de desinternação das medidas de segurança no Distrito Federal, o papel das famílias dos indivíduos em sofrimento mental é emblemático por vários motivos. Em 
primeiro lugar, uma falsa contradição se anunciaria: os profissionais da VEP afirmaram que sem a presença da família, não é possível haver desinternação. Por sua vez, a quase totalidade dos indivíduos em desinternação ou com as medidas já extintas residem com seus familiares. Esse dado poderia contradizer a hipótese testada neste estudo de que o familismo causa a não desinternação dos indivíduos em medida de segurança já aptos ao retorno à liberdade. Entretanto, ao se analisar a rede de atenção em saúde mental e os serviços de assistência social disponíveis para auxiliar os indivíduos em medida de segurança durante a desinternação no Distrito Federal constatam-se praticamente a inexistentes deles — o que faz com que a presença da família torna-se pré-requisito para oferecer apoio e assistência aos indivíduos. Além disso, houve relatos de que, dada a ausência de políticas públicas para favorecer a proteção social dos indivíduos em desinternação, há ocorrência até mesmo de famílias de outros indivíduos em medidas de segurança se oferecerem para receber aqueles em desinternação.

Em segundo lugar, o fato de os indivíduos em desinternação residirem com suas famílias não demonstra que a hipótese do familismo não tem força para explicar o surgimento dos esquecidos dos estabelecimentos de custódia e tratamento psiquiátrico. Foi demonstrado que o familismo metamorfoseou inclusive os trâmites administrativos para a desinternação condicional. Foi verificado que a ausência de políticas públicas ou apoios de terceiros, como os da família, provocou a alteração da ordem dos trâmites processuais para a desinternação das medidas de segurança no Distrito Federal. As fases para o cumprimento das medidas são as seguintes: 1. início da internação após sentença de medida de segurança, 2. cumprimento do período mínimo determinado na sentença, 3. elaboração anual do exame de cessação de periculosidade após término do período mínimo de internação, 4. cessação da periculosidade atestada, 5. sentença de desinternação, 6. desinternação condicional, 7. fím do período da desinternação condicional após um ano e, por último, 8. extinção da medida de segurança. É possível afirmar que o familismo provocou uma alteração dos procedimentos entre as fases quatro e cinco no Distrito Federal.

Os dados demonstram que, depois da cessação da periculosidade atestada por perícia psiquiátrica e antes de o juiz declarar a sentença de desinternação, a Seção Psicossocial da VEP dá início aos trabalhos de preparação para desinternação. Dentre as atividades realizadas pela Seção Psicossocial, tem-se o intenso trabalho de contato e preparação das famílias para receber os indivíduos, além de articulação dos serviços — quando existem — de saúde mental e de assistência social necessários para cada caso. Somente após essa antecipação da VEP no 
trabalho realizado junto às famílias é que o juiz declara a sentença de desinternação. Isto é, o tempo curto entre a declaração da sentença de desinternação e a desinternação condicional iniciada (média de três meses no Distrito Federal em 2013) e até mesmo a baixa quantidade de indivíduos (apenas 17\% dos em medidas de segurança da ATP-DF em 2011) em condições de desinternação com a sentença de desinternação declarada no Distrito Federal - como levantado no estudo censitário (DINIZ, 2012), pode ser explicado porque, antes, foi realizada a preparação para a desinternação pela Seção Psicossocial. Se este trabalho com as famílias não se inicia previamente, a desinternação pode ser retardada. Ao final, o tempo entre a sentença de desinternação e a desinternação em si é curto, mas o tempo entre a cessação da periculosidade e a sentença de desinternação pode se estender. Isto é, a presença da família não facilita a desinternação no Distrito Federal, como os dados da maioria dos indivíduos estarem com suas famílias poderiam inicialmente indicar. Pelo contrário. A dependência da atuação das famílias para receber os indivíduos em desinternação, devido à ausência de políticas públicas que o façam, fez com que o trabalho de preparação com os arranjos familiares começasse antes mesmo de declarada a sentença de desinternação pelo juiz.

Em terceiro lugar, na fase da desinternação acompanhada no Distrito Federal uma relação entre as famílias e o sistema de Justiça chamou a atenção. Alguns profissionais da VEP declararam haver uma dependência criada entre os familiares dos indivíduos em desinternação e o sistema de Justiça representado pela atuação da VEP. É muito comum as famílias procurarem a Vara de Execução para a solução dos mais variados desafios encontrados pelos indivíduos em seu cotidiano da desinternação. A presença frágil das redes de suporte tanto da família quanto da rede socioassistencial e dos serviços substitutivos de saúde mental faz com que os indivíduos não consigam romper a dependência do suporte oferecido pela Justiça, reforçando o circuito familista existente entre a segurança pública, as políticas sociais e a família para a proteção social dos indivíduos em desinternação. O Serviço de Atenção Integral à Família da política de assistência social, as equipes de Saúde da Família da rede pública de saúde e a cobertura dos serviços substitutivos da saúde mental, como as equipes dos Centros de Atenção Psicossocial, deveriam ser as referências para atendimento dessas necessidades. Entretanto, a inexistência ou a presença parcial delas reforça o universo dos indivíduos em medidas de segurança como uma temática que tem na segurança pública ainda a sua centralidade. Esse é um aspecto que dificulta ainda mais o processo de desfamiliarização das políticas de assistência social e de saúde mental.

A desfamiliarização das políticas sociais ocorre quando o Estado assume 
responsabilidades de provisão social e material dos cidadãos e efetiva políticas de bem-estar social que, por ora, têm sido assumidas pelas famílias (ESPING-ANDERSEN, 2000). Isto é, a desfamiliarização é o processo de enfraquecimento do familismo. A desfamiliarização depende de contextos históricos, culturais e econômicos que a favoreçam. Não depende apenas de afirmações legais e políticas. O caso brasileiro é emblemático nesse sentido, dado que as políticas sociais passaram a assumir novos paradigmas com a promulgação da Constituição Federal de 1988, ampliando as condições de exercício e desfrute da cidadania quando as políticas sociais promovem autonomia aos sujeitos. Entretanto, tais mudanças no arcabouço jurídico não foram suficientes para que as políticas sociais rompessem com características limitantes do passado. Por uma análise das políticas de assistência social e de saúde mental, foi possível perceber o quanto é desafiante o processo de desfamiliarização das políticas quando afirmações legais não são suficientes para desinterditar práticas arraigadas que sustentam outros modelos de atuação para as políticas sociais. No caso dos indivíduos em medida de segurança, os desafios se intensificam porque a relação familiar para oferecer apoio e assistência aos indivíduos em sofrimento mental muitas vezes são vistas como condições para manutenção do convívio comunitário e adesão mais comprometida com os acompanhamentos de saúde.

A investigação sobre a presença do familismo nas políticas de assistência social e de saúde mental como formas que decididamente influenciam na fase de desinternação dos indivíduos em medida de segurança, ao ponto de mantê-los indevidamente nos manicômios judiciários, visa estabelecer essa conexão: o ponto em que as funções de apoio, afeto e assistência oferecidas pelas famílias aos indivíduos em sofrimento mental se articulam a um familismo nas políticas sociais para produzir formas de abandono dos indivíduos em medida de segurança. As famílias são as instâncias que recebem os indivíduos em sofrimento mental, representando a tutela familiar necessária na fase de liberdade condicional. No entanto, as famílias são as instâncias que, responsáveis por engatar os sujeitos dos manicômios à vida comunitária e familiar, podem ser tão fundamentais ao jogo do funcionamento das medidas de segurança que a sua falta provoca alteração do cumprimento jurídico da sentença, prolongando a permanência dos indivíduos nas instituições correcionais-asilares. No jogo do familismo das políticas sociais voltadas aos indivíduos em medida de segurança, a família ao mesmo tempo destrava e interdita o processo de construção de contextos de autonomia dos sujeitos aptos a retornarem à liberdade, fazendo valer o controle sobre o sujeito em sofrimento mental. 
É possível afirmar que os esquecidos nos manicômios judiciários são a ruptura na regressão infinita da história que sempre descreveu e tratou os loucos como um problema de família. Antes de ser a fratura exposta do nosso processo de republicanização, pelo amadurecimento incompleto das políticas de assistência social e de saúde mental, os esquecidos são os vestígios do nosso Estado que não se governamentalizou. Nos últimos anos, a transição das políticas de saúde mental e de assistência social não conseguiu romper com os traços conservadores de práticas que ainda compartilham responsabilidades com as famílias para sua execução e submetem os indivíduos ao desamparo jurídico e social. Os esquecidos são o ponto de inflexão dessas duas políticas que não amadureceram ao ponto de promover a inteira desfamiliarização necessária para demarcar os limites e as possibilidades de atuação dos governos no papel de potencializar a proteção social dos indivíduos.

Os esquecidos dos manicômios judiciários, uma vez refratários da lógica penal, agora são refratários também do ambiente de suas famílias e das políticas sociais. Há uma relação de difícil superação entre o indivíduo louco que comete crimes e sua família pelo conflito no interior do crime familiar e da assistência quase integral direcionada aos indivíduos que fica a cargo, quase sempre, dos arranjos familiares. A tragédia é que grande parte dos indivíduos em medida de segurança já não tem laços com suas famílias. Há ainda uma esperança por se concretizar a respeito da Lei Antimanicomial, de 2001, que enfim havia anunciado a cidadania do louco, sendo o atendimento de suas necessidades básicas, a partir de então, responsabilidade das políticas públicas encampadas pelo Estado. Essa esperança ainda latente não foi capaz de subverter o espírito do familismo que sustenta a relação entre o Estado e os loucos, deixando a cargo das famílias a proteção social desses indivíduos, desses esquecidos, desses desamparados perpétuos. 


\section{REFERÊNCIAS BIBLIOGRÁFICAS}

ALMEIDA, Francis M. de. Heranças perigosas: arqueogenealogia da "periculosidade" na legislação penal brasileira. 2005. Dissertação (Mestrado em Sociologia) — Universidade Federal do Rio Grande do Sul, Porto Alegre.

AMARANTE, Paulo. Psiquiatria social e reforma psiquiátrica. Rio de Janeiro: Fiocruz, 1994.

ARANTES, Esther Maria de Magalhães. Os rostos da criança no Brasil. In: PILOTI, Francisco; RIZZINI, Irene (org.). A arte de governar crianças: a história das políticas sociais, da legislação e da assistência à infância no Brasil. Rio de Janeiro: Instituto Interamercano del Niño; Editora Universitária Santa Úrsula; Amais Livraria e Editora, 1995.

ARAÚJO, Emanuel. O teatro dos vícios: transgressão e transigência na sociedade colonial. Rio de Janeiro: José Olympio, 1993.

ARBEX, Daniela. Holocausto brasileiro: genocídio: 60 mil mortos no maior hospício do Brasil. São Paulo: Geração, 2013.

ARISTÓTELES. A política. São Paulo: Escala, 2000. (Coleção Grandes Obras do Pensamento Universal).

BARRETO, Tobias. Algumas ideias sobre o chamado fundamento do direito de punir. 2. ed. In: . Menores e loucos no Direito Criminal. Brasília: Senado Federal, 2003

BARROS-BRISSET, Fernanda Otoni. Um dispositivo conector - relato de experiência do PAIPJ/MG, uma política de atenção integral ao louco infrator, em Belo Horizonte. Revista Brasileira de Crescimento e Desenvolvimento Humano, v. 20, n. 1, 2010.

BEHRING, Elaine; BOSCHETTI, Ivanete. Política social: fundamentos e história. São Paulo: Cortez, 2008.

BOSCHETTI, Ivanete. Seguridade social e trabalho: paradoxos na construção das políticas de previdência e assistência social no Brasil. Brasília: LetrasLivres; Editora da UnB, 2006.

BOSI, Alfredo. Dialética da colonização. 4. ed. São Paulo: Cia. das Letras, 1996.

BRASIL. Arquivo Nacional. Dossiê. In: Dicionário brasileiro de terminologia arquivística. Rio de Janeiro: Arquivo Nacional, 2005.

Decreto-Lei 2.848, de 7 de dezembro de 1940. Código Penal. Rio de Janeiro, 1940. Disponível em: <http://www.planalto.gov.br/ccivil_03/decreto-lei/Del2848.htm>. Acesso em: 9 dez. 2010.

Lei 8.742, de 7 de dezembro de 1993. Dispõe sobre a Lei Orgânica da Assistência Social. Diário Oficial da União, Brasília, 8 dez. 1993. 
Lei 9.533, de 10 de dezembro de 1997. Autoriza o Poder Executivo a conceder apoio financeiro a municípios que instituírem programas de garantia de renda mínima associados a ações $\quad$ socioeducativas. Disponível em: <http://www.planalto.gov.br/ccivil_03/leis/L9533.htm>. Acesso em: 30 nov. 2014.

Lei 9.867, de 10 de novembro de 1999. Dispõe sobre a criação e funcionamento das cooperativas sociais visando a integração social dos cidadãos. Disponível em: <http://www.planalto.gov.br/ccivil_03/Leis/L9867.htm>. Acesso em 20 de setembro de 2014.

Lei 10.216, de 6 de abril de 2001. Dispõe sobre a proteção e os direitos das pessoas portadoras de transtornos mentais e redireciona o modelo assistencial em saúde mental. Diário Oficial da União, Brasília, 9 abr. 2001. Disponível em: <http://www.planalto.gov.br/ccivil_03/leis/leis_2001/110216.htm>.Acesso em: 10 jul. 2012.

Lei 10.708, de 31 de julho de 2003. Institui o auxílio-reabilitação psicossocial para pacientes acometidos de transtornos mentais egressos de internações. Diário Oficial da União, Brasília, 1. $^{\circ}$ ago. 2003. Disponível em: <http://www.planalto.gov.br/ccivil_03/Leis/2003/L10.708.htm>. Acesso em: 10 nov. 2012.

Lei 12.403, de 4 de maio de 2011. Altera dispositivos do Decreto-Lei n ${ }^{0} 3.689$, de 3 de outubro de 1941 - Código de Processo Penal, relativos à prisão processual, fiança, liberdade provisória, demais medidas cautelares, e dá outras providências. Diário Oficial da União, Brasília, 5 maio 2011a. Disponível em: <http://www.planalto.gov.br/ccivil_03/_ato2011-2014/2011/lei/112403.htm> Acesso em: 26 nov. 2011.

Lei 12.435, de 6 de julho de 2011. Altera a Lei 8.742, que dispõe sobre a organização da Assistência Social. Diário Oficial da União, Brasília, 7 jul. 2011b. Disponível em: <http://www.planalto.gov.br/ccivil_03/_Ato2011-2014/2011/Lei/L12435.htm>. Acesso em: 30 nov. 2014.

- Ministério da Educação. Pronatec. Brasília, 2014a. Disponível em: <http://pronatec.mec.gov.br/>. Acesso em: 30 out. 2014.

Relatório da Pesquisa Loucura e Direito Penal: uma Análise Crítica das Medidas de Segurança. Brasília, 2010a. (Projeto Pensando o Direito).

Ministério da Justiça. Resolução 4, de 30 de julho de 2010. Dispõe sobre as diretrizes nacionais de atenção aos pacientes judiciários e execução de medidas de segurança. Brasília, $2010 b$.

Resolução 5, de 4 de maio de 2004. Dispõe a respeito das diretrizes para ocumprimento das medidas de segurança, adequando-se à previsão contida na Lei n. 10.216, de 6 de abril de 2001. Brasília, 2004a. Disponível em: $<$ http://portal.mj.gov.br/cnpcp/main.asp?View=\{28D9C630-49B2-

406B91600C04F4BDD88E\}>. Acesso em: 13 out. 2010. 
. Ministério da Justiça. Departamento Penitenciário Nacional. Censo Nacional dos Estabelecimentos de Custódia e Tratamento Psiquiátrico do Brasil. Brasília, 2012.

. Ministério da Saúde. Portaria 106, de 11 de novembro de 2000. Institui os Serviços Residenciais Terapêuticos. Brasília, 2000. Disponível em: <http://dtr2004.saude.gov.br/susdeaz/legislacao/arquivo/27_Portaria_106_de_11_02_2000.pdf>. Acesso em: 5 nov. 2012.

\begin{tabular}{llcl}
\multicolumn{4}{c}{ Portaria 336, de 2002. Estabelece os CAPS I, CAPS II, CAPS III, CAPS i II e CAPS } \\
$\mathrm{ad}$ & II. & Brasília, & 2002.
\end{tabular} <http://dtr2001.saude.gov.br/sas/PORTARIAS/Port2002/Gm/GM-336.htm>. Acesso em: 30 nov. 2014.

eletrônico.

Saúde mental em dados 10. Brasília, ano VII, n. 10, mar. 2012a. Informativo

. Histórico de cobertura da saúde da família. Brasília, 2014b. Disponível em: <http://dab.saude.gov.br/portaldab/historico_cobertura_sf.php〉. Acesso em: 30 set. 2014.

Portaria 2.029, de 24 de agosto de 2011. Institui a Atenção Domiciliar no âmbito do Sistema Único de Saúde. Brasília, 2011c. Disponível em: <http://bvsms.saude.gov.br/bvs/saudelegis/gm/2011/prt2029_24_08_2011.html>. Acesso em: 30 set. 2014.

. Programa de Atendimento médico domiciliar já atende em 20 estados brasileiros. Brasília, 2012b. Disponível em: <http://www.brasil.gov.br/saude/2012/11/programa-deatendimento-medico-domiciliar-ja-atende-em-20-estados-brasileiros $>$. Acesso em: 30 set. 2014.

. Ministério do Desenvolvimento Social e Combate à Fome. Política Nacional de Assistência Social. Brasil, 2004b.

BRITTO, Renata Corrêa. A internação psiquiátrica involuntária e a Lei 10.216/01: reflexões acerca da garantia da proteção aos direitos da pessoa com transtorno mental. Dissertação (Mestrado em Saúde Pública) — Escola Nacional de Saúde Pública, Rio de Janeiro, 2004.

BUCCI, Maria Paula Dallari. O conceito de política pública em direito. In: . (org.). Políticas públicas: reflexões sobre o conceito jurídico. São Paulo: Saraiva, 2006.

CAMARANO, Ana Amélia. Cuidados de longa duração para a população idosa: um novo risco social a ser assumido? In: HIRATA, Helena; GUIMARÃES, Nadya (org.). Cuidado $e$ cuidadoras: as várias faces do trabalho do care. São Paulo: Atlas, 2012.

CAMPELlO, Tereza; NERI, Marcelo (org.). Programa Bolsa Família: uma década de inclusão e cidadania. Brasília: Ipea, 2013.

CARRARA, Sérgio. A história esquecida: os manicômios judiciários no Brasil. Revista Brasileira de Crescimento e Desenvolvimento Humano, v. 20, n. 1, p. 16-29, 2010. 
Crime e loucura: o aparecimento do manicômio judiciário na passagem do século. Rio de Janeiro: EdUERJ; São Paulo: Edusp, 1998.

CASTEL, Robert. A insegurança social: o que é ser protegido? Petrópolis: Vozes, 2005.

A ordem psiquiátrica: a idade de ouro do alienismo. Rio de Janeiro: Graal, 1978.

As metamorfoses da questão social: uma crônica do salário. Tradução de Iraci Poleti. 5. ed. Petrópolis: Vozes, 1995.

Rumo às novas fronteiras da medicina mental. In: FIGUEIRA, Sérvulo Augusto. Psicanálise e ciências sociais. Rio de Janeiro: Francisco Alves, 1980.

CASTRO, Edgardo. Vocabulário de Foucault. Tradução de Ingrid M. Xavier, revisão técnica de Walter Kohan e Alfredo Veiga-Neto. Belo Horizonte: Autêntica, 2009.

CASTRO, Viveiros de. A nova escola penal. Rio de Janeiro: Jacinto Ribeiro dos Santos Editor, 1894.

CHARMAZ, Kathy. A construção da teoria fundamentada: guia prático para análise qualitativa. Porto Alegre: Artmed; Bookman, 2009.

COELHO, Marilene. Imediaticidade na prática profissional do assistente social. In: FORTI, Valeria; GUERRA, Yolanda. Serviço social: temas, textos e contextos. Rio de Janeiro: Lumen Juris, 2013.

COHEN, Gerald. El marxismo y la explicación functional. In: ROEMER, John E. (org.). El marxismo: una perspectiva analítica. México: Fondo de Cultura Económica, 1989. p. 252266.

COSTA, Jurandir Freire. Ordem médica e norma familiar. Rio de Janeiro: Graal, 1979.

CRESWELL, John. Projeto de pesquisa: métodos qualitativo, quantitativo e misto. Porto Alegre: Artmed - Bookman, 2007.

CUNHA, Maria Clementina Pereira. O espelho do mundo: Juquery, a história de um asilo. Rio de Janeiro: Paz e Terra, 1986.

CUNHA, Murilo Bastos da; CAVALCANTI, Cordélia Robalinho de Oliveira. Dossiê. In: Dicionário de biblioteconomia e arquivologia. Brasília: Briquet de Lemos, 2008.

CRUZ, Deusina Lopes da. Família, deficiência e proteção social: mães cuidadoras e os serviços do Sistema Único da Assistência Social. 109 f. Monografia (Especialização em Gestão de Políticas Públicas de Proteção e Desenvolvimento Social). Escola Nacional de Administração Pública - ENAP - Brasília, 2011.

DAGNINO, Roberto. Metodologia de análise de políticas públicas. Buenos Aires: Organización de Estados Iberoamericanos, 2000. 
DECCA, Maria Auxiliadora Guzzo de. A vida fora das fábricas: cotidiano operário em São Paulo - 1927-1934. Dissertação (Mestrado em História) — Universidade Estadual de Campinas, Campinas, 1983.

DELEUZE, Gilles. Conversações. São Paulo: Editora 34, 2000.

DELGADO, Pedro Gabriel. As razões da tutela: psiquiatria, justiça e cidadania do louco no Brasil. Rio de Janeiro: Te Corá, 1992.

DEL PRIORE, Mary. História do amor no Brasil. São Paulo: Contexto, 2006.

DI GIOVANNI, Geraldo. Sistemas de proteção social: uma introdução conceitual. In: Reforma do Estado e políticas de emprego no Brasil. Campinas: Editora Unicamp, 1998.

DINIZ, Debora. A custódia e o tratamento psiquiátrico no Brasil - Censo 2011. Brasília: Editora da UnB; LetrasLivres, 2012.

DINIZ, Debora; SQUINCA, Flávia; MEDEIROS, Marcelo. Deficiência, cuidado e justiça distributiva. In: COSTA, Sérgio; FONTES, Malu; SQUINCA, Flávia. Tópicos em bioética. Brasília: LetrasLivres, 2006. p. 82-94.

DISTRITO FEDERAL. Secretaria de Estado de Saúde do Distrito Federal. Diretoria de Saúde Mental. Acesso em <http://www.saude.df.gov.br/programas/536-diretoria-de-saudemental-disam.html>. Acesso em 20 out. 2014.

Tribunal de Justiça do Distrito Federal e Territórios. Vara de Execuções Penais. Brasília, 2014. Disponível em: <http://www.tjdft.jus.br/cidadaos/execucoes-penais/vep>. Acesso em: 20 out. 2014.

DONZELOT, Jacques. A polícia das famílias. Rio de Janeiro: Graal, 1973.

DRAIBE, Sônia; AURELIANO, Liana. A especificidade do welfare state brasileiro. In: MPAS/CEPAL. Economia e desenvolvimento, n. 3. Brasília, 1989. p. 120-178. (Item II: A Historicidade da Política Social Brasileira).

DUARTE, Robson; DIAS, Diego. A intersetorialidade entre o CAPS e o CRAS no município de Esmeraldas: um relato de experiência. Cadernos Brasileiros de Saúde Mental, v. 4, n. 10, p. 237-240, 2012.

DURKHEIM, Émile. O individualismo e os intelectuais. In: A ciência social e a ação. São Paulo: Difel, 1975. Publicado originalmente em 1909.

DWORKIN, Ronald. A virtude soberana: a teoria e a prática da igualdade. Tradução de Jussara Simões. São Paulo: Martins Fontes, 2005.

ELSTER, Jon. Marxism, functionalism, and game theory. Theory and Society, v. 11, n. 4, p. 453-482, 1982.

ENGEL, Magali Gouveia. Os delírios da razão: médicos, loucos e hospícios (Rio de Janeiro, 1830-1930). Rio de Janeiro: Fiocruz, 2001. 
ESCOREL, Sarah; TEIXEIRA, Luiz Antônio. História das políticas de saúde no Brasil de 1822 a 1963: do império ao desenvolvimentismo populista. In: GIOVANELA, Lígia et al. Políticas e sistema de saúde no Brasil. Rio de Janeiro: Fiocruz, 2008.

ESPING-ANDERSEN, Gøsta. As três economias políticas do welfare state. Lua Nova, n. 24, p. 85-116,1991. Disponível em: <http://www.scielo.br/scielo.php?script=sci_arttext\&pid=S0102-64451991000200006>. Acesso em: 30 nov. 2014.

Fundamentos sociales de las economias post-industriales. Barcelona: Ariel, 2000.

FALEIROS, Vicente de Paula. O que é política social? São Paulo: Brasiliense, 1986. (Coleção Primeiros Passos).

FAORO, Raymundo. República inacabada. Rio de Janeiro: Globo, 2007.

FAUSTO, Boris. História concisa do Brasil. São Paulo: EdUSP, 2001.

FLEISCHACKER, Samuel. Uma breve história da justiça distributiva. São Paulo: Martins Fontes, 2006.

FOUCAULT, Michel. A arqueologia do saber. Rio de Janeiro: Forense Universitária, 2000.

A evolução da noção de indivíduo perigoso na psiquiatria legal do século XIX: poder e saber. In: Ética, sexualidade e política. São Paulo: Forense Universitária, 2010a. (Coleção Ditos e Escritos, V).

A loucura e a sociedade. In: Problematização do sujeito: psicologia, psiquiatria e psicanálise. Rio de Janeiro: Forense Universitária, 2010b. (Coleção Ditos e Escritos, I).

A vida dos homens infames. In: Estratégia, poder-saber. Rio de Janeiro: Forense Universitária, 2003a. (Ditos e Escritos, IV). Publicado originalmente em 1977.

. História da loucura na idade clássica. São Paulo: Perspectiva, 2005.

. História da sexualidade I: a vontade de saber. Rio de Janeiro: Graal, 1999.

. Microfísica do poder. Rio de Janeiro: Graal, 2003b.

1974.

O poder psiquiátrico. São Paulo: Martins Fontes, 2006. Publicado originalmente em . Os anormais. São Paulo: Martins Fontes, 2001. Publicado originalmente em 1975.

Segurança, território, população. São Paulo: Martins Fontes, 2008. Publicado originalmente em 1978.

Vigiar e punir: nascimento da prisão. Petrópolis: Vozes, 1977. 
FREY, Klaus. Políticas públicas: um debate conceitual e reflexões referentes à prática da análise de políticas públicas no Brasil. Planejamento e Políticas Públicas, n. 21, p. 211-259, 2000 .

GARLAND, David. A cultura do controle: crime e ordem social na sociedade contemporânea. Rio de Janeiro: Revan, 2008.

GERSCHMAN, Silvia. A democracia inconclusa: um estudo da Reforma Sanitária brasileira. Rio de Janeiro: Fiocruz, 2004.

GONÇALVES, Cláudia Maria da Costa. Assistência social às famílias nas Constituições brasileiras. Curitiba: Juruá, 2009.

GOYARD-FABRE, Simone. O que é democracia. São Paulo: Martins Fontes, 2003.

GRAY, David. Pesquisa no mundo real. São Paulo: Artmed, 2012.

GUIDDENS, Anthony. A constituição das sociedades. São Paulo: Martins Fontes, 2009.

GUIMARÃES, Raquel. Deficiência e cuidado: por que abordar gênero nessa relação? Revista Ser Social, v. 10, n. 22, 2008.

HABERMAS, Jurgen. Direito e democracia. Rio de Janeiro: Biblioteca Tempo Universitário, 1997. v. 1.

HALL, Peter A; TAYLOR, Rosemary C. R. As Três Versões do Neoinstitucionalismo. In Revista Lua Nova, n. 58, 2003. Disponível em: http://www.scielo.br/pdf/ln/n58/a10n58.pdf. Acesso em 2 de dezembro de 2008.

HARVEY, David. Condição pós-moderna: uma pesquisa sobre as origens da mudança cultural. 6. ed. São Paulo: Loyola, 1996.

HEIDTMANN NETO, Henrique. G. C. A sensibilidade territorial das políticas públicas: um estudo em comunidades ribeirinhas na Amazônia Legal. São Paulo, 2008.

HERRERA, Carlos Miguel. Estado, constituição e direitos sociais. In: NETO, Cláudia Pereira de Souza; SARMENTO, Daniel (org.). Direitos sociais: fundamentos, judicialização e direitos sociais em espécie. Rio de Janeiro: Lumen Juris, 2008.

HIRATA, Helena; GUIMARÃES, Nadya (org.). Cuidado e cuidadoras: as várias faces do trabalho do care. São Paulo: Atlas, 2012.

HOLANDA, Sérgio Buarque. Raízes do Brasil. São Paulo: Companhia das Letras, 1995. Publicado originalmente em 1936.

INSTITUTO DE PESQUISA ECONÔMICA APLICADA (IPEA). Políticas sociais: acompanhamento e análise. Brasília, 2006. (Edição Especial, 13). 
INSTITUTO NACIONAL DO SEGURO SOCIAL. Instrução Normativa n. 20 do Presidente do Instituto Nacional do Seguro Social, 20 de outubro de 2007. Disponível em: http://www.normaslegais.com.br/legislacao/ininss2_2007.htm. Acesso em 20 de setembro de 2014.

JUSTIÇA FEDERAL DA 4a REGIÃO. Composição da TRF 4. 2009. Disponível em: <http://www.trf4.jus.br/trf4/institucional/institucional.php?no=26>. Acesso em: 15 out. 2009.

KITTAY, Eva. Love's Labor: Essays on Women, Equality and Dependency. New York: Routledge, 1998.

KOLM, Serge-Christophe. Teorias modernas de justiça. São Paulo: Martins Fontes, 2000.

LEIVAS, Paulo Gilberto Cogo. Estrutura normativa dos direitos sociais fundamentais e o direito fundamental ao mínimo existencial. In: NETO, Cláudio Pereira de Souza; SARMENTO, Daniel (coord.). Direitos sociais: fundamentos, judicialização e direitos sociais em espécie. Rio de Janeiro: Lumen Juris, 2008.

LINHARES, Maria Yedda (org.). História geral do Brasil. Rio de Janeiro: Campus, 2011.

LINS, Cilene. Família e assistência social: análise dos governos FHC e Lula. 175 f. Tese (Doutorado em Política Social) — Universidade de Brasília, Brasília, 2013.

LOBO, Lilia Ferreira. Os infames da história: pobres, escravos e deficientes no Brasil. Rio de Janeiro: Lamparina, 2008.

MACHADO, Roberto et al. Danação da norma: a medicina social e constituição da psiquiatria no Brasil. Rio de Janeiro: Graal, 1978.

MAFFETTONE, Sebastiano; VECA, Salvatore (org.). A ideia de justiça de Platão a Rawls. São Paulo: Martins Fontes, 2005.

MARX, Karl. Ideologia alemã. São Paulo: Boitempo, 2004. Publicado originalmente em 1834.

MARTINS, Rita de Cássia Andrade. Cooperativas sociais no Brasil: debates e práticas na tecitura de um campo em construção. Dissertação de Mestrado. Departamento de Sociologia da Universidade de Brasília. Brasília, 2009.

MATTA, Gustavo Corrêa; MOROSINI, Márcia. Dicionário da educação profissional em saúde. Disponível em <http://www.epsjv.fiocruz.br/dicionario/verbetes/atesau.html>. Acesso em 20 de outubro de 2014.

MECLER, Kátia. Periculosidade: evolução e aplicação do conceito. Revista Brasileira de Crescimento e Desenvolvimento Humano, v. 20, n. 1, 2010. Disponível em: <http://pepsic.bvsalud.org/scielo.php?pid=S0104-12822010000100010\&script=sci_arttext $>$. Acesso em: 3 dez. 2014.

MEDEIROS, Marcelo; BRITTO, Tatiana; SOARES, Fábio. Programas focalizados de transferência de renda no Brasil: contribuições para o debate. Brasília: Ipea, 2007. (Texto 
para Discussão, 1283). Disponível em: 〈http://www.ipea.gov.br/default.jsp〉. Acesso em: 2 dez. 2008.

MENDONÇA, Eduardo. Da faculdade de gastar ao dever de agir: o esvaziamento contramajoritário de políticas públicas. In: NETO, Cláudio Pereira de Souza; SARMENTO, Daniel (coord.). Direitos sociais: fundamentos, judicialização e direitos sociais em espécie. Rio de Janeiro: Lumen Juris, 2008.

MINAS GERAIS. Programa de Atenção Integral ao Paciente Judiciário - PAI-PJ. Belo Horizonte, 2014. Disponível em: <http://ftp.tjmg.jus.br/presidencia/projetonovosrumos/pai_pj/>. Acesso em: 26 out. 2014.

MIOTO, Regina Celia Tamaso; CAMPOS, Marta Silva. Política de assistência social e a posição da família na política social brasileira. Ser Social, Brasília, v. 12, n. 1, p. 165-190, 2003.

MIOTO, Regina Celia Tamaso; LIMA, Telma Cristiane Sasso. Quem cobre as insuficiências das políticas públicas? Contribuição ao debate da família na provisão do bem-estar social. Revista de Políticas Públicas, v. 10, p. 165-185, 2006.

MONTAÑO, Carlos. Terceiro setor e questão social: crítica ao padrão emergente de intervenção social. São Paulo: Cortez, 2002.

MOREIRA, Juliano; PEIXOTO, Afrânio Revista Latino Americana de Psicopatologia Fundamental, ano IV, n. 2, p. 134-167, 2001. Publicado originalmente em 1904.

MÜLLER, Pierre; SUREL, Yves. A análise das políticas públicas. Pelotas: Educat, 2002.

NUSSBAUM, Martha. Las fronteras de la justicia. Madrid: Paidós, 2006. Las mujeres y el desarollo humano. Barcelona: Herder, 2000.

OS ESQUECIDOS. Direção: Luis Buñuel. Cidade do México, 1950. 91 min., preto e branco.

OSÓRIO, Rafael Guerreiro. A desigualdade racial de renda no Brasil: 1976-2006. Tese (Doutorado em Sociologia) — Universidade de Brasília, Brasília, 2009.

OUTHWAITE, William. The future of society. Oxford: BlackWell, 2006.

PENALVA, Janaína. $O$ direito à singularidade do portador de sofrimento mental: uma análise da Lei n ${ }^{\circ}$ 10.216/2001 à luz da Integridade do Direito. Dissertação (Mestrado em Direito) Universidade de Brasília, Brasília, 2007.

PENALVA, Janaína; DINIZ, Debora; MEDEIROS, Marcelo. O Benefício de Prestação Continuada no Supremo Tribunal Federal. Sociedade e Estado, v. 25, n. 1, p. 53-70, 2010.

PEREIRA, Potyara A. A assistência social prevista na Constituição de 1988 e operacionalizada pelas PNAS e pelo SUAS. Ser Social, n. 20, p. 63-83, jan./jun. 2007.

A assistência social na perspectiva dos direitos: crítica aos padrões dominantes de 
proteção aos pobres no Brasil. Brasília: Thesaurus, 1996.

A intersetorialidade das políticas sociais na perspectiva dialética. In: MONNERAT, Giselle; ALMEIDA, Ney Luiz Teixeira; SOUZA, Rosimary Gonçalves. A intersetorialidade na agenda das políticas sociais. Campinas: Papel Social, 2014.

Mudanças estruturais, política social e papel da família: crítica ao pluralismo de bemestar. In: MIONE, Apolinário; MATOS, Maurilio Castro de; LEAL, Maria Cristina (org.). Política social, família e juventude: uma questão de direitos. 2. ed. São Paulo: Cortez, 2006a.

Necessidades humanas: subsídios à crítica aos mínimos sociais. 3. ed. São Paulo: Cortez, 2006b.

Política social: temas e questões. São Paulo: Cortez, 2008.

PERES, Maria Fernanda T.; NERY FILHO, Antônio. A doença mental no direito penal brasileiro: inimputabilidade, irresponsabilidade, periculosidade e medida de segurança. História, Ciência, Saúde - Manguinhos, v. 9, n. 2, p. 335-355, 2002.

PERISSINOTTO, Renato. Marxismo e ciência social: um balanço crítico do marxismo analítico. Revista Brasileira de Ciências Sociais, v. 25, n.73, p. 113-128, 2010.

PESQUISA NACIONAL POR AMOSTRA DE DOMICÍLIO (PNAD) 2009: primeiros resultados. Situação da educação brasileira: avanços e problemas, Comunicado do IPEA. Brasília, 2010.

PORTOCARRERO, Vera. Arquivos da loucura: Juliano Moreira e a descontinuidade histórica da psiquiatria. Rio de Janeiro: Fiocruz, 2002.

PRADO, Geraldo Luiz Mascarenhas. Prisão: para quê e para quem? Diagnóstico do sistema carcerário e perfil do preso. Brasília: Ministério da Justiça, 2012. (Relatório Pensando o Direito). Disponível em: <http://participacao.mj.gov.br/pensandoodireito/wpcontent/uploads/2013/02/Volume-44-Relat\%C3\%B3rio-final.pdf $>$. Acesso em: 20 set. 2014.

PRINZ, Christopher. European Disability Pension Policies. Viena: Asgate, 2003.

PULIDO, Carlos Bernal. Fundamento, conceito e estrutura dos direitos sociais: uma crítica a "Existem direitos sociais?" de Fernando Atria. In: NETO, Cláudio Pereira de Souza; SARMENTO, Daniel (coord.). Direitos sociais: fundamentos, judicialização e direitos sociais em espécie. Rio de Janeiro: Lumen Juris, 2008.

REIS, Carlos Nelson; PESTANO, Cíntia Ribes. A especificidade da assistência social: algumas notas reflexivas. Textos \& Contextos, v. 5, n. 1, 2006.

RIOS, Roger Raupp; SANTOS, Wederson. Diversidade sexual, educação e sociedade: reflexões a partir do Programa Nacional do Livro Didático. Revista Psicologia Política, v. 8, p. 325-344, 2008.

ROBERT, Philippe. Sociologia do crime. Petropólis: Vozes, 2007. 
ROCHA, Carlos Vasconcelos. Neoinstitucionalismo como modelo de análise para políticas públicas. CIVITAS - Revista de Ciências Sociais, v. 5, n. 1, jan-jun, 2005. Disponível em: <http://revistaseletronicas.pucrs.br/ojs/index.php/civitas/article/view/32/1604>. Acesso em: 2 dez. 2008.

ROEMER, John E. Methodological individualism and deductive marxism. Theory and Society, v. 11, n. 4, p. 513-520, 1982.

RUSCHE, Georg; KIRCHHEIMER, Otto. Punição e estrutura social. Tradução de Gizlene Neder. Rio de Janeiro: Freitas Bastos, 1999.

SANTIAGO, Marina Agra. Panorama da saúde mental no Distrito Federal de 1987 a 2007: um estudo exploratório sobre a reforma psiquiátrica no DF. Dissertação (Mestrado em Psicologia) — Universidade de Brasília, Brasília, 2009.

SANTOS, Wanderley Guilherme dos. Cidadania e justiça: a política social na ordem brasileira. Rio de Janeiro: Campos, 1979.

SANTOS, Wederson. Deficiência e BPC: o que muda na vida das pessoas atendidas? Ciência e Saúde Coletiva, 2008. Disponível em: <http://www.abrasco.org.br/cienciaesaudecoletiva/artigos/artigo_int.php?id_artigo=3011>.

Acesso em: 2 dez. 2008.

Deficiência e democracia: a interpretação do Poder Judiciário sobre o Benefício de Prestação Continuada. Dissertação (Mestrado em Política Social) — Universidade de Brasília, Brasília, 2009.

Justiça e deficiência: a visão do Poder Judiciário sobre o BPC. Revista Sociedade em Debate, Pelotas, v. 12, n. 2, p. 165-186, 2006.

O que é incapacidade para a proteção social brasileira: o Benefício de Prestação Continuada e a deficiência. Argumentum, Vitória, v. 2, p. 116-132, 2010.

SARMENTO, Daniel. A proteção social dos direitos sociais: alguns parâmetros éticojurídicos. In: NETO, Cláudio Pereira de Souza; SARMENTO, Daniel (coord.). Direitos sociais: fundamentos, judicialização e direitos sociais em espécie. Rio de Janeiro: Lumen Juris, 2008.

SCHWARTZMAN, Simon. A Igreja e o Estado Novo: o Estatuto da Família. Cadernos de Pesquisa, v. 37, maio 1980.

SEN, Amartya. Desenvolvimento como liberdade. Tradução de Laura Teixeira Motta. São Paulo: Companhia das Letras, 2000.

Record, 2001.

Desigualdade reexaminada. Tradução de Ricardo Doninelli Mendes. Rio de Janeiro:

SILVA, Maria Lúcia Lopes. (Des)estruturação do trabalho e condições para a universalização da previdência social no Brasil. Tese (Doutorado em Política Social) - 
Universidade de Brasília, Brasília, 2011.

SILVA, Maria Ozanira da Silva e; YAZBEK, Maria Carmelita; DI GIOVANNI, Geraldo. A política brasileira no século XXI: a prevalência dos programas de transferência de renda. São Paulo: Cortez, 2004.

SILVA, Martinho Braga Batista. O desafio colocado pelas pessoas em medida de segurança no âmbito do Sistema Único de Saúde: a experiência do Paili-GO. Physis, v. 20, n. 2, p. 653 $682,2010$.

SOARES, Fabio; SOARES, Sergei; MEDEIROS, Marcelo; OSÓRIO, Rafael G. Programas de transferência de renda no Brasil: impactos sobre a desigualdade. Brasília: Ipea, 2006. (Texto para Discussão, 1228).

SOARES, Ilka de Araújo. Institucionalização da loucura: um recorte histórico sobre o município de Barbacena/MG. Rio de Janeiro: Fundação Biblioteca Nacional, 2006.

SORJ, Bila; FONTES, Adriana. O care como um regime estratificado: implicações de gênero e classe social. In: HIRATA, Helena; GUIMARÃES, Nadya (org.). Cuidado e cuidadoras: as várias faces do trabalho do care. São Paulo: Atlas, 2012.

SOUZA, José Moreira de; CARNEIRO, Ricardo. Universalismo e focalização na política de atenção à pessoa com deficiência. Saúde e Sociedade, v. 16, n. 3, p. 69-84, 2007.

SPOSATI, Adaílza (org.). Proteção social de cidadania: inclusão de idosos e pessoas com deficiência no Brasil, França e Portugal. São Paulo: Cortez, 2004.

SPOSATI, Adaílza et al. A assistência na trajetória das políticas sociais brasileiras. São Paulo: Cortez, 1985.

STAKE, Robert. Case studies. In: DENZIN, Norman; LINCOLN, Yvonna. Handbook of Qualitative Research. Thousand Oaks: Sage, 1994.

STRAUSS, Anselm; CORBIN, Juliet. Pesquisa qualitativa: técnicas e procedimentos para o desenvolvimento de teoria fundamentada. 2. ed. Porto Alegre: Artmed; Bookman, 2008.

SUNKEL, Guilhermo. El papel de la família en la protección social en América Latina. Santiago de Chile: 2006. (Série CEPAL, 120).

SUPREMO TRIBUNAL FEDERAL. ADI 1232, sobre o Benefício de Prestação Continuada. Brasília, $1999 . \quad$ Disponível em: <http://www.stf.jus.br/portal/peticaoInicial/pesquisarPeticaoInicial.asp>. Acesso em: 2 dez. 2008.

Repercussão Geral - Benefício assistencial de prestação continuada - idoso - renda per capita inferior a meio salário mínimo em 2007. Brasília, 2013. Disponível em: <http://www.stf.jus.br/portal/jurisprudencia/jurisprudenciaRepercussao.asp>. Acesso em: 2 dez. 2008.

TAVARES, Marcelo Leonardo. Assistência social. In: NETO, Cláudio Pereira de Souza; 
SARMENTO, Daniel (coord.). Direitos sociais: fundamentos, judicialização e direitos sociais em espécie. Porto Alegre: Lumen Juris, 2008.

TORRES, Ricardo Lobo. O mínimo existencial como conteúdo essencial dos direitos fundamentais. In: NETO, Cláudio Pereira de Souza; SARMENTO, Daniel (coord.). Direitos sociais: fundamentos, judicialização e direitos sociais em espécie. Porto Alegre: Lumen Juris, 2008.

VAITSMAN, Jeni; ANDRADE, Gabriela Rieveres Borges de; FARIAS, Luis Otávio. Proteção social no Brasil: o que mudou na assistência social após a Constituição de 1988. Ciência e Saúde Coletiva, v. 14, n. 3, p. 731-741, 2009.

VEYNE, Paul. Foucault: seu pensamento, sua pessoa. Rio de Janeiro: Civilização Brasileira, 2011.

YIN, Robert K. Estudo de caso: planejamento e métodos. Tradução de Daniel Grassi. 3. ed. Porto Alegre: Bookman, 2005.

ZGIET, Jamila. A reforma psiquiátrica no Distrito Federal: um estudo de caso sobre os principais obstáculos ao processo de implantação. Dissertação (Mestrado em Política Social) — Universidade de Brasília, Brasília, 2010.

WEBER, Max. Economia e sociedade. Brasília: Editora da UnB, 2000. v. 1. 


\section{APÊNDICES \\ APÊNDICES A \\ QUESTIONÁRIO EQUIPE PSICOSSOCIAL VEP}

Prezado(a),

você está sendo convidado a responder as perguntas abaixo como parte de um estudo que compõe a pesquisa de Doutorado em Sociologia, do assistente social Wederson Rufino dos Santos. A referida pesquisa teve diferentes técnicas de levantamento de dados em Estabelecimentos de Custódia e Tratamento Psiquiátrico no Brasil, dentre eles, um estudo documental analisou processos de medidas de segurança em fase de desinternação e de medidas extintas desta Vara de Execuções Penais - VEP, no ano de 2013 e início de 2014. O questionário abaixo é para complementar as informações da pesquisa realizada entre o final de 2013 e início de 2014 nesta VEP. Gostaria de contar com sua importante colaboração para a finalização do trabalho nesta VEP. As perguntas podem ser respondidas e devolvidas por correio eletrônico. $\mathrm{O}$ seu sigilo e sua confidencialidade serão preservados em todas as fases de análise e divulgação dos dados. Assim que o estudo for concluído, o pesquisador responsável se compromete a devolver os resultados à VEP.

Atenciosamente,

Wederson Rufino dos Santos

1. Quais os procedimentos e a rotina adotados na Seção Psicossocial para o momento da desinternação condicional dos indivíduos em medidas de segurança?

2. Como é o trabalho da Seção Psicossocial da VEP com a rede de saúde mental, como Centros de Atenção Psicossocial - CAPS, Casas de Passagens, Serviços Residenciais Terapêuticos, clínicas psiquiátricas no território onde o paciente em desinternação condicional passará a morar? É pré-requisito ter tais equipamentos para a desinternação ocorrer?

3. Como é o trabalho da Seção Psicossocial da VEP com a rede socioassistencial, como Centros de Referência de Assistência Social - CRAS, Centros de Referência Especializados - CREAS, Abrigos Públicos no território onde o paciente em desinternação condicional passará a morar? É pré-requisito ter tais equipamentos para a desinternação ocorrer?

4. A Seção Psicossocial da VEP faz algum tipo de trabalho que viabilize o acesso dos pacientes em medidas de segurança aos benefícios assistenciais como o Benefício de Prestação Continuada, o Bolsa-Família ou o auxílio reabilitação psicossocial do Programa de Volta para Casa?

5. Como é o trabalho com a família dos pacientes em medidas de segurança no momento da desinternação? Quais são os principais desafios no trabalho com a família no momento da desinternação dos pacientes em medidas de segurança?

6. Se o paciente não tem contato com a família ou os laços são fragilizados ou inexistentes, isso é motivo para não desinternação? Quais os procedimentos para superar tal situação?

7. Como vocês avaliam o alcance das atividades desempenhadas pela VEP para potencializar a desinternação dos pacientes em medidas de segurança? 
8. Na fase anterior desta pesquisa, foram analisados os processos das medidas de segurança em desinternação e das medidas de segurança extintas em 2013. Pode ser verificado que, em média, o paciente fica entre 4 e 5 anos internado em medida de segurança na ATP-DF. Claro que há as discrepâncias, mas este é um período médio. Depois, entre a cessação da periculosidade e a desinternação, este período é curto, em torno de 2 meses? O que faz com que o período entre a prisão e a sentença de desinternação seja, em média, mais longo e entre a cessação e a desinternação seja, em média, mais curto? Há algum tipo de trabalho de preparo para a desinternação do indivíduo, antes da sentença de desinternação ser determinada? Quando a Seção Psicossocial da VEP começa a atuar para facilitar a desinternação, antes aou depois da sentença de desinternação?

9. Na fase da pesquisa anterior, e em outros estudos, é possível verificar várias características que indicam vulnerabilidades sociais dos pacientes em medidas de segurança, como baixa escolaridade, pobreza, falta de formação profissional e técnica. Na sua opinião e experiência, essas características podem ter influência para a fase da desinternação dos indivíduos?

10. Gostaria de acrescentar algum comentário ou abordar algum aspecto que não foi abordado? 


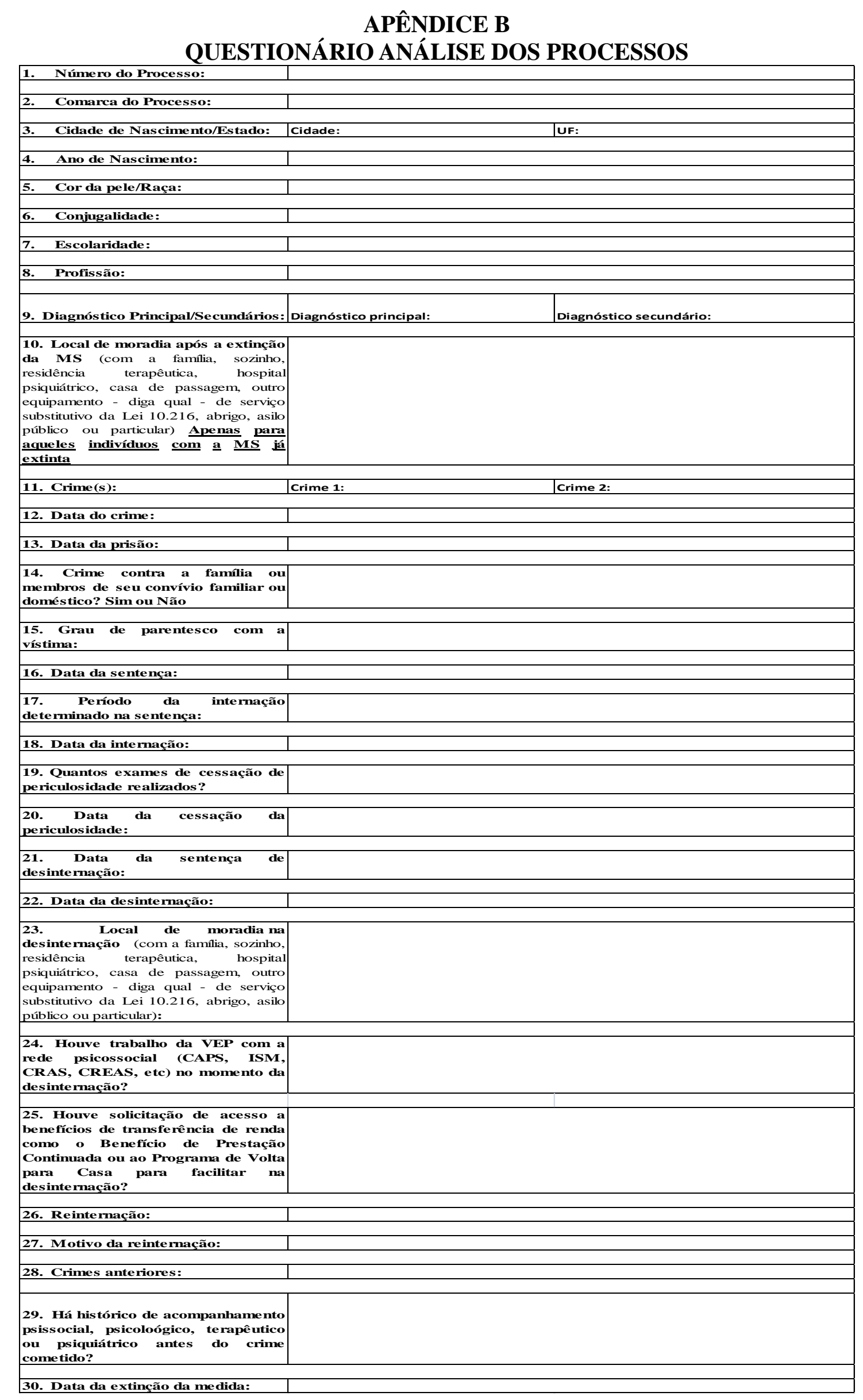




\section{APÊNDICE C \\ DECLARAÇÃO PARA ENTRADA EM CAMPO NA VEP-DF}

Eu, Maria Stela Grossi Porto, declaro para os devidos fins que sou orientadora de doutorado de Wederson Rufino dos Santos, matrícula 10/0022570, do Departamento de Sociologia da Universidade de Brasília (SOL-UnB). Wederson tem como projeto de pesquisa o seguinte estudo "Os esquecidos: crime, família e assistência na inimputabilidade por doença e deficiência mental no Brasil”. Parte do levantamento de dados da pesquisa se constituirá em um estudo qualitativo do tipo análise documental de processos sob guarda da Vara de Execuções Penais (VEP), do Tribunal de Justiça do Distrito Federal e Territórios (TJDFT). Os processos são de Medidas de Segurança dos indivíduos que estiveram em desinternação condicional nos anos de 2011 e 2012 no Distrito Federal. Essa autorização inicial constitui exigência do Comitê de Ética em Pesquisa do Instituto de Ciências Humanas da Universidade de Brasília (CEP-IH). Após a aprovação do CEP, o parecer será enviado a essa VEP no intuito de dar os demais encaminhamentos para autorização e início da pesquisa.

A pesquisa de doutorado tem como objetivo analisar como funcionam as políticas de assistência social e dos serviços substitutivos de saúde mental no momento da desinternação condicional dos indivíduos em medidas de segurança, na interface com a política de segurança pública. O estudo possui várias fases de coleta de dados, das quais uma delas consiste na análise de processos judiciais dos internos da Ala de Tratamento Psiquiátrico (ATP), localizada no Presídio Feminino do Distrito Federal, em cumprimento de medida de segurança e que estiveram em processo de desinternação condicional nos anos de 2011 e 2012. Portanto, a unidade de análise do estudo relacionado à VEP-DF são os indivíduos em medidas de segurança que após cessação da periculosidade foram submetidos à desinternação condicional nos dois anos escolhidos. Essa fase do estudo é de cunho inteiramente documental e não entrará em contato direto com os indivíduos, portanto, não haverá entrevistas com os indivíduos.

A pesquisa será feita no arquivo sob guarda da VEP e será realizada a depender da disposição de local e horários da própria Vara. Uma segunda fase do estudo prevê entrevistas com profissionais da VEP, como juiz, psicólogos e assistentes sociais, que atuam na fase de desinternação dos indivíduos em medidas de segurança. Essa fase também será realizada a depender da disposição de local, horário e concordância dos profissionais que se sentirem à vontade em participar. O pesquisador responsável pelo estudo garantirá o sigilo e confidencialidade das informações em todas as fases da pesquisa e garantirá que nenhuma informação que identifique os sujeitos participantes envolvidos no estudo será divulgada. Atenciosamente,

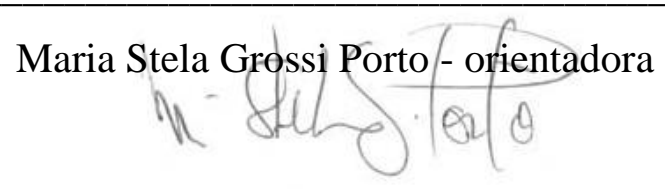

